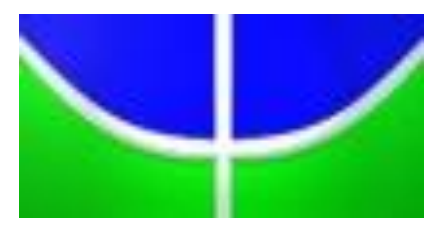

Universidade de Brasília

Instituto de Letras

Departamento de Linguística, Português e Línguas Clássicas

Programa de Pós-Graduação em Linguística

ALTERNÂNCIA NÓS E A GENTE NO PORTUGUÊS BRASILEIRO E NO PORTUGUÊS URUGUAIO DA FRONTEIRA BRASIL-URUGUAI (ACEGUÁ)

CÍNTIA DA SILVA PACHECO

Brasília - DF

Dezembro - 2014 


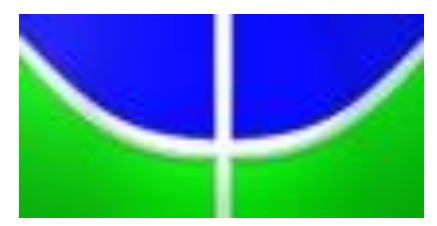

Universidade de Brasília

Instituto de Letras

Departamento de Linguística, Português e Línguas Clássicas

Programa de Pós-Graduação em Linguística

\author{
CÍNTIA DA SILVA PACHECO
}

ALTERNÂNCIA NóS E $A$ GENTE NO PORTUGUÊS BRASILEIRO E NO

PORTUGUÊS URUGUAIO DA FRONTEIRA BRASIL-URUGUAI (ACEGUÁ)

Tese apresentada ao Programa de Pósgraduação em Linguística, Português e Línguas Clássicas, Instituto de Letras, Universidade de Brasília, como requisito parcial para obtenção do título de Doutor em Linguística, na área de concentração Linguagem e Sociedade.

Orientadora: Profa. Dra. Maria Marta Pereira Scherre (UnB/UFES)

Co-orientadora: Profa. Dra. Ana Maria Carvalho (Universidade do Arizona)

\footnotetext{
Brasília - DF

Dezembro - 2014
} 


\title{
ALTERNÂNCIA NóS E A GENTE NO PORTUGUÊS BRASILEIRO E NO PORTUGUÊS URUGUAIO DA FRONTEIRA BRASIL-URUGUAI (ACEGUÁ)
}

\author{
CÍNTIA DA SILVA PACHECO
}

\section{BANCA EXAMINADORA}

Profa. Dra. Maria Marta Pereira Scherre - UnB/UFES

(Orientadora e Presidente da Banca)

Profa. Dra. Lilian Coutinho Yacovenco - UFES

(Membro externo)

Prof. Dra. Caroline Rodrigues Cardoso - UNILAB

(Membro externo)

Prof. Dra. Ana Adelina Lopo Ramos - UnB

(Membro interno)

Prof. Dra. Ulisdete Rodrigues de Souza Rodrigues - UnB

(Membro interno)

Prof. Dra. Heloisa Maria Moreira Lima Salles - UnB

(Membro suplente) 
Ao meu filho Arthur, razão de todo o meu esforço. Ao Márcio, grande parceiro de vida. A minha avó, meu eterno exemplo. 


\section{Minga Blanco \\ (Morador de Aceguá)}

\section{Parceiro}

Encilhe ao clarear do dia E bote o pingo na estrada, Empreenda logo a jornada

No rumo do aceguá...

Pois aqui encontrará

Todo povo reunido,

Tomando mate aquecido

Na beira de algum fogão,

Revivendo a tradição

Do nosso pago querido.

Escutará algum cantor

Que cante por todos nós

As cantigas dos avós,

Dos tempos do pastoreio,

Das paradas de rodeio,

Dos repontes e tropeadas

E das sangrentas topadas aonde

Muitos tombaram

E para o mundo mostraram

A força da gauchada

Aqui sentira pulsar

O coração deste povo,

Que se reúne de novo

Entre cavalos e cantos

Para reforçar os encantos

Que nos prenderam as coxilhas...

Aqui viveram as famílias

É o nosso jeito de ser

$\mathrm{E}$ assim queremos viver a

Semana farroupilha. 


\section{Jorge Drexler \\ (Cantor e compositor uruguaio)}

Frontera

Yo no sé de dónde soy, mi casa está en la frontera (BIS)

Y las fronteras se mueven, como las banderas. (BIS)

Mi patria es un rinconcito, el canto de una cigarra. (BIS)

Los dos primeros acordes que yo supe en la guitarra (BIS)

Soy hijo de un forastero y de una estrella del alba, y si hay amor, me dijeron, y si hay amor, me dijeron, toda distancia se salva.

No tengo muchas verdades, prefiero no dar consejos. (BIS)

Cada cual por su camino, igual va a aprender de viejo. (BIS)

Que el mundo está como está por causa de las certezas (BIS)

La guerra y la vanidad comen en la misma mesa (BIS)

Soy hijo de un desterrado y de una flor de la tierra, $\mathrm{y}$ de chico me enseñaron las pocas cosas que sé del amor y de la guerra.

\section{Fronteira}

Eu não sei de onde sou, Minha casa está na fronteira (BIS)

$\mathrm{E}$ as fronteiras se movem, Como as bandeiras. (BIS)

Minha pátria é um cantinho, $\mathrm{O}$ canto de uma cigarra. (BIS)

Os dois primeiros acordes Que eu aprendi na guitarra (BIS)

Sou filho de um forasteiro E de uma estrela d'alva, E se há amor, me disseram, E se há amor, me disseram, Toda distância se salva.

Não tenho muitas verdades, Prefiro não dar conselhos. (BIS)

Cada um por seu caminho, Vai aprendendo com a idade. (BIS)

Que o mundo está como está Por causa das certezas (BIS)

A guerra e a vaidade Comem na mesma mesa (BIS)

Sou filho de um desterrado E de uma flor da terra, De menino me ensinaram As poucas coisas que eu sei Do amor e da guerra. 
A Deus, pelas bênçãos constantes que me concede e pela força para concluir mais uma grande etapa dos meus sonhos acadêmicos.

À professora e orientadora Marta Scherre, pelo exemplo de vida e de profissionalismo, e por ter aceitado mais uma vez ser minha parceira de pesquisa.

À professora e co-orientadora Ana Maria Carvalho, pelo constante apoio desde a realização do pré-projeto e em tudo que precisei durante o doutorado.

Ao professor Hildo Honório pela ajuda na escolha da comunidade e pelo incentivo para que eu fizesse a pesquisa de campo antes mesmo de submeter o projeto.

À banca da defesa Lilian Yacovenco, Caroline Cardoso, Ana Ramos, Ulisdete Souza e Heloisa Salles, pela disponibilidade em ler meu trabalho e manter sempre o diálogo aberto.

Aos meus amados mestres, que tanto me ensinaram e fizeram parte da construção significativa do meu "ser acadêmico", Cibele Brandão, Marcos Lunguinho, Deborah Cristina, Maria Luiza Coroa, Rozana Reigota, Hildo Couto, Dioney Gomes, Janaína Aquino, Rachel Dettoni, Antônio Augusto, Jane Adriana, Marcos Bagno, Marta Scherre. Entro na UnB aos 17 anos e saio agora aos 29 anos, certa de que trilhei o melhor caminho.

Ao meu País, que, por meio da Capes-Reuni, auxiliou-me financeiramente durante os quatro anos a fim de facilitar o andamento da pesquisa.

Ao departamento do PPGL- UnB, Viviane Resende, coordenadora de pósgraduação, Renata e Ângela, secretárias, pelo carinho com que sempre me trataram.

À minha avó, grande incentivadora dos meus estudos e apoiadora incondicional dos meus projetos, sobretudo, acadêmicos.

Ao meu pai, pela simplicidade e humildade que sempre estiveram presentes na minha vida.

Ao irmão Eduardo Pacheco, grande exemplo de garra e determinação.

Ao Márcio e sua mãe Maria, pelo olhar de compaixão e pela parceria ao longo de todos esses anos de vida familiar e acadêmica, sobretudo na época das pesquisas de campo e da coleta de dados, sempre ao meu lado.

À Carolina Andrade, pela parceria sociolinguística de oito anos e também pelo apoio na vida pessoal; 
À Elda Ivo, pela amizade, pelo empréstimo de materiais, em especial para o capítulo "Identidade sociolinguística na fronteira de Aceguá (Brasil-Uruguai)”, e pelos constantes votos de força.

Ao Idelso Espinosa Taset, pela ajuda nas traduções e pelo empréstimo de materiais sobre "interlíngua".

À Sandra Silva, Aline Mesquita, Dalmo Borges, Daisy Cardoso, Deborah Christina, Luiza Kuwae, Marcus Lunguinho, Rodrigo Albuquerque, Patrícia Tavares, Nivia Lucca, Fernanda Coutinho, pelo exemplo de seres humanos, professores e cientistas fantásticos.

Enfim, aos meus tios, primos, família e amigos, pela paciência e compreensão em tantos momentos de ausência.

Aos moradores de Aceguá, que tão bem me receberam durante as duas viagens. A todos vocês, agradeço pela confiança na pesquisa de tentar representar linguística e socialmente o que acontece na fronteira.

Em especial, a todos os cidadãos que lutam contra a desigualdade social e contra o preconceito social manifestado de diferentes formas e, principalmente, pela linguagem, aceitando que a diferença é inerente a todo ser humano e é o grande espetáculo da vida. 
O objetivo desta pesquisa é identificar e analisar a entrada do pronome a gente na comunidade bilíngue uruguaia em Aceguá (fronteira Brasil-Uruguai) e verificar se esse fenômeno constitui um elemento ratificador da variedade do português uruguaio da fronteira e se aproxima do português brasileiro da fronteira e do restante do Brasil. A hipótese principal é de que se trata de uma mudança linguística recente na variedade do português uruguaio, mesmo porque até então não havia registros de a gente como pronome, mas apenas como item lexical, semelhante ao que acontece no espanhol (ELIZAINCÍN 1987, p. 85). O marco teórico da pesquisa é a Teoria da Variação, proposta por Labov (1972), a Teoria da Mudança Linguística, desenvolvida por Weinreich, Labov e Herzog (1968), e o estudo sobre o contato linguístico do ponto de vista da variação linguística, que tem como precursoras Poplack (1993) e posteriormente Meyerhoff (2009). A análise quantitativa dos dados, obtidos por meio de entrevistas, é feita através do novo pacote de programas Goldvarb-X (SANKOFF, 1988; SANKOFF, TAGLIAMONTE \& SMITH, 2005). A análise é complementada com uma discussão sobre a identidade sociolinguística da fronteira a respeito da inserção do pronome a gente na comunidade uruguaia como sujeito discursivo sem ferir a identidade múltipla e fluida dos moradores da fronteira. $\mathrm{O}$ resultado estatístico indica que, no nível linguístico e social, o português brasileiro e o português uruguaio (sem os falantes categóricos de nós) são semelhantes quanto ao favorecimento do pronome sujeito a gente nos contextos de: (i) faixa etária jovem, (ii) sujeito explícito, (iii) referência genérica, (iv) dados de a gente precedidos de a gente, (v) tempo verbal do presente. A função sintática e a concordância verbal são analisadas apenas em percentagens, e o sexo não foi selecionado em nenhuma análise. $\mathrm{O}$ resultado aponta para uma diferença social e duas linguísticas. No primeiro caso, a análise uruguaia com todos os falantes mostra os adultos favorecendo o uso de a gente por questões de mobilidade social e pela existência de falantes categóricos. A diferença linguística está no tempo verbal, já que o pretérito perfeito sem neutralização favorece o uso de a gente na análise uruguaia e desfavorece na análise brasileira; e no tipo de referência, já que não é selecionada na análise uruguaia, mas é selecionada na análise brasileira. Portanto, os resultados obtidos apontam semelhanças e diferenças importantes nas duas comunidades de fala da fronteira Brasil-Uruguai, que as aproximam e as individualizam.

Palavras chaves: contato linguístico, português uruguaio, português brasileiro, pronome a gente, identidade sociolinguística. 
This research aims at identifying and analyzing the use of pronoun a gente in uruguayan bilingual community of Aceguá (Brazilian-Uruguayan border), as well as verifying whether this phenomenon ratifies the uruguayan portuguese variety spoken in the borderland, and if it closes on the brazilian portuguese spoken there and on the one used elsewhere in Brazil. The main hypotheses points at this phenomenon as a linguistic change in the uruguayan portuguese variety, considering that there were no previous records of the use of a gente as a pronoun, but only as a lexical item, resembling what happens in the Spanish case (ELIZAINCÍN 1987, p. 85). The theoretical framework of this investigation is made up by the Variation Theory (LABOV, 1972), The Linguistic Change Theory (WINREICH, LABOV \& HERZOG, 1968), and by the pioneer study of Poplack (1993) and more recent research of Meyerhoff (2009) on linguistic contact from the linguistic variation perspective. The quantitative analysis of data collected from interviews was made with the support of the newest Goldvarb-X program package (SANKOFF, 1988; SANKOFF, TAGLIAMONTE \& SMITH, 2005). This analysis includes a discussion on sociolinguistic identity in the borderland, mainly about the insertion of a gente pronoun as a discursive subject in the uruguayan community, without hurting the multiple and fluid identity of the borderland neighbors. The statistical result indicates that, on the linguistic and social level, the brazilian portuguese and the uruguayan portuguese (excluding the categorical users of nós) equally favors the use of a gente subject pronoun in contexts of: (i) youngsters age group, (ii) explicit subject, (iii) generic reference (iv) a gente data proceeded by a gente, and (v) present verbal tense. The syntactic function and the verbal concordance are analyzed only on their percentages, and gender was not chosen in any round. The result points at one social diference and two linguistic ones. In the first case, the uruguayan analysis with all of the participants shows adults preferring the use of $a$ gente due to social mobility and to the existence of categorical users. The linguistic differences have to do with the verbal tense because the perfect past without neutralization favors a gente in the uruguayan analysis, but not in the brazilian one, and with the type of reference, wich is not chosen in the uruguayan analysis, but in the brazilian one. Therefore, the results obtained indicate important similiarities and differences in the two speech communities of the Brazil-Uruguay, which approximates and individualizes them as well.

Key words: linguistic contact, uruguayan portuguese, brazilian portuguese, a gente pronoun, sociolinguistic identity. 
El objetivo de esta investigación es identificar y analizar la entrada del pronombre $a$ gente en la comunidad bilingüe uruguaya en Aceguá (frontera Brasil-Uruguay) y comprobar si ese fenómeno constituye un elemento ratificador de la variedad del portugués uruguayo de la frontera y se aproxima al portugués brasileño de esa zona y al del resto Brasil. La hipótesis principal ve ese fenómeno como un cambio lingüístico en la variedad del portugués uruguayo, porque no hay registros anteriores del uso de $a$ gente como pronombre, sino solamente como elemento lexical, algo semejante a lo que sucede en español (ELIZAINCÍN 1987, p. 85). El marco teórico de este estudio está integrado por la Teoría de la Variación, propuesta por Labov (1972), la Teoría del Cambio Linguístico, desarrollada por Weinreich, Labov y Herzog (1968), y el estudio pionero de Poplack (1993) sobre el contacto lingüístico desde la perspectiva de la variación lingüística, y la investigación posterior de Meyerhoff (2009) sobre ese asunto. El análisis cuantitativo de los datos recogidos por medio de entrevistas se hizo con el auxilio del nuevo paquete de programas Goldvarb-X (SANKOFF, 1988; SANKOFF, TAGLIAMONTE \& SMITH, 2005). Ese análisis se completa con una discusión acerca de la identidad sociolinguística en la frontera en relación con la inserción del pronombre $a$ gente en la comunidad uruguaya como sujeto discursivo sin menoscabar la identidad múltiple y fluida de los habitantes de la región fronteriza. El resultado estadístico indica que, en los niveles lingüístico y social, el portugués brasileño y el portugués uruguayo (excluyendo a los usuarios categóricos de nós) favorecen igualmente el uso del pronombre a gente en función de sujeto en los contextos de: (i) grupo etario joven, (ii) sujeto explícito, (iii) referencia genérica, (iv) datos de a gente precedidos de a gente, (v) tiempo verbal del presente. La función sintáctica y la concordancia verbal se analizan solo en porcentajes y el sexo no se seleccionó en ningun análisis. El resultado indica una diferencia social y dos lingüísticas. En el primer caso, el análisis uruguayo con todos los participantes muestra que prefieren el uso de $a$ gente en razón de la movilidad social y de la existencia usuarios categóricos. Las diferencias lingüísticas se localizan, por un lado, en el tiempo verbal, puesto que el pretérito perfecto sin neutralización favorece al pronombre a gente en el análisis uruguayo, pero no en el brasileño y, por otro, en el tipo de referencia, ya que esta no se selecciona en el análisis uruguayo, pero sí en el brasileño. Por lo tanto, los resultados obtenidos indican similitudes y diferencias importantes en las dos comunidades de habla de la frontera Brasil-Uruguay, que las aproximan y las individualizan.

Palabras claves: contacto lingüístico, portugués uruguayo, portugués brasileño, pronombre a gente, identidad sociolingüística. 
Figura 1: Escala de Elizaincín (1992, p. 68) sobre o continuum entre o português e o espanhol 
Foto 1: Placas sobre o Tratado de Limites 40

Foto 2: Último marco demarcatório em Aceguá

Foto 3: Praça localizada entre Brasil e Uruguai 41

Foto 4: Símbolos de Aceguá 44

Foto 5: Entrada de Aceguá $\quad 47$

Foto 6: O cavalo de pedra em Aceguá $\quad 54$

Foto 7: Semana Farroupilha na praça Caco Blanco em setembro de 2011

Foto 8: Piquetes da Semana Farroupilha de Aceguá em setembro de 2011

Foto 9: Símbolo de paz e união entre os povos e das placas do Uruguai e Brasil $\quad 57$ 
Mapa 1: Mapa de Aceguá 46

Mapa 2: Mapa da divisão distrital de Aceguá-Brasil 50

Mapa 3: Mapa da distribuição do pronome a gente no Brasil 250 
Quadro 1: Distribuição de nós, nosotros e a gente no espanhol, no português brasileiro e no português uruguaio 59

Quadro 2: Distribuição dos 38 colaboradores brasileiros e uruguaios 149

Quadro 3: Todas as variáveis sociais codificadas

Quadro 4: Todas as variáveis linguísticas codificadas

Quadro 5: Hierarquia da saliência segundo Naro et alii (1999, p. 203)

Quadro 6: Tempo verbal reinterpretado com base na neutralização segundo Naro et alii (2014, p. 10)

Quadro 7: Distribuição dos colaboradores uruguaios

Quadro 8: Distribuição dos colaboradores uruguaios entre a fala categórica em nós e a fala variável

Quadro 9: Distribuição dos colaboradores brasileiros 225

Quadro 10: Distribuição dos colaboradores brasileiros entre a fala categórica em nós e a fala variável

Quadro 11: Ordem de significância das variáveis sociais e linguísticas nas três análises 
Tabela 1: Percentagem global das variantes nós e a gente no português brasileiro e no português europeu

Tabela 2: Percentagem global das variantes nós e a gente na posição de sujeito do português brasileiro e do português uruguaio da amostra de Aceguá

Tabela 3: Efeito das variáveis sociais em relação ao pronome a gente no português brasileiro e no português uruguaio da amostra de Aceguá

199

Tabela 4: Efeito das variáveis linguísticas em relação ao pronome a gente no português brasileiro e no português uruguaio da amostra de Aceguá 206

Tabela 5: Percentagem global das variantes nós e a gente na posição de sujeito do português uruguaio da amostra de Aceguá

Tabela 6: Efeito das variáveis sociais em relação ao pronome a gente no português uruguaio da amostra de Aceguá

Tabela 7: Peso relativo da variável "sexo" em cada nível de significância do português uruguaio

Tabela 8: Percentagem de uso do pronome a gente na fala dos colaboradores uruguaios

Tabela 9: Efeito das variáveis linguísticas em relação ao pronome a gente no português uruguaio na amostra de Aceguá

Tabela 10: Percentagem global das variantes nós e a gente na posição de sujeito do português brasileiro da amostra de Aceguá

Tabela 11: Efeito das variáveis sociais em relação ao pronome a gente no português brasileiro da amostra de Aceguá

Tabela 12: Peso relativo da variável "sexo" em cada nível de significância do português brasileiro de Aceguá

228

Tabela 13: Percentagem de uso do pronome a gente na fala dos colaboradores brasileiros

Tabela 14: Efeito das variáveis linguísticas em relação ao pronome a gente no português brasileiro da amostra de Aceguá

Tabela 15: Percentagem global das variantes nós e a gente na posição de sujeito nas três análises

Tabela 16: Comparação das variáveis sociais e linguísticas nas três análises (com todos os dados) 
Tabela 17: Comparação das variáveis sociais e linguísticas nas três análises (sem os dados categóricos de nós)

Tabela 18: Comparação das variáveis sociais nas três análises com peso relativo (com todos os dados e sem os dados categóricos de nós)

Tabela 19: Comparação das variáveis linguísticas nas três análises com peso relativo (com todos os dados e sem os dados categóricos de nós)

Tabela 20: Comparação da variável função sintática nas três análises da amostra de Aceguá

Tabela 21: Nós e a gente na região Centro-Oeste

Tabela 22: Nós e a gente na região Sudeste 247-248

Tabela 23: Nós e a gente na região Sul 248

Tabela 24: Nós e a gente na região Nordeste 248

Tabela 25: Nós e a gente no português europeu

Tabela 26: Tipos de concordância de número no português brasileiro e no português uruguaio da amostra de Aceguá 


\section{CAPÍTULO 1 - ANTECEDENTES HISTÓRICOS E GEOGRÁFICOS DA FRONTEIRA}

BRASIL-URUGUAI

1.10 que é fronteira?

1.2 A história da fronteira luso-espanhola na América ...................................................31

1.3 A comunidade de Aceguá ……………………………………………………………....46

\section{CAPÍTULO 2 - CONTATO LINGUÍSTICO NA FRONTEIRA DE ACEGUÁ (BRASIL-} URUGUAI)

2.1 Precursores dos estudos sobre contato linguístico na fronteira Brasil-Uruguai 62

2.2 Como definir o falar da fronteira? .................................................................................. 78

2.2.1 Dialeto misto, fronterizo e pidgin .................................................................... 79

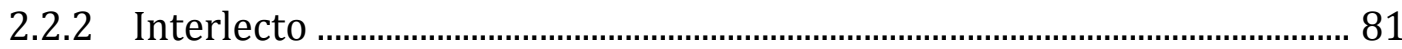

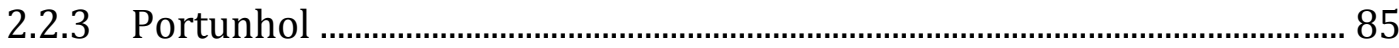

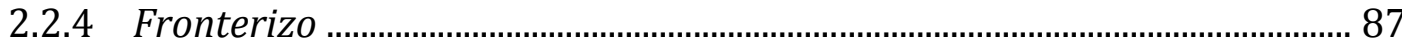

2.2.5 DPU (Dialetos Portugueses do Uruguai) e pré-pidgin ................................. 88

2.2.6 PU (Português Uruguaio) ................................................................................ 91

2.3 Fenômenos linguísticos comuns aos falantes brasileiros monolíngues e aos falantes uruguaios bilíngues de Aceguá ………………………………………………... 93

2.4 Consequências do contato linguístico ………………………………………………... 95

2.4.1 Empréstimo lexical .............................................................................................. 96

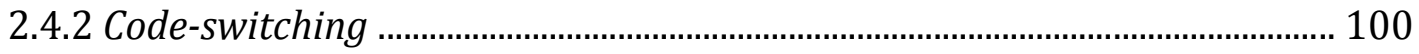

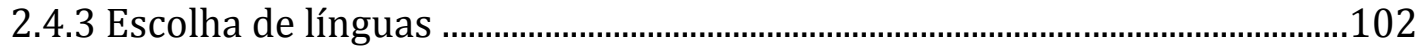




\section{CAPÍTULO 3 - A DIACRONIA E A SINCRONIA DOS PRONOMES DE PRIMEIRA}

PESSOA DO PLURAL

3.1 Nós e a gente no latim, português arcaico e em línguas românicas ...................... 106

3.2 Nós e a gente nas gramáticas tradicionais .................................................................. 112

3.3 Nós e a gente nas gramáticas descritivas e na gramaticalização........................... 114

3.4 Nós e a gente no português brasileiro e no português europeu ........................... 118

\section{CAPÍTULO 4 - PRESSUPOSTOS TEÓRICOS E PROCEDIMENTOS METODOLÓGICOS DA PESQUISA

4.1 Teoria da Variação e da Mudança Linguística ............................................................. 124

4.2 A variável sintática e suas implicações .................................................................... 131

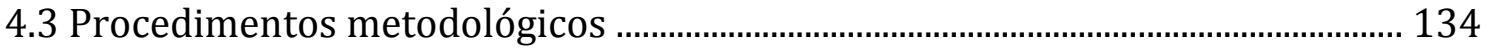

4.3.1 Aspectos quantitativos e qualitativos ............................................................ 134

4.3.2 A pesquisa de campo ……............................................................................. 143

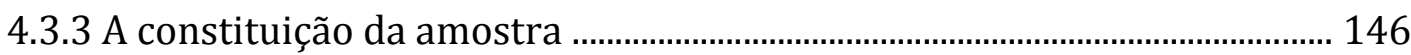

4.3.4 A variação de nós e a gente na fronteira ....................................................... 150

4.3.5 A constituição da variável dependente e das variáveis independentes 155

CAPÍTULO 5 - VARIAÇÃO PRONOMINAL NÓS E A GENTE ..................................... 164

5.1 Hipóteses e exemplos das variáveis sociais .............................................................. 164

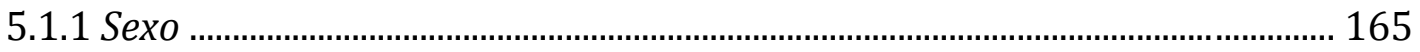

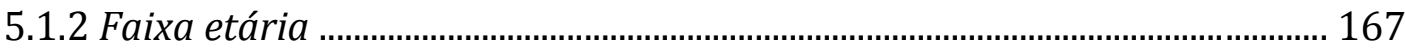

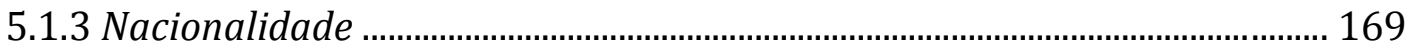

5.1.4 Grau de escolaridade ..................................................................................... 171

5.1.5 Identificação do colaborador ...................................................................... 171

5.2 Hipóteses e exemplos das variáveis linguísticas ......................................................... 172

5.2.1 Preenchimento do sujeito .................................................................................. 173

5.2.2 Paralelismo linguístico ...........................................................................................177

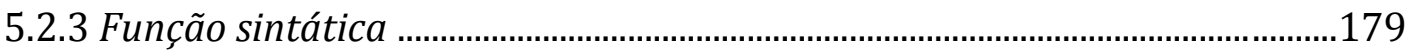

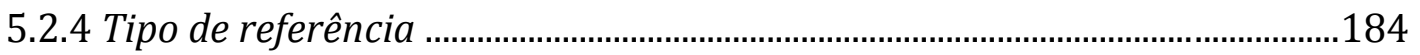


5.2.5 Tempo verbal 190

5.3 Análise conjunta dos resultados de brasileiros e uruguaios 197

5.3.1 Variáveis sociais 199

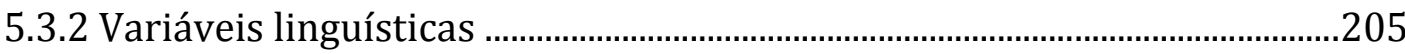

5.4 Análise dos resultados apenas dos uruguaios .............................................................. 211

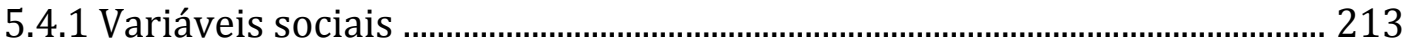

5.4.2 Variáveis linguísticas ........................................................................................222

5.5 Análise dos resultados apenas dos brasileiros …....................................................225

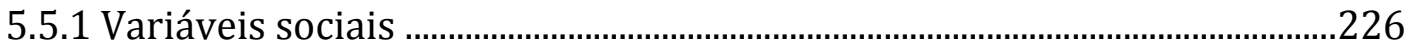

5.5.2 Variáveis linguísticas .................................................................................231

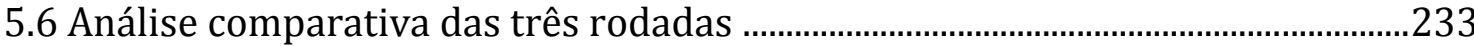

5.7 Variação na concordância de número no sintagma verbal ..................................... 251

CAPÍTULO 6 - IDENTIDADE SOCIOLINGUÍSTICA NA FRONTEIRA DE ACEGUÁ

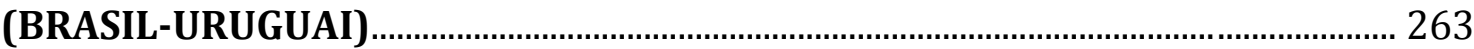

6.1 As identidades, os territórios e a Ecolinguística ....................................................... 266

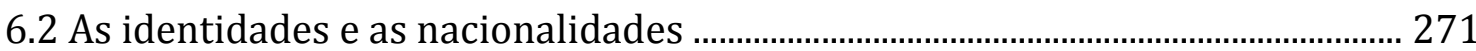

6.3 As identidades e as diferenças ................................................................................ 273

6.4 As identidades e a pós-modernidade ...................................................................... 276

6.5 As identidades discursivas e os significados sociais das variantes .................... 279

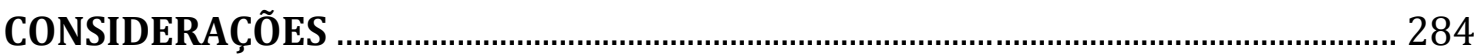

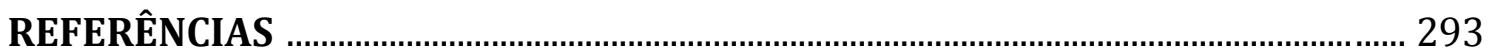

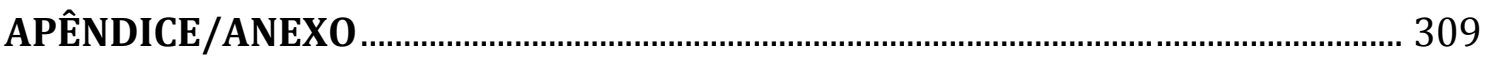

Apêndice I - Termo de Consentimento Livre e Esclarecido (TCLE) ............................ 309

Anexo I - Aprovação do comitê de ética …………................................................................ 311 
$\mathrm{O}$ interesse em pesquisar o português falado em ambos os lados da fronteira Brasil-Uruguai surgiu ainda no mestrado quando participei do VI Congresso Internacional da ABRALIN de João Pessoa, em março de 2009, e conheci a professora Ana Maria Carvalho, da Universidade do Arizona. Nessa ocasião, fiz seu minicurso sobre "Padrões Sociolinguísticos em Contextos de Línguas de Contato".

Foi na descoberta dos estudos de português de contato na fronteira que encontrei uma maneira de unir minhas duas áreas de formação acadêmica: Letras-Português e Letras-Espanhol. Como sempre quis fazer um estudo que envolvesse o português e o espanhol, foi uma oportunidade para que eu já pensasse em um projeto com essa configuração. Além disso, sempre foi meu objetivo trabalhar com as minorias linguísticas, especialmente em situações bem variáveis, por levar em consideração duas línguas (português e espanhol) e as variações existentes em cada uma delas.

Acredito que as ciências e, sobretudo, a Linguística, muito têm a contribuir para revelar as situações sociolinguísticas vivenciadas pelos povos e, na voz dos linguistas, ajudar a legitimar, mesmo que indiretamente, os modos de comunicação existentes.

Logo depois do minicurso, em abril de 2009, cursei a disciplina Seminário de Pesquisa do Programa de Pós-Graduação em Linguística da UnB e assisti a uma palestra do professor Hildo Honório intitulada "Contato português-espanhol na fronteira BrasilUruguai: Chuí/Chuy".

Assim, ainda no último ano do mestrado, em 2009 (14/10/09 a 19/10/09), decidi fazer o pré-projeto para o doutorado. O professor Hildo Honório foi quem sugeriu que eu estudasse a fronteira Aceguá/Aceguá, uma vez que essa localidade ainda não havia sido analisada do ponto de vista linguístico, e já fizesse a pesquisa de campo antes mesmo de submeter o projeto ao Departamento de Linguística.

Naquela ocasião, tive os primeiros contatos com a fronteira e as primeiras informações documentais por meio dos escritos encontrados com moradores, bibliotecas e prefeitura. Assim, comecei as entrevistas apenas com os brasileiros e fui ampliando minhas redes sociais até a volta em 2011.

Mesmo antes de viajar pela segunda vez, em 2011, (07/09/11 a 19/09/11), já havia pensado na alternância nós e a gente em contextos de primeira pessoa do plural como fenômeno linguístico para a análise, visto que, até então, nenhum estudioso havia 
registrado essa variação nas pesquisas sobre o português uruguaio. E, na segunda pesquisa de campo, agora com os uruguaios, percebi que de fato eles também utilizavam de forma variável nós e a gente.

A escolha dessa variável linguística é de suma importância para os estudos de contato linguístico na fronteira Brasil-Uruguai, porque nos ajuda a entender como funciona o português uruguaio e qual a sua relação com o português brasileiro da fronteira e de outras localidades.

A expressão português uruguaio de Aceguá refere-se ao português falado como língua materna pelos bilíngues uruguaios dessa fronteira. Já a expressão português brasileiro de Aceguá refere-se ao português falado como língua materna pelos monolíngues brasileiros dessa fronteira. Quando se fala em português uruguaio só pode ser da fronteira, uma vez que não existe português em outras regiões do Uruguai fora da zona fronteiriça.

Como o objetivo do trabalho é analisar um fenômeno variável no âmbito do contato de línguas, seguimos os parâmetros de pesquisa da Sociolinguística Variacionista, por meio da teoria da Variação, de Labov (2008 [1972] e 2001), e da Mudança Linguística, de Weinreich, Labov, Herzog (2006).

Esse trabalho busca, portanto, evidências para uma mudança linguística recente no português uruguaio de Aceguá por meio dos seguintes percursos: (i) inexistência documental da variação pronominal de primeira pessoa do plural na fronteira; (ii) caminho da mudança linguística via função sintática; (iii) inexistência da expressão $a$ gente vamos, o que mostra menos encaixamento linguístico na fronteira; (iv) categoricidade do pronome nós em 9 entrevistas com uruguaios contra apenas 3 entrevistas com brasileiros, de um total de 19 entrevistas com brasileiros e 19 entrevistas com uruguaios.

Para o suporte quantitativo, contamos com o auxílio do programa Goldvarb-X de Sankoff, Tagliamonte \& Smith (2005), que é considerado uma ferramenta de análise sociolinguística. Segundo Labov (2008), um estudo sociolinguístico tem de se basear em pesquisas empíricas e quantitativas a fim de compreender melhor o encaixamento social e linguístico de cada fenômeno variável.

A abordagem variacionista é necessária, porque não é possível fazer um estudo sobre variação linguística sem entender os padrões linguísticos e sociais que delineiam determinado fenômeno linguístico. E, para realizar essa pesquisa de forma confiável, recorre-se à estatística, mas apenas como uma das ferramentas para chegar aos 
resultados, mesmo porque utilizaremos também métodos qualitativos para o estudo por meio de fotos, observação participante, investigação documental, pesquisa de campo com entrevistas e de análise da identidade linguística da fronteira.

A respeito do contato linguístico, do português da fronteira e dos estudos fronteiriços, temos como referência, principalmente, Weinreich (1953), Rona (1963), Hensey (1972), Elizaincín, Behares e Barrios (1987), Elizaincín (1992), Carvalho (2003, 2008) e Behares (2010).

A base teórica para os estudos de contato, sobretudo em contextos bilíngues, é a de Poplack (1993), que analisa o contato linguístico através da variação. Sobre a situação de contato linguístico na fronteira, a convergência linguística, o bilinguismo, a primazia dos fatores sociais ou dos fatores linguísticos e as consequências linguísticas como o code-switching, mencionamos também os autores Silva-Corvalán (1994), Garret (2006), Thomason (2008), Carvalho (2012) e Muysken (2013).

Se na língua espanhola há o correspondente "nosotros" para a primeira pessoa do plural, o esperado era que houvesse convergência (POPLACK, 1993, p. 256) para o pronome semelhante nós do português brasileiro. Mesmo tendo uma variante correspondente, identificamos que os bilíngues uruguaios, nas entrevistas feitas em 2011, já utilizavam o pronome a gente no mesmo contexto linguístico do português brasileiro, ou seja, como primeira pessoa do plural e com o mesmo valor de verdade de nós, totalmente oposto ao uso do la(s) gente(s) impessoal do espanhol.

Para as questões de identidade, território, Ecolinguística, nacionalidade, alteridade, pós-modernidade, identidade discursiva e significado social das variantes, trabalhamos com os autores Lash (1997), Woodward (1997), Lévy (1999), Moita Lopes \& Bastos (2002), Baumam (2001), Guiddens (2002), Dealtry (2002), Haesbaert (2002), Trindade (2002), Olinto (2002), Coracini (2003), Uyeno (2003), Leray (2003), Scherer, Morales e Leclerq (2003), Pagotto (2004), Hall (2005), Ivo (2013) e Couto (2007, 2009). No caso da identidade, o pronome a gente entra na comunidade uruguaia como sujeito discursivo e não fere a identidade múltipla e líquida.

Posto isso, a tese deste trabalho é a entrada do pronome a gente na comunidade bilíngue uruguaia como um elemento ratificador da variedade do português uruguaio da fronteira e como elemento que aproxima o português uruguaio ao português brasileiro da fronteira e do restante do Brasil. Assim, contribui-se para a discussão sobre a definição do português uruguaio, como propõe Carvalho (2003), com a inserção do pronome de primeira pessoa do plural a gente, tipicamente brasileiro e urbano. Essa 
aproximação do português uruguaio ao português brasileiro urbano já havia sido descrita por Carvalho (2008) por meio da palatalização de /t/, /d/ (2004) e /lh/ (2003).

Portanto, não se trata de portunhol ou qualquer outra denominação que reflete a ideologia da mistura de línguas, mas sim de um português uruguaio que mostra tendências urbanizadoras parecidas com o português brasileiro. Mesmo diante dessa outra realidade linguística, o português é sempre descrito como língua do Brasil, de Portugal, da Ásia, da África e da Oceania. E por que não português do norte do Uruguai?

Assim, a hipótese geral, de cunho quantitativo, é de que o pronome a gente no português uruguaio de Aceguá é menos frequente e não ocorre em todos os contextos linguísticos do português brasileiro de Aceguá, já que este se encontra em fase mais avançada na mudança linguística e na gramaticalização do pronome a gente como na maior parte do português brasileiro como um todo. Esse panorama seria consequência da inovação na inserção de a gente como pronome de primeira pessoa do plural também no português uruguaio.

Com essa discussão e para um entendimento mais global do fenômeno, apresentamos algumas questões de pesquisa, de cunho qualitativo, sobre o estudo da variação entre nós e a gente na fronteira Brasil-Uruguai:

(i) O pronome a gente, amplamente utilizado no Brasil e na zona urbana, chega ao sul do país, mas atravessa a fronteira?

(ii) $\mathrm{O}$ pronome a gente está entrando no português uruguaio de Aceguá em que função sintática?

(iii) A distribuição de nós e a gente nos dados do português uruguaio e do português brasileiro, ambos de Aceguá, se assemelha à distribuição de nós e a gente nas diversas regiões brasileiras, sobretudo na região Sul, onde se localiza Aceguá?

(iv) O grau de bilinguismo dos uruguaios interfere no uso de a gente?

(v) Que variáveis sociais e linguísticas condicionam a presença de a gente nas variedades de português faladas em Aceguá?

(vi) A inserção do pronome $a$ gente no português uruguaio é consequência do contato linguístico com o português ou é da própria natureza histórica e evolutiva do português uruguaio? 
(vii) Como a identidade sociolinguística é formada e constituída na fronteira e de que forma ela interfere no falar local?

Para obtenção dos resultados, foram feitas seis análises variacionistas (i) com os dados de todos os colaboradores dos dois lados da fronteira, levando em consideração a comunidade como um todo (ii) sem os dados dos colaboradores brasileiros e uruguaios de uso categórico de nós; (iii) com os dados de todos os brasileiros do lado de AceguáBrasil (iv) sem os dados dos brasileiros de uso categórico de nós; (v) com os dados de todos os uruguaios do lado de Aceguá-Uruguai e (vi) sem os dados dos uruguaios de uso categórico de nós. Posto isso, será possível comparar as diferentes análises e ver até que ponto se assemelham ou se diferenciam, além de identificar a região do Brasil da qual a realidade fronteiriça mais se aproxima, por meio dos inúmeros trabalhos sobre o português brasileiro.

A inovação desse trabalho está no estudo do pronome de primeira pessoa do plural a gente em variação com nós no português uruguaio; na comparação entre o português de ambos os lados da fronteira; na relação identitária atribuída ao significado social dessas variantes e na própria investigação linguística na fronteira de Aceguá, até então não estudada. Assim, a estrutura da tese é composta por seis capítulos:

O capítulo 1 aborda o contexto histórico-geográfico passado e atual da fronteira Brasil-Uruguai e da comunidade de Aceguá, a ocupação e povoação da fronteira e o desenvolvimento fronteiriço para que possamos compreender melhor o contexto geral da interação linguística na região. A forte presença dos portugueses no norte do Uruguai desde o século XVI pode auxiliar no entendimento das questões linguísticas da fronteira, sobretudo da presença de um pronome (a gente) tipicamente brasileiro também no português uruguaio.

O capítulo 2 descreve o contato linguístico entre o espanhol e o português na fronteira sul, os empréstimos lexicais e o code-switching, assim como os precursores dos estudos fronteiriços e as nomenclaturas relacionadas ao falar fronteiriço na comunidade bilíngue de Aceguá, tais como dialeto misto, fronterizo, (pré-)pidgin, interlecto, portunhol, DPU (Dialetos Portugueses do Uruguai) e PU (Português Uruguaio). 
O capítulo 3 relata aspectos diacrônicos e sincrônicos dos pronomes de primeira pessoa do plural, desde o latim e o português arcaico até chegar ao português brasileiro e ao português europeu, passando pelo registro da gramática tradicional e pela explicação das gramáticas descritivas acerca dos usos reais da língua.

O capítulo 4 refere-se aos princípios teóricos e metodológicos da Sociolinguística Variacionista, bem como à pesquisa de campo, à constituição da amostra, das hipóteses e das variáveis linguísticas e sociais da alternância nós e a gente como primeira pessoa do plural.

O capítulo 5 se destina à análise variacionista de nós e a gente e às variáveis selecionadas pelo programa estatístico em seis etapas de análise: (i) brasileiros e uruguaios com todos os colaboradores e (ii) sem os categóricos em nós; (iii) apenas brasileiros com todos os colaboradores e (iv) sem os categóricos em nós; (v) apenas uruguaios com todos os colaboradores e (vi) sem os categóricos em nós. Esse capítulo também contempla a variação na concordância de número dos sintagmas verbais de primeira pessoa do plural a fim de entender melhor o encaixamento linguístico desse fenômeno, ainda que seja sem o tratamento estatístico de dados. Exemplificamos os tipos de concordância encontrados nos dados de Aceguá e apresentamos algumas explicações sobre como esse fenômeno linguístico ocorre na fronteira, no espanhol e no português brasileiro e uruguaio.

O capítulo 6 traz uma análise qualitativa da identidade sociolinguística fronteiriça e do significado social atribuído às variantes nós e a gente. A identidade é analisada em paralelo com o territórico, a Ecolinguística, a nacionalidade, a percepção das diferenças, a pós-modernidade e os significados discursivos e sociais das variantes. Além disso, ressalta-se a forma como o morador da fronteira se vê e como os outros o veem (se uruguaio ou brasileiro, se bilíngue ou não). A partir disso, discutimos um pouco sobre prestígio das línguas e normas linguísticas compartilhadas nos contextos de fala citados pelos entrevistados.

As considerações finais retomam as questões explicitadas na introdução para respondê-las a partir dos resultados encontrados e das análises feitas. Trazem, portanto, os resultados linguísticos e sociais que condicionam o uso dos pronomes de primeira 
pessoa do plural e a ausência ou presença de concordância de número; as discussões acerca da urbanização do português uruguaio e da inovação linguística de a gente no português uruguaio; a relação da variação linguística de primeira pessoa do plural com as questões identitárias da fronteira; a real necessidade de distinguir a variedade linguística de português falado no Uruguai como língua materna de outras denominações indevidas para esse contexto sociolinguístico, como portunhol, mistura de línguas etc; e as perspectivas futuras de análises e estudos ainda não contemplados nesse trabalho.

Como apêndice/anexo, respectivamente, estão o modelo de TCLE (Termo de Consentimento Livre e Esclarecido), que foi assinado pelos entrevistados, e a aprovação do comitê de ética. 


\title{
CAPÍTULO 1 - ANTECEDENTES HISTÓRICOS E GEOGRÁFICOS DA FRONTEIRA BRASIL-URUGUAI
}

\begin{abstract}
Só não sabe para onde vai quem não conhece de onde vem. Essa é uma frase que eu mesmo criei, e se tu não sabe da onde tu veio, eu sou do Rio Grande do Sul, tu não vai saber nunca quem tu é. Essa é a essência. [...] Mas é isso, a fronteira é isso. [...] O significado da palavra fronteira, um momento antes $e$ um momento depois. Esse é o significado da palavra fronteira. Isso eu aprendi com um ex-chefe meu, despachante aduaneiro há 30 anos, e é bem o que é, um momento antes e um momento depois. A gente tá vivendo tudo e nada. A gente vive o hoje e o passado, o amanhã e o passado.
\end{abstract}

(EDI, morador de Aceguá)

O objetivo desse capítulo é fazer um histórico sobre a fronteira Brasil-Uruguai e da disputa fronteiriça entre Portugal e Espanha para melhor compreendermos o contexto atual de Aceguá. Para isso, foi feita uma pesquisa documental e bibliográfica acerca da história e geografia local, além da condição atual de desenvolvimento fronteiriço, por meio de textos de alguns estudiosos e teóricos sobre o assunto.

Na primeira ida a Aceguá, em outubro de 2009, encontrei documentos históricos na escola brasileira e uruguaia, na prefeitura, e no museu D. Diogo de Souza, em Bagé, bastante incompletos, sem data ou sem a referência bibliográfica. De qualquer forma, esses documentos e outros textos serviram de base para a construção desse capítulo a partir de algumas informações sobre a comunidade de Aceguá em consonância com fatores históricos binacionais que ocorreram nesse mesmo período.

Como referências documentais, foram consultados El País, Uruguay y sus 19 departamentos (s/a e s/d ${ }^{1}$, p. 11-12); texto do engenheiro agrônomo Julio Cezar Vinholes Pinto (s/d); Juan Carlos Pedemonte (1985), Assembléia Geral, sessão de 18 de abril de 1863; Nicolas Lengua, Lei de 9 de julho de 1862, Art. 1; Ricardo Garcia (s/d); Faccio (s/d); Eduardo Acosta (s/d); Tadêo (s/d); Lucas e Zuge (2010); Relato de una vida empresarial (s/d, p.1); SIAB (Sistema de Informação de Atenção Básica de 2009) e Aceguá (2010).

Como referências históricas, foram consultados os livros de Abreu (1998); Arteaga (2008); Bandeira (1998); Calógeras (1972); Golin (2004); Holanda (2003); Lima (2000). Sobre a perspectiva da nova agenda para a cooperação e o desenvolvimento fronteiriço, temos Aveiro (2006). Como referências geográficas,

\footnotetext{
${ }^{1}$ As siglas s/a e s/d significam, respectivamente, sem autor e sem data.
} 
consultamos o estudo de Castrogiovanni (2010), do departamento de Geografia da UFRGS, e Costa (2010), do departamento da Antropologia da UFMS. Esses trabalhos de 2010 fazem parte de uma coletânea intitulada "Estudos fronteiriços", organizada pela UFMS.

\subsection{0 que é fronteira?}

O conceito tradicional de fronteira como sendo o limite extremo ou final do território tornou-se ultrapassado perante a integração vivenciada na fronteira do BrasilUruguai. No caso de Aceguá, trata-se de uma cidade geminada, onde existe apenas uma rua delimitando a divisa entre os dois países. Como não há nenhum acidente geográfico (relevo, montanha, vale, serra, lago, rio), a localidade é conhecida como fronteira seca.

Em tese, a própria nomenclatura de fronteira e/ou limite é usada indistintamente, mesmo em contextos acadêmicos. Por isso, é necessário fazer a distinção entre os dois. O limite é abstrato, artificial e diplomaticamente separa dois territórios. A materialização do limite é a demarcação, ou seja, a construção de marcos e balizas para dividir ou separar as regiões. Essa linha demarcatória ou delimitada não é habitada. A fronteira já é uma zona que constitui uma faixa de território, a faixa da fronteira, ou seja, é meramente matemática, de extensão e largura definidas. A largura da fronteira no Sul do Brasil, prevista pela Lei 6.63479, referendada na Constituição Federal de 1988, é de $150 \mathrm{~km}$ atuais. Assim, o limite indica forças centrípetas, mas a fronteira pode estar dominada por forças centrífugas geradoras de contatos múltiplos com as populações vizinhas do além-limite (CASTROGIOVANNI, 2010, p. 28-29).

Posto isso, é importante entender que a fronteira é um espaço em movimento, vivo e vivido. As regiões de fronteira (a partir da vida de seus moradores) representam, muitas vezes, o papel de protagonistas na formação dos Estados-Nacionais, ainda que as narrativas oficiais as considerem como áreas marginais e coadjuvantes neste processo (COSTA, 2010, p. 95).

A região da fronteira Brasil-Uruguai foi muito disputada historicamente, e sempre houve a tentativa política de separação rígida entre os povos, culturas e nações, ainda que a prática cotidiana fosse pacífica e comum em ambas as populações. Como se trata de uma fronteira viva, habitável, a identidade local sempre foi mais forte do que os conflitos ao longo dos 1000 quilômetros de linha divisória demarcada na fronteira (AVEIRO, 2006). 
Na fronteira, as relações são mais cooperativas entre os dois povos, já que há integração sociocultural e espacial entre eles, ou seja, esses habitantes respeitam as diferenças ao mesmo tempo em que compartilham de uma identidade fronteiriça comum, pois compartilham as mesmas experiências culturais. Os espaços também são quase sempre integrados, seja na vizinhança, na escola, no comércio, nos laços de parentesco, nas comemorações festivas, etc.

De ambos os lados da fronteira Brasil-Uruguai, formou-se uma zona fronteiriça com mais de 720 mil habitantes, cerca de $52 \%$ do território do estado do Rio Grande do Sul e $16 \%$ do território do Uruguai. Na faixa limítrofe, encontram-se as seis cidades fronteiriças: Chuí-Chuy, Jaguarão-Río Branco, Aceguá-Acegua, Sant’Ana do Livramento, Quaraí-Artigas, Barra do Quaraí-Bella Unión. Conscientes das demandas surgidas por essas fronteiras vivas, Brasil e Uruguai, na década de 90, criaram os Comitês de fronteira nessas conurbações (crescimento urbano ou urbanização). ${ }^{2}$

O Uruguai, na época Província Cisplatina, foi parte do território brasileiro até a sua independência entre 1810 e 1828. Assim, o contato intenso e comum entre brasileiros e uruguaios sempre existiu em diversos aspectos da vida social, econômica e cultural. Os costumes típicos dessa região fronteiriça diferem-se de outros lugares do Brasil e do Uruguai, caracterizando a vida de uma população integrada e distinta das demais localidades (AVEIRO, 2006).

Em face também da globalização, além dos fatores históricos, sociais e geográficos já citados, percebe-se que há um sentimento de pertencimento à comunidade fronteiriça, de forma centralizadora. Como Aceguá é pequena, as pessoas mantêm um fluxo intenso de idas e vindas rumo aos dois países, tornando o contato totalmente integrado.

No entanto, no processo histórico da fronteira, Brasil e Uruguai buscaram desestimular a integração e o desenvolvimento fronteiriços, dificultando a formação das cidades nas fronteiras e o convívio entre brasileiros ao sul e uruguaios ao norte, desde o Tratado de Limites em 1851. Mesmo assim, o sentimento de pertencimento à fronteira esteve presente entre uruguaios e gaúchos que vivem atualmente em harmonia e paz, diferentemente de outras épocas. Segundo Castrogiovanni (2010, p.12), a importância do estudo da fronteira sul deve-se necessariamente ao que ela foi, é e será:

\footnotetext{
2 Informação disponível no site da Embaixada do Brasil em Montevideu. Disponível em: http://www.brasil.org.uy/br/home/home/index.php?menu=sub1_7\&t=secciones\&secc=421. Acesso em: 2 mar. 2012.
} 
É bom lembrarmos que o espaço geográfico é um acúmulo desigual de tempos e a fronteira sem dúvida não está alheia a essa lógica. O que ela foi ainda interfere em nossa sociedade e esta percepção nos ajuda a moldar o que ela ainda é ou poderá vir a ser.

Dessa forma, torna-se imprescindível uma breve retrospectiva da fronteira Brasil-Uruguai e, consequentemente, de Aceguá, para melhor entendermos o contexto histórico por que passou essa região ao longo dos anos. Assim, certamente, entenderemos melhor a comunidade atual, inclusive as questões linguísticas inerentes ao contato de línguas e o porquê de o português prevalecer nessa região fronteiriça.

\subsection{A história da fronteira luso-espanhola na América}

A disputa luso-espanhola na fronteira americana teve inúmeros interesses econômicos, políticos e marítimos. Enquanto os espanhóis encontravam minas de ouro e prata no Império Inca, apesar de ter a Cordilheira dos Andes como uma muralha natural difícil de transpor, os portugueses somente encontravam pau-brasil. Isso motivava os luso-brasileiros a desobedecer a linha de demarcação do Tratado de Tordesilhas (AVEIRO, 2006).

Em 1493, surge a Bula "Inter Coetera", do Papa Alexandre VI, que estipulava que as terras descobertas a 100 léguas a oeste das Ilhas de Cabo Verde e Açores pertenceriam ao reino da Espanha, o que prejudicava Portugal. Já em 1494, os Reinos de Portugal e Espanha firmam o Tratado de Tordesilhas que estabelecia a divisão entre as duas coroas a partir da ilha de Cabo Verde. Esse tratado modificou o número de léguas e anulou a Bula "Inter Coetera" (ABREU, 1998, p. 169). Ainda assim, não foi o suficiente para impedir os portugueses de continuar avançando o território delimitado.

O Uruguai entra na história em 1516 com a descoberta do Rio da Prata. Mas o Estado surge no século XIX, porque antes foi um espaço mais amplo, denominado Banda Oriental do rio Uruguai, com limite oriental do oceano Atlântico e da linha de Tordesilhas, fixada por Espanha e Portugal em 1494, só dois anos depois do descobrimento da América. Essa localidade foi muito cobiçada devido à riqueza pecuária (ARTEAGA, 2008, p. 11 e 14). Além disso, o interesse estava em torno das posses no Oriente, da fundação de Buenos Aires e da expansão comercial na bacia do Prata. 
O primeiro relato histórico do município de Aceguá remonta ao ano de 1660, no fim do século XVII, quando os Espanhóis, vindos da Banda Oriental, entraram em Aceguá e fundaram a redução de Santo André do Guenoas, em 1683 (TADÊO, s/d, p.3 e ACEGUÁ, 2010).

Segundo Tadêo (s/d, p. x-xi), em 1703, a maior parte do território de Aceguá era território de ninguém. Por isso, essa região ficou conhecida como campo neutral e foi disputada por indígenas e, posteriormente, pelo colonizador por razões diversas, tais como:

- Ampla visão da campanha, que circundava a serra;

- Elevado número de vertentes em todo o largo da serra;

- Excelente qualidade da água, inclusive, há alguns anos, quatro lagoas nunca secavam, o que servia de suporte aos mananciais da serra;

- Boa qualidade das pastagens nessa parte da serra;

- Facilidade de acesso e transposição (situação topográfica) no território de ninguém, ou seja, nos campos neutrais;

- Situação geográfica central e estratégica, caminho natural que ligava as missões ao Rio da Prata com poucos acidentes geográficos de vulto.

Ricardo Garcia (s/d) afirma que nas terras de Aceguá aconteceram as primeiras resistências contra as demarcações. Tal movimento teve início em 1752 (século XVIII). Por isso, em Aceguá, também foram fixados redutos dos índios que eram contra a catequização dos padres jesuítas da Companhia de Jesus. Segundo Tadêo (s/d, p. VI), os índios dessa terra têm sua característica de resistência e rebeldia registrada já nos primeiros documentos da história escrita, porque foram os que mais resistiram às invasões portuguesas e espanholas.

De acordo com Arteaga (2008, p.13), a influência guarani foi muito grande no Uruguai, uma vez que foram evangelizados pelos sacerdotes da Companhia de Jesus e fizeram parte das reduções uruguaias. Os sete povos das Missões Orientais, que tiveram seu período de auge na primeira metade do século XVII (1600 a 1609), também formaram parte da Banda Oriental. Esses povos tinham sua própria administração.

A Companhia de Jesus foi fruto da grande expansão europeia do século XVI. Chegando primeiro no Brasil, onde fundaram São Paulo, os jesuítas começaram seu 
trabalho missioneiro no Rio da Prata desde o Paraguai, estabelecendo reduções com índios guaranis desde 1610. São Paulo deu origem às "bandeiras", expedições que tinham como objetivo caçar índios para vendê-los como mão de obra barata nas plantações do nordeste brasileiro. No Uruguai, de 1636 a 1638, as bandeiras também atacaram as reduções uruguaias com o fim de escravizar os índios (ARTEAGA, 2008, p. 16).

As Missões Orientais cumpriram um papel de banda-fronteira, uma marca hispânica, terra disputada pelos impérios. Fazem parte dos Sete Povos das Missões: São Borja, São Nicolau, São Miguel, São Luís Gonzaga, São Lourenço, São João Batista, Santo Ângelo (ARTEAGA, 2008, p. 17). Os sete povos das Missões eram fazendas criadas pelos jesuítas que tinham como objetivo a conversão dos índios. Por isso, os jesuítas proibiam o uso do espanhol nas reduções. A estância de São Miguel era a mais próxima de Aceguá.

Os indígenas, especialmente os guaranis, por meio da companhia de Jesus, contribuíram para a introdução e dispersão do gado na Banda Oriental, a formação das estâncias dos povos no norte do rio Negro e da "Vaquería del Mar" sobre o Atlântico e a divulgação regional do consumo da erva mate.

Vaquería era um espécie de caça do gado, atividade destrutiva e depredatória. As vaquerías não exigiam propriedade da terra nem do gado. Esse descontrole conduziu à escassez e logo apareceu a estância com o aumento do valor da terra e do gado. A estância é uma unidade de produção baseada na procriação sob o conceito de propriedade privada (ARTEAGA, 2008, p. 34)

O passado missioneiro, de 1626 a 1640, acentuou o intercâmbio no noroeste do Uruguai a partir das Missões Jesuíticas. O gado introduzido em 1634 pelos jesuítas nas missões orientais do Uruguai, para o sustento desses povos, foi a origem da "Vaquería del Mar". A livre reprodução do gado converteu a terra baldia e ignorada na "bandavaquería" em uma verdadeira mina de carne e couro, que provocou um interesse econômico do europeu (ARTEAGA, 2008, p. 16-18).

A fundação pelos portugueses da Colônia do Sacramento em 1680, em uma pequena enseada do Rio da Prata, colocou o tema em voga e obrigou a Espanha a encarar seriamente o povoamento da Banda Oriental. Essa fundação foi parte de uma política expansionista comercial da Coroa lusitana, que considerava o Rio da Prata um importante acesso de navegação (ARTEAGA, 2008, p.16-18). Assim, Portugal 
objetivava avançar à linha fixada pelo Tratado de Tordesilhas (Elizaincín, Behares e Barrios, 1987, p. 35). Em 1703, a Colônia do Sacramento volta a ser da Espanha.

A Colônia do Sacramento foi de Portugal e Espanha por diversas vezes e, portanto, bastante disputada pelo fluxo na fronteira, contrabando ${ }^{3}$ e aumento do gado. A Inglaterra, em luta contra a Espanha e a França, também se interessava por essa Colônia. Segundo Bandeira (1998, p. 37), os ingleses obtiveram mais lucros que os portugueses com a Colônia do Sacramento. Por isso, para o autor, as vitórias diplomáticas de Portugal deveram-se muito mais à ascensão do poder econômico da Inglaterra capitalista e à decadência da Espanha do que propriamente à habilidade de seus embaixadores, como muitos historiadores acreditam.

Havia também o interesse português, além da Banda Oriental e do Rio de Prata, em avançar até Buenos Aires, que, por sinal, tinha forte presença de comerciantes e fazendeiros portugueses que aderiam à causa de Lisboa, também pela necessidade econômica suprida por Portugal, com a abertura dos negócios, a garantia de propriedade, o fornecimento de escravos, de açúcar do Brasil, de tecidos da Inglaterra e de outras mercadorias (BANDEIRA, 1998, p. 33 e 46). É importante ressaltar que os escravos são citados por esse autor como mais uma "coisa" fornecida pelos portugueses a Buenos Aires, provavelmente porque era a forma com que eles eram retratados naquela época.

Em 1724, os espanhóis fundam Montevidéu, mas possivelmente o norte do Uruguai permanecia com uma população rural lusofalante. Essa importante informação reforça a questão da presença histórica do português no Uruguai e, portanto, do bilinguismo até hoje na fronteira. $\mathrm{O}$ povoamento da região, que medeia a margem setentrional do Rio da Prata, Uruguai e Oceano Atlântico, só começou efetivamente a partir de 1736, cinquenta e seis anos depois da fundação da Colônia do Sacramento. Essa ocupação ocorreu devido à necessidade de garantir o espaço físico e o direito de navegação para o livre comércio.

\footnotetext{
${ }^{3} \mathrm{O}$ termo contrabando refere-se às relações comerciais de caráter internacional sem os trâmites legais. Pode ser considerado legal até a fronteira, e, a partir daí, se tornar contrabando. A origem do termo contrabando é histórica. Na época da colonização espanhola e portuguesa na América do Sul, os representantes das coroas detinham as ações civis e militares desenvolvidas nas Colônias. Publicavam bandos, que significavam ordens ou decretos-lei, para determinarem o que a população deveria cumprir. Em determinado bando, o vice-rei espanhol de Buenos Aires determina que a produção de couro (courama) de toda a Colônia seja toda enviada a Buenos Aires. Todo e qualquer carregamento de couro que não se dirigisse a Capital seria considerado "contra-bando", portanto, um crime contra a Coroa e a Nação (TADÊO, s/d, p. xix). Para Elizaincín, Behares e Barrios (1987, p. 36), o contrabando só começa a preocupar a Espanha depois da fundação de Montevidéu.
} 
A partir dos núcleos populacionais, formados entre as campanhas circunvizinhas da Colônia do Sacramento e a barra do Rio Grande, os aventureiros, que surgiram e se notabilizaram como gaúchos ou gaudérios, empreendiam a tarefa de arrebanhar manadas de bois, mulas e cavalos, em paragens pertencentes à Espanha, a fim de remeter ao interior do Brasil (BANDEIRA, 2008, p. 38-39).

O Tratado de Madri ou Permuta, em 1750, teve como objetivo buscar a paz na região da fronteira. Na prática, Portugal cedia à Espanha a Colônia de Sacramento e renunciava suas pretensões sobre o Rio da Prata. Em troca, para ficar com a navegação exclusiva do Prata (ABREU, 1998, p. 174 e 176), a Espanha entregava os sete povos das Missões orientais e a Lagoa Mirim na Banda Oriental e esquecia suas pretensões territoriais baseadas no meridiano de Tordesilhas. Cedia, então, a Portugal os atuais territórios do Rio Grande do Sul, Santa Catarina e Paraná (ARTEAGA, 2008, p.26).

Ainda segundo Arteaga (2008, p. 27), o Tratado de Madrid significou o abandono dos direitos espanhóis que dava o meridiano de Tordesilhas. Por isso, os sete povos tiveram de sair do local para ser entregue a Portugal. Os índios lutaram contra, mas foram vencidos pelo exército português. Esse tratado foi a primeira tentativa de fixar limite entre os dois impérios, mas os conflitos não cessaram.

Esse acordo deixou como herança uma "fronteira de contato", já que havia legalizado os avanços portugueses sobre o Rio Grande do Sul (ARTEAGA, 2008, p. 34), os quais foram responsáveis pela grande conquista territorial portuguesa com relação ao Brasil. Nesse sentido, os jesuítas foram importantes na vitória portuguesa, porque conheciam bastante a região.

O Tratado de Madri foi importante, porque até então, com o tratado de Tordesilhas, ambas as nações infringiram os limites impostos. Agora, a linha meridiana era substituída por uma linha natural, a partir das passagens já conhecidas (ABREU, 1998, p. 174). Ainda assim, em 1752, há o registro de que um grupo de índios barrou em Aceguá os trabalhos da Comissão de demarcação dos limites portugueses e espanhóis para cumprimento do Tratado de Madri (TADÊO, s/d, p xi).

Em dezembro de 1753, os dois exércitos, português e espanhol, saindo respectivamente de Rio Grande e da Colônia de Sacramento, iniciaram a marcha em direção a Santa Tecla, localidade do povo de São Miguel, situada ao norte de Bagé, da qual fazia parte Aceguá (ABREU, 1998, p. 176). Zuge e Lucas (2010) afirmam que, segundo os diários de marcha, o exército Português chegou às cabeceiras do Rio Negro, 
hoje no Uruguai, onde já estava acampado o exército Espanhol. Em 1773, os dois exércitos nomeados por Aceguá também partem para fundar o forte Santa Tecla (TADÊO, s/d, p. xi).

O departamento de Cerro Largo, onde se localiza a parte uruguaia de Aceguá, é um dos cinco que tem fronteira com o Brasil e foi uma demarcação de limites sempre disputada por portugueses e espanhóis. Entre 1751 e 1778, Cerro Largo foi virtualmente terra de ninguém, terra aberta, marginal e perigosa. Elizaincín (1992, p. 158) afirma que "No debe olvidarse que se trataba de vastas zonas prácticamente desiertas (en cierto sentido lo son aun hoy) con escasa o nula urbanización (la que llegará en el siglo XIX)”4. Era a rota do noroeste que abria caminho até o sul, depois da Lagoa Mirim. Essa localidade era considerada terra de outros, em realidade, e os outros eram os portugueses (El País, Uruguay y sus 19 departamentos, s/d, p. 11-12). Assim, nessa região da campanha, circulavam livremente paulistas, portugueses e castelhanos.

O artigo intitulado "Nasce la Guardia Nueva", da revista El país (s/d), explica que o noroeste do Uruguai já era um corredor geográfico antes da Vaquería del Mar, e teve o intercâmbio acentuado pelo passado missioneiro. Para proteger a orientalidade, começaram os processos de fundação em Cerro Largo com suas Guardas.

Segundo o mesmo artigo, o tratado de limites, firmado em Santo Idelfonso em 1777, semelhante ao Tratado de Madrid, avivou as demarcações, originou confusões de interpretação e facilitou a entrada de Portugal, porque aumentou a vulnerabilidade do limite noroeste da Banda Oriental. Os espanhóis definiram o limite de Portugal no novo continente, a linha de demarcação, enquanto os portugueses continuavam avançando muito mais ao oeste do que o proposto no Tratado de Tordesilhas quase três séculos antes (ABREU, 1998, p. 178).

O tratado de São Idelfonso foi o responsável por conceder a Colônia de Sacramento e as Missões Orientais à Espanha e o Rio Grande do Sul e Santa Catarina a Portugal. De acordo com Elizaincín, Behares e Barrios (1987, p. 37), com esse tratado, estabelece-se uma zona neutral (campos neutrais) na região fronteiriça.

Em 1801, Portugal tomou posse dos sete povos orientais por sua fragilidade e expulsão dos jesuítas. Em 1807, o Rio Grande do Sul foi elevado à categoria de Capitania de São Pedro. A criação das capitanias tinha como interesse, entre outros, fortalecer e proteger os territórios brasileiros contra supostas invasões espanholas.

\footnotetext{
${ }^{4}$ As citações em espanhol não foram traduzidas por causa da semelhança entre as duas línguas.
} 
Eduardo F. Acosta y Lara, citado em El país (s/d), afirma que a infiltração portuguesa no fim do século XVIII foi consequência lógica do colapso das Missões Jesuíticas, quando estas passam ao poder português.

Ainda de acordo com El país (s/d), Bagé (a $60 \mathrm{~km}$ de Aceguá) foi de posse espanhola, depois portuguesa, voltou a ser espanhola, até que veio a rendição final portuguesa. Como antigamente Aceguá era município de Bagé, pressupõe-se que a fronteira de Aceguá também teve a presença histórica de portugueses e espanhóis.

Em 1811, D. João reforça o Sul e a região do Prata com a incorporação da Banda Oriental ao território português, conhecida agora como Província Cisplatina. Segundo Bandeira (1998, p. 41), o sonho de D. João era fundar um poderoso império na América com os estados do Brasil e as colônias da Espanha, dominadas na época por Napoleão Bonaparte.

Segundo o Relato de una vida empresarial (s/d, p.1) ${ }^{5}$, no século XIX, as bandas fronteiriças entre o Uruguai e o Brasil se encontravam em plena efervescência com as revoluções e as guerras locais. O elemento espanhol, em sua maioria basco e galego, esteve presente na campanha oriental durante esses anos, sempre com a mente voltada a mover a economia, razão pela qual ali se encontravam.

Um dos maiores impasses para a paz na região foi a ambição dos dois países em dominar o Rio da Prata, local almejado por causa da expansão comercial e territorial. O motivo de tanta disputa e do avanço português constante na margem leste do Rio Uruguai, conhecida como Banda Oriental, era também a busca por riquezas materiais, a partir dos estímulos do mercado mundial. Por isso, com a extração do ouro, o processo de expansão territorial diminuiu. Além disso, havia a indústria e o comércio do couro e da carne de charque, rebanho bovino, estoques de mulas e cavalos e o desenvolvimento da pecuária e seus derivados (BANDEIRA, 1998, p. 38-41).

Os portugueses habilmente argumentavam que a região precisava de proteção e segurança, uma vez que a Espanha havia abandonado a região da fronteira na América (HOLANDA, 2003 p. 342). Um dos motivos para que a Espanha não se interessasse de imediato pela região fronteiriça era porque havia mais minérios do lado do Pacífico, desde a época do Império Inca (BANDEIRA, 1998, p. 21). E quando a Espanha se manifestou contra a conquista do Uruguai, os portugueses também se posicionaram

\footnotetext{
${ }^{5}$ Esse documento descreve o percurso vivenciado por uma empresa comercial na fronteira, que em 2006 completou um centenário de existência.
} 
dizendo que o governo espanhol, até então, nada tinha feito para manter a ordem nos territórios fronteiriços (HOLANDA, 2003, p. 364).

Assim, ao que tudo indica, parece que os espanhóis não imaginavam tamanha perspicácia dos portugueses, pois preocuparam-se mais com a posse de outros territórios, achando que a fronteira não seria tão disputada. Segundo Abreu (1998, p. 172),

os espanhóis não curaram de ocupar a margem esquerda do Prata, descuido verdadeiramente inexplicável, se não duvidavam de seus direitos, a menos que se não explique pela certeza de sua intangibilidade.

Contra os espanhóis, a hegemonia de Buenos Aires e sua pretensão de conservar monopólio sobre o comércio do Rio da Prata, surge José Artigas como figura principal dessa luta no Uruguai (BANDEIRA, 1998, p. 43). Artigas lutava pela liberdade da província e, por isso, era conhecido como "Chefe dos Orientais e Protetor dos Povos Livres" (HOLANDA, 2003, p. 353 e 358). No entanto, "ainda que bem delineados, os planos artiguistas não conseguiram deter os portugueses. Estes entraram em território uruguaio" (HOLANDA, 2003, p. 360-361). Na escola uruguaia de Aceguá, há escultura e homenagens a Artigas.

Em 1811, as tropas portuguesas, estacionadas em Cerro Largo, marchavam em direção a Montevidéu, passando por Aceguá, sob o comandado de D. Diogo de Sousa. Assim, D. Diogo entra facilmente em território uruguaio e avança até Maldonado. Sua intenção era continuar a ocupação até a Banda Oriental: fortaleza de Santa Tereza, Cerro Largo, margem do Uruguai (HOLANDA, 2003, p. 354-358).

Em 1815, o exército português invade o Uruguai ocupando-o durante 10 anos como parte do império brasileiro. É em 1821 que D. João VI oficializa a anexação da Banda Oriental ao Brasil com o nome de Província Cisplatina (BANDEIRA, 2008, p. 46-47). Para Calógeras (1972, p. 109), nada foi tão artificial quanto essa união forçada, já que

três séculos de guerra entre Espanha e Portugal protestavam contra o estabelecimento das tropas de D. João VI à margem esquerda do Rio da Prata, em 1817. Estava aniquilada a antiga metrópole, e as colônias hispânicas contra ela se tinham rebelado e haviam vencido. Buenos Aires, sem forças, nutriam em silêncio o ódio da impotência. Que poderia ela fazer para expelir o forasteiro invasor? Idêntico era o sentimento da Banda Oriental, tanto quanto ao dominador português, como quanto aos habitantes da margem direita do caudal. 
Com a Revolta da Cisplatina, em $1825^{6}$, em meio à independência do Brasil em 1822, o problema da união cisplatina volta à tona, provocando discórdia com outros países. Enquanto o Brasil reivindicava a Cisplatina por ter sido anexada a Portugal, a Argentina defendia que a Cisplatina era parte do antigo Vice-Reino da Prata. O problema também interessava à Grã-Bretanha, porque esse estado prolongado de guerra poderia prejudicar seus interesses comerciais e os investimentos dos ingleses, além de enfraquecer o regime monárquico no Brasil com as hostilidades no Rio de Prata (HOLANDA, 2003, p. 410).

Em 1828, a Província Cisplatina torna-se independente do Brasil e da Argentina e passa a se chamar República Oriental do Uruguai. Agora sim, o período maior de conflitos, desde 1680, se encerrava (HOLANDA, 2003, p. 374). Para Lima (2000, p. 189), a posse desse território era uma espécie de equilíbrio político do Rio da Prata porque

o Uruguai tornou-se assim um Estado-tampão - a expressão não era ainda do tempo, não havia sido ainda inventada, mas a ideia não podia deixar de ser antiga - e esse Estado-tampão, segundo a frase de um de seus mais ilustres filhos, Andrés Lamas, separava e garantia as fronteiras abertas, melhor do que o poderiam fazer os mais vigorosos limites naturais.

Ambas as nações admitiam sua independência, obrigando-se a garantir o novo Estado Livre. Pela primeira vez, em tratado internacional, havia a liberdade de navegação dos rios para as soberanias ribeirinhas (CALÓGERAS, 1972, p. 118).

Em 1851, foi assinado o Tratado de Limites que permitia livre acesso dos dois países no Rio Jaguarão e na Lagoa Mirim. Calógeras (1972, p. 229) afirma que a exclusiva utilização das águas da Lagoa Mirim e do Rio Jaguarão pelos portugueses, situação que durou até 1909 quando um novo acordo foi assinado, constrangia e humilhava os uruguaios. O Tratado de Limites foi importante para as delimitações de fronteira que iniciaram em Aceguá no ano de 1853, quando esta foi incorporada ao território do Brasil.

Apenas em 1914, em Aceguá, Uruguai e Brasil terminam de discutir os limites fronteiriços. De acordo com Pedemonte (1985), já existia um antigo marco levantado em 1852.

\footnotetext{
${ }^{6}$ Os 33 orientais, que vieram pela costa do Rio Negro, acamparam uma semana no Cerro de Aceguá (NICOLÁS LENGUAS, 1862).
} 
Esse marco foi delimitado a menos de vinte metros do antigo e foi o último marco fronteiriço entre Brasil e Uruguai, localizado em Aceguá. O atual marco ostenta placas e uma grande medalha de bronze, representando a cabeça do Barão de Rio Branco.

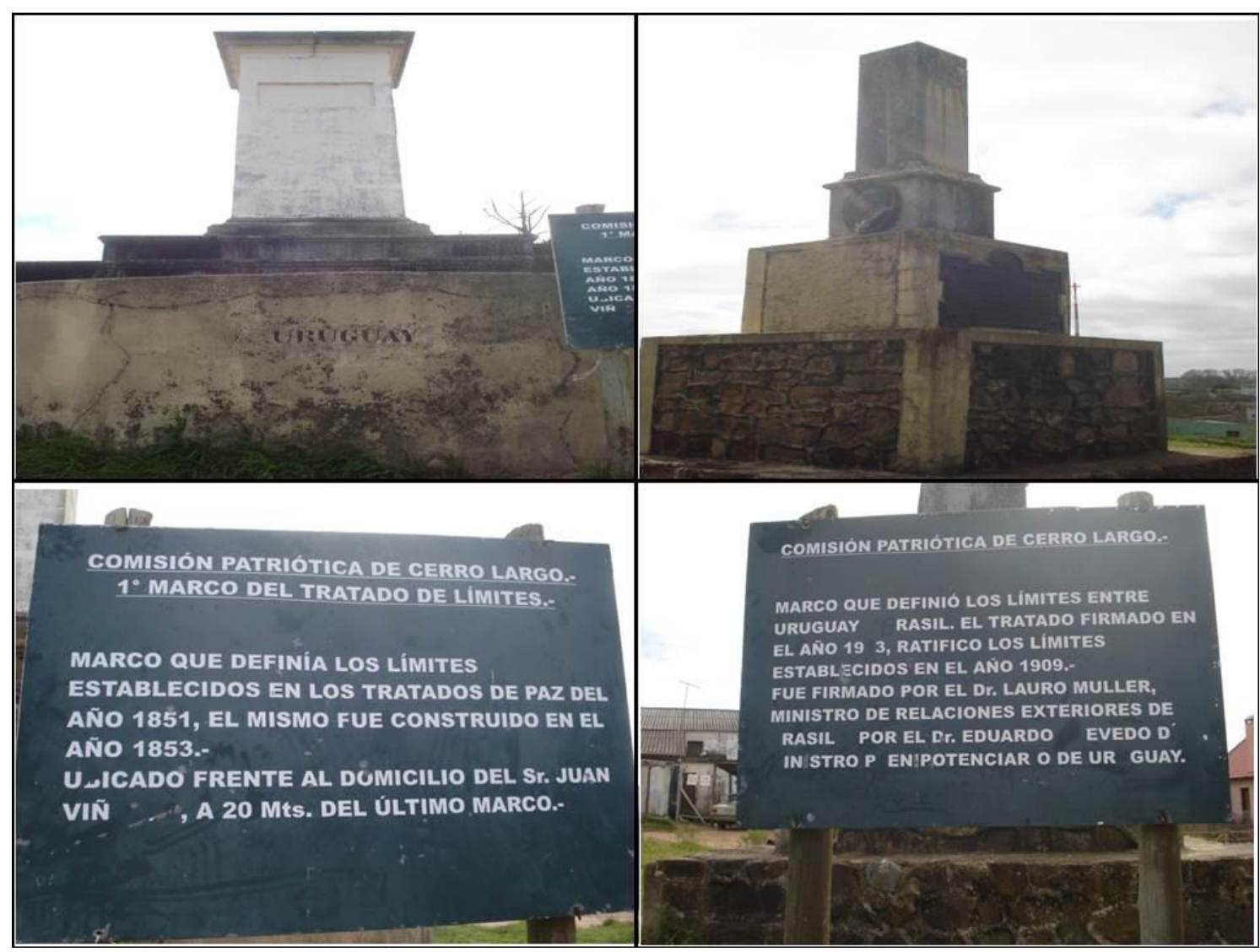

Foto 1: Placas sobre o Tatado de Limites.

A marcação política da fronteira demorou muito tempo por conta da distância, dos caminhos e conduções para os dirigentes de ambos os países chegarem ao local. Por isso, a demarcação da fronteira só iniciou-se pouco antes de 1911 (Relato de una vida empresarial, s/d.). Por fim, o último marco em Aceguá foi inaugurado em 1915 pela comissão patriótica de Cerro Largo. 


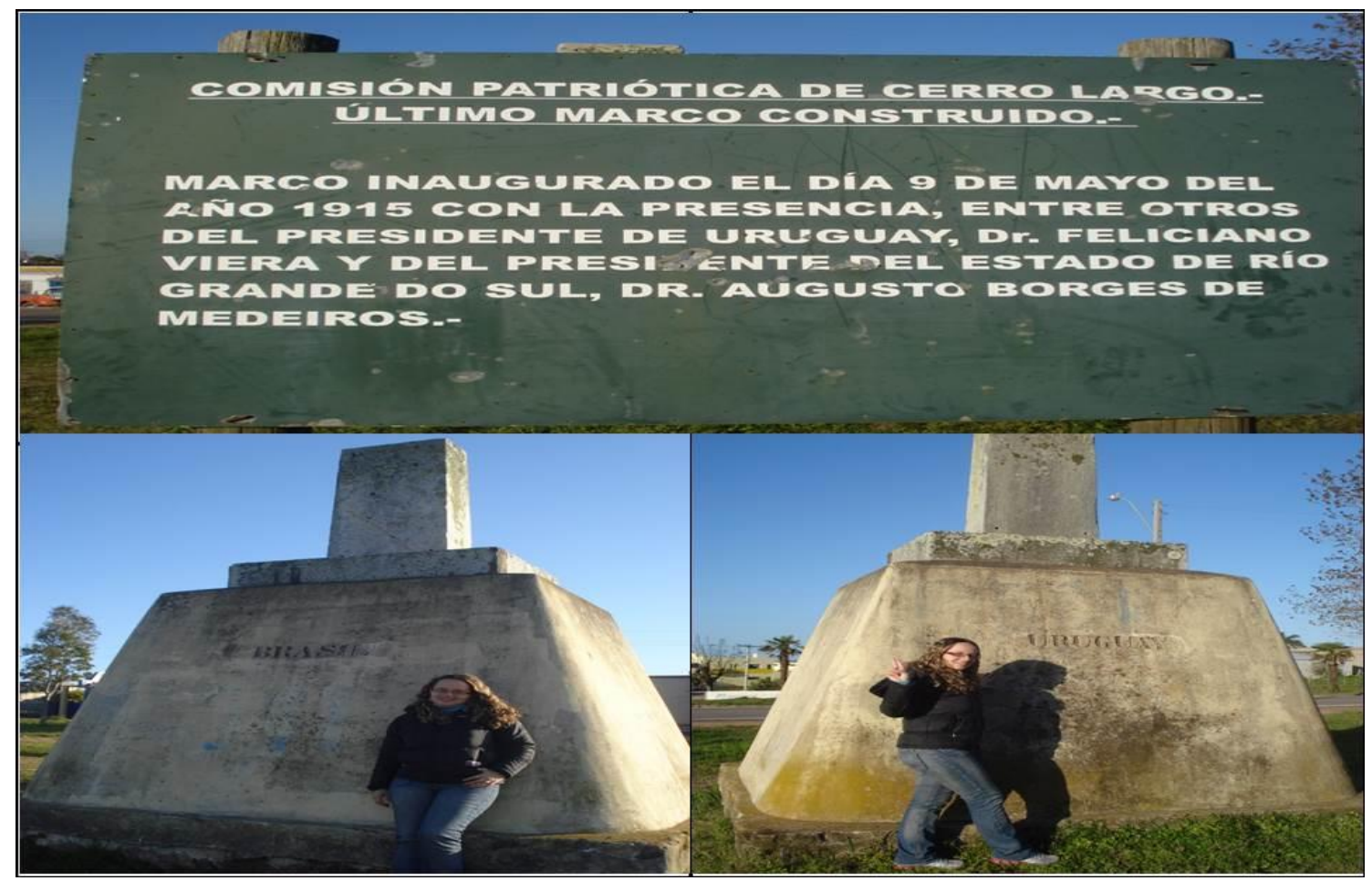

Foto 2: Último marco demarcatório em Aceguá.

Hoje, os marcos territoriais e uma avenida indicam onde acaba o Brasil e começa o Uruguai, mas os povos das duas fronteiras são bastante unidos em Aceguá. Prova disso é que essa avenida é ao mesmo tempo linha divisória e espaço de convívio pacífico entre brasileiros e uruguaios com suas culturas, esperanças e memórias partilhadas. Essa praça está localizada no limite político entre Brasil e Uruguai. Todavia, em observações in locu, não se percebe limite linguístico ou interacional, pois toda a comunidade compartilha hábitos, costumes, tradições, gastronomia e línguas, contexto em que se observa o bilinguismo social.

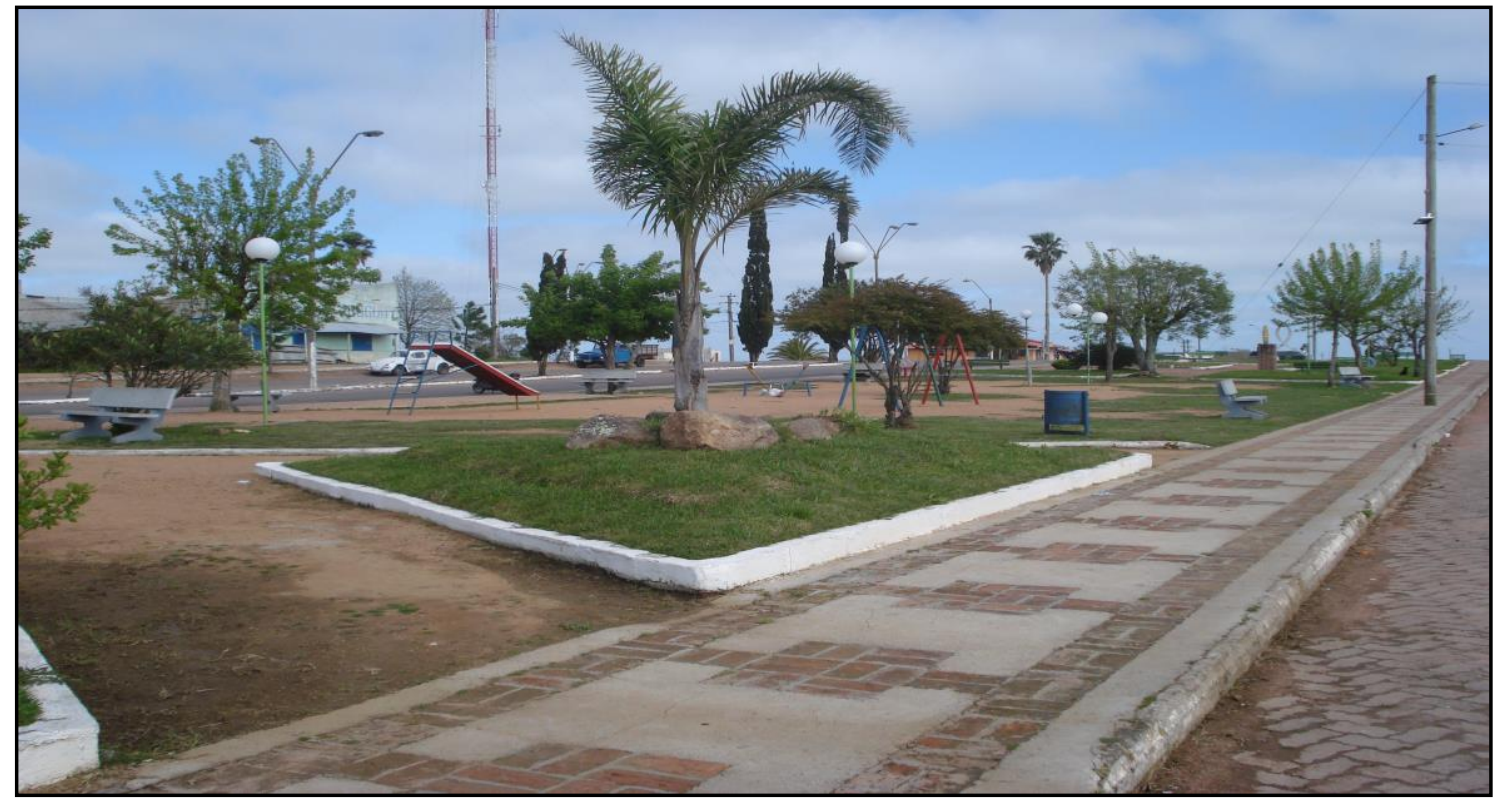

Foto 3: Praça localizada entre Brasil e Uruguai. 
Em suma, toda a linha demarcatória na zona fronteiriça até Aceguá foi autorizada por meio do tratado de limites entre Brasil e República Oriental do Uruguai.

\begin{abstract}
No Aceguá terá o Governo de desapropriar, sobre a nova fronteira, uma faixa de duas ou mais léguas para as retalhar e vender a famílias brasileiras que vão povoar a fronteira; e não a famílias ou colonos estrangeiros; porque não é com eles, nem com desertos de léguas, ou grandes estâncias que havemos cobrir ou defender a Província. E, além disto, será preciso nesse ângulo formado pelos rios Negro e Jaguarão escolher o lugar para uma Praça, que não ocupe menos de 600 homens de guarnição, para ser, por enquanto, a primeira Praça forte do Brazil (GOLIN, 2004, p. 129-130).
\end{abstract}

Nessa praça forte do Brasil, surgiria apenas Aceguá segundo um ofício reservado do Marechal do Exército Barão de Caçapava ao ministro Paranhos (Vila de São José do Norte, 31 de janeiro de 1857. Itamaraty: Brasil-Uruguai, 1852-1862, apud GOLIN, 2004, p. 130). É nítido que a colonização deveria ser feita exclusivamente por brasileiros, porque havia a ideia de defesa da fronteira. Por isso, a ocupação precisava ser feita pelos sul-rio-grandenses típicos e fronteiriços, pelos filhos naturais da terra como afirmava o barão de Caçapava (GOLIN, 2004, p. 129).

A partir de 1852, houve certa desordem na fronteira uruguaio-brasileira. Numerosos brasileiros possuíam terras no Uruguai em continuidade com as terras que tinham no Rio Grande. No entanto, a propriedade e o gado estavam ameaçados, uma vez que várias fazendas eram invadidas. Por isso, pequenos bandos começaram a cruzar as fronteiras rumo ao Uruguai para recuperar os rebanhos roubados (CALÓGERAS, 1972, p. 233-234).

Em 1858, uma força militar, sob ordens do comandante da fronteira de Bagé, entrou no território uruguaio que seria cedido ao Brasil pelo Tratado de 1851 por conta das hostilidades da fronteira (GOLIN, 2004, p. 129). Segundo o mesmo autor:

\footnotetext{
O território dessa relação abrange extensões além da linha divisória e alcança dezenas de quilômetros internos dos países limítrofes. A penetração brasileira no Uruguai foi mais facilmente observável porque se deu concretamente pela ocupação da terra e pela presença de um contingente populacional enorme, especialmente nos departamentos do norte, rivalizando demograficamente com a presença oriental (GOLIN, 2004, p. 193).
}

Com isso, confirma-se a presença de portugueses em território uruguaio na região do Aceguá, já que os terrenos de Aceguá passaram a fazer parte do território brasileiro, sem maiores problemas (GOLIN, 2004, p. 170 e 177). Segundo Rona (1963, p. 11), em 1861, uma ampla faixa do território uruguaio estava ocupada quase 
exclusivamente por brasileiros. Só depois de 1862 se inicia a migração de uruguaios até o Norte do Uruguai.

Sobre a existência de Aceguá, segundo historiadores, há mais de 50 anos já existiam famílias na região. Porém, somente em 1862 surge no parlamento uruguaio um Projeto de Lei (de Nicolás Lengua) que mostra a importância de se criar o Pueblo Juncal, posteriormente chamado Povo Almeida, uma das primeiras famílias do lugar, a partir da expropriação da terra em que se fundaria "el pueblo". Esse povoado consolidou-se por meio do convívio intenso na fronteira em 1863.

Segundo Elizaincín, Behares e Barrios (1987, p. 39), entre 1853 e 1862, o Parlamento funda uma série de povoações nesta zona com a esperança de conter a presença portuguesa. Mesmo assim, houve uma contínua interpenetração que assimilou elementos brasileiros e uruguaios. A cultura e a moeda brasileira se mantinham nessa região.

Nicolas Lengua (1862) divergia das opiniões de que Aceguá era deserta e defendia a criação de um pueblo na região, uma vez que era preciso colocar uma barreira para que os vizinhos não avançassem o limite, porque Aceguá era quase toda povoada por estrangeiros, principalmente brasileiros. Além disso, era bem localizada e já tinha vários comércios e moradores, o que reforça a necessidade política e econômica de povoamento.

De acordo com a lei de 9 de julho de 1862, artigo 1º "En la frontera de Aceguá, en la localidad más conveniente a juicio del P. E., se fundará un pueblo, sobre la área superficial de una legua cuadrada, que se denominará Juncal". Segundo o historiador Juan Carlos Pedemonte (1985), a Assembléia Geral, na sessão de 18 de abril de 1863, dispôs sobre a criação na parte uruguaia do Povo Juncal, mas nunca chegou a existir esse nome, e o local só ficou conhecido como Aceguá.

Em $1904^{7}$, Aceguá aparece nos livros de história por causa das tentativas de paz para toda essa região, que necessitava de ordem e retomada do caminho da prosperidade. $^{8}$ Esse ano foi marcado pela paz devido à desmobilização do exército revolucionário logo depois da morte do caudilho blanco Aparicio Saraiva, irmão de

\footnotetext{
${ }^{7}$ Disponível em http://www.turismoenuruguay.com.uy/informacion_turistica/informacion_turistica_masinfo.php?id=143 $\&$ secc=informacion_turistica. Acesso em 27 fev. 2012.

${ }^{8}$ Informação retirada do Relato de una vida empresarial (s/d) e de Aceguá-Yaciguay (TADÊO, s/d, p. xiv).
} 
Gurmecindo Saraiva, na Vila de Aceguá. Esse foi o último confronto civil entre Colorados e Blancos no Uruguai, chamado de Batalha de Masoller.

Por volta de 1941, a Lei no 10.101, do governo uruguaio, institui o Povo Aceguá como um núcleo de povoação situado no departamento de Cerro Largo, denominação que permanece até os dias de hoje. No entanto, somente em 1986, com a Lei 15.810, por iniciativa da Comissão de Cultura de Aceguá em contato com representantes nacionais, o Parlamento Uruguaio eleva o Povo de Aceguá à categoria de Vila, localizada no departamento de Cerro Largo 9 .

Em 1994, criou-se um consenso entre moradores e lideranças em prol da formação do novo município Aceguá, só emancipado de Bagé a partir do voto em 16 de abril de 1996 por meio da lei $n^{\circ} 10.766$, do governo brasileiro. Depois de sete anos de luta pela emancipação, a estrutura administrativa só foi concretizada em 2001, porque Bagé havia interposto uma ação judicial, sem êxito, tentando inviabilizar a emancipação de Aceguá. De acordo com Faccio (s/d), Bagé não se preocupava com Aceguá, porque dizia que esta não lhes fazia falta por ser um lugar fantasma, mas não queria perder a Colônia Nova (Município de Aceguá), que era mais desenvolvida economicamente.

Em 15 de fevereiro de 2002, institui-se uma lei municipal autorizando a criação dos símbolos oficiais do município de Aceguá (ACEGUÁ, 2010).

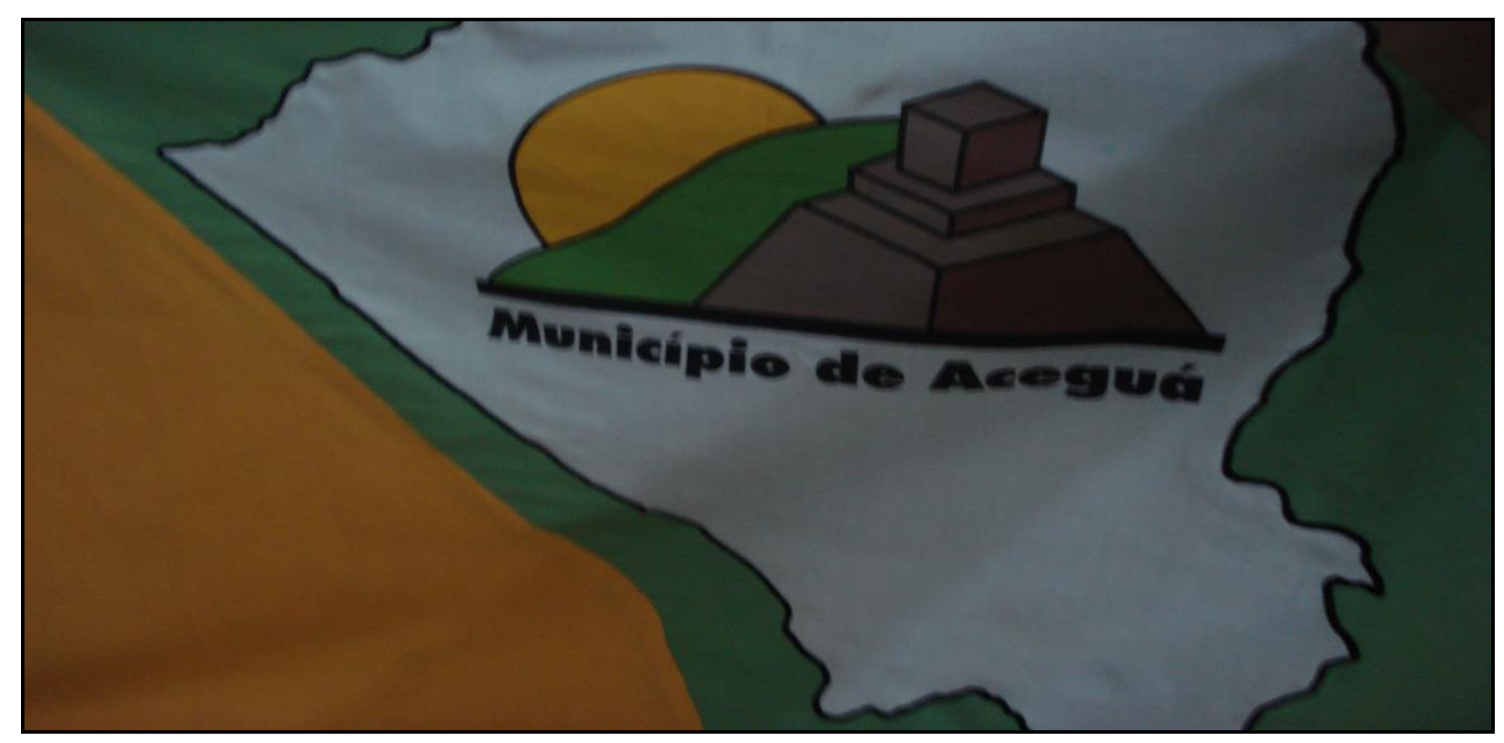

Foto 4: Símbolos de Aceguá.

9 Disponível em: http://www.acegua.rs.gov.br/portal1/municipio/historia.asp?iIdMun=100143468. Acesso em: 25 fev. 2012. 
Segundo outro documento histórico escrito pelo Engenheiro Agrônomo Julio Cezar Vinholes Pinto (s/d), havia uma necessidade de emancipação de Aceguá já que "os moradores desta vila têm na sua formação cultural uma forte influência dos uruguaios, constituindo-se praticamente uma única comunidade, como já ocorre hoje com cidades fronteiriças”. Além disso, Aceguá prosperou muito entre 1975 e 1986 com o comércio graças à desigualdade cambial entre Uruguai e Brasil. Aceguá era fonte de renda de impostos para Bagé, mas não recebia nada de investimento básico antes da emancipação (FACCIO, s/d).

Com relação à língua utilizada nessa época, Elizaincín (1992, p. 99-100), citando Pedro Varela (1964), afirma que quase todo o Norte da República falava português. Assim, Elizaincín explica que se, desde meados do século 19, era o português a língua mais falada na zona fronteiriça, seguramente era também desde muito antes. $\mathrm{O}$ espanhol era falado esporadicamente.

Desde o século XVI, a presença dos portugueses-brasileiros na fronteira era cada vez mais abundante, porque também os controles estavam dirigidos à vigilância do contrabando de gado. O estabelecimento pacífico de portugueses na zona não era impedido (ELIZAINCÍN, 1992, p. 98).

Até a metade do século XIX, a população do Uruguai era composta por $40 \%$ de brasileiros. E, até 1857, as propriedades territoriais dos brasileiros alcançavam mais de $47.000 \mathrm{~km}$ de um total de $177.508 \mathrm{~km}^{2}$ (ELIZAINCÍN, 1992, p. 99).

Por conta da presença massiva de brasileiros e do português no Uruguai desde a época colonial, a política linguística uruguaia foi centrada no monolinguismo desde 1877 a 1979. Enquanto o espanhol era valorizado, considerado a verdadeira identidade do uruguaio, e imposto por meio de políticas educacionais, o português era rejeitado (CARVALHO, 2006).

Em 1994, o Tratado do Mercosul é responsável por uma integração regional maior entre Brasil e Uruguai. De 1995-1997, há um incentivo à criação de Centros de Ensino de Língua Estrangeira no Uruguai. E apenas em 2003 a política bilíngue começa nas escolas uruguaias da fronteira. Em 2008, a Lei Geral de Educação passa a reconhecer o português como língua materna dos uruguaios (CARVALHO, 2006).

É notório, pois, que a política monolíngue de mais de um século frente à política bilíngue de pouco mais de uma década traz consequências de pouca visibilidade e aceitação do português na fronteira, apesar dessa realidade bilíngue ser bem antiga. 


\subsection{A comunidade de Aceguá}

Aceguá está localizada no extremo Sul do Rio Grande do Sul no Brasil em fronteira com o Uruguai e fica a $60 \mathrm{~km}$ do município mais próximo do Brasil (Bagé) e também do Uruguai (Melo), e a 440 km de Porto Alegre e Montevidéu.

O lado brasileiro de Aceguá é emancipado de Bagé, desde 1995, e tem como capital Porto Alegre. Aceguá-Brasil é dividida em três distritos: Distrito de Rio Negro, Distrito de Colônia Nova e Distrito do Minuano.

O lado uruguaio de Aceguá pertence ao departamento de Cerro Largo, que tem como capital Melo. O Uruguai se divide em 19 departamentos, enquanto o Brasil se divide em 26 estados e o Distrito Federal.

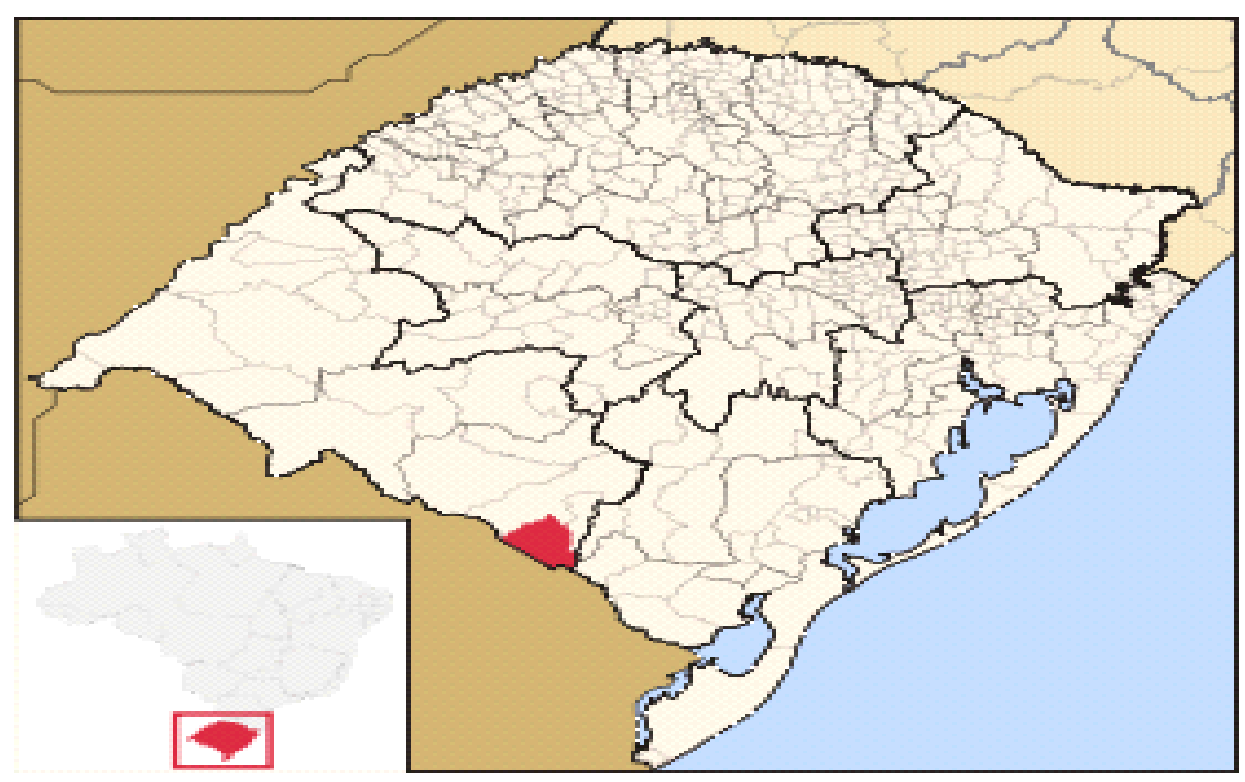

Mapa 1: Mapa de Aceguá-Brasil. ${ }^{10}$

Aceguá é uma única comunidade homônima dividida ao meio por uma linha imaginária. Assim, “Aceguá es la única frontera que sus pueblos, con diferentes idiomas, tienen el mismo nombre, la misma pronunciación y forma de escribir" (Municipio Acegua, $1^{\circ}$ de Enero del 2001).

Como não há limites físicos entre os dois países e não há acidente geográfico em Aceguá, essa ausência de delimitação também contribuiu e contribui para a interrelação entre as pessoas e o convívio intenso e pacífico entre os cidadãos de ambos os países como se pode observar na história do município.

\footnotetext{
${ }^{10}$ Disponível em: http://pt.wikipedia.org/wiki/Acegu\%C3\%A1. Acesso em: 09 nov. 2012.
} 


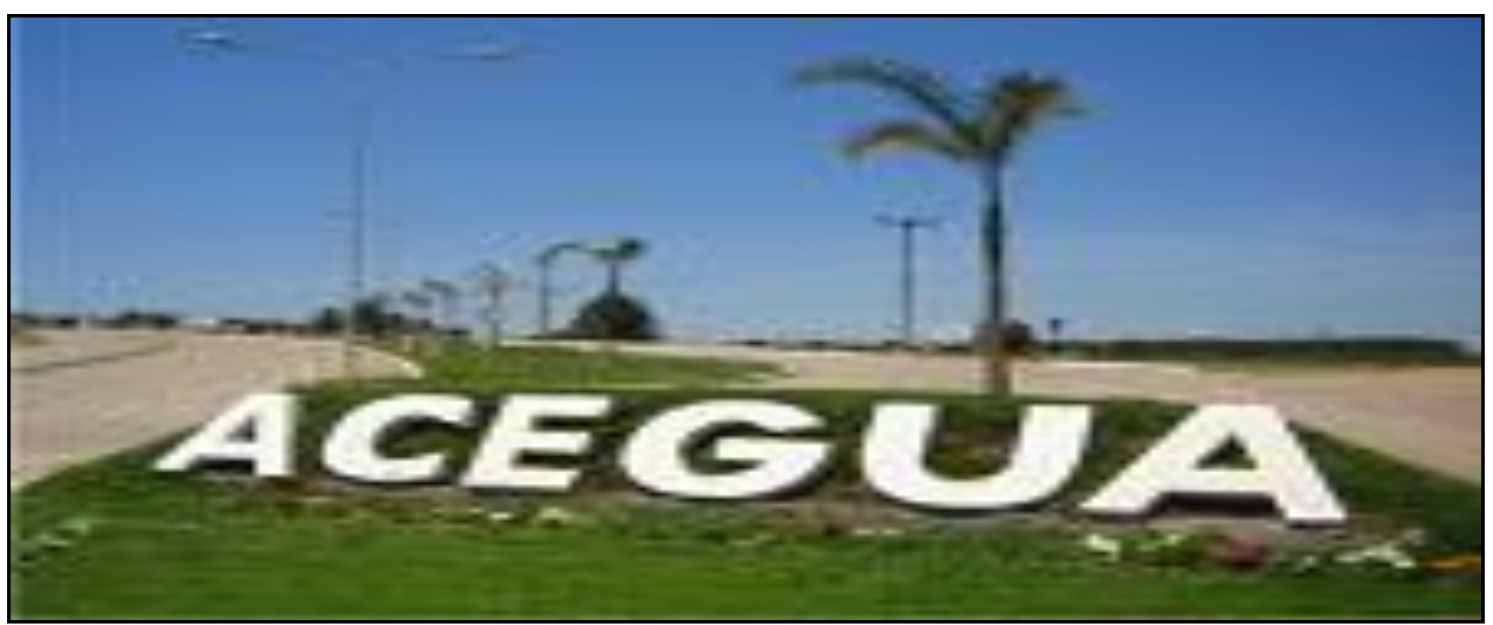

Foto 5: Entrada de Aceguá ${ }^{11}$.

Aceguá-Brasil tem aproximadamente 4.394 habitantes (2.091 mulheres e 2.303 homens). Deste total, $1.059(24,1 \%)$ pessoas são da zona urbana e $3.335(75,9 \%)$ da zona rural. Aceguá-Uruguai tem cerca de 1.432 habitantes (654 mulheres e 778 homens). Segundo o documento brasileiro oficial de Aceguá (2010), o município trabalha forte no campo, no comércio e no turismo de eventos e compras. Cerca de $80 \%$ dos municípios estão na zona rural, setor que sustenta $85 \%$ do PIB. Os entrevistados para compor nossa amostra são da área urbana, exatamente da linha fronteiriça.

A área territorial de Aceguá corresponde a 1.502, $17 \mathrm{~km}^{2}\left(1,73 \mathrm{~km}^{2}\right.$ de zona urbana e 1.500,44 $\mathrm{km}^{2}$ de zona rural), representando 0,57\% do Estado, 0,27\% da Região Sul e $0,018 \%$ de todo o território brasileiro ${ }^{12}$.

A extensão em linha de fronteira com o Uruguai é equivalente a $65 \mathrm{~km}$, com $275 \mathrm{~m}$ de altitude. Aceguá faz limite geográfico ao Norte com Bagé, ao Sul com a República Oriental do Uruguai, ao Leste com Pedras Altas, Candiota e Hulha Negra e ao Oeste com Bagé e República Oriental do Uruguai (ACEGUÁ, 2010).

Segundo Tadêo (s/d, p. II), Aceguá deriva da palavra nativa Yaciguay, de origem tupi-guarani, provavelmente dos charruas. Na tradução Guarani, significa:

(i) terra alta e fria - pela altura das elevações;

(ii) vale da lua, berço da lua ou seio da lua - por ter morros (cerros) altos;

\footnotetext{
${ }^{11}$ Disponível em: http://pampanopedal.blogspot.com.br/2010_12_19_archive.html. Acesso em 09 nov. 2012.

${ }^{12}$ Disponível em: http://www.acegua.rs.gov.br/portal1/intro.asp?iIdMun=100143468. Acesso em: 25 fev. 2012
} 
(iii) lugar de espera ou lugar de descanso (eterno) - onde os indígenas enterravam seus mortos por conta da visão panorâmica dessa região alta, próxima ao céu.

(iv) divisa, fronteira, limite, final - por se localizar na fronteira entre BrasilUruguai.

Essa origem indígena deve-se ao fato de que os primeiros habitantes de Aceguá foram índios pampas denominados Charruas, Guenoas e Minuanos, nômades que viviam da caça da ema, cervos etc. Segundo Arteaga (2008, p. 12), quando a Espanha descobre a América, a Banda Oriental já estava povoada principalmente por guaranis e charruas.

Há também uma versão folclórica e recorrente na fala dos colaboradores sobre possíveis contrabandistas castelhanos e portugueses que percorriam El camino de los Quileros com mercadorias em lombo de cavalos. Quando os quileros passavam pelos cerros, ouviam o uivo dos Sorros ou Guará (lobo pequeno) e diziam "Hay un bicho que hace guá".

Tadêo (s/d, p. xiii) também relata outra versão para o mesmo fato. Segundo ele, há uma lenda que, por volta do século XIX, o contrabando da fronteira se intensificou e começaram a aparecer os contrabandistas a cavalo, que vinham do Uruguai atrás de cachaça, erva-mate e açúcar. Nesse período, um rapaz novato entrou no bando e foi motivo de brincadeiras durante toda a viagem. Ao anoitecer, já assustado com as histórias, o rapaz ouviu um grito (guáá) de uma raposa (sorro) e saiu correndo. A partir disso, os colegas sempre falavam em tom de graça "mira que haja ahí un bicho que hace guá".

Essa versão para o nome da região retrata a formação de Aceguá como sendo também resultante da comercialização informal na fronteira, já que a fronteira seca é um caminho natural entre países limítrofes (TADÊO, s/d, p. 3). O contrabando era e ainda é uma forma de comércio muito comum na fronteira e, consequentemente, em Aceguá. Os contrabandistas, conhecidos como "quileros", atravessavam a fronteira à noite, a pé ou a cavalo. Atualmente, eles viajam em motos transportando alimentos, vestimentas e, principalmente, botijão de gás, por conta do menor preço. Ainda que essa prática possa ser repelida por pessoas de fora, é aceita por grande parte dos moradores, pois é vista meramente como um trabalho. 
Na história de Aceguá, consta que a década de 30 foi o período com muitos avanços no povoamento, tais como: telégrafo público, caixa rural, prefeitura, transporte, campeonato mundial de futebol, polícia civil, médico e farmacêutico, escolas e comércios, em grande parte do lado brasileiro. Em 1982, surge a UTU (Universidad del Trabajo del Uruguay) do lado uruguaio. Em 1986, é oficializado o primeiro meio de comunicação de massa, a Radio Integración, 101.5 FM. Em 1998, começam a funcionar as "Aduanas Integradas" entre Uruguai e Brasil (TADÊO, s/d).

Segundo o Relato de una vida empresarial (s/d), no século XIX, a saúde da população de Aceguá-Uruguai era precária, pois não havia assistência às gripes, convulsões, sarampo e difteria. Foi um período bastante difícil para a população até a chegada de alguns médicos de Montevidéu. Houve, portanto, um incentivo à migração de hispano-falantes para a fronteira, porque a política uruguaia, até então, era nacionalista e unificadora, centrada em Montevidéu.

Nesse mesmo documento, há o registro de que as rodovias foram construídas em 1935, como a linha de transporte Melo-Aceguá. Atualmente, Aceguá possui três estradas, a saber, a municipal $(528 \mathrm{~km})$, a estadual $(12 \mathrm{~km})$ e a federal $(45 \mathrm{~km})$, em um total de $585 \mathrm{~km}$.

Depois da emancipação de Aceguá-Brasil em relação a Bagé (1996), a comunidade foi beneficiada com melhores estradas, melhor estrutura urbana, postos de saúde, hospital ${ }^{13}$, transporte escolar urbano e rural e avanços na educação com a escola municipal, porque a estadual, ambas do lado do Brasil, e a escola uruguaia já existiam. Tudo isso era divulgado como sinônimo de progresso na região.

A partir de um trabalho realizado sobre a temática do desenvolvimento fronteiriço, do ponto de vista das relações internacionais, Aveiro (2006, p. 102-103) afirma que o diálogo na fronteira também se intensificou depois da emancipação e propiciou um desenvolvimento maior do município.

Em 1992, acontece o primeiro encontro binacional para o desenvolvimento da região fronteiriça Melo-Aceguá-Bagé (TADÊO, s/d). Os comitês de fronteira surgiram em 1989, mas o Comitê de Fronteira de Aceguá só se reuniu pela primeira vez em 1997 quando discutiu a transformação dos dois municípios em entreposto de comércio externo - importação e exportação, a fim de minimizar o desemprego nessa região predominantemente rural. A atuação em conjunto de bombeiros e policiais, em ambos

\footnotetext{
${ }^{13}$ Há referências de que apenas em 1943 chega a Aceguá um farmacêutico (TADÊO, s/d, p. xvi).
} 
os lados da fronteira, também foi pauta de discussão e são temas tratados na Nova Agenda de Cooperação e Desenvolvimento Froteiriço (AVEIRO, 2006, p. 69).

Essas medidas de integração fronteiriça confirmam a vivência pacífica entre os dois povos. Até hoje, percebe-se que essas instâncias são integradas no sentido de uma cooperação mútua entre os profissionais que trabalham na região fronteiriça. De fato, a rua que separa Brasil e Uruguai em Aceguá ou o registro da nacionalidade dos moradores não divide duas comunidades, mas sim as integra de forma identitária, social, cultural e até mesmo linguística. Isso não quer dizer que tudo seja semelhante nos dois lados da fronteira, mas é, de certa forma, bem complementar.

Apesar de toda essa melhoria, houve vários contratempos. Muitos colaboradores relataram que a fronteira decaiu depois da emancipação, porque quase todos os moradores que viviam do comércio para os uruguaios foram à falência. Com a nova legislação, a fiscalização passou a ser mais acirrada e o comércio internacional da fronteira se extinguiu. Hoje, o comércio municipal é apenas voltado para o freeshop na parte do Uruguai e os turistas somente entram em Aceguá-Uruguai para fazerem as compras lá. Por isso, os moradores reclamam da falta de turismo e incentivo para a divulgação da cultura e o aumento do comércio local.

Como já foi dito, do lado do Brasil, o município de Aceguá (sede) é composto por três distritos: Distrito de Rio Negro, Distrito de Colônia Nova e Distrito do Minuano. Os distritos se organizam da maneira apresentada no Mapa $2^{14}$ :

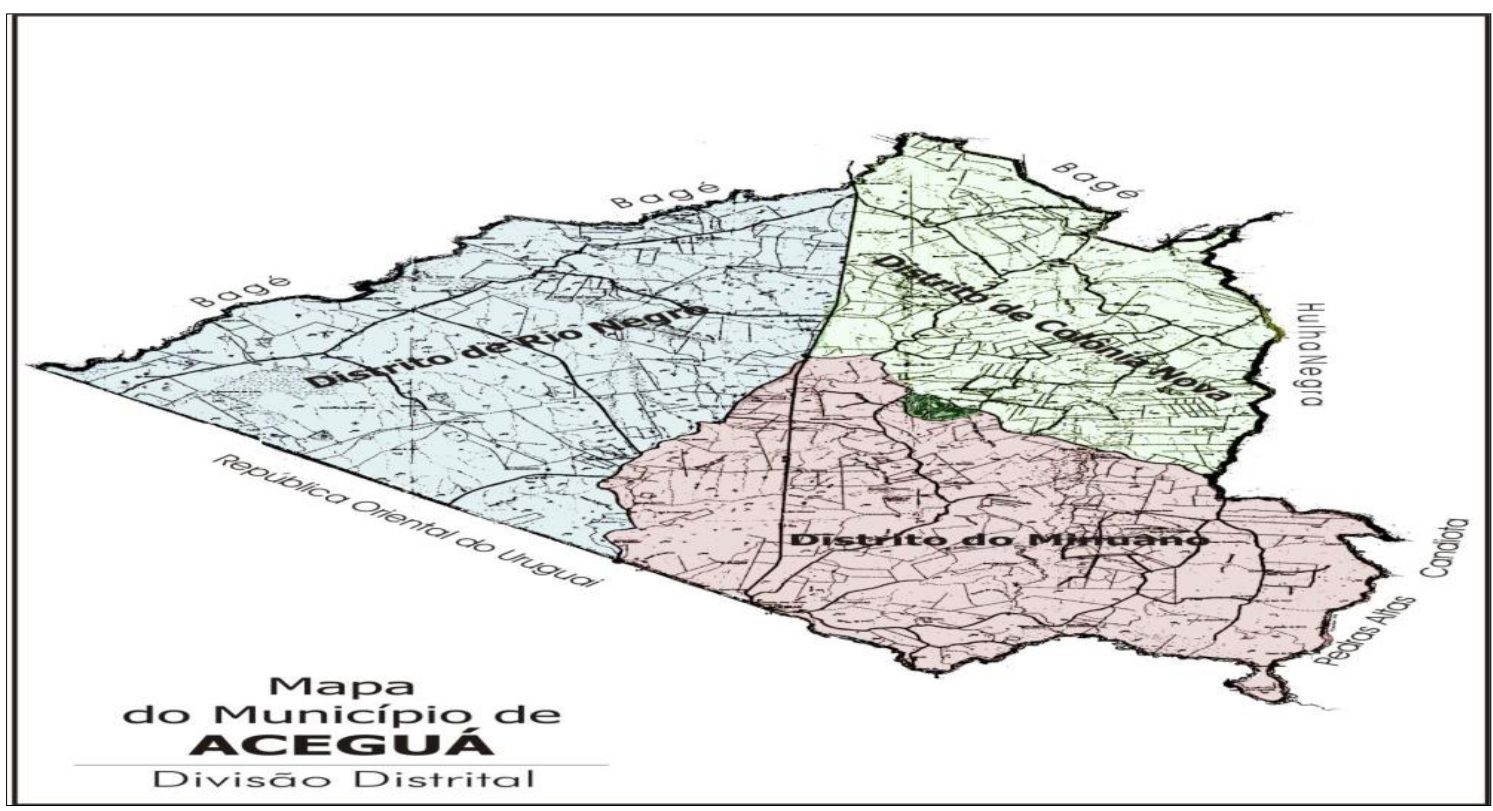

Mapa 2: Mapa da divisão distrital de Aceguá-Brasil. ${ }^{15}$

\footnotetext{
${ }^{14}$ As informações sobre os distritos foram retiradas de folderes e documentos sem referência da Prefeitura Municipal de Aceguá.
} 
O Distrito de Rio Negro tem um rio denso que banha integralmente a paisagem e avança o Uruguai até chegar ao Rio Uruguai, que juntos alcançam o Rio da Prata. Esse distrito colabora na criação de gado de diversas raças europeias para disputarem o mercado mundial da carne, além da produtividade das lavouras de arroz.

O Distrito de Colônia Nova situa-se a $50 \mathrm{~km}$ da cidade de Bagé e a $35 \mathrm{~km}$ da sede do Município de Aceguá. Primeiramente, os imigrantes germânicos, denominados menonitas, que estavam na Rússia em fevereiro de 1930, estabeleceram-se na região oeste de Santa Catarina, constituindo a Colônia Krauel. Em 1949, por iniciativa do Governo do Estado, foi fundada a Comunidade Colônia Nova dos alemães que chegaram a Aceguá com interesses em adquirir terras para cultivo de trigo ${ }^{16}$.

Couto (2009, p. 168) descreve o caminho percorrido pelos menonitas até chegar ao Sul do Brasil. Segundo o autor, os menonitas surgiram do movimento anabatista/protestante na Suíça, em 1525, deslocando-se para os países Baixos devido a perseguições religiosas. O nome "menonitas" refere-se a Menno Simons, um de seus líderes.

Em 1930, alguns vieram para o Brasil, instalando-se no vale do rio Krauel (Witmarsum) e no chapadão do "Stolzplateau", Santa Catarina. Em 1934, parte do grupo migrou para Curitiba, parte para Blumenau, parte para São Paulo. Em 1948, um subgrupo instalou-se na "Colônia Nova", próximo a Bagé (RS) (COUTO, 2009, p. 168).

O anabatismo foi um movimento religioso protestante radical do período da Reforma Protestante do século XVI na Europa. Diante das perseguições, se refugiaram também no Brasil e em Aceguá (lado brasileiro) ${ }^{17}$.

Em 1956, foi fundada a Cooperativa Mista de Aceguá Ltda. Posteriormente, a pecuária leiteira também foi integrada à agricultura, incentivada pelo governo, tendo em vista a queda na produção de trigo por problemas de ordem econômica e climática. Portanto, inaugura-se em 1960 a fábrica de laticínios, que serviu para ampliar a criação de gado leiteiro e o plantio de forrageiras.

A Colônia Nova possui escolas comunitárias, associações e cooperativas, entre as quais se destaca a CAMAL (Cooperativa Agrícola Mista Aceguá Ltda), criada em

\footnotetext{
${ }^{15}$ Disponível nos documentos oficiais de Aceguá.

${ }^{16}$ Disponível em http://www.terragaucha.com.br/imags_acegua.htm. Acesso em 25/02/12.

${ }^{17}$ Disponível em http://monergismo.com/raniere/anabatismo-o-movimento-mais-radical-e-maisperseguido-da-reforma-protestante. Acesso em 25 fev. 2012.
} 
1961. O povoamento alemão contribuiu significativamente para o desenvolvimento do município, com a maior industrialização do leite e seus derivados do Rio Grande do Sul.

A partir da década de 70, a Colônia Nova também começou a exportar matrizes da raça holandesa, a produzir sementes, arroz irrigado, sorgo, trigo, cevada, milho, cornichão para os bovinos, entre outros.

Esse distrito de Aceguá tem um museu, igrejas, escolas e o único hospital da região. Com o aumento da população da Colônia Nova, foi fundada, entre 1970 e 1971, a nova Colônia Presidente Médici, com 45 propriedades rurais. Em 1998 e 1999, formou-se a Colônia Pioneira com 80 propriedades rurais.

O Distrito do Minuano se destaca pela presença de novos projetos e alternativas de ocupação do solo pródigo, por meio da cultura de sorgo, milho, leite e gado de corte.

$\mathrm{Na}$ agropecuária, há o fortalecimento da bovinocultura de leite, bovinocultura de corte, ovinocultura, criação de cavalos crioulos e produção de trigo e arroz. A economia é favorável ao Brasil, porque é o local de melhor gado e pastagem por ter o solo de excelente qualidade e os campos bastante férteis. Aceguá possui aduanas integradas que sustentam o fluxo de importação e exportação, principalmente de carne e arroz.

Em termos territoriais, do lado do Uruguai, a extensão é bem menor e não há divisões distritais. A parte uruguaia não é emancipada e pertence a Melo, capital de Cerro Largo. Há os serviços gerais como água corrente, luz elétrica, telefone, telégrafo, coleta de lixo, banco, agência de correio, hotel, escola de ensino fundamental e médio, UTU (Universidade Tecnológica do Uruguai), policlínica. Na parte recreativa, há parques, quadra de basquetebol e futebol, centro social, pista de atletismo, rádio difusora local. Na parte de transporte, ônibus de linha local, interdepartamental e internacional. Além disso, também há polícia, subcomissária e aduana ${ }^{18}$.

Do lado do Brasil, na parte hospitalar, existem dois postos de saúde (um na sede e outro em Colônia Nova) e um hospital em Colônia Nova. Há aproximadamente 152 empresas comerciais, 1.045 estabelecimentos rurais e quatro indústrias. No tocante ao policiamento, existe um posto policial, uma delegacia da inspetoria veterinária e uma delegacia de polícia, todos localizados na sede do município. Também há agências bancárias, correio, cartório, posto de combustível, dois hotéis, restaurantes e diversificado comércio típico da fronteira.

\footnotetext{
${ }^{18}$ Disponível em www.ine.gub.uy. Acesso em 03 mar. 2012.
} 
Sobre a educação em Aceguá, há duas escolas municipais infantis e de ensino fundamental, três escolas municipais de ensino fundamental até $5^{a}$ série, uma escola estadual de ensino médio, Barão de Aceguá, e duas escolas estaduais de ensino fundamental. A maioria dos jovens estão na escola (82\%) e são alfabetizados (92\%). Não há universidade pública ou particular em Aceguá, somente em Bagé, a 60 quilômetros.

As relações de parentesco são bem integradas, pois o casamento entre brasileiros e uruguaios é bastante comum. Nesse sentido, a nacionalidade também é bastante complexa, e os moradores, em grande maioria os uruguaios, com dupla nacionalidade, são conhecidos como "doble chapa". Esse termo é uma analogia aos carros da região que têm placa dupla para circular livremente por ambos os territórios.

A legislação uruguaia permite que toda mãe uruguaia registre seu filho como uruguaio mesmo que a criança tenha nascido no Brasil. Depois, o cidadão pode requerer a nacionalidade brasileira. Assim, os moradores podem estudar, trabalhar e possuir documentos em ambas as regiões. Até mesmo as pessoas que não têm duplanacionalidade não encontram obstáculos para se inserirem ou trabalharem tanto no Brasil quanto no Uruguai, apesar de não serem legalizadas.

A etnia aceguaense é bastante rica e diversificada, por ser formada por brasileiros, uruguaios, descendentes de espanhóis, portugueses, indígenas, afrodescendentes e ainda por ter recebido a colônia alemã e imigração árabe. Tudo isso compõe o gaúcho ou el gaucho da fronteira. Segundo Abreu (1998, p. 193), "Na formação do rio-grandense entraram, sobretudo, açorianos, nortistas, principalmente de São Paulo, e não poucos espanhóis imigrados ou incorporados. Sobretudo na fronteira meridional deu-se a penetração das duas línguas".

Sobre os símbolos culturais da região, encontram-se referências ao Cavalo de Pedra que fica no Cerro dos Quietos, localidade de Mina do Aceguá. Esse local é o ponto mais alto do município, que está a 276 metros acima do nível do mar. É uma espécie de mirante, onde se visualiza toda a cidade ${ }^{19}$.

\footnotetext{
19 Disponível em http://www.acegua.rs.gov.br/portal1/intro.asp?iIdMun=100143468. Acesso em 25 fev. 2012.
} 


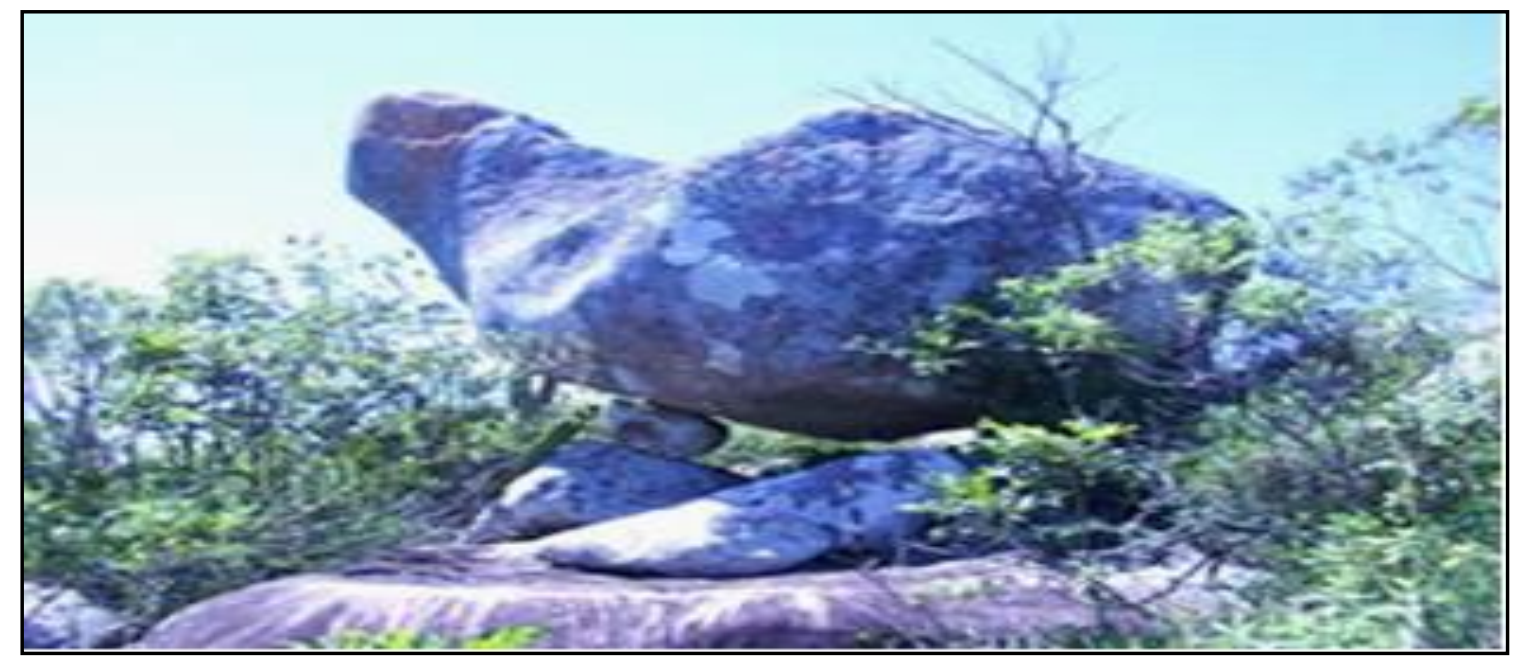

Foto 6: O cavalo de pedra em Aceguá.

Os principais eventos de Aceguá durante o ano são: rodeio (janeiro), carnaval da integração (fevereiro), campeonato de cross country e semana do município - festa campeira (abril), festa junina (junho), semana Gaspar Silveira Martins (agosto), projeto interferências, semana farroupilha e caminhada cívica (setembro), festival de cometas e pandorgas (outubro), Gaspar Silveira Martins (novembro) e natal do pampa (dezembro).

Os rodeios acontecem em janeiro, tendo como pano de fundo a tradição do sul. Outra festa cultural importante no município é a semana farroupilha, marco cultural de resistência e autoestima típica em toda a região do Sul, que acontece em setembro de cada ano e mobiliza ambos os lados da fronteira em prol da preservação e divulgação da cultura gaúcha.

A Semana Farroupilha recorda o ano de 1835, quando explode no Brasil a Revolução Farroupilha, que durou 10 anos. Os componentes eram estancieiros ordenados por Bento Gonçalves. O sentimento era de liberdade e independência do estado. Atualmente, há atividades gerais como palestras, apresentações culturais, piquetes, cavalgada final. Para marcar o início e o término da Semana Farroupilha, os moradores de Aceguá acendem uma tocha e apagam-na no fim. 


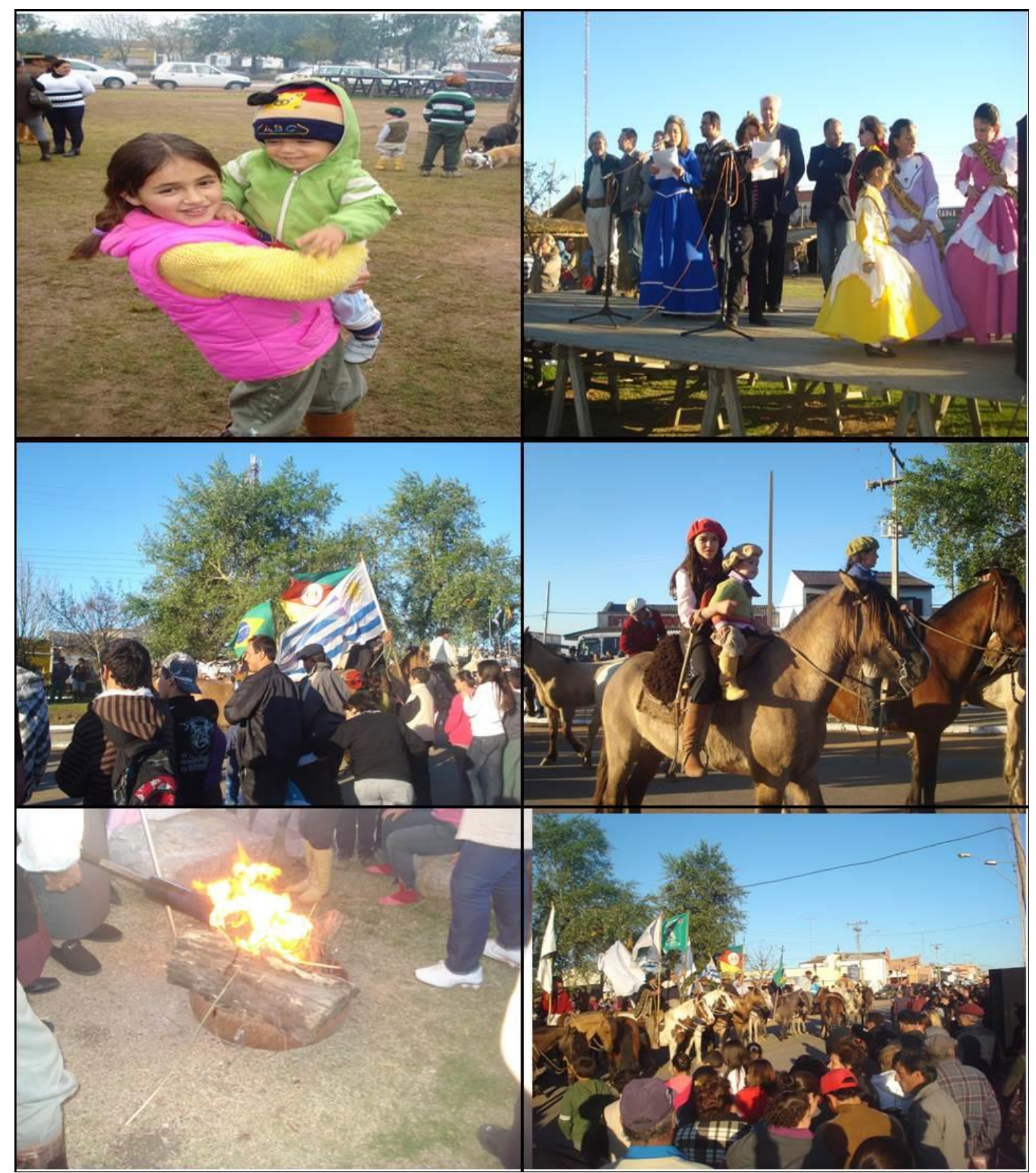

Foto 7: Semana Farroupilha na praça Caco Blanco em setembro de 2011.

Os piquetes surgiram na época das demarcações da fronteira e serviram como uma barreira militar na fronteira Brasil-Uruguai. Foram também os incorporadores da missão brasileira. "Os piquetes de cavalaria e infantaria que davam sustentação logística à Comissão de Demarcação realizavam a escolta e efetuavam os trabalhos limítrofes, a exemplo da edificação dos marcos" (GOLIN, 2004, p. 188). Atualmente, são conhecidos por piquetes as divisões das barracas na Semana Farroupilha. 


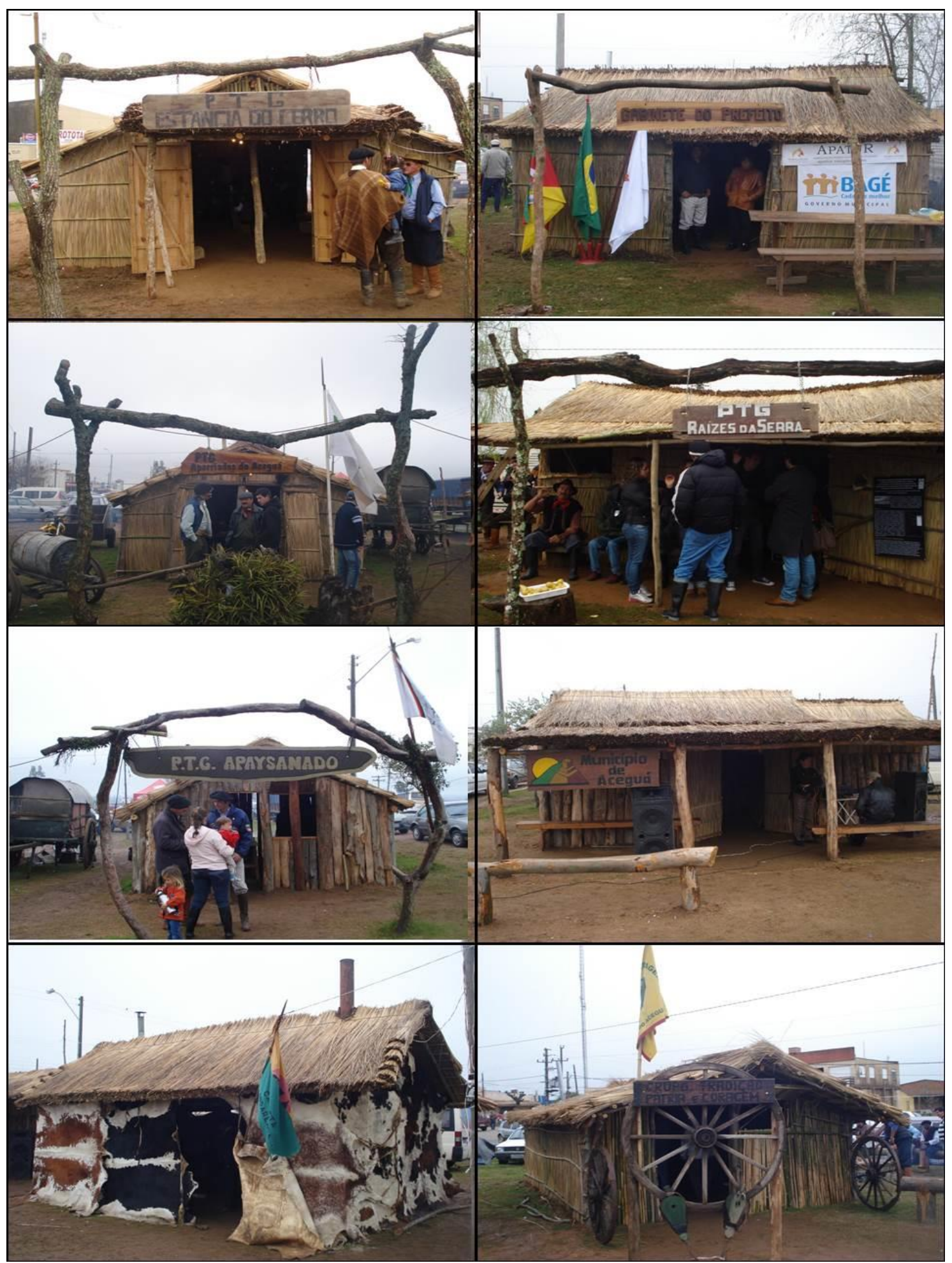

Foto 8: Piquetes da Semana Farroupilha de Aceguá em setembro de 2011.

Sobre os aspectos geográficos da região fronteiriça de Aceguá, existem a flora, com umbus, cinamomos, bosques, avenidas, matas, e a fauna, com os bem-te-vis, sabiás, joões de barro, garças, emas, lebres, cavalos crioulos. O céu é limpo e o chão preservado, com os históricos paredões, o relevo cerro dos quietos, o arroio da Mina 
(principal rio), a praça "Caco Blanco" e a Casa de Pedra. Tudo isso ajuda a compor o belo quadro paisagístico da região.

O clima é variado e bem definido nas quatro estações, com temperatura úmida. A presença do vento sul e sudoeste é constante (minuano e/ou pampeiro). As geadas são comuns no inverno e a média da estação é entre 30 a 33 geadas. As temperaturas extremas variam entre $-5^{\circ} \mathrm{C}$ e $38^{\circ} \mathrm{C}$ (TADÊO, p. III, s/d).

O relevo é caracterizado por território uniforme e ondulado ao norte, denominado de coxilhas, que variam entre 200 e 250 metros de altitude. Destaca-se a coxilha seca (divisor de águas). Predomina no ambiente o Serrado Aceguá com 324 metros no seu ponto mais elevado e com aproximadamente $40 \mathrm{~km}$ de extensão. A maior parte da serra está (hoje) do lado uruguaio da fronteira (TADÊO, p. III-IV, s/d).

No geral, Aceguá é uma comunidade pequena e totalmente integrada de ambos os lados da fronteira. Várias práticas culturais são compartilhadas e, sobretudo, respeitadas por todos. Por isso é tão difícil para um turista saber onde começa e termina Aceguá-Brasil e Aceguá-Uruguai. Até mesmo os moradores têm dificuldade em se identificar como brasileiros e/ou uruguaios, por se considerarem parte de um mesmo povo. Essa interação, agora do ponto de vista sociolinguístico, será analisada no próximo capítulo.

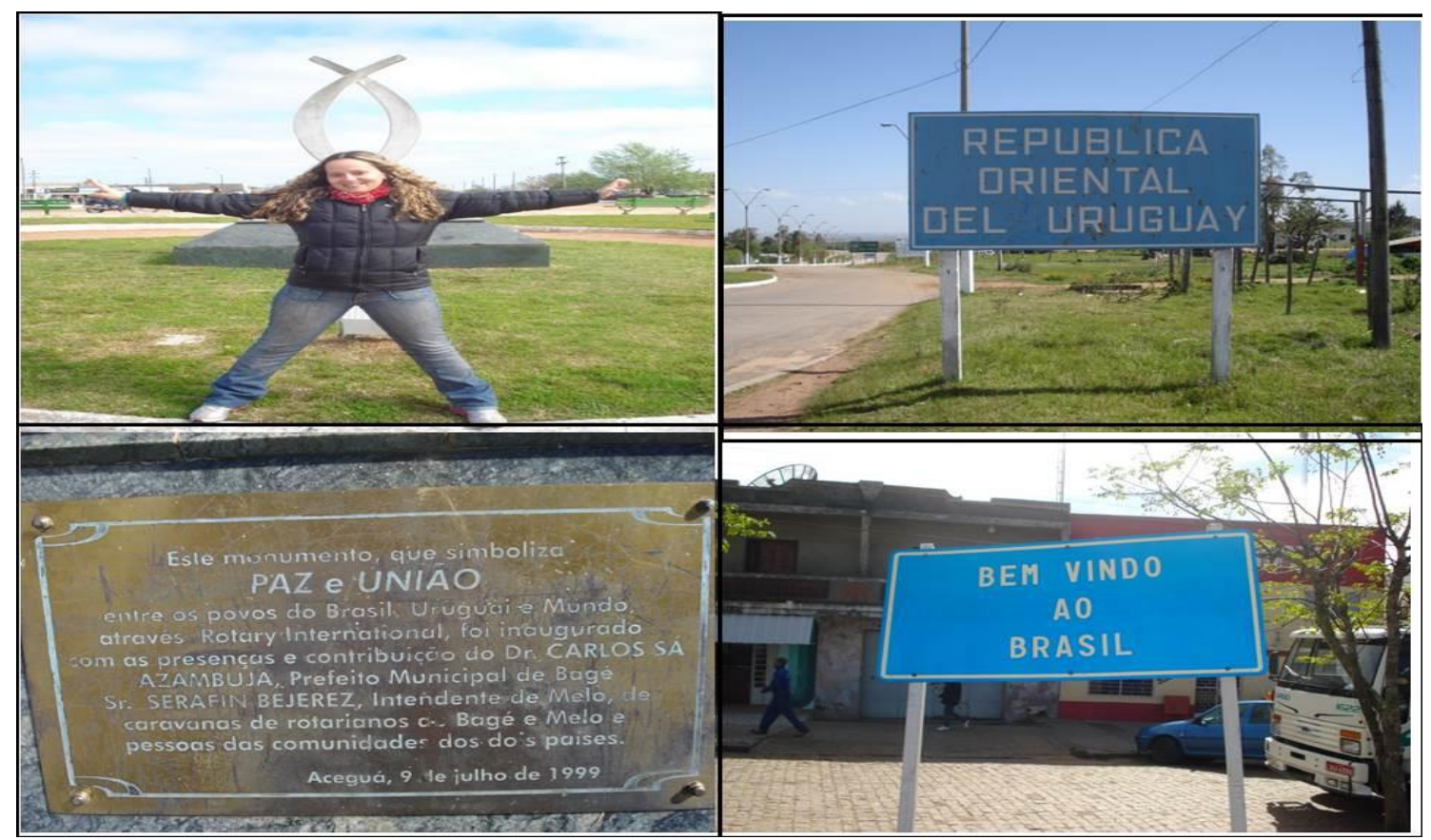

Foto 9: Símbolo de paz e união entre os povos e das placas do Uruguai e Brasil 


\title{
CAPÍTULO 2 - CONTATO LINGUÍSTICO NA FRONTEIRA DE ACEGUÁ (BRASIL- URUGUAI)
}

\begin{abstract}
Um dos condicionamentos universais da mudança parece estar operando aqui: em situações de contato, as fusões se expandem em detrimento das distinções (Herzog, 1965, p. 211). No entanto, se quisermos aplicar nossa perspicácia linguística para predizer tais fusões, precisamos antes reconhecer que a existência de dialetos heterogêneos é a forma comum, até mesmo normal, do sistema linguístico. Nem todo linguista está disposto a fazer isso.
\end{abstract}

(LABOV, 2008, p. 345)

Labov (2008, p. 345) repete a previsão feita por Herzog e afirma que em situações de contato as fusões se expandem em detrimento das distinções. Esse também é o princípio da convergência linguística (POPLACK, 1993, p. 256), ou seja, os falantes tendem a utilizar formas em comum nas duas línguas. Silva-Corvalán (1994) explica que a necessidade de "economizar espaço cognitivo" na mente do bilíngue leva à convergência, hipótese ainda a ser provada.

A hipótese da convergência funcional é a especificação de um conjunto comum de recursos compartilhados pelas categorias funcionais equivalentes nas duas línguas, faladas por um indivíduo bilíngue, que ocorre em uma situação de contato quando um conjunto de características é instável ou uma nova categoria funcional surge devido ao input de uma língua que é compatível com o input de outra língua (MUYSKEN, 2013, p. 158 ).

Para Silva-Corvalán (1994, p. 115), o contato linguístico manifesta-se não exclusivamente como a transferência da língua de contato, mas em fenômenos como a simplificação de alternativas, a aquisição seletiva, ou congelamento da competência alcançada em uma determinada idade. Todas estas estratégias convergem no sentido de aliviar a carga de ter de se lembrar e usar dois sistemas linguísticos diferentes. O contato linguístico também tem o efeito de acelerar a difusão das mudanças linguísticas quando já há uma tendência na língua de mudança em certa direção (SILVA-CORVALÁN, 1994, p. 92).

A convergência tende a ocorrer em situações multilíngues em que as funções de linguagem são marcadores salientes da identidade de um grupo étnico, mas há a necessidade de comunicação inter-grupal (GARRETT, 2006, p. 56). No entanto, este princípio não explica o que acontece em Aceguá, porque a gente já adquiriu status de 
pronome de primeira pessoa do plural também no português uruguaio de Aceguá da mesma forma que no português brasileiro geral e no português brasileiro de Aceguá como ilustra o Quadro 1.

Quadro 1: Distribuição de nós, nosotros e a gente no espanhol, no português brasileiro e no português uruguaio

\begin{tabular}{|l|l|l|l|}
\hline & \multicolumn{1}{|c|}{$\begin{array}{c}\text { Monolíngue em } \\
\text { espanhol }\end{array}$} & \multicolumn{1}{|c|}{$\begin{array}{c}\text { Monolíngue em } \\
\text { português (PB) }\end{array}$} & \multicolumn{1}{|c|}{$\begin{array}{c}\text { Bilíngue em } \\
\text { português e } \\
\text { espanhol (PU) }\end{array}$} \\
\hline Nós & Não existe & $1^{\text {a }}$ pessoa do plural & $1^{\text {a }}$ pessoa do plural \\
\hline Nosotros & $1^{\mathrm{a}}$ pessoa do plural & Não existe & Interferência \\
\hline A gente & $\begin{array}{l}3^{\mathrm{a}} \text { pessoa do singular } \\
\text { (la }(\mathrm{s}) \text { gente(s) }\end{array}$ & $1^{\mathrm{a}}$ pessoa do plural & $1^{\mathrm{a}}$ pessoa do plural \\
\hline
\end{tabular}

Essa inovação pronominal no português uruguaio, até então não identificada por outros pesquisadores, realça uma distinção entre o espanhol e o português falados pelos bilíngues na fronteira de Aceguá, já que no espanhol não há a presença de a gente gramaticalizado como primeira pessoa do plural, mas apenas com seu sentido lexical.

A utilização de a gente pode ser um indício de uma sobreposição da identidade brasileira e, portanto, do português brasileiro. Além disso, o espanhol e o português não são línguas mutuamente ininteligíveis, e talvez por esse motivo não haja de fato a necessidade da convergência linguística para o entendimento entre as comunidades, ainda que a gente no português (pronome) seja diferente de la gente (sintagma nominal) no espanhol. Não se pode esquecer a origem comum das duas expressões e o traço de indefinitiude que ainda carrega a gente pronominal.

Para Poplack (apud SANKOFF, 2002, p. 17), quando os membros da comunidade usam regularmente as duas línguas, a convergência não é consequência necessária, o que de fato acontece com o português uruguaio falado em Aceguá, uma vez que os uruguaios utilizam as duas línguas, espanhol e português.

Esse contato linguístico é parte do tecido social da vida cotidiana de milhões de pessoas no mundo todo. As diferenças sócio-históricas por que passou e ainda passa uma comunidade bilíngue em contexto de contato linguístico são distintas de uma comunidade monolíngue, porque a variabilidade também é maior naquela comunidade do que nesta (SANKOFF, 2002, p. 1). No entanto, não há estudos que demonstrem quantitativamente que os dialetos em contato apresentem mais variação que os equivalentes monolíngues. 
O reconhecimento da variabilidade linguística no português uruguaio também é uma premissa para os estudos variacionistas, o que desfaz toda a ideia de língua "mista" ou qualquer outra classificação, ou seja, um estudo variacionista descarta, a priori, a ideia de sistema misto ou aleatório, porque demonstra justamente a sistematização linguística e social da língua. O fato de duas ou mais línguas estarem em contato não quer dizer que as línguas se manifestem de forma aleatória, pois a variação e a mudança linguística estão presentes tanto em dialetos bilíngues como monolíngues.

Primeiramente, é interessante diferenciar as línguas de contato das línguas em contato. As línguas de contato são as línguas que historicamente surgiram das situações de contato de duas línguas, dando surgimento a uma nova língua, como os pidgins e crioulos. Já as línguas em contato são línguas que permanecem em contato durante muito tempo sem sofrer grandes interferências mútuas a ponto de se transformarem em uma nova língua.

Couto $(1996,2002,2003)$ define pidgins como línguas criadas pela necessidade de comunicação entre pessoas que falam idiomas mutuamente ininteligíveis e, por isso, os pidgins apresentam estrutura sintática simplificada, ausência de morfologia, e léxico da língua dominante. Os crioulos seriam os pidgins adquiridos como língua materna ou língua de uma comunidade a partir de novas funções comunicativas. Assim, pidgin e crioulo seriam exemplos de línguas de contato. Para Garrett (2006, p. 48):

\begin{abstract}
As línguas de contato são definidas como aquelas línguas ou variedades linguísticas conhecidas historicamente por terem emergido de situações de contato social, de variadas durações e níveis de intensidade, entre falantes de duas ou mais línguas previamente existentes. Tipicamente (como visto acima), as semelhanças entre uma determinada língua de contato e uma ou mais de suas línguas de origem podem ser prontamente identificadas - no léxico ou em subsistemas gramaticais específicos, por exemplo. A língua de contato não é mutuamente inteligível de forma completa por qualquer das línguas pré-existentes, porém ela é usada dentro de alguma comunidade de falantes na qual um grupo ou subgrupo autônomo de normas para seu uso também emergiu. A língua de contato é, portanto, suficientemente distinta das línguas de origem para ser considerada de forma mais ou menos não problemática - nos aspectos estruturais, históricos e etnográficos, se não necessariamente nos aspectos políticos e ideológicos - como um código distinto (Tradução nossa) ${ }^{20}$.
\end{abstract}

20 "Contact languages will be defined here as those languages and language varieties, of varying degrees
of stability and historical depth, that are known historically to have emerged from situations of social
contact, of varying durations and degrees of intesity, among spearkers of two or more previously existing
languages. Typically (as seen above), similarities between a given contact language and one or more of its
source languages can readily be identified - in the lexicon or in particular grammatical subsystems, for
example. The contact language is not fully mutually intelligible with any of these pre-existing languages,
however, and is used within some community of speakears (broadly conceived) in which an autonomous
set or subset of norms for its use has also emerged. The contacto language is thus sufficiently distinct 
Ainda segundo Garrett (2006, p. 48), o contato linguístico ocorre quando e onde dois ou mais grupos humanos com diferentes línguas - e, na maioria dos casos, também com diferentes culturas e visões do mundo - se encontram mutuamente e se esforçam na tentativa de empreender uma comunicação linguística, independentemente de como esses encontros aconteceram, ou seja, se foram intencionais ou não, transitórios ou duradouros, simétricos ou assimétricos, pacífico ou coercivo etc. Esse tipo de contato é o que estamos chamando de línguas de contato.

Por isso, é muito mais comum os casos em que as línguas envolvidas se influenciam em diferentes graus, mas não dão origem a códigos distintos, como é o caso da fronteira de Aceguá. O bilinguismo e o multilinguismo, portanto, são os resultados mais comuns no contato de línguas, do que propriamente o surgimento de outra língua (GARRETT, 2006, p. 53). Esse tipo de contato é o que estamos chamando de línguas em contato.

As mudanças induzidas por contato geralmente não criam novos códigos distintos e grande parte delas se dá por motivações sociais (GARRETT, 2006, p. 55). E as causas do contato linguístico são múltiplas, como: estrutural, histórica, demográfica, político-econômico, social, cultural, ideológica (GARRETT, 2006, p. 66).

Thomason (2008, p. 1) vê que os fatores sociais têm primazia sobre os linguísticos na previsão de mudança induzida por contato, mesmo porque ninguém ainda comprovou com sucesso restrições linguísticas absolutas sobre a mudança induzida pelo contato. Segundo a autora (THOMASON, 2008, p. 51), há, portanto, possibilidades e não probabilidades de alguma mudança acontecer.

Nesse sentido, a história sociolinguística dos colaboradores, e não a estrutura de sua língua, determina o resultado linguístico do contato linguístico. Isso também não quer dizer que as situações de contato induzem aos mesmos tipos de mudanças, mesmo que as histórias das comunidades sejam semelhantes. Para Thomason (2008, p. 49), as condições podem ser necessárias, mas não suficientes para as mudanças, ou seja, não se pode prever quando ou se a mudança vai ocorrer, mesmo em contato linguístico. Portanto, não há negação do papel dos fatores linguísticos para a teoria da mudança linguística, mas as evidências do contato linguístico mostram que eles são facilmente

from its source languages to be regarded more or less unproblematically - on structural, historical, and ethnographic grounds, if not necessarily on political and ideological grounds - as a discrete code" (GARRETT, 2006, p. 48). 
substituídos quando há fatores sociais que conduzem para determinada direção (THOMASON, 2008, p. 43)

O contato linguístico tem sido estudado há seis décadas, e teve como precursor Uriel Weinreich (1953). Várias questões foram abordadas como bilinguismo e multilinguismo, interferência fônica, gramatical e lexical, aspectos socioculturais, métodos de pesquisa. Depois de 12 anos, Rona (1965) descobre, por acidente de percurso, um falar diferente na fronteira entre Brasil e Uruguai. Começam, então, os estudos fronteiriços no norte do Uruguai, que envolvem a questão do contato linguístico entre o português e o espanhol.

Garrett (2006, p. 53) relembra Ferguson sobre o conceito de diglossia, que é justamente o bilinguismo estável, social, envolvendo dois códigos que são historicamente relacionados, mas hierarquicamente diferenciados por domínio e função. Assim, o que estamos discutindo nesse trabalho se refere às línguas, espanhol e português, em contato na fronteira Brasil-Uruguai em contexto bilíngue, principalmente do lado uruguaio. Há também certa estratificação social desses idiomas, com o espanhol sendo preferido pelas classes mais altas e o português pelas mais baixas do lado uruguaio.

\subsection{Precursores do contato linguístico na fronteira Brasil-Uruguai}

Um dos primeiros estudiosos das línguas em contato é Uriel Weinreich (1953), que iniciou as pesquisas enfatizando o termo "contato", no livro Languages in contact. Por isso, é importante registrar os principais conceitos sobre essa área de estudo, que certamente é a base teórica para os estudos fronteiriços posteriores, inclusive este.

Para Weinreinch (1953, p. 1), duas ou mais línguas estão em contato se são usadas alternadamente pelas mesmas pessoas. O uso individual é o lócus do contato, ou seja, que se processa na mente humana. A prática do uso alternado de duas línguas é conhecida como bilinguismo, e a pessoa envolvida, bilíngue. Nesse sentido, o autor apenas menciona o bilinguismo individual.

Para Couto (2009), existe o bilinguismo individual como fenômeno idioletal e o bilinguismo social como fenômeno societário. No primeiro caso, o bilinguismo é mental e é quando, por exemplo, alguém aprende uma língua estrangeira. No segundo caso, o bilinguismo é compartilhado com outros membros da comunidade, ou seja, duas línguas convivem em um mesmo espaço-tempo de um grupo de pessoas. 
O contato linguístico é considerado por alguns antropólogos como mais um aspecto do contato cultural, e a interferência linguística como uma faceta da difusão cultural e aculturação (WEINREICH, 1953, p. 5). De fato, fatores sociais, psicológicos e culturais são muito importantes para complementar a explicação sobre o contexto do bilinguismo individual, como (p. 3 e 4):

- a facilidade verbal do falante em geral e sua habilidade de manter as duas línguas separadas;

- relativa proficiência nas duas línguas;

- especialização no uso de cada língua por tópicos e interlocutores;

- maneira de aprender cada língua;

- atitudes com relação a cada língua: estereótipos;

- tamanho do grupo e sua homogeneidade ou diferenciação sociocultural; partilha em subgrupos que usam uma ou outra língua como sua língua materna, fatores demográficos, relações sociais e políticas entre esses subgrupos;

- atitudes estereotipadas com relação a cada língua (prestígio), status indígena ou imigrante para as línguas;

- atitudes com relação à cultura de cada comunidade;

- atitudes com relação ao bilinguismo em si;

- tolerância ou intolerância com relação à mistura de línguas e para falas incorretas;

- relação entre o grupo bilíngue e as comunidades de cada língua separada.

O estudo de Weinreich remonta à década de 50, antes mesmo de a Sociolinguística existir. Por isso, talvez, alguns dos termos que o autor utiliza seriam considerados pejorativos e inaceitáveis atualmente, tais como "status indígena" e "falas incorretas". É importante registrar também que, nos estudos de contato de línguas, essa visão de Weinreich sobre a separação rígida das línguas por tópicos ou interlocutores é ultrapassada, uma vez que não é possível delimitar radicalmente as línguas, muito menos os tópicos ou interlocutores.

De qualquer forma, os fatores acima listados podem influenciar no grau de bilinguismo dos falantes, bem como a proximidade, a aceitação e o uso das línguas. 
Weinreich (1953, p. 11) também diferencia a interferência na fala e na língua. Para o autor, por exemplo, na fala, ocorre uma renovação de pronúncias do falante bilíngue como resultado do seu conhecimento pessoal da outra língua. Na língua, encontramos o fenômeno da interferência que, ocorrendo frequentemente na fala dos bilíngues, se torna "habitual" e "estabelecida". Seu uso não é mais dependente do bilinguismo.

Numa tentativa de associar essa pesquisa à teoria de Weinreich, entendemos que a interferência na fala seja bem específica, ou seja, própria do indivíduo, idioletal e, de certa forma, aleatória. No fenômeno de primeira pessoa do plural, nosotros não é recorrente nem sistemático quando os uruguaios estão falando português, mas aparece, principalmente, na fala dos que têm pouco domínio do português. Posto isso, esses dados seriam correspondentes à interferência na fala, e não à variação linguística, diferentemente da variação já implementada entre nós e a gente.

Por outro lado, o critério para delimitação da interferência e da variação seria a própria quantificação dos dados, que nos mostraria se o fenômeno é aleatório ou não. No caso do português uruguaio, a interferência na língua seria semelhante à utilização variável de nós e a gente pelos colaboradores uruguaios e brasileiros, ou seja, seria o caso típico da variação linguística, recorrente e sistemática. Não usamos o termo interferência como sinônimo de variação linguística, mas apenas tentamos estabelecer um diálogo entre a teoria da variação e mudança linguística e o trabalho de Weinreich (1953), desenvolvido antes do surgimento da Sociolinguística.

Outro precursor dos estudos de contato linguístico é Pedro Rona, com sua obra El Dialecto 'Fonteirizo'del Norte del Uruguay, de 1965, na qual inicia a discussão sobre o contato linguístico na fronteira Brasil-Uruguai, local cuja população de descendentes de colonos brasileiros tem preservado o português. Para ele, os fronteiriços (diversas variedades do dialeto fronterizo misto) se constituíam fortemente de formas lusitanas do espanhol e de formas hispanizadas do português, podendo existir outros fronteiriços igualmente comparáveis com os descobertos no Uruguai.

Rona (1963, p. 5) afirma que, quando começou a estudar o espanhol do Uruguai, não esperava encontrar um dialeto português. Depois da descoberta, o autor passa a estudar o sistema fônico do fronterizo. Uma passagem interessante em Rona (1963, p. 8) é 
cuando estudiamos los orígenes de los actuales dialectos fronterizos, debe tenerse en cuenta que no se trata de una influencia del portugués sobre el castellano (ya que no había aquí población hispánica antes de la llegada y establecimiento de los brasileños), sino, al revés, de la influencia de castellano sobre una base portuguesa.

É difícil, todavia, saber qual a direção da interferência e, consequentemente, em qualquer nível linguístico, ou seja, se é interferência do português no espanhol ou interferência do espanhol no português, mesmo porque as influências são mútuas seja do espanhol no português, seja do português no espanhol. O fato é que, na região de Aceguá, se fala predominantemente o português, tanto do lado brasileiro quanto do lado uruguaio.

Ainda segundo Rona, a expresão "dialectos fronterizos" aparece no plural, porque o autor descreve a existência de três tipos de mistura linguística: (i) convivência de hispano-falantes com luso-falantes; (ii) grande maioria de indivíduos bilíngues; (iii) dialeto misto (RONA, 1963, p. 12).

A partir dessa análise, quatro variedades subdialetais são definidas de acordo com os seguintes fatores: (i) a proporção de modos castelhanos (inexistentes em português) e portugueses (inexistentes em castelhano) na morfologia verbal; (ii) a proporção de palavras castelhanas e portuguesas no léxico; (iii) o sistema fonológico (limitado aos fonemas segmentais); e (iv) o caráter de "voseante" ou "tuteante 21 ", (RONA, 1963, p. 13). Assim, as variedades linguísticas a que Rona se refere são:

- Variedade artiguense: departamento de Artigas e Salto. Fronterizo castelhano. Característica voseante.

- Variedade tacuaremboense - departamento de Rivera e Tacuarembó. Poucas palavras castelhanas e morfologia quase totalmente portuguesa. Característica tuteante ${ }^{22}$.

- Variedade melense - departamento de Cerro Largo em sua parte ocidental com Melo. Palavras e morfologia espanhola e traços fônicos mais portugueses. Caracaterística voseante.

\footnotetext{
21 "Voseante" é quando a região utiliza predominante ou exclusivamente "vos", e "tuteante" é quando a região utiliza predominante ou exclusivamente "tu", ambos como pronome de segunda pessoa do singular.

${ }_{22}$ Carvalho (2010, p. 7), no entanto, demonstra quantitativamente que em Rivera a característica não é predominantemente tuteante $(23 \%)$, mas sim voseante $(76 \%)$.
} 
- Variedade yaguaronense - escassos vocábulos castelhanos, mas modos morfológicos castelhanos abundantes. Traços fônicos do português. Característica voseante.

No caso da variedade melense, apesar de Aceguá fazer parte de Cerro Largo e estar a 60km de Melo, Rona não a menciona. Não podemos incluí-la nessa discussão, porque a realidade linguística de Aceguá é totalmente diferente da de Melo. Enquanto em Aceguá o uso do português predomina, inclusive no lado uruguaio, em Melo se fala apenas o espanhol.

Rona (1963, p. 18) propõe três análises sobre a mistura nos sistemas fônicos. Na convivência de hispano-hablantes monolíngues e luso-brasileiros monolíngues, não há interação no sistema fônico porque eles se entendem bem e, portanto, não há necessidade de acomodação linguística. Um bilíngue que fala um castelhano genuíno, mas um português espanholado possui dois sistemas linguísticos. Já o falante do dialeto fronteiriço, monolíngue em fronteiriço, somente tem um sistema composto de algumas características do português e outras do castelhano. Essa diferença também é utilizada por Elizaincín (1992) e Hensey (1969, 1972), mas contestada por Carvalho (2003), que propõe, em vez disso, um continuum que vai desde o português até o espanhol ou viceversa.

No caso de Aceguá, poderíamos associar o duplo sistema linguístico aos bilíngues da fronteira, que falam português e espanhol. O sistema linguístico único seria o caso do "portunhol”, falado apenas por monolíngues em situações específicas de contato como, por exemplo, no comércio e em outros domínios que necessitam, uma vez que não têm escolha. Assim, o que Rona chama de português espanholado denominamos português uruguaio, que se trata de uma variedade do português com interferências do espanhol em diversos níveis linguísticos.

Para Rona (1963), no sistema próprio do fronteiriço, o último grau de mistura é a coexistência parcial de línguas dentro do mesmo indivíduo. Cria-se, pois, um sistema completamente novo (fronteiriço), que tem características do português e do espanhol (p. 27). No fronteiriço português, existem comparações, distinções e traços provenientes da mistura. "La etapa de conversión automática, que es la primera etapa de la mezcla, puede transformar todas las $[\beta]$ castellanas en $[b]$, o todas las $[b]$ portuguesas en $[\beta]$ " (RONA, 1963, p. 28). Ainda segundo o autor, 
las consecuencias de la mezcla sobre el sistema originan exclusivamente una reducción de las oposiciones, mientras que no se crea ninguna oposición adicional, inexistente en castellano o portugués. Esto significa que, desde el punto de vista fonémico también, la mezcla idiomática se resuelve en un empobrecimiento del caudal de elementos funcionales de la lengua (RONA, 1963, p.38)

Para Rona, a redução de oposição se deve ao fato de o sistema consonântico e vocálico do "português fronteiriço" ser igual ao português, o que, mais uma vez, corrobora o status hoje de português uruguaio. É por essas e outras semelhanças que consideramos o português falado no Uruguai como uma variedade da língua portuguesa.

Posto isso, percebe-se que, do ponto de vista da variação pronominal de primeira pessoa do plural, o português uruguaio de Aceguá não pode ser explicado como mistura linguística, pois, ao invés de reduzir a oposição de a gente indefinido (português arcaico e espanhol) e pronominalizado (português brasileiro) ao uso de nós, que tem a mesma correspondência formal nas duas línguas (nostrosos e nós), a comunidade faz o contrário, ou seja, mantém e propaga o uso de a gente como primeira pessoa do plural, inexistente no espanhol, mas presente no português. Nesse sentido, a variação linguística se propaga de forma linguística e social, corroborando sua sistematização.

Nesse sentido, não há simplificação, muito menos "empobrecimento", mas sim acréscimo de um pronome em co-ocorrência com o nós. Insere-se um novo elemento e, então, estabelece-se a variação linguística entre duas formas para uma só entidade gramatical.

Ainda que haja possíveis reduções de oposição nas línguas em contato, isso não significa um "empobrecimento" funcional da língua do ponto de vista da variação linguística. No entanto, nesse caso, nossa análise não se encaixa totalmente no princípio da convergência linguística (POPLACK, 1993, p. 256), nem na afirmação de Labov (2008, p. 345), epígrafe deste capítulo, já que o fenômeno linguístico da alternância nós e a gente mostra que as fusões não se expandem em detrimento das distinções, uma vez que a expressão a gente se manifesta diferentemente nos dois sistemas linguísticos (espanhol e português).

Esse uso também não é idiossincrático, mas sim variável. Portanto, não há convergência linguística para a variante comum nas duas línguas (nós e nosotros no português e no espanhol, respectivamente), uma vez que é a variante a gente do português que também faz parte do quadro pronominal do português uruguaio. A gente, na verdade, é cognato de la gente, e, portanto, essa semelhança deveria impedir (ou 
problematizar) a entrada do a gente gramaticalizado no português uruguaio, o que de fato não acontece, ou seja, o pronome inovador a gente como primeira pessoa do plural se expande cada vez mais no português brasileiro e avança, inclusive, as fronteiras políticas entre Brasil e Uruguai.

Dando continuidade à história dos estudos sobre contato linguístico na fronteira, a partir do trabalho de Rona (1963), surgem outros trabalhos importantes na área do contato entre português e espanhol na região da fronteira entre Brasil e Uruguai.

Hensey, em 1972, publica The Sociolinguistics of the brazilian-uruguayan border sobre a situação sociolinguística da fronteira Livramento (Brasil) e Rivera (Uruguai). Inicialmente, o autor (1972, p. 13) descreve as diferenças entre a região fronteiriça do Brasil e do Uruguai em termos de desenvolvimento social e econômico. Essa descrição da década de 70 é totalmente atual, porque a realidade local ainda mantém certas diferenças. Em pleno início do século XXI, a região fronteiriça brasileira continua sendo vista como mais desenvolvida economicamente e mais populosa, especialmente na área de contato imediato até o norte do Uruguai.

Hensey (1972, p. 76) relembra que a influência linguística em ambas as direções foi consequência da coexistência de populações falantes de espanhol e português na Cisplatina. Por razões históricas, os brasileiros predominaram no Rio Grande do Sul e em algumas áreas do norte do Uruguai. Assim, o português foi preservado nessa região, inclusive no ambiente familiar, enquanto o espanhol se restringiu à língua oficial e à língua de instrução. Por isso, é muito mais comum ver uruguaios bilíngues do que brasileiros bilíngues, como no caso de Aceguá.

Sobre os resultados do contato linguístico, Hensey (1972, p. 71-75) descreve alguns exemplos sintáticos como:

a redução no paradigma verbal do português popular não ocorre no espanhol da fronteira (eu canto, tu/você canta, ele canta, nós/a gente canta, vocês canta, eles canta $)^{23}$;

(ii) a concordância de gênero e de número, em ambas as línguas, afeta os determinantes, adjetivos e substantivos, mas no português popular é marcada apenas no primeiro elemento à esquerda do sintagma, diferentemente do espanhol do Uruguai;

\footnotetext{
${ }^{23}$ Exemplos meus, mas é claro que as pessoas usam a concordância padrão e não padrão de forma variável no português brasileiro.
} 
(iii) o português permite que o pronome átono venha antes do infinitivo (Você quer me encontrar?), diferentemente do espanhol que só aceita ênclise com o infinitivo (Quieres encontrarme) ${ }^{24}$;

(iv) o tempo verbal é semelhante em ambas as línguas, exceto o infinitivo flexionado do português, e o futuro do subjuntivo com as conjunções que e quando, já que no espanhol se usaria o presente do indicativo ou presente do subjuntivo (se fôr = si voy, quando chegarmos $=$ cuando lleguemos) $)^{25}$

Sobre a redução do paradigma verbal no espanhol da fronteira, é preciso verificar, com estudos variacionistas, se essa variação existe ou não.

A referência à concordância de gênero e de número merece esclarecimentos consistentes com base em pesquisas variacionistas já realizadas a respeito do português brasileiro. Sobre a concordância de número, há o trabalho sólido, entre outros, de Scherre (1988), e, sobre a concordância de gênero, há estudos como os de Lucchesi (2000), Dettoni (2003) e Pacheco (2010). As análises sobre o gênero mostram que há encaixamento linguístico entre ambas as concordâncias, favorecidas nos elementos à esquerda do sintagma, o que não quer dizer que sejam marcadas "apenas" no primeiro elemento. Além disso, Carvalho (2006) mostra que os padrões de concordância de número entre elementos do sintagma nominal são muito parecidos no português brasileiro e no espanhol da fronteira Brasil-Uruguai.

$\mathrm{Na}$ explicação do subjuntivo, há uma ponderação extremamente interessante sobre o que se considera interferência. Se um bilíngue, falante de espanhol como primeira língua, alterna o futuro do subjuntivo do português com o presente do indicativo ou presente do subjuntivo (se vou, quando chegue), isso sugere interferência. Para Hensey (1972, p. 73), parece difícil demonstrar interferência gramatical espanhola no português, embora o inverso seja mais fácil. O único caso que parece de fato ser interferência gramatical é o exemplo "tudo o que eu diga", no lugar de "tudo o que eu disser", ou seja, futuro do subjuntivo alternando com o presente do subjuntivo, como influência do espanhol, que seria "todo lo que (yo) diga". No entanto, sabemos que esse último exemplo é variável no Brasil e ocorre em diversas variedades do português

\footnotetext{
${ }^{24}$ Exemplos meus.

${ }^{25}$ Parece que Hensey se refere ao português e espanhol padrão, porque no português falado também há variação.
} 
brasileiro, inclusive do Sul, no Paraná (FAGUNDES, 2007). Assim, para nós, as diferenças e semelhanças, ainda nesses exemplos, não são tão facilmente definíveis em ambas as línguas.

Nesse sentido, percebe-se que os estudos precursores sobre contato de línguas baseavam-se em informações do português padrão ou de fontes não descritivas do português falado no Brasil. Atualmente, é possível entender melhor a realidade linguística do português uruguaio frente às pesquisas variacionistas que têm sido realizadas, especialmente depois do trabalho desenvolvido por Carvalho (2003).

Na década de 70, Hensey (1972, p. 78-79) afirmava que o espanhol está ganhando terreno entre as famílias mais pobres e, por isso, no futuro, as duas línguas devem coexistir de maneira menos desigual. Entretanto, segundo o autor, nos anos 2000, o português continua predominando entre a maioria dos uruguaios da fronteira. Para o autor, como a língua de casa não é aceita no meio oficial e na educação, ela tende a ser considerada língua mista ou jargão fronteiriço. Carvalho $(2003,2006)$ também discute que a percepção do português uruguaio como um sistema híbrido é mais social que linguística.

Elizaincín, Behares e Barrios, em 1987, publicam Nós falemo brasilero: Dialectos Portugueses en Uruguay, sobre a descrição linguística na zona fronteiriça dos Dialectos Portugueses do Uruguai (DPUs). A análise feita diz respeito aos níveis da morfologia e sintaxe, uma vez que, segundo os autores, Hensey e Rona já haviam se preocupado com o nível fônico.

Segundo Elizaincín, Behares e Barrios (1987, p. 13), a nomenclatura de DPU diz respeito aos modos de falar (dialetos) da fronteira que têm como consequência a variabilidade interna e a base lusitana, ou seja, a base dos DPUs é a língua portuguesa. A hipótese dos autores é que esses dialetos de base portuguesa são mistos e evidenciam forte influência do espanhol. Novamente a ideia de que as línguas em contato são mistas e muito variadas permeia o discurso dos autores supracitados. Segundo eles, a variabilidade é tão grande que justifica o método que propuseram para quantificar ambas as línguas por meio de um só continuum.

Em Dialectos en contacto, de 1992, Adolfo Elizaincín faz uma revisão dos resultados e discussões do livro Nós falemo brasilero. A abordagem do estudo, de acordo com o autor, é centrada em um modelo ampliado da dialetologia (ELIZAINCÍN, 1992, p.17), pois abarca várias dimensões da variação, além da diatópica. Nesse sentido, a variação é vista como ordenada, e não ao acaso ou aleatória, a partir de uma 
regularidade segundo os níveis socioculturais ou extralinguísticos como idade, origem geográfica, sexo etc.

Como ambos os livros são parecidos, optamos por resenhar as duas obras de forma complementar, ou seja, selecionamos passagens importantes e inovadoras de cada uma, mesmo porque os fenômenos linguísticos, por exemplo, são descritos com pouca ou nenhuma alteração nas duas obras.

No livro de 1992, Elizaincín (1992, p. 65) relembra os pressupostos teóricos da Variação Linguística, propostos por Labov e mostra que os estudos da época eram concentrados no nível fônico. O problema se daria em nível morfológico ou sintático, porque possivelmente haveria mudança de significado, sem relação com fatores extralinguísticos. Segundo Elizaincín (1992, p. 66),

nuestro tema no es la variación en el campo de una lengua estándar, sino la variación resultante de las situaciones de contacto. Para tratar de diferenciar ambos conceptos hemos propuesto llamar a esta última variabilidad.

Elizaincín (1992, p. 117 e 217) associa alta variabilidade à mistura, instabilidade e insegurança extrema do falante. $\mathrm{O}$ autor afirma que a natureza dos dialetos é mista, porque a variabilidade é inerente a esse falar local, como se a variabilidade não fosse inerente a qualquer fala, independentemente de ser da fronteira.

Elizaincín, Behares e Barrios (1987, p. 16) propõem a diferença crucial entre variação e variabilidade linguística. A variação está para a instabilidade das línguas standard assim como a variabilidade está para a instabilidade dos dialetos bilíngues, pois nesse caso essa variabilidade é consequência do contato de duas ou mais línguas.

Para o autor, a "variação" é resultante do que ocorre no campo de uma língua standard e a "variabilidade" é consequência de situações de contato. Essa dicotomia só confirma ainda mais a distinção desnecessária que se fazia entre a variação linguística de dialetos monolíngues e bilíngues. O fato é que ambos variam e mudam segundo padrões sociais e linguísticos determinados.

Mesmo assim, em diversas passagens do livro, Elizaincín mistura indiferentemente norma padrão e variedade linguística ou atribui a influência espanhola às formas tipicamente brasileiras, o que compromete, em parte, seus resultados. Alguns exemplos são as preposições "con" e "co" (com) e "pa" (para) (ELIZAINCÍN, 1992, p. 108 e 112), em que o autor afirma ser de origem espanhola, sem levar em conta as variedades do português brasileiro que as utilizam. A alternância para/pra/pa ocorre no 
Brasil de forma generalizada e, na fala, quase não utilizamos mais a variante "para", como atesta o trabalho de Felgueiras (1993) sobre a fala carioca.

A metodologia do trabalho proposta por Elizaincín (1987 e 1992), assim como Espiga (2008), está centrada em um continuum ${ }^{26}$ que se distribui desde o polo português até o polo espanhol. O método da pesquisa constitui-se de várias etapas: (i) medida de variabilidade junto com a localização dos pontos geográficos estudados em determinado lugar da escala contínua; (ii) delimitação de zonas geográficas, segundo a maior ou menor afinidade com os polos português e espanhol da escala contínua (ELIZAINCÍN, 1992, p. 67). Assim, a variabilidade estaria relacionada à variação específica e resultante das situações de contato. Um exemplo seria a preposição, pois no português se diz falar para e no espanhol, decir a (ELIZAINCÍN, 1992, p. 107).

Essa variação típica do contato de línguas é o que o autor chama de variabilidade, em contrapartida a fenômenos que ocorrem nos dialetos monolíngues, como $t u$, você, $c \hat{e}$. Toda forma espanhola presente nos DPUs é considerada variabilidade, ou seja, esse conceito, para Elizaincín (1992), é mais abrangente e inclui qualquer interferência do espanhol no português. No entanto, no exemplo "decir a", analisaríamos como um caso de interferência, porque esse uso em espanhol aparece raríssimas vezes nas entrevistas coletadas em Aceguá. Portanto, não seria um fenômeno variável nessa fronteira.

Mas será que a "variabilidade" de Elizaincín no português uruguaio é sempre consequência do contato linguístico? Ou será que não pode ser consequência natural da própria configuração interna do português uruguaio?

Ainda segundo Elizaincín (1992, p. 67), a partir de entrevistas realizadas, escolhe-se o traço linguístico importante ou significativo e depois se calcula a percentagem dessas ocorrências segundo alguns fatores sociais, nem sempre muito definíveis. Observa-se, então, uma relação inversa entre a diferença percentual e a variabilidade, pois, quanto maior a diferença percentual em cada localidade entre as variantes alternantes, menor a variabilidade e vice-versa. Para o autor,

la misma diferencia porcentual, en último paso, permite situar las localidades encuestadas en la escala continua según las variantes alternantes. Así, por

\footnotetext{
${ }^{26}$ A noção de continuum foi introduzida na Sociolinguística brasileira por Bortoni-Ricardo (1985) em um trabalho sobre a urbanização dos falantes rurais. Assim, haveria três escalas de continuum: rural - urbano; oralidade - letramento; monitoração estilística. No caso dos trabalhos sobre a fronteira, Elizaincín (1987 e 1992) e Espiga (2008) fazem uma releitura do conceito de continuum para a escala entre as línguas: português - espanhol.
} 
ejemplo, si obtenemos dos pronunciaciones de -e ([e] o [i]), la primera será considerada española mientras que la segunda, portuguesa. Así, si la localidad x tiene $80 \%$ [-e] y $20 \%$ [-i], a saber, una diferencia porcentual de $60 \%[\ldots]$, es decir, <<tiende〉> hacia el polo español de la escala. (ELIZAINCÍN, 1992, p. 67-68)

([-i]) Port. 100 0 60 100 Esp. ([-e])

\section{Loc. $\mathbf{x}$}

Figura 1: Escala de Elizaincín (1992, p. 68) sobre o continuum entre o português e o espanhol.

O autor exemplifica sua metodologia baseada em uma medida percentual com a pronuncia de $-\mathrm{e}([\mathrm{e}]$ ou [i]), em que a primeira pronúncia seria considerada espanhola enquanto a segunda, portuguesa. Assim, se a localidade x tem $80 \%$ de [-e], variante associada ao espanhol, e $20 \%$ de [-i], variante associada ao português, a diferença seria de $60 \%$, o que significa que o fenômeno linguístico tenderia ao polo espanhol da escala (ELIZAINCÍN, 1992, p. 67). O problema é colocar a vogal -e final como característica do espanhol, já que as vogais finais são variáveis no Rio Grande do Sul e há muitas $-e$ finais no português gaúcho.

Outro exemplo semelhante é a afirmação de que a pronúncia da preposição "de" relaciona-se ao espanhol e a pronúncia “di” ao português (ELIZAINCÍN et alii,1987, p. 46), que também não pode ser validada, porque essa pronúncia é variável no português brasileiro, principalmente no Sul do país, assim como várias outras estruturas citadas no livro como espanholas, mas que têm equivalentes também no português brasileiro.

A metodologia do estudo é baseada em uma medida estatística. O ponto extremo ou limite de cada variante é o número 100 de cada lado. A diferença entre as duas percentagens significa o número real e a localização do polo português ou espanhol. Como a variante mais recorrente é de $80 \%$, ainda com a diminuição de $20 \%$, a maior parte, de $60 \%$, ainda permanece do lado do espanhol.

Se a diferença percentual for de $100 \%$, ou seja, $100 \%$ para uma variante, a variabilidade não existe, ou seja, é categórica. Se a diferença for de 0\%, ou seja, $50 \%$ para cada variante, a variabilidade é máxima, porque não estaria próxima nem do polo português tampouco do espanhol. Por isso, há uma relação inversa entre diferença percentual e variabilidade externa: a maior diferença porcentual será a menor variabilidade e vice-versa.

Já é perceptível, com apenas esse exemplo linguístico, que o autor não levou em consideração a variação linguística interna do próprio português, pois as pronúncias [e] 
e [i] não são categóricas, como pode ser constatado, por exemplo, em Bisol (2009). Considerando que o texto do autor é de 1992, pesquisas variacionistas já eram feitas há bastante tempo sobre o português brasileiro.

Assim, vários exemplos de Elizacinín são baseados em um português padrão, que é, em grande parte, diferente da fala real dos brasileiros. Dessa forma, é muito difícil delimitar com certeza as interferências do espanhol no português, justamente porque as línguas são parecidas. Por isso, é extremamente delicado atribuir essas duas variantes a duas línguas distintas, porque há a mesma variação no português gaúcho.

Após o resultado estatístico, o autor observa as localidades que mais variam (Artigas, Rivera, Tranqueras, Vichadero e Minas de Corrales, Río Branco, Aceguá e Isidoro Noblía) e inserem-nas em um continuum Português-Espanhol.

Sobre as características dos DPUs, Elizaincín (1992, p. 208) diz que: (i) o bilinguismo em DPU e espanhol é típico de alguns setores mais altos da população, restando o monolinguismo à classe menos favorecida; (ii) a zona da fronteira foi povoada por luso-falantes, por isso a base predominantemente portuguesa dos DPUs; (iii) estigmatização da fala local pela escola e segmentos economicamente poderosos; (iv) fala vernacular restrita ao nível doméstico e cotidiano. Por isso, foram escolhidos informantes com esse nível socioeconômico, ou seja, de classes menos favorecidas. Para o estudo dos DPUs, foram explicados e exemplificados os seguintes critérios (ELIZAINCÍN, 1992, p. 89-93):

(i) Número de informantes - as 139 entrevistas têm a duração de 20 a 30 minutos. Os informantes são representativos da comunidade e são compostos por homens e mulheres, de várias faixas etárias e de nível socioeconômico baixo.

(ii) Tipo de informante - a hipótese prévia é que os DPUs encontram-se nos níveis baixos da população, por isso foram selecionados informantes adultos, com pouca ou nenhuma escolaridade, e crianças com idade escolar que tinham "problemas de linguagem", detectados pelos professores, segundo Elizaincín.

(iii) Entrevistadores - o ideal é que o entrevistador seja da própria comunidade e minimamente sensível às questões linguísticas, porque a língua do entrevistador e os tópicos por ele escolhidos podem determinar o sucesso ou insucesso da entrevista. 
(iv) Entrevista - as entrevistas foram feitas geralmente nos lugares de trabalho, na casa do informante, na rua ou lugares públicos etc.

(v) Localidades - as entrevistas foram gravadas nas seguintes localidades: Artigas, Rivera, Tranqueras, Vichadero y Minas de Corrales, Río Branco e Aceguá e Isidoro Noblía.

(vi) Resultados linguísticos - a forma em questão deve aparecer mais de uma vez e em diferentes informantes para desconsiderar usos individuais (ELIZAINCÍN, 1992, p.103).

Elizaincín (1992, p. 97) já descrevia Aceguá como um pequeno povo do Departamento de Cerro Largo, na época com cerca de 1000 habitantes, situados na linha fronteiriça com o Brasil. Nessa localidade são típicos agrupamentos rurais, nos quais vivem os moradores que se ocupam das tarefas agrícolas das grandes estâncias. A prática do contrabando também é frequente.

Sobre o tipo de informante, é importante fazer uma reflexão a respeito da associação que Elizaincín faz entre DPUs e "níveis baixos da população". O português falado na fronteira entre Brasil e Uruguai é um fenômeno muito mais histórico e identitário do que estratificado socialmente. Se Elizaincín não inseriu informantes de outras classes sociais, em tese, não há como comprovar essa hipótese associativa.

Ainda no mesmo tópico, o autor não deixa claro se associou o DPU a problemas de linguagem, porque se, minimamente, houve essa intenção, podemos considerar que se trata de um grande equívoco, já que qualquer variedade linguística é legítima de um povo e de uma sociedade. Parece que esse "problema de linguagem" se refere às crianças falantes de português como L1 no Uruguai ou, segundo Elizaincín, faltantes dos DPUs. Na época, havia centros que ajudavam crianças com dislexia, por exemplo, e que incluíam essas crianças falantes de português. Essa prática sempre foi criticada por Elizaincín.

Sobre os resultados linguísticos, Elizaincín (1992) considera como fenômeno linguístico apenas as formas linguísticas que aparecem mais de uma vez e em diferentes informantes, o que descartaria possíveis usos individuais. No entanto, também é de suma importância, em nosso trabalho, entender o que os usos individuais significam, como veremos no capítulo 5 (p. 164) acerca da análise variacionista.

Nesse sentido, alguns fenômenos fonéticos são analisados por Elizaincín (1992, p. 101) como distintivos entre as línguas ibéricas. Como nos DPUs predomina a forma 
do português, Elizaincín usa esses exemplos para afirmar que os DPUs são de base portuguesa.

1. Lactem $>$ leche>leite

2. Filium $>$ hijo $>$ filho

3. Petram $>$ piedra $>$ pedra

4. Ovum>huevo>ovo

5. Speculum>espejo $>$ espelho

6. Jocare $>$ jugar $>\mathrm{j}[\mathrm{s}]$ ogar

Esses dados mostram que as palavras mais comuns nos DPUs seguem a forma fonético-fonológico das palavras em português, como a ditongação de "leite", a monotongação de "ovo" e "pedra" (comparado ao espanhol), a pronúncia e escrita de "lh" e a palatalização de "jogar".

Vários exemplos de outros níveis linguísticos, como morfológicos e sintáticos, também são descritos nos DPUs como se fossem únicos desse falar. Novamente, não se levou em consideração a língua falada brasileira e suas variedades linguísticas. Além disso, os fatores sociais também não são controlados separadamente para cada fenômeno linguístico, porque muitas vezes são agrupados. Entre os exemplos linguísticos que caracterizam os DPUs, Elizaincín et alii (1987) descrevem:

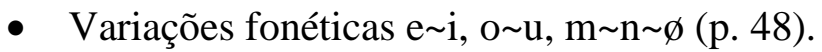

- Uso perifrástico de a filha dela ao invés da indicação de possessão em sua filha (p. 59).

- Preferência pelo modo indicativo, em detrimento do subjuntivo e imperativo (Ex: falta muito para que é ao invés de falta muito para que seja) (p. 63-64).

- Elisão do "-r" final de infinitivo (p. 72).

- Ausência do infinitivo pessoal ou conjugado (p. 73).

- Uso de "haver" no lugar de "ter" (Ex: há decaído/a mãe dela tinha mandado) (p.76).

- Ausência de clíticos (Ex: Ela quiría a boneca no lugar de Ella la queria a la muñeca) (p. 86). 
- Nenhum caso de que relativo precedido de preposição (Ex: a maestra qu'eu taba antis) (p.97).

- Eliminação de marcas redundantes de concordância (seis onibo, muitus animal, us dever) (p. 103-104).

- Simplificação dos paradigmas verbais (p. 74 e 105).

Como se pode notar, todos esses fenômenos variáveis são legítimos do português brasileiro, o que também aponta o fato de o português uruguaio ser uma variedade do português brasileiro, e não uma terceira língua ou língua mista.

Um dos próprios autores do livro de 1987, Behares (2010), faz uma autocrítica com relação ao trabalho de Elizaincín, Behares y Barrios (1987) e Elizaincín (1992) sobre as diversas soluções dadas aos problemas descritivos, as quais comprometeram os resultados finais. Ainda que esses estudos precursores sobre o português da fronteira tenham um enorme valor para a compreensão dos fenômenos linguísticos locais, Behares (2010) assinala os três principais problemas metodológicos:

(i) o corpus coletado por entrevistadores que não falavam DPU;

(ii) a herança linguística do português e do espanhol totalmente baseada nas gramáticas normativas de ambas, descuidando das variantes e dos processos dialetais, sobretudo no caso do português. Acreditava-se que havia construções autônomas dos DPUs, como produto do contato, quando na maioria dos casos eram formas normais do português coloquial de diversas regiões do Brasil;

(iii) a escolha pessoal dos falantes.

Assim, a segunda crítica de Behares (2010) relata bem o que exemplificamos anteriormente com os fenômenos linguísticos pouco inovadores encontrados também na fronteira e, consequentemente, no português falado pelos uruguaios no norte do Uruguai. Ou seja, os exemplos de Elizaincín et alii. (1987) sequer levavam em consideração as pesquisas variacionistas sobre o português brasileiro. A terceira crítica refere-se à inobservância da diferença entre escolha pessoal e aleatória do falante e variação linguística na comunidade como um todo.

Nas décadas de 60 a 90, os estudiosos pensavam ter encontrado outra língua ou outro dialeto na fronteira Brasil-Uruguai. Já na década de 2000, a descoberta é que esse 
falar fronteiriço é, em verdade, uma variedade do português brasileiro, principalmente depois dos estudos variacionistas de Carvalho (2003).

Ainda em relação aos DPUs, Elizaincín denominava as falas fronteiriças de instáveis por conta da variabilidade resultante do próprio contato linguístico. Segundo Elizaincín (1992, p. 71),

\begin{abstract}
es aun mucho más compleja la descripción de las lenguas resultantes del contacto, pues a la variación normal de la lengua histórica se suma la variabilidad propia de dichas situaciones conflictivas. Dicho con otras palabras, si se trata de describir B, resultante del contacto de A y C, en Ella se encontrará, teóricamente, rasgos de la variación de A, de C, más la suya propia (esto dependerá del grado de normalización alcanzado por B en el momento en que se la estudie).
\end{abstract}

No entanto, sabe-se que toda e qualquer língua varia e muda, independentemente de estar em contato direto com outra língua, mesmo porque, dentro de um mesmo sistema linguístico, certamente há ou houve contato indireto com outras línguas ou dialetos, apesar de ser menos perceptível.

Além disso, a língua falada na fronteira Brasil-Uruguai não é resultante do contato linguístico, mas sim do português que há séculos existe na região. Dentro da nossa concepção, não existem as línguas A, B e C, mas apenas as línguas A (espanhol) e B (português) com suas características específicas. Se considerarmos o português falado no Uruguai como uma variedade linguística do português, não é possível compartilhar da visão de Elizaincín (1992, p. 233) quando afirma que esses dialetos fronteiriços não podem ser considerados formas próprias da variação no marco de uma língua histórica.

\title{
2.2 Como definir o falar da fronteira?
}

Entretanto, a menos que os uruguaios adquiram o português
standard, a interferência do fronterizo poderia ser
institucionalizada como Português Uruguaio (Tradução nossa). (Hensey, 1972, p. 78) ${ }^{27}$

A partir da citação de Hensey (1972, p. 78) sobre a língua da fronteira, já é possível identificar um traço de que se tratava de uma variedade linguística do português, conforme evidencia Carvalho (2003). A própria terminologia "português

27 "However, unless Uruguayans acquire standard (i.e., Brazilian) Portuguese, interference of the fronterizo type may become institutionalized and yield a specifically Uruguayan Portuguese" (HENSEY, 1972, p. 78). 
uruguaio" já é mencionada por Hensey, mas apenas para o português falado pelos bilíngues, enquanto o fronterizo é reservado para os monolíngues.

Estudando o contato de línguas, percebemos a nomenclatura diversificada que cada autor atribui para o falar da fronteira Brasil-Uruguai. Para cada definição, obviamente, existem as crenças ideológicas, as posições linguísticas e as linhas teóricas assumidas pelos estudiosos. Por isso, com relação à denominação da variedade fronteiriça, é importante deixar claro o que faz parte do senso comum e o que de fato é comprovado e estudado pela Linguística. Como o objeto deste estudo é bastante complexo e singular, descrevemos nesta seção algumas características e classificações dadas pelos estudiosos da área.

Para classificar a situação do contato entre o português e o espanhol na fronteira Brasil-Uruguai, os principais termos ou expressões são listados abaixo:

Dialeto misto, fronterizo (RONA, 1963; HENSEY, 1972).

$>$ Interlecto (HENSEY, 1969)

$>$ DPU (Dialectos portugueses del Uruguay) e pré-pidgin (ELIZAINCÍN, BEHARES e BARRIOS, 1987).

Portunhol (MOTA, 2012; STURZA, 2005; FAULSTICH, 1997).

> PU (Português uruguaio) (CARVALHO, 2003).

Essas nomeclaturas serão detalhadas adiante, especialmente para que se tenha uma visão de conjunto de como o português da fronteira foi sendo classificado ao longo dos anos, desde sua descoberta pelos linguistas.

\subsubsection{Dialeto misto, fronterizo e pidgin}

Na década de 60, Rona (1963, p. 5) confirma a existência do dialecto mixto que denomina fronterizo, ou seja, um dialeto de base portuguesa que misturava o português falado na parte meridional do Rio Grande do Sul e o espanhol falado no Uruguai.

Posteriormente, Rona (1963) propõe dois dialetos fronterizos diferentes: o de base portuguesa e o de base espanhola. Segundo Behares (2010), foi graças a Rona que Celso Cunha, em 1979, incluiu em sua gramática o Dialeto Fronteiriço entre as variedades do português faladas no mundo. Sobre a constituição linguística dos fronterizos, Rona (1963, p. 7) afirma que 
consiste éste en una mezcla de portugués y español, pero que no es ni portugués ni español y resulta con frecuencia ininteligible tanto para los brasileños como para los uruguayos. Esto es, que en la cadena hablada hay trozos enteros que resultan incomprensibles para los luso-hablantes e hispano-hablantes que no conocen el "fronterizo".

Pela explicação de Rona (1963, p. 7), esse falar fronteiriço poderia ser equiparado a um pidgin, pois seria um sistema de emergência surgido da necessidade de comunicação entre pessoas adultas de diferentes línguas e culturas, sem sistematização, altamente variável e simplificado em relação às línguas que lhe deram origem.

Segundo Couto (1996), a forma pidginizada pode levar à crioulização, como ocorreu com o francês no Haiti e na Ilha Maurício e com o português na Guiné-Bissau, entre outras situações. A principal hipótese da crioulização é de que o crioulo é um pidgin, nascido a partir do contato entre povos que não conhecem a língua do outro, que se tornou língua materna (nativização). A outra é de que haverá o crioulo se o pidgin passa a ser língua principal de uma comunidade (comunitarização). Para Couto (1993, p. 91-92), só podemos afirmar que há um crioulo quando este é um pidgin nativizado, isto é, estabilizado em uma comunidade.

Segundo Philip Baker (apud Couto, 1996), o crioulo surge da necessidade de comunicação, portanto através de uma evolução lenta e gradual, e não de uma aprendizagem imperfeita da língua do povo dominante. Essa teoria é chamada de “criativista". Portanto, os crioulos têm diferença social por conta de sua formação sóciohistórica específica, mas do ponto de vista linguístico é uma língua, dialeto ou falar como qualquer outro (COUTO, 1996, p. 17).

Para Couto (1996), os crioulos são, com efeito, línguas mistas, constituídas de léxico das línguas europeias - superestrato - e de gramática das línguas africanas ${ }^{28}$ substrato. Ainda segundo Couto (2002, p. 227), o processo de formação das línguas crioulas e pidgins não pode ser considerado inteiramente como aleatório e caótico, visto que a hipótese da relexificação "prevê que os formadores dessas línguas, em situação de multilinguismo, pegam o significante (ou parte dele) da língua dominante e o associam a significados e possibilidade combinatórias de suas próprias línguas”.

No entanto, pela pesquisa de campo em Aceguá, é perceptível que o falar fronteiriço não é ininteligível, nem é tão indefinido que não se possa claramente notar

\footnotetext{
${ }^{28}$ Sabe-se que os crioulos não são formados apenas a partir da língua africana, mas também da língua chinesa como o crioulo macaense.
} 
que se trata de uma variedade do português. Para os falantes da fronteira, talvez, a distinção não esteja tão clara entre o português que eles realmente falam e outros tipos de denominações que não refletem bem a realidade, por conta da insegurança linguística e da estigmatização do falar local, mas, quando se conversa com eles, nota-se que há um bilinguismo pleno e que o português uruguaio tem grande proximidade com outras variedades do português brasileiro.

Dessa forma, os indivíduos sempre se comunicaram e se entenderam bem na fronteira e pertencem à mesma comunidade de fala (baseada na concepção de Labov (1972a) e Scherre (2006)), ainda que dividida politicamente ao meio, pois compartilham normas linguísticas (em grande parte no caso do português) e sociais. Posto isso, a língua em comum dos dois lados da fronteira é o português, falado como língua materna por ambos os povos. A nosso ver, nunca houve uma terceira língua na região e não há indícios também de que houve na fronteira alguma espécie de pidgin ou crioulo como cogitou Rona (1963). As evidências são a existência histórica do português na região, o bilinguismo dos uruguaios, a convivência pacífica dos povos e das línguas etc.

\subsubsection{Interlecto}

Hensey (1969) associou o português da fronteira às denominações interlíngua e interlecto. Nesse mesmo ano, Selinker (1969) também aborda sobre interlíngua, mas relacionada à aquisição de segunda língua, e não ao bilinguismo social do contato de línguas. Com isso, o autor traz o conceito de transferência linguística para o âmbito da interlíngua no sentido de que a língua materna é uma fonte linguística para o desenvolvimento da interlíngua durante o processo de aquisição de uma segunda língua, mas não só em matéria de interferência negativa, como também de transferência positiva por representar um sistema seguro que o aprendiz possui como base para elaborar hipóteses acerca do funcionamento da língua-alvo. Assim, Selinker (1969) desmistifica a ideia de que a língua materna é apenas fonte de erros na aquisição de uma L2, e, por isso, o termo interferência linguística cede lugar para a transferência negativa ou positiva.

Nesse mesmo sentido, o Diccionario de linguística aplicada y enseñanza de lenguas (RICHARDS, PLATT Y PLATT, 1997, p. 419) estabelece que transferência linguística é o efeito de uma língua na aprendizagem de outra. Esclarece que poderia haver transferência negativa, que é o uso de uma construção ou regra de uma língua 
materna que conduz a um erro ou forma inapropriada na língua-alvo. A transferência positiva é a que facilita a aprendizagem.

O conceito de interferência/transferência está vinculado à versão forte da análise contrastiva $(\mathrm{AC})$, segundo a qual a língua materna seria a primeira e única causa das dificuldades de aprendizagem de uma língua estrangeira e dos erros produzidos pelos aprendizes nesse processo. Daí a convicção de que todos os erros podiam ser prognosticados, identificando as diferenças entre a língua materna e a língua objeto de aprendizagem. Todavia, as pesquisas empíricas mostraram que a interferência da língua materna não explica a maioria dos erros dos aprendizes.

Para essa discussão, é pertinente salientar a observação de Fernandez (1997, p. 16) contra a equação contrastiva de que quanto "maior diferença entre as línguas, maior dificuldade e, portanto, maior número de erros por interferência”. É importante lembrar que o conceito de diferença é linguísitico e o de dificuldade é cognitivo. Assim, essa autora aponta que a sua pesquisa "mostrou reiteradamente que a interferência se verifica preferentemente quando os paradigmas da língua-alvo permitem uma estrutura semelhante à da LM [...]" (p. 16). Em outras palavras, a interferência acontece mais frequentemente entre aquelas línguas e estruturas linguísticas percebidas pelo aprendiz como sendo mais próximas, e não o contrário. Seria o caso do par espanhol/português brasileiro.

De forma geral, a caracterização de uma língua materna como tal só se dá se combinarmos vários fatores e todos eles forem levados em consideração: a língua da mãe, a língua do pai, a língua dos outros familiares, a língua da comunidade, a primeira língua adquirida, a língua com a qual se estabelece uma relação afetiva, a língua do dia a dia, a língua predominante na sociedade, a língua de melhor status para o indivíduo, a língua que ele tem mais fluência, a língua com a qual ele se sente mais à vontade. Todos esses aspectos são decisivos para definir uma L1 como tal (SPINASSÉ, 2006, p.5).

A aquisição de uma primeira língua ou da língua materna faz parte da formação do cidadão, pois à competência linguística se somam valores subjetivos e sociais, tais como a língua materna, a origem do falante e o uso diário.

De acordo com o Diccionario de linguística aplicada y enseñanza de lenguas (RICHARDS, PLATT \& PLATT, 1997), língua estrangeira é a língua não nativa de um país que é estudada para a comunicação com estrangeiros ou para a leitura nessa língua. Os autores fazem uma distinção entre língua estrangeira e segunda língua no sentido de que a primeira "é ensinada na escola, mas não é usada como língua veicular ou como 
língua de comunicação no país [...]” [enquanto a segunda] "é uma língua nativa num país que é aprendida nele por pessoas que têm outra primeira língua" (1997, p. 241). Eles definem primeira língua como sendo "a língua materna de uma pessoa, a primeira que se adquire [...] (1997, p. 330). Para Leffa (1998, p. 212):

\begin{abstract}
Uma distinção que também precisa ser feita refere-se aos termos segunda língua e língua estrangeira. Temos o estudo de uma segunda língua no caso em que a língua estudada é usada fora da sala de aula da comunidade em que vive o aluno (exemplo: situação do aluno brasileiro que foi estudar francês na França). Temos língua estrangeira quando a comunidade não usa a língua estudada na sala de aula (exemplo: situação do aluno que estuda inglês no Brasil). Para os dois casos usa-se aqui, como termo abrangente, a sigla L2.
\end{abstract}

Com relação à língua estrangeira, o conceito de interlíngua coloca o aprendiz como construtor de seu próprio sistema gramatical e postula que seu progresso se dá através de diferentes estratégias, algumas baseadas em sua L1, umas no seu desejo de comunicar-se e outras que podem apoiar-se na Gramática Universal.

A estrutura psicológica latente é um termo para descrever uma estrutura que permaneceria disponível no cérebro do indivíduo para desenvolver a L2, ou seja, seria um dispositivo biológico, parecido com a gramática universal de Chomsky, que ficaria ali apenas para a aquisição de língua estrangeira ou de uma gramática particular. Segundo Selinker (1972, apud Liceras, 1992, p. 79), apenas 5\% dos adultos chegam a dominar uma L2 como um nativo. A grande maioria jamais chegará a esse estágio, ou seja, percorrerá o continuum da interlíngua e apenas esses $95 \%$ ativam a estrutura psicológica latente.

Para Selinker (1972, p. 86), o aprendiz constrói sua interlíngua por meio de cinco processos psicológicos principais e inconscientes:

i. A transferência linguística - resultado de transferências da língua materna;

ii. A transferência de instrução - resultado de processos de instrução tais como: metodologia, material didático, quantidade e qualidade das amostras de língua-alvo etc;

iii. As estratégias de aprendizagem da língua alvo - resultado da relação entre aluno e materiais didáticos;

iv. As estratégias de comunicação na língua alvo - presentes nas tentativas do aluno para comunicar-se com nativos; 
v. A generalização das regras da língua alvo - produto de hipergeneralizações das regras e traços semânticos do material linguístico da língua alvo, ou seja, aplicação de regras em contextos que um falante nativo não as usaria.

Nesse sentido, "uma situación interlinguística se define como uma combinación específica de LM, LO e IL ${ }^{29 "}$ (SELINKER, 1972, p. 99), o que não significa que devamos conceber a interlíngua como uma mistura aleatória dos sistemas em contato. Assim, as identificações interlinguísticas que unem psicologicamente os três sistemas se ativam em uma estrutura psicológica latente quando o indivíduo produz orações da língua alvo (SELINKER, 1972, p. 90).

Nessa perspectiva, o portunhol não deveria ser considerado como interlíngua ou sistema transacional (SELINKER, 1972), mesmo se tratando de um fenômeno linguístico individual. Portanto, o portunhol não é uma língua específica no sentido social da palavra, mesmo porque pode apresentar certas idiossincrasias para um dado falante e não apresentar para outro, ou seja, seria muito mais idioletal do que dialetal. A interlíngua já é sistêmica, com ordenação linguística e social, tem regras linguísticas próprias, ainda que mude constantemente, seja individual e específica de cada aprendiz também.

Uma das características da interlíngua é a construção de um sistema com regras morfológicas, sintáticas e fonéticas próprias, criada pelo aprendiz no processo de aquisição de uma língua estrangeira ou de uma segunda língua. Nemser (1971) denomina interlíngua como um sistema aproximado e o descreve como sistema linguístico desviante empregado pelo aluno que tenta usar a língua meta. Corder (1971) o chama de dialeto (isto é, sistema) idiossincrático ou transicional (dada a sua instabilidade) e esclarece que o dialeto pode ou não refletir o comportamento de um grupo social. Selinker (1972) deixa claro que se trata de um "sistema linguístico independente", regular, sistêmico e também instável presente nas produções (orais e escritas) dos alunos. O caráter sistêmico da interlíngua também é reconhecido e reforçado por Tarone (1983) no seu estudo sobre a variabilidade desse sistema.

Segundo Corder (1971), o aprendiz de L2 não começa a desenvolver sua interlíngua com sua L1, mas com uma versão altamente simplificada daquela, algo

\footnotetext{
${ }^{29}$ LM - Língua Materna; LO - Língua Objeto ou Alvo; IL - Interlíngua.
} 
como uma memória dos primeiros estágios de aprendizagem da L1. Este sistema básico daria ao aprendiz suas primeiras hipóteses (consideradas por alguns linguistas como as regras universais que estão nas bases de todas as línguas).

Assim, para Corder (1971, p. 63), o dialeto idiossincrático seria a interlíngua ou o dialeto transacional, que se refere a sistemas cujas gramáticas compartem regras com outras gramáticas, mas também tem suas regras próprias que não são de uma, nem de outra língua, mantendo certa regularidade e sistematicidade.

O termo interlíngua, portanto, insere-se melhor no âmbito da aquisição de segunda língua para explicar o período intermediário de aquisição de outro idioma como uma prática individual.

\subsubsection{Portunhol}

Muitas áreas de pesquisa como a antropologia social entendem ou aplicam o termo "portunhol" de maneira equivocada. No texto de Hartmann (2003, p. 291), o "portunhol" é visto como a linguagem das classes menos favorecidas ou do meio rural, enquanto o monolinguismo é visto como pertencente a classes mais favorecidas, de maior grau de instrução, como se pode observar na citação a seguir:

\footnotetext{
Ao contrário de Dona Araceli, no entanto, que passou a vida em Moirones, localidade bastante próxima da fronteira com o Brasil, Tomazito morou durante vários anos na capital do país, onde completou seus estudos, daí a diferença nas formas de expressão dos dois: D. Araceli utiliza o "portunhol" (onde novamente a metáfora "entreverado" aparece, referindo a mistura de idiomas), enquanto Tomazito privilegia o espanhol. Percebe-se com esses dois exemplos que as diferentes regras de fala utilizadas podem ser relativas à origem social do narrador (Tomazito é estancieiro, D. Araceli é lavadeira) mas sobretudo ao grau de instrução e à moradia no campo ou na cidade (a frequência de uso e de aceitação do "portunhol" é muito maior no meio rural). (HARTMANN, 2003, p.291).
}

Percebe-se, portanto, que o diálogo da Sociolinguística com outras áreas sociais e vice-versa é de fundamental importância para o entendimento mais completo das questões linguísticas. Nesse caso, sabe-se que o portunhol pode ser utilizado para fins comerciais, no caso de situações fronteiriças, independe da classe social do falante, visto que, inclusive, é um fenômeno idioletal, e nem sempre pode ser associado à instrução ou moradia do falante.

Entendemos como portunhol, portanto, a tentativa comunicativa de parte de falantes monolíngues em espanhol ou português na base perceptiva de que a semelhança 
entre ambas as línguas permite um alto grau de intercompreensão. Pode ser episódico e esporádico, ou seja, só acontece em determinadas situações. Segundo Fernández e Roth (2007, p. 77), "la denominación portuñol se aplica más propiamente a la mezcla de las lenguas española y portuguesa producida por desconocimiento de alguna de ellas o como consecuencia de un aprendizaje deficiente".

Já o português uruguaio é uma variedade linguística falada como língua materna pelos uruguaios há séculos, o que pressupõe também um processo de construção linguística em que intervêm fatores históricos e identitários.

Mota (2012, p. 130) afirma que "o português do Uruguai (que neste trabalho tratamos como portunhol) é, então, uma das línguas constitutivas dos sujeitos que compõem a sociedade que habita a fronteira uruguaio-brasileira [...]". Faulstich (1997, p. 3, 6 e 9) também admite que o português ou o fronteiriço do sul do Brasil pode ser denominado portunhol ou variedade mista. Adiante a autora afirma que o contato linguístico na fronteira Brasil-Uruguai resulta numa nova língua.

Todavia, em nosso trabalho, não concordamos com a associação do portunhol, da interlíngua ou do pidgin ao que se fala, em geral, na fronteira por algumas razões:

i. O portunhol não é língua, pois não é uma variedade falada como língua materna, mas apenas uma tentativa de comunicação temporária entre monolíngues.

ii. Estamos fazendo a diferenciação social e linguística entre portunhol e português uruguaio, uma vez que o primeiro seria uma comunicação momentânea, e o segundo a variedade linguística realmente falada como língua materna pelos uruguaios da fronteira;

iii. Quando há bilinguismo social, ou seja, quando há a convivência partilhada na comunidade de línguas maternas adquiridas, já não se pode falar de interlíngua nem de portunhol, como é o caso dos uruguaios que falam português e espanhol como língua materna na fronteira;

iv. O português e o espanhol na fronteira são adquiridos pelos uruguaios, diferentemente do portunhol, que é um código apenas para uma comunicação rápida, e da interlíngua, que é aprendida 
como L2 ou língua estrangeira dentro de um bilinguismo individual;

v. Contrariamente à realidade da fronteira, a ideia da interlíngua se baseia na crença de que um aprendiz de L2, em qualquer momento particular de sua sequência de aprendizagem, usa um sistema linguístico que não é nem a L1 nem a L2, ou seja, é simplesmente um sistema intermediário entre L1 e L2, que vai avançando segundo o nível da competência em L2 aumenta.

vi. Portunhol e pidgin não são sinônimos, porque pidgin é um meio de comunicação que surge quando há contato de línguas mutuamente ininteligíveis durante muito tempo (COUTO, 2009, p. 99). Além disso, pode tornar-se um crioulo e, portanto, língua materna. No caso do portunhol, ambas as línguas são inteligíveis, o contato não precisa ser duradouro e jamais será língua materna de alguma comunidade.

Ainda há outras nomenclaturas sobre o "falar" da fronteira, caracterizadas por alguns estudiosos precursores dos estudos fronteiriços, como é o caso do fronterizo, DPU (dialetos portugueses do Uruguai) e PU (português uruguaio), que serão vistos adiante.

\subsubsection{Fronteiriço}

Na próxima obra de Hensey (1972), ele parte do conceito de interlecto para o de fronterizo. Uma passagem importante na sua obra (1972, p. 77) é quando há o reconhecimento de que a fonologia do dialeto do português pode ser descrita diferentemente do português e do espanhol padrão. Nesse sentido, comparando os três sistemas, o autor afirma que fronterizo pode ser derivado do português padrão remodelado, em contato com o espanhol.

Em vários outros trechos do livro, o autor nos deixa confusos sobre o que seria de fato o fronterizo. Hensey (1972, p. 78) iguala fronteiriço ao português menos padrão e diz que o fronterizo, de base portuguesa ou espanhola, seria a língua de alguns uruguaios que não são bilíngues. Depois afirma que é difícil distinguir fronterizo do português imperfeito. 
A dicotomia feita pelo autor é que o português de bilíngue seria falado pela classe média, e o fronterizo seria falado primeiro pela classe trabalhadora, supostamente monolíngue. Essa realidade descrita na época de Hensey é muito distinta da que presenciamos em Aceguá, uma vez que grande parte da comunidade uruguaia da fronteira é bilíngue, independentemente de classe social.

Outra observação importante que fazemos é sobre o cuidado com termos pejorativos que não traduzem a realidade linguística da fronteira, como as adjetivações de "português remodelado" (HENSEY, 1972, p. 77), "português imperfeito" (HENSEY, 1972, p. 78), “problema de linguagem” (ELIZAINCÍN, 1992, p. 90). Essas terminologias possuem um juízo de valor que deve ser evitado em estudos científicos sobre a língua.

Com relação à nomenclatura do falar da fronteira, Elizaincín, Behares, Barrios (1987, p. 12-13) retomam o conceito de fronterizo, proposto por Rona (1963) e Hensey (1972), e distinguem-no do portunhol:

\footnotetext{
"Portuñol" es la designación más neutra que puede oírse de miembros cultos de la comunidad urbana. Ha sido construída en base a otros términos similares tales como "franglais" o "spanglish". "Fronterizo" designa a las hablas en base a la geografía dialectal; ha sido usado en publicaciones científicas, por ejemplo por José P. Rona y también (sin traducir) por F. Hensey en sus múltiples aportes al tema. Sin embargo, ha tomado también connotaciones peyorativas, motivo por el cual (aparte el hecho de que la designación es demasiado amplia: en realidad cualquier lenguaje que surja y se use en una frontera es un "fronterizo") no lo hemos usado en general en nuestros trabajos sobre el tema.
}

Entretanto, a distinção entre portunhol e fronterizo não parece ser tipológica, ou seja, parece que estes termos se referem a mesma coisa, mas com nomes diferentes dados por grupos diferentes. Como o fronterizo de Rona e Hensey também era associado a dialeto misto e, portanto, à pidginização, o que houve foi apenas uma mudança de nomenclatura sem alteração de seu significado, ou seja, sem mudar a concepção do que se entendia por esse falar na fronteira.

\subsubsection{DPU (Dialetos Portugueses do Uruguai) e pré-pidgin}

Nessa mesma obra de 1987, por considerarem esses termos pejorativos, Elizaincín, Behares, Barrios modificam a denominação fronterizo para Dialetos 
Portugueses do Uruguai (DPUs), caracterizados assim por terem a base morfossintática portuguesa.

Ao denominar os DPUs, Elizaincín, Behares e Barrios (1987, p. 25) novamente inserem-nos em um continuum pré-pidgin, o que não se sustenta, pois os próprios autores afirmam que os pré-pidgins são efêmeros. Se os DPUs têm séculos de existência, é, no mínimo, inconsistente que os autores classifiquem os DPUs como prépidgin, já que seriam efêmeros. A condição de repressão social pode explicar a lenta evolução (transformação) dos DPUs.

Novamente, o que se observa é uma mudança apenas na terminologia, mas a concepção de um pré-pidgin ou de uma mistura de línguas permanece igual. Se um pidgin por si só não é língua materna de ninguém, muito menos o pré-pidgin o será.

Em Aceguá, se escuta bastante a nomenclatura de DPU dentro das escolas uruguaias, na tentativa de não mais se usar a denominação portunhol, por conta do seu caráter estigmatizado e popular. Entretanto, o termo portunhol ainda é reproduzido por muitos membros da comunidade local, e não somente por membros cultos da comunidade urbana como afirmavam Elizaincín, Behares e Barrios (1987, p. 12).

Sturza (2005) também questiona a classificação linguística e discute a criação de uma terceira língua como uma das práticas linguísticas da população fronteiriça, que incluem o portunhol e os DPUs.

\footnotetext{
Nessa fronteira, do Rio Grande do Sul com os países da bacia do rio da Prata, sobretudo na zona fronteiriça do Brasil com o Uruguai, há ainda uma terceira "língua", que não é nativa, não é a do imigrante, não é a do Estado. É a que funciona como mais uma nas práticas linguísticas de grande parte da população fronteiriça e que resulta do cruzamento das línguas portuguesa e espanhola, da extensão ou do influxo de uma língua em território lingüístico da outra.

Essas práticas foram designadas de dois modos: o portunhol - que abrange uma maior extensão de contato, ainda que com caracterizações discutíveis e pouco definido enquanto fenômeno de contato linguístico, e os DPUs Dialetos Portugueses do Uruguai -, que gozam de um reconhecimento maior, de pesquisas e estudos regulares da linguística internacional. (STURZA, 2005, p. 48).
}

Como já argumentamos, a realidade da fronteira é do português e do espanhol como línguas maternas, e não de uma terceira língua diferentemente do português e do espanhol. Além disso, o português uruguaio já é reconhecido pelo Uruguai, ainda que seja o espanhol a língua nacional e utilizada pelo Estado. A constituição uruguaia não indica o espanhol como língua oficial, mas se refere ao espanhol como a língua nacional (CARVALHO, 2008, p. 65). 
Na segunda parte da citação de Sturza (2005, p. 48), não fica claro se o portunhol e os DPUs fazem parte dessa terceira língua e qual a diferença de fato entre os dois termos. Essas definições de língua vêem-na apenas como sistema, ora de regras interacionais, ora de regras sistêmicas.

Na fronteira Brasil-Uruguai, especialmente em Aceguá, a maioria dos falantes uruguaios são bilíngues. Por isso, do ponto de vista linguístico e científico, não se pode confundir o portunhol com o português da fronteira, porque o português falado no Uruguai, especificamente em Aceguá, é língua materna e existe há mais de três séculos, pois se trata de comunidades bilíngues que falam o português e o espanhol, uma vez que o contato linguístico é estável. No caso do portunhol, seria uma tentativa de monolíngues de se comunicarem, especialmente em situações comerciais na fronteira.

Assim sendo, existe um senso comum associado à existência do portunhol que sempre esteve vigente, e os próprios moradores da fronteira se identificam com esses discursos veiculados pela população em geral e também pela mídia. Com relação aos meios midiáticos, Carvalho (2008, p. 66-67) já havia estudado a influência da televisão sobre a urbanização do português uruguaio a partir da "atitude dos falantes em relação às culturas ao seu redor que permite que a televisão se torne uma fonte útil de modelo linguístico".

Elizaincín, Behares e Barrios (1987, p. 12) já registravam algumas maneiras pelas quais os falantes se referiam à variedade local deles como Brasileiro (em toda a zona fronteiriça entre Brasil e Uruguai), Bayano e Carimbão (especificamente no departamento de Tacuarembó). As nomenclaturas portunhol, entreverado, mistura são bem recorrentes na fala dos aceguaenses também, como a de um jovem uruguaio, filho de pai brasileiro e mãe uruguaia, que, ao ser questionado se a mãe falava o português, responde:

1. Fala, fala pouco, entreverado, um portunhol mais entreverado, porque em realidade não falemo português, português... é um portunhol.

O próximo exemplo é de um senhor uruguaio que fala sobre a dificuldade que tem nas duas línguas, português e espanhol, tanto na fala como na escrita, diferentemente de seus filhos brasileiros.

2. Isso aqui, a cultura é mais ou menos a mesma, de toda a gente se confunde. Pra nós, não temos... vocês que vêm de longe podem notar a diferença, mas pra nós, a gente criou um dialeto pra falar, a gente fala 
portunhol, não fala nem espanhol nem português. Eu, por exemplo, hoje, não consigo escrever nenhuma das duas línguas de forma correta. Eu não escrevo nem português correto, nem espanhol. Eu faço uma mistura, eu troco o $C$ pelo $Z$, eu troco... nós no espanhol não temos $C$. Eu estou reaprendendo com eles, eles que estão me ensinando, porque eles estão indo, eles são uruguaios, mas estudam em escola brasileira, então a [...] que já está na oitava série, que eu pergunto: como escreve tal coisa? Como é que escreve tal outra? Porque pra mim [...]

Ainda que boa parte dos falantes tenha domínio do português, percebe-se que há certa insegurança linguística entre os uruguaios falantes de português na fronteira. Assim, para não se comprometerem em dizer que falam português, porque são conscientes de que em vários casos não é um português padrão, eles preferem chamá-lo de portunhol. Esses depoimentos nos dão indícios de ser uma fala desprestigiada pela comunidade, porque há constantemente uma conotação inferior da fala local, que não é nem o espanhol nem o português, como eles gostariam que fosse, mas sim uma "mistura" das duas línguas, como eles mesmos se referem à variedade linguística da fronteira.

\subsubsection{PU - Português Uruguaio}

Diante de todas essas tentativas de designar o falar da fronteira, torna-se crucial a denominação português uruguaio proposta por Carvalho (2003), que afirma que a percepção da mistura é mais ideológica do que real ou científica. Segundo a autora, do lado brasileiro, fala-se o português do Rio Grande do Sul e do lado uruguaio fala-se o espanhol e o português, sendo o português uruguaio um contínuo que oscila num continuum entre o português culto urbano e o português não culto rural. Portanto, o português uruguaio não é uma língua diferente, tendo em vista que os dialetos falados na fronteira são variedades de português e de espanhol. A respeito da urbanização do PU, Carvalho (2008, p. 65-66) confirma que

a urbanização que sofreram as comunidades fronteiriças na última metade do século XX tem permitido uma maior receptividade e sensibilidade ao português brasileiro urbano (PB), a variedade falada no país vizinho, o que tem causado o PU local a mover-se na direção do dialeto mais prestigiado. Esta tendência pode ser vista através da incorporação de novas variantes fonológicas na fala de certos grupos, que, ao emprestar formas do PB urbano, iniciam uma mudança lingüística desde variantes extremamente estigmatizadas do PU a variantes urbanas brasileiras, as quais se assemelham mais ao padrão ideal. A urbanização do PU, desta maneira, força um movimento na direção contrária de sua origem híbrida e rural, caminhando em direção à assimilação de características linguísticas que são esterotipicamente brasileiras, como resultado do desejo de emular aos 
falantes das comunidades urbanas monolíngües do Brasil, cujo dialeto é mostrado diariamente na televisão.

Posto isso, o português uruguaio falado pelos bilíngues uruguaios, nas zonas mais urbanas, é parecido com o português brasileiro, porque foi urbanizado. $\mathrm{O}$ português uruguaio rural é um dialeto falado nas zonas rurais, que corresponderia, portanto, ao "fronterizo" de base portuguesa de Rona (1963) (CARVALHO, 2003).

Assim, acreditamos que os estudos sobre a variedade do português no Uruguai podem ser divididos em antes e depois da designação de haver no Uruguai uma variedade linguística legítima do português, como existe em todas as regiões brasileiras e em outros países de língua portuguesa. Essa classificação proposta por Carvalho (2003) foi fundamental para analisar os estudos fronteiriços e legitimar de fato a realidade linguística existente na fronteira entre Brasil e Uruguai.

A partir do trabalho de linguistas nas fronteiras entre Brasil-Uruguai, com Carvalho (2003b e 2008), Meirelles (2006, 2009 e 2011) e Waltermire (2006) em Rivera, Douglas (2004) em Artigas, Amaral (2008) em Chuí e Pacheco (2013) em Aceguá, o português uruguaio, falado por comunidades bilíngues, é caracterizado por (1) fenômenos linguísticos do português rural e não padrão brasileiro, porque mesmo o português uruguaio mais urbanizado ainda tem elementos do português rural e (2) empréstimos e code-switching do espanhol.

Como não foram encontradas diferenças sistemáticas que justificassem diferentes dialetos, pode-se dizer que há continuidade (ou continuum) dialetal entre as duas variedades linguísticas (português uruguaio e português brasileiro) ao longo da fronteira Brasil-Uruguai, conforme previsto por Carvalho (2003b e 2008). Meirelles (2006, 2009 e 2011) mostra que há um só inventário fonológico nos dois lados da fronteira, e Pacheco (2013) confirma a continuidade ao detectar o pronome a gente no português uruguaio.

Assim, português uruguaio é o português falado como língua materna por uruguaios bilíngues na zona fronteiriça. O português brasileiro da fronteira seria o português falado pelos brasileiros do lado do Brasil em Aceguá, que faz parte do português gaúcho, do extremo sul.

Em termos políticos, faz toda a diferença designar um falar como língua ou uma variedade linguística, porque permite colocar as línguas em pé de igualdade e importância (CARVALHO, 2006). Por isso, a designação de português uruguaio proposta por Carvalho (2003) foi uma ruptura importante no contexto atual. Como já 
dizia Max Weinreich, pai de Uriel Weinreich, "língua é um dialeto com exército e marinha", o que corrobora a discussão sobre a influência política e ideológica da noção de língua.

O reconhecimento científico e linguístico do português uruguaio como língua materna do Uruguai também foi consequência da luta constante e da participação recente de linguistas em comissões de educação no Uruguai voltadas para a inserção do ensino bilígue nas escolas uruguaias, em período integral. Portanto, a década de 2000 é marcada por um verdadeiro reconhecimento educacional da variedade de português falada no Uruguai (CARVALHO, 2006).

A seguir, serão exemplificados fenômenos linguísticos variáveis do português aceguaense, tanto do lado uruguaio como do lado brasileiro. Assim, é possível visualizar melhor que o tipo de variação linguística que ocorre no português uruguaio da fronteira é semelhante ao português da fronteira e do Brasil como um todo, corroborando a premissa de que o português uruguaio é uma variedade linguística do português brasileiro.

\subsection{Fenômenos linguísticos comuns aos falantes brasileiros monolíngues e aos falantes uruguaios bilíngues de Aceguá}

É importante analisar que tipo de variação linguística ocorre em situações de contato de línguas, porque os padrões variáveis podem nos mostrar até que ponto as gramáticas variáveis são permeáveis. Além disso, é uma prática comum, apesar de equivocada, confundir variantes não padrão com variantes de contato (POPLACK, 1993).

No caso do português uruguaio de Aceguá, os fenômenos identificados nas entrevistas são comuns ao português brasileiro gaúcho da fronteira e, também, às variedades monolíngues do português brasileiro de forma geral. Assim, há indícios linguísticos de que o português uruguaio é, de fato, uma variedade do português brasileiro.

Entre os fenômenos comuns do português brasileiro de outras regiões do Brasil $^{30}$, temos exemplos variáveis semelhantes na morfologia e na sintaxe do português de Aceguá como um todo, tanto dos brasileiros quanto dos uruguaios de nossa amostra.

\footnotetext{
${ }^{30}$ Carvalho (2003, p. 132-133) descreve alguns desses fenômenos $(3,4,6,8)$ e outros mais que ocorrem no português fronteiriço de Rivera, no Uruguai.
} 
Nos exemplos do português brasileiro de Aceguá, os dados são de um homem, adulto, brasileiro e com ensino superior. No exemplo do português uruguaio (PU) de Aceguá, os dados são de um homem, jovem, uruguaio e com ensino médio.

- Ausência de marcador plural em algum elemento do sintagma nominal.

PB: Os despacho que tu assinar tu não pode levar multa.

PU: As pessoa mais veia assim ... não te fala o português.

- Pronúncia como semivogal do fonema lateral palatal $l h$, semelhante ao português de áreas rurais.

PB: Tô trabaiando...

PU: Uma pessoa veia...

- Mim seguido de preposição na posição de sujeito da segunda oração.

PB: E eles me pediram para mim mandar a gravação.

PU: É, sim, depois legalizei para mim poder trabalhar do lado brasileiro.

- Pronomes retos em lugar de clíticos

PB: Pegaram ele, acharam a pessoa certa.

PU: A [...] vai colocar ele lá.

- Uso de "tu" alternando com "vocể" juntamente com a ausência da flexão verbal quase categórica nas entrevistas.

PB: Aí tu bota água morna aqui, a morna, e aí deixa inchar.

PU: Tinha ido jogar na Colônia, não sei se tu conhece.

PB: Mas agora para entrar no Uruguai, você tem que pagar, no mínimo, cinquenta, não me lembro, entre cinqüenta e sessenta reais numa carta verde.

PU: Não sei o que mais Cíntia. Eu tenho que comenzar agora no meu programa. Você quer escutar um pouquinho o programa?

- Substituição do sufixo de primeira pessoa do verbo da primeira conjugação por -emo, semelhante ao português de áreas rurais.

PB: Nós falemo as duas coisa (tempo presente).

PU: Nós viajemo uma vez, ano retrasado, a quatrocentos e pico quilômetros daqui, e falando assim, pensando que nós era um deles e coisa... (tempo passado)

- Uso de a gente como primeira pessoa do plural

PB: Então vem o cliente, a gente apresenta a mercadoria, libera a mercadoria, e aí é a aprovação do fiscal, se ele carimbou tu ta aprovado.

\footnotetext{
${ }^{31}$ Nas entrevistas de Aceguá, há poucos dados de "você".
} 
O português da fronteira, tanto do lado brasileiro quanto uruguaio, também se assemelha bastante ao português de áreas rurais do Brasil, principalmente nos exemplos "trabaiando" e "nós joguemo". O exemplo de segunda pessoa do singular, com ausência da flexão verbal correspondente ao "tu", é semelhante ao que ocorre na maior parte do Rio Grande do Sul e do Brasil. Os demais exemplos acima também são facilmente encontrados em outras variedades brasileiras.

Se retomarmos parte do segundo exemplo da seção 2.2.5, veremos que, de fato, se trata da alternância entre nós e a gente no português uruguaio:

Pra nós, não temos... vocês que vêm de longe podem notar a diferença, mas pra nós, a gente criou um dialeto pra falar, a gente fala portunhol...

Portanto, o português uruguaio e o português brasileiro dialogam entre si e são semelhantes em vários aspectos linguísticos, como os exemplos citados acima, que ocorrem em diversas variedades do português brasileiro. Todavia, quando há contato linguístico direto, também é possível identificar fenômenos específicos dessa interação linguística (POPLACK, 1993, p. 255 e MEYERHOFF, 2009), que serão analisados a seguir.

\subsection{Consequências do contato linguístico}

Em situações de contato, além de fenômenos variáveis internos, do próprio idioma, que são semelhantes ao que encontramos nos equivalentes dialetos monolíngues, há situações prototípicas resultantes do contato linguístico.

Meyerhoff $(2009$, p. 313, 314) questiona até que ponto a variabilidade de uma língua aparenta ser parcial ou completamente replicada em outra língua. Assim, fornecemos a base para conexões entre sociolinguistas e crioulistas, e também entre o contato linguístico e o crescente campo dos estudos comparativos sobre variações linguísticas. Para Meyerhoff (2009, p. 298), entre os resultados linguísticos do contato 
ao longo do tempo, em comunidades e dentro do próprio repertório dos indivíduos, temse o calquing $^{32}$, a replicação e a transferência.

O calquing é geralmente usado para referir-se à tradução direta, morfema por morfema ou palavra por palavra, de conceitos e estruturas sintáticas que se originaram na outra língua. A replicação (em vez de transferência ou interferência) sugere cópia e diferenciação ao mesmo tempo e envolve alguma nativização ou alteração do modelo na réplica, ou seja, há uma língua modelo na qual o padrão se origina historicamente, e uma língua réplica que adota o padrão como resultado do contato com o modelo. A transferência, em contraposição, sugere realocação de um traço ou subsistema como um todo e a interferência sugere problemas a respeito da língua-alvo (MEYERHOFF, 2009, p. 298-299).

No contexto da comunidade de Aceguá, na fronteira Brasil-Uruguai, temos como exemplo de transferência gramatical "Tu vais a ver", falado por um brasileiro, faixa etária intermediária, nível médio de escolaridade e proveniente de Aceguá. Essa mudança é na estrutura sintática da perífrase verbal e, nesse caso, a referência é a perífrase do espanhol, composta pelo verbo auxiliar ir + preposição a + verbo no infinitivo.

As possibilidades linguísticas que surgem de um contato linguístico são entendidas como um fenômeno social, e não como um fenômeno de L2. O significado social da mudança linguística é exemplificado por meio do comportamento, atitude e percepção do falante (POPLACK, 1993, p. 254). Posto isso, exemplificaremos alguns empréstimos lexicais e code-switchings que ocorrem no corpus de Aceguá.

\subsubsection{Empréstimo Lexical}

De acordo com Weinreich (1963), é possível entender apenas a direção da interferência de uma língua, ou seja, que língua está interferindo em outra língua e em quais níveis linguísticos: fonético-fonológico, gramatical ou lexical. Já Thomason (2008, p. 52 e 53), entende que nem a direção é possível prever numa situação de contato linguístico.

\footnotetext{
${ }^{32} \mathrm{O}$ termo calquing em inglês indica palavras que se formaram na língua por meio de "empréstimos", em geral advindos uma tradução literal com sentido de uma língua para outra, como o caso de "skyscraper", que em português resultou em "arranha-céu".
} 
Com relação às interferências de natureza linguística, tem-se o empréstimo lexical, que é a adaptação do material lexical aos padrões morfológicos e sintáticos (e geralmente fonológico) da língua destinatária (POPLACK, 1993, p. 256), como também relata Meyerhoff (2009).

Escobar (2001, p. 79-80 e 90) afirma, ao analisar o empréstimo lexical do Quechua no espanhol peruano, que as condições sociolinguísticas, a urbanização, o grau de bilinguismo dos falantes e o grau de interação social e linguístico entre a comunidade monolíngue e bilíngue definem os fenômenos linguísticos oriundos do contato de línguas. No caso do nosso estudo, a comunidade bilíngue seria a do Uruguai e a comunidade monolíngue seria a do Brasil, ambas inseridas em um continuum que vai do mais rural para o mais urbano.

Em um contato de línguas, o lócus considerado como domínio do empréstimo por excelência é o léxico, ou seja, as interferências ou empréstimos lexicais são mais comuns e recorrentes no léxico e no nível fonético-fonológico (SANKOFF, 2002, p. 5 e 19). Assim, exemplificaremos a seguir alguns casos de empréstimo lexical do espanhol em direção ao português brasileiro de Aceguá e em direção ao português uruguaio de Aceguá, encontrados no nosso corpus de entrevistas. Os dados foram retirados de uma entrevista com um homem, adulto, brasileiro, com ensino superior.

\section{Empréstimo do espanhol no português brasileiro da fronteira de Aceguá}

- $\quad$ O meu tava muito peleado (falando do telefone estragado)

- Entrevistador: Quanto deu?

Entrevistado: 15 con 50. (a forma espanhola de dizer o preço)

- $\quad$ Entrevistador: Ah, então é muito mate né?

Entrevistado: Dá uns quantos. (sinônimo de "muito" ao se referir à quantidade de mate que eles consomem diariamente)

- $\quad$ Entrevistador: Aí cê coloca até aqui também.

Entrevistado: É, até aqui a boca, não pode passar do da taipa, assim como está servido o meu. Aí depois ela vai inchar, baixou toda a água, e aí tu segue servindo a água quente. (falando sobre o mate)

- Vocês querem mate muchachas? Quer? (Interação com duas outras moradoras de Aceguá)

- $\quad$ Eu era largo / Tirei o óculos um dia, eu fui arrumar porque ele ficou largo. ("Largo" é usado em espanhol para se referir a alguém gordo ou algo grande)

- $\quad$ Passa, passa (sinônimo de entra, pode entrar). 
- $\quad$ Cangrejo (adjetivo usado em tom pejorativo se referindo a moradores do bairro em Noblia).

- Aqui a gente fala que aqui é frio de ranguear cusco de ranguear cachorro. (Expressão que significa muito frio, como se diz em Aceguá, na parte brasileira).

- $\quad$ Molestar (pertubar).

Há também outros dados retirados de cardápios e placas de restaurantes brasileiros, como lanchería (lanchonete), chivito/sanguiche (sanduíche) e chosco (quiosque). Nos próximos exemplos, o empréstimo é do espanhol em direção ao português uruguaio de um homem, jovem, uruguaio, de nível médio.

\section{Empréstimo do espanhol no português uruguaio da fronteira de Aceguá}

- $\quad$ Entrevistador: Tá bom, então obrigada viu, prazer viu. Entrevistado: Bueno. $\underline{\text { Gracia }^{33}}$ igual.

- $\quad$ Entrevistador: Engraçado que vocês pequenininho assim, os meninos pequenininho, cavalo...

Entrevistado: Não, aqui na região, eu, no mais, empecei a andar $^{34}$ a cavalo com oito anos, sete anos.

Entrevistador: Eu vi gente menor.

Entrevistado: Ah sim, pequenininho assim.

Entrevistador: Eu falei: gente, vai cair, menininho! Meu Deus.

Entrevistado: Sim, aqui desde de pequeno já quem gosta, já empieza a andar a cavalo. ${ }^{35}$

- $\quad$ Entrevistado: Nascemo três, no Uruguai é um.

Entrevistador: Ah é? Aí no Uruguai é um, aí no Brasil três?

Entrevistado: Três.

Entrevistador: E aí, algumas você dá três, outras não?

Entrevistado: Sim. É cada complicación ${ }^{\mathbf{3 6}}$ por isso.

Entrevistador: Teu nome é TIT?

Entrevistado: JEF. TUC me dicen. ${ }^{37}$

- $\quad$ No Uruguai fazia três anos que vinha para ser o deporte mais famoso no Uruguai, principal. (sobre Raí de cavalos).

- Entrevistado: E ai nós falemo, expliquemo ${ }^{38}$, nós somo de aceguá, falemo $^{39}$ português. E aqui, os canais que tem agora, tem cable ${ }^{40}$ que passa uruguaio, mas é quase tudo brasileiro.

Entrevistador: Daqui não vai? Globo e tudo né?

Entrevistado: Sim, oímo ${ }^{41}$ a Globo, oímo esses canal de esporte e coisa.

\footnotetext{
${ }^{33}$ Bom. Obrigado igual.

${ }^{34} \mathrm{No}$ geral, comecei a andar a cavalo com oito anos, sete anos.

${ }^{35}$ já começa a andar a cavalo.

${ }^{36}$ complicação.

${ }^{37}$ dizem.

${ }^{38}$ Falemo e expliquemo: tempo pretérito perfeito.

${ }^{39}$ Somos e falemo: tempo presente.

${ }^{40}$ cabo.
} 
- $\quad$ Entrevistador: Rivera diz que é bem maior né?

Entrevistado: Rivera é grande, Rivera é cidade, aqui é uma cidade, como dizem no Uruguai, uma villa. Cada, pa ser povo tem que ter tantas mil

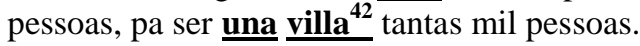

- $\quad$ Entrevistador: Aqui quantas pessoas?

Entrevistado: Aqui tres e pouquinho.

Entrevistador: Da parte do Uruguai? Ou tudo?

Entrevistado: Tudo, todo, todo.

Entrevistador: Será que é só isso?

Entrevistado: É que é pouco né, assim. Aqui no Uruguai, na parte do Uruguai, não é mais do que isto, porque la volta que faz.

- $\quad$ Entrevistador: Tu já trabalhou no free shop $^{44}$ ?

Entrevistado: Não, não quis, não quis. Queriam que mandasse currículo, eu digo: não é vida, porque tem que estar de lunes a domingo ${ }^{45}$ e não posso fazer nada.

- $\quad$ Entrevistador: Legal. E a fronteira, tanto a parte do Uruguai quanto a parte do Brasil fala mais português mesmo?

Entrevistado: Sim, sim. Todos falam português. E o que não fala, entende. Porque as pessoa mais véia assim, tem uma pessoa véia que não te fala o português, mas são $\underline{\text { mui }}^{\mathbf{4 6}}$ veia, mas algo entende. Com o tempo vai entendendo, porque tem o filho né.

- $\quad$ Entrevistador: E vocês torcem pra que? Que time?

Entrevistado: Eu do Brasil, sou do Grêmio. Grêmio e Brasil. No futebol uruguaio, agora que o Cerro Largo ascendeu $^{47}$ pra primeira, subiu pra primeira divisão, mais o Cerro Largo, mas não, não acompanho muito. Futebol que mais acompanhemo é o brasileiro né.

- $\quad$ Sim. Os uruguaios são mais. Eu não sei se é porque nunca fizeram nada, (...) que passa es que vocês passam cinquenta anos pra ganhar um mundial. E aí eles ficam picado, e nós zoamo muito eles. Pero, incluso ${ }^{48}$ aqui, quando o Uruguai ganhou a Copa América, vinha gente do Brasil e fizeram uma caravana bárbara aí.

- $\quad$ Sim, veio todo o lado brasileiro, que isto aqui não dava pá caminar de gente. (Conversa sobre a copa mundial de 2010)

- $\quad$ Entrevistador: É, pra próxima Copa já fica mais difícil.

Entrevistado: Sim. Não devem de ir pra próxima Copa. Forlan capaz que $\underline{\text { vaya }^{50}}$ porque é o símbolo uruguaio. Pero, já fica mais difícil.

- $\quad$ Entrevistador: Até mais.

Entrevistado: Cualquier $^{51}$ coisa...

\footnotetext{
${ }^{41}$ Ouvimos: tempo presente.

${ }^{42}$ uma vila.

${ }^{43}$ tudo, tudo.

${ }^{44} \mathrm{Na}$ região fronteiriça, existem os Duty Free Shops (lojas livres de impostos) que são localizados no

Uruguai e só podem vender para brasileiros.

${ }^{45}$ Segunda a domingo.

${ }^{46}$ A expressão mui, que significa muito, também é utilizada no Sul do Brasil e no português europeu.

47 subiu.

${ }^{48}$ mas, inclusive.

${ }^{49}$ caminhar.

${ }^{50}$ vai. (utilizado no subjuntivo do espanhol)

51 qualquer.
} 
Nos primeiros exemplos, o empréstimo do espanhol no português brasileiro da fronteira de Aceguá concentra-se mais em adjetivos, verbos e substantivos, enquanto nos outros exemplos o empréstimo no português uruguaio de Aceguá é mais amplo, atingindo adjetivos, verbos, substantivos, artigos, quantificadores, conjunções, pronomes indefinidos e marcadores discursivos. No geral, nota-se que os empréstimos lexicais são mais recorrentes e produtivos em palavras corriqueiras na fala da comunidade. Em situações de contato de línguas, sem que haja o surgimento de outra língua, dificilmente a interferência ocorre na morfologia (não encontrada em nosso corpus) e na sintaxe (como o caso de "Tu vais a ver"). Além disso, há uma acomodação como Poplack (1993) explica. Todas essas interferências também são passíveis de quantificação, mas não é o foco do nosso trabalho.

Como empréstimo lexical do espanhol, Hensey (1972, p. 74-75) cita os termos "gracias", "buena tarde”, usuais no português da região fronteiriça. Em Aceguá, é muito comum ouvir essas expressões entre brasileiros e uruguaios. Todavia, esses empréstimos ocorrem menos entre os brasileiros fronteiriços.

\subsubsection{Code-switching}

Code-switching 52 ou "alternância de código" é o uso alternado de duas ou mais línguas por falantes bilíngues ou multilíngues em uma mesma interação conversacional. O code-switching é alternância (e não a mistura aleatória) de duas línguas, que independe do interlocutor, e ocorre dentro de uma mesma interação verbal e dentro de uma mesma configuração sintática, com regras de cada uma das línguas, segundo Poplack (1993).

No entanto é importante não utilizar a palavra "mistura", porque esta parece implicar que não há regras que envolvem a interação verbal, o que não é o caso. O que se chama de mistura é, muitas vezes, o uso alternado de línguas, que tem regras sociais e linguísticas a depender das situações formais ou não-formais dentro de uma situação intercultural.

\footnotetext{
${ }^{52}$ Para maiores informações sobre code-switching, conferir alguns trabalhos como Carvalho (2012), Amaral (2008), Montes-Alcalá (2005), Woolard (2006), Lipski (2005), Poplack (1993, 2004), MyersScotton (1997h).
} 
Para Poplack (1993, p. 255), code-switching é a justaposição de sentenças ou fragmentos de sentenças com regras morfológicas e sintáticas da língua proveniente. A alternância se dá entre sentença (sentencial) ou dentro dela (intrassentencial).

Para Muysken (2013, p. 152), em toda comunidade bilíngue, alguns falantes podem alternar entre trechos de discurso em diferentes línguas, sujeito a condições pragmáticas específicas (Muysken, 2000). A complexidade e a relação entre esses trechos de discurso estão sujeitas ao que aparenta ser uma hierarquia:

sentenças isoladas < orações coordenadas < orações subordinadas adverbiais < locuções adverbiais < argumentos deslocados $<\ldots$

Esta hierarquia implica que, sempre que os falantes de uma comunidade bilíngue alternam entre duas orações coordenadas ou entre uma oração subordinada adverbial e uma oração principal (o que acontece com frequência), haverá casos de verdadeira alternância intersentencial (entre sentenças). Contudo, alternância entre unidades menores, como elementos deslocados, serão menos frequentes.

Carvalho (2012, p. 1) analisa as principais questões sobre code-switching. O consenso atual é de que o code-switching é um comportamente linguístico comum entre os bilingues que o utilizam devido a vários contextos de interação na comunidade. Pode ser visto pelo senso comum como incapacidade de falar uma língua de cada vez, como aquisição incompleta (por não dominar ainda as duas línguas) ou como convergência linguística (incapacidade de separar as duas línguas). No entanto, as pesquisas linguísticas como a de Amaral (2008) mostram que o code-switching é, na verdade, marca de competência bilíngue, governado por regras e utilizado a partir de diversas estratégias discursivas e sociais.

Em uma entrevista gravada na escola pública uruguaia, estávamos conversando, eu e duas professoras, uma uruguaia (entrevistada 1) e a outra brasileira com dupla nacionalidade (entrevistada 2), que dá aulas de português para os alunos uruguaios. Ao longo da conversa, as professoras mudavam a língua em uma mesma interação verbal constantemente.

Entrevistada 1: Entón, porque son diferentes experiencias. Eu acho que de la central lá... (falando sobre o início do ensino bilíngue nas escolas uruguaias da fronteira).

Pesquisadora: Daqui a gente não tem tanta informação ainda.

Entrevistada 1: Eso que é a primera. Digamos eso. ?Fue cuando fuiste en el interior? ?En que año:

Entrevistada 2: ?Cerro Largo:

Entrevistada 1: Si. 
Entrevistada 2: Cerro Largo 2004. Rivera y Artigas 2003.

Entrevistada 1: 2004 ya, hace tanto tiempo...

Entrevistada 2: Sí, desde ai eu trabalho aqui ... já, este é o meu oitavo ano já aqui.

Nesse exemplo, as professoras alternam do português para o espanhol e viceversa na minha presença. A professora uruguaia (1), que não é bilíngue, alterna palavras portuguesas e espanholas (em itálico) enquanto a professora brasileira (2), bilíngue, não alterna. Quando elas dialogam entre si ou com qualquer outro funcionário da escola, a tendência é a conversa ser toda em espanhol, uma vez que nesse ambiente de trabalho a política linguística determina a escolha da língua espanhola, por fazer parte de um grupo específico.

Assim, para Muysken (2013, p. 155, 156), fatores estruturais fornecem condições para que a "mistura" complexa se torne uma opção, mas vários fatores não linguísticos são igualmente essenciais para a ocorrência do code-switching, tais como:

- Competência: envolve a habilidade bilíngue.

- Modo de linguagem: uma mistura complexa não é propagada de forma uniforme ao longo de uma conversa bilíngue, mas agrupada em momentos do diálogo.

- Normatividade: uma mistura complexa é frequente quando normas monolíngues foram afrouxadas e os padrões convergentes emergiram.

- Atitude: quando há forte competição ou conflito político entre duas comunidades linguísticas, as misturas complexas tendem a diminuir.

- Idade: os tipos mais complexos de mistura de códigos foram documentados entre adolescentes e jovens adultos.

- Estilo: a maioria da mistura de códigos foi registrada a partir de conversas informais dentro de um grupo.

- Geração: a maioria dos casos de mistura de códigos complexa foi registrada a partir de falantes da segunda geração em comunidades de imigrantes.

No caso do code-switching ou code-mixing ou troca de código, o material lexical das duas línguas está presente, assim como a estrutura morfossintática de ambas as línguas. Na interferência, de Weinreich (1953), a influência mútua entre as duas línguas de um bilíngue envolve a estrutura morfossintáctica de dois idiomas, mas o material lexical é de apenas um deles (MUYSKEN, 2013, p. 147) e pode ser estável numa comunidade bilíngue. 


\subsubsection{Escolha de línguas}

No caso da escolha de línguas, a mudança pode ser na mesma interação verbal ou em interações diferentes, ao conversar direta ou indiretamente com outra pessoa no discurso. Mas, diferentemente de analisar os resultados, o enfoque é na escolha da língua $\mathrm{X}$, língua $\mathrm{Y}$ ou $\mathrm{YX}$. A escolha de língua se dá em função exclusiva do interlocutor, com o uso das duas línguas de forma autônoma. De acordo com Waltermire (2012, p. 515), a escolha de língua envolve o interlocutor e o contexto social, típico de uma comunidade diglóssica.

Um dos exemplos de escolha de língua aconteceu em Aceguá no momento das entrevistas. Um taxista brasileiro falava comigo em português quando, ao ver uma conhecida do Uruguai do lado do Brasil, mudou a língua e a interação verbal para o espanhol automaticamente para falar com a uruguaia. Interessante, ainda, é compreender que essa escolha de línguas é geralmente inconsciente para o falante. Outro fato vivenciado durante a coleta de dados foi em duas escolas uruguaias, uma de ensino fundamental e outra de ensino técnico. Em ambas as escolas, os alunos falavam em espanhol com os professores, mas se dirigiam aos colegas em português tanto na oralidade quanto na escrita de mensagens de celular.

Geralmente, o português é utilizado com a família e com os brasileiros, enquanto o espanhol é reservado para situações formais, como a escola e a administração pública. Quando o interlocutor é monolíngue em espanhol, os uruguaios da fronteira também interagem em espanhol. Há vários estudos de comunidades fronteiriças que detectaram esse padrão. Hensey (1972, p. 76-79) havia descrito esse padrão diglóssico, de escolha de línguas, e Elizaincín (1992, p. 92), 20 anos depois, constatou novamente que o espanhol é a língua da escola e dos meios oficiais de comunicação e o português é a língua do Brasil e dos contextos familiares no Uruguai fronteiriço.

No exemplo a seguir, continuo a conversa em português com a professora brasileira da escola uruguaia, interrompida por um telefonema.

Entrevistada: Mas eu acho que antes de ir pra Brasília, já tem toda a tabelinha que eles mesmos fazem ali né?

Pesquisadora: É porque é meio padronizado né.

Entrevistada: É. Eu acho que sim.

Pesquisadora: Eu não sabia que ele era aplicado no Uruguai (conversa o teste de proficiência em português Celpe-Bras).

Entrevistada: É, ele é até aplicado em muitos lugares. Em Argentina...

(Telefone toca com uma música brasileira) 


\section{Entrevistada: Hola, hummm}

(risos) No, no estoy comiendo.

Si, bárbaro, yo espero entonces.

Tá, muchas gracias.

Tá, gracias.

?Vino en la factura;

$\mathbf{T a ́}^{53}$, bueno, tchau, muchas gracias, tchau.

Eu pedi porque aqui é um atraso né. Preciso de, dos cartucho de impressora e eu pedi que me mandasse de Melo.... (agora, a entrevistada fala comigo).

No momento do telefonema, há uma mudança de interlocutor e de interação verbal, por isso a língua escolhida muda para o espanhol, porque o rapaz ao telefone também falava espanhol. Assim, o português só era utilizado para falar comigo na entrevista. Essa alternância completa de línguas é um fato de escolha de línguas (language choice), escolha entre dois sistemas.

Também é muito comum ocorrer a escolha de línguas no freeshop do lado do Uruguai em Aceguá, uma vez que os atendentes são todos uruguaios e falam espanhol e português, com suas respectivas interferências. Assim, é muito comum perguntar as coisas em português e eles responderem ora em português, ora em espanhol. Esses exemplos são recorrentes em situações fronteiriças e são prototípicos de uma sociedade bilíngue. Supostamente há fatores sociais para que esses vendedores mudem de idioma quando falam com clientes, tais como lugares, sexo, classe social, nacionalidade diferente.

Em suma, vimos que o português falado em ambos os lados da fronteira apresenta fenômenos prototípicos de situações de bilinguismo, como empréstimo lexical, code-switching e escolha de línguas. Também foram exemplificados fenômenos linguísticos variáveis comuns ao português brasileiro como um todo e ao português uruguaio da fronteira de Aceguá, tais como a alternância nós e a gente em contexto de primeira pessoa do plural, que é objeto de estudo deste trabalho.

Todos esses processos são típicos e produtivos quando há duas ou mais línguas em contato. Como a amostra é oriunda de uma região fronteiriça, é imprescindível ter uma visão de conjunto do que pode acontecer linguística e socialmente em uma variedade linguística que está em contato com outra.

No intuito de entender a origem dos pronomes e como funciona seu uso atualmente na língua, relatamos a seguir, brevemente, o percurso dos pronomes nós e a gente.

\footnotetext{
${ }^{53}$ A redução de "está" para "tá", como um marcador discursivo, é bastante comum tanto no português quanto no espanhol monolíngue de Montevidéu.
} 


\section{CAPÍTULO 3 - A DIACRONIA E A SINCRONIA DOS PRONOMES DE PRIMEIRA PESSOA DO PLURAL}

\author{
Poema a Jorge Amado \\ O cais... \\ O cais é um cais como muitos cais do mundo... \\ As estrelas também são iguais \\ as que se acendem nas noites baianas \\ de mistério e macumba. \\ (que importa, afinal, que as gentes sejam \\ moçambicanas \\ ou brasileiras, brancas ou pretas) \\ Jorge Amado, vem! \\ Aqui, nesta povoação africana \\ o povo é o mesmo também \\ é irmão do povo marinheiro da Bahia, \\ companheiro Jorge Amado, \\ amigo do povo, da justiça e da liberdade.
}

(Noémia de Sousa, 2001, p. 136-137)

\author{
Amor é fogo que arde sem se ver \\ Amor é fogo que arde sem se ver; \\ É ferida que dói e não se sente; \\ $E$ E um contentamento descontente; \\ É dor que desatina sem doer. \\ É um não querer mais que bem querer; \\ É um andar solitário entre a gente; \\ É nunca contentar-se de contente; \\ É um cuidar que se ganha em se perder. \\ É querer estar preso por vontade \\ É servir a quem vence o vencedor, \\ É ter com quem nos mata lealdade.
}

Mas como causar pode seu favor Nos corações humanos amizade; Se tão contrário a si é o mesmo amor?

(Luís de Camões, 2003, p. 70 )

A partir desses poemas, nota-se que o uso de "a(s) gente(s)" impessoal, com ou sem o traço de número, também foi registrado no português africano de Moçambique de Noémia de Sousa ${ }^{54}$, em 1949 (século XX), e no português europeu de Luis de Camões ${ }^{55}$, em 1595 (século XVI). Essa característica impessoal, ainda presente no espanhol, é um traço arcaico do português de maneira geral.

Em toda a obra Os Lusíadas, a gente ou as gentes são empregados como sintagmas de terceira pessoa, indefinidos. Na própria antologia do autor, segundo Segismundo \& Spina ${ }^{56}$, há uma referência ao emprego da expressão a gente com o mesmo valor do português contemporâneo, extensão de sentido que é de "o ser humano" (p. 31). Encontram-se exemplos no singular (p. 174) e no plural (p. 89) como:

\footnotetext{
${ }^{54}$ Carolina Noémia Abranches de Sousa Soares foi escritora moçambicana e escreveu esse poema, em 1949, em homenagem a Jorge Amado. O livro "Sangue Negro" foi reeditado em 2001, pela Associação dos Escritores Moçambicanos.

${ }^{55}$ Luis Vaz de Camões foi um importante escritor português e escreveu esse poema em 1595. O livro "Obra Completa" foi reeditado em 2003, pela Editora Nova Aguilar.

${ }^{56}$ Não foi encontrado o ano de publicação dessa antologia.
} 
Vedes agora a fraca geração

Quem dum vassalo meu o nome toma,

Com soberbo e altivo coração

A vós e a mi e o mundo todo doma.

Vedes, o vosso mar cortando vão,

Mais do que fez a gente alta de Roma;

Vedes, o vosso reino devassando,

Os vossos estatutos vão quebrando.

$[\ldots]$

Em tão longo caminho e duvidoso

Por perdidos as gentes nos julgavam.

É importante, pois, analisar o percurso histórico da expressão lexical a gente até sua gramaticalização em pronome, a partir da descrição diacrônica e sincrônica dos pronomes nós e a gente. Por isso, explicamos brevemente a origem do pronome a gente no latim e no português arcaico, comparamos a abordagem de nós e a gente das gramáticas tradicionais e das gramáticas descritivas, e explicamos sucintamente o funcionamento dos pronomes de primeira pessoa do plural atualmente no português brasileiro, no português uruguaio e no espanhol uruguaio, para que possamos entender melhor a complexidade desse fenômeno em termos de semelhanças e diferenças entre essas variedades linguísticas.

\subsection{Nós e a gente no latim, no português arcaico e em línguas românicas.}

$\mathrm{Na}$ época do latim vulgar, houve mudanças morfológicas na estrutura da língua com a criação de novos indefinidos, ou com a extensão do sentido já existente. Entre eles, segundo Ilari (2006, p. 96), “unus assume, além de seu papel de numeral, também as funções de pronome adjetivo/indefinido; com nec, forma nec unus ("nem um"), que substitui o antigo indefinido negativo, nullus." $\mathrm{O}$ autor também registra $\mathrm{o}$ desaparecimento de alguns termos da classe dos indefinidos, como omnis.

No espanhol, assim como em italiano, francês e inglês, ainda mantém-se o uso de "uno" como pronome indefinido, diferentemente do português, como nos exemplos, respectivamente:

Uno no debe juzgar tan rápidamente.

Uno non deve essere troppo rapido per giudicare

On ne doit pas être trop rapide pour juger

One shouldn't be too quick to judge

Não se deve julgar com tanta rapidez. 
Na gramática de Hermoso, Cuenot e Alfaro (2006, p. 62), o pronome "uno" é analisado como um dos pronomes indefinidos que "constituyen uma classe de palavras com valor de adjetivo, pronombre, o adverbio, que dan al nombre al que califican o sustituyen un valor indeterminado: cuantitativo, cualitativo o intensivo". Nesse caso, uno expressa quantidade ou intensidade.

No português brasileiro atual, o se que pode manter o significado de indeterminado nesses casos exemplificados. Mas, segundo um estudo de tradução do francês para o português, de Aguiar (2002, p. 87), não há um correspondente para on no português e, por isso, ora é traduzido como primeira pessoa do plural ora como terceira pessoa do plural. Assim, on pode designar uma ou várias pessoas determinadas no discurso.

No francês, o pronome indefinido on corresponde a "uma pessoa", "cada um" ou "se" e precede o verbo na $3^{\mathrm{a}}$ pessoa do singular: on dit (diz-se). Os indefinidos com sentido negativo requerem o advérbio de negação ne antes do verbo. Em línguas germânicas, como o alemão, o pronome indefinido deve ser traduzido por man, seguido também pelo verbo na terceira pessoa do singular: man sagt (diz-se) (Dicionário Multilíngüe, p. 367 e 427).

Já no português arcaico, de acordo com Lopes (2003), o vocábulo homem significava substantivo e pronome indefinido.

\footnotetext{
As línguas românicas herdaram o uso indeterminado de homem, presente já no baixo latim e atestado nas variantes: hombrelome (espanhol), uomo (italiano), homem/ome (português), omul (valaquio), om/hom (provençal) e on (francês): este último mantém até hoje esse valor. Em português, entretanto, a partir do século XVI, o vocábulo homem deixa de ser usado como pronome, interrompendo aparentemente o processo de gramaticalização do substantivo. Outro item lexical -- a forma a gente -parece começar a preencher esse espaço vazio deixado no sistema pronominal. (LOPES, 2003, p. 1)
}

Segundo Mattos e Silva (2006, p. 160), o pronominal homen, próprio ao período arcaico (com o mesmo sentido do on francês), frequentemente expressa a indeterminação do sujeito. Para Lopes (2003, p. 7), não houve a pronominalização completa do homo em português, diferentemente do on no francês.

- $\quad$ E portanto as homen cree por mais verdadeiras quanto el foi mais presente.

- $\quad$ Ca naquel logar so homen ouvir falar de pescado.

- De cincoenta anos adeante vai ja homen folgando e assegando e quedando das tentações. 
Ainda segundo Mattos e Silva (2006, p. 160), também é possível constatar um exemplo de alternância entre homen e a passiva sintética, ambos em contexto de indeterminação do sujeito.

- A quinta he Geometria que fala dos contos e das medidas per que homen pode saber as canteas e os espaços da terra; a sexta he a música que fala em como se devian mudar e mesurar as vozes.

Mattos e Silva (2006, p. 169-170), citando Dias (1959, p. 94), relata que o pronome utilizado, na época, era homem, com as alomorfias omê e ome. (H)omen, como sujeito indeterminado, é recorrente do período arcaico até o século XVI. Ainda assim, há resquícios desse uso atualmente no nordeste brasileiro.

Para Lopes (2003, p. 7), a pronominalização do homo latino não se efetivou como mudança linguística no português, como aconteceu com on no francês. Ainda assim, no período arcaico, houve coexistência de homem (e variantes) como nome e pronome indefinido.

Para Teyssier (2004, p. 83-84), a obra do dramaturgo Gil Vicente, representada de 1502 a 1536, documenta a constituição de uma língua clássica. O caso de homem com sentido indeterminado aparece em suas peças como arcaísmos característicos de certos personagens, particularmente de camponeses e mulheres do povo. Era a prova de que esses traços eram marcados ou estigmatizados pelo público da Corte.

Teyssier (2004, p. 82-83) confirma que essa indefinição era representada até então pela palavra "homem", com o mesmo sentido do on francês, que desapareceu na época da formação do português clássico, até o fim do século XVI. Assim, a mudança linguística de "homem" não foi implementada e finalizada no português, pois o item lexical a gente, como indefinido ou genérico, primeiramente, entrou na língua para ocupar a lacuna pronominal do sistema linguístico desde a evolução do latim, uma vez que $a$ gente passou a indicar neutralidade.

Por isso, o processo de gramatizaliação de "homem" foi interrompido no século XVI. Nessa mesma época, os traços de número começam a desaparecer do nome (a) gente, o que pode ter interferido na pronominalização de homo uma vez que a gente tornou-se forte concorrente para substituir a vaga deixada pelo homem indefinido. " $\mathrm{O}$ emprego de homem, no português arcaico, está diretamente relacionado com a perda da referência do nome que, ao ser utilizado como pronome, pode admitir uma leitura impessoal (referência zero)" (LOPES, 2003, p. 8). A perda da referência também é sinal 
de que a expressão estava deixando a classe dos nomes, uma vez que a propriedade semântica é inerente aos nomes (LOPES, 2003, p.7).

Assim, a emergência de a gente se gramaticalizando é um novo processo depois da variação homem home. Primeiro a referencia é indefinida com sentido original de povo, depois torna-se genérica (ZILLES, 2007, p. 31).

A partir do século XVI, a ausência de traço plural para o substantivo gente, que perde propriedades nominais, ultrapassa $70 \%$. A pronominalização do substantivo gente foi um processo lento e gradual, que passa da referência indeterminada, determinada até chegar ao contexto mais específico, que é a referência a "eu".

Há registros de a gente como pronome já no século XVIII. Anteriormente partiu de uma expressão substativada para ambiguidade interpretativa entre sinônimo de pessoas ou de nós desde o século XVI, época em que o substantivo começa a perder suas propriedades de número. Mas é no século XIX que a ambiguidade deixa de existir e a gente passa a ser usado apenas como pronome no singular, dando início à fase da gramaticalização (LOPES, 2003, p. 4-6).

Séc. XVI:

Quanto mais se chega a fim do mundo, a todo andar, tanto a gente é mais ruim!

Séc. XVII:

(...) $\mathrm{E}$ os tigres, em tanta cantidade (por não haver descampados), que, em se metendo a rês no mato, não sae, e o mesmo risco corre a gente, se não anda acompanhada, e pelos rios e lagos dos jaguarés...

Séc. XIX:

Rosinha - A prima Maricota disse-me que era uma coisa de pôr a gente de queixo caído.

Para Lopes (2003, p. 6), essas ocorrências ficaram frequentes a partir do século XVI, pois eram mínimas no português arcaico. O sentido de a gente passou a incluir todas as pessoas, inclusive o pronome de primeira pessoa do singular "eu".

No período arcaico, coexistia o emprego de homem (e variantes) como nome e como pronome indefinido. Com o desparecimento de homem como pronome indefinido, o substantivo gente emerge como pronome. Assim, o processo de gramaticalização de itens lexicais passa por três usos funcionais, tais como substantivo, "interpretação ambígua" e pronome indefinido (LOPES, 2003, p. 7, 8).

Exemplo de a gente como substantivo

No que o moço cantava | o judeu meteu mentes, e levó-o a ssa casa,| poi se foram as gentes (p. 4). 
Exemplo de interpretação ambígua (pode ser substantivo ou pronome indefinido)

Rosinha - A prima Maricota disse-me que era uma coisa de pôr a gente de queixo caído. (p. 5)

Vianna (2012, p. 95 e 102), que analisou a alternância pronominal nós e a gente no português europeu, afirma que, diferentemente do português brasileiro, ainda há atualmente exemplos ambíguos no português europeu, nos quais não se pode afirmar se o próprio falante se inclui ou se são somente as outras pessoas.

\begin{abstract}
as coisas para nós são mais complicadas... muito mais complicadas...nós tamos muito mais...a gente da hotelaria nunca se ganhou tanto ou tão pouco não é tanto tanto pó mais é pó menos... nunca se ganhou tão pouco como agora... (Amostra Cacém: dado 580, MB1)

tá muito melhor agora porque naquele tempe para se vir ao Funchal gastavase três horas... hoje em dia onde eu faço em meia hora de tempo _ para vir a gente ao Funchal era a quase d'ano a ano ou quande se... (Amostra Funchal: dado 309, FC1)
\end{abstract}

Em nosso corpus, foram encontrados 10 dados de a gente com sentido de terceira pessoa ou até mesmo ambíguo no português uruguaio de Aceguá e três dados no português brasileiro de Aceguá, como se ainda fosse um vestígio histórico dessa expressão:

Isso aqui, a cultura é mais ou menos a mesma, de toda A GENTE se confunde.

( $\mathrm{ALE}^{57}$, homem, acima de 50 anos, uruguaio, ensino médio)

HIL: não, é lindo, A GENTE aqui toda, a vizinhança é boa.

(HIL, mulher, acima de 50 anos, brasileira, ensino médio)

Eu não gosto porque eu acho, uma coisa que, não gosto de tanta gente ali esperando um piquete ali, esperando um prato de comida, fazendo... eu vou, se há alguma pita eu logo vou e volto pra trás. Não sou de passar ali, e passar horas. Não gosto de estar dependiendo de ver A GENTE FAZENDO, cola DIZEMO no, a que hora se me escapo, você, como dise. Estoy esperando sim. Como se dizem lá, quando tu tá num banco, como é?

(CAR, homem, acima de 50 anos, uruguaio, ensino médio)

Nos dois primeiros exemplos, a referência parece ser mesmo à terceira pessoa, inclusive pelo quantitativo "toda" concordando em gênero e número. Já no terceiro caso, há maior ambiguidade porque não se sabe ao certo se o falante se inclui juntamente com as pessoas que fazem fila para comer nos piquetes em dias de Semana Farroupilha.

\footnotetext{
${ }^{57}$ Para manter o sigilo dos entrevistados, utilizamos apenas as três iniciais de um nome fictício em cada exemplo.
} 
A ambiguidade entre nomes e pronomes tem semelhanças porque também exercem mesma função sintática. A diferença é que os pronomes não podem ser antecedidos de determinantes e funcionam isoladamente como núcleo do sujeito. A própria ausência de determinante significa mais indeterminação (LOPES, 2003, p. 9). A referência genérica e a posição isolada foram condicionantes linguísticos semelhantes para homem e a gente, já que, "na pronominalização dos nomes, o item lexical passa a ocupar posições gramaticais mais fixas, tipicamente pronominais, podendo assumir um caráter mais genérico e indeterminado" (LOPES, 2003, p. 11).

Também com sentido impessoal, a expressão toda a gente era variante da expressão todo mundo. Esse uso era visto como brasileirismo pertencente ao português do Brasil, de acordo com Teyssier (2004, p. 106).

No espanhol, a expressão "la(s) gente (s)" permanece com o mesmo sentido de "todo mundo" ou "todas as pessoas" da época do português arcaico. Já no português brasileiro e uruguaio, atualmente, prevalece o uso de a gente como primeira pessoa do plural, tanto em contextos de referência genérica quanto em contextos mais específicos, ou como primeira pessoa do singular, em um contexto máximo de especificidade.

A forma la gente ou a gente tem a mesma origem latina (gens, gentis) no português e no espanhol. O percurso diferente é que no português, após o processo gramaticalização, o pronome a gente passou a designar algo indeterminado e genérico. No espanhol, a correspondência de la gente seria ellos (MAIA, 2008, p. 2659-2660).

Maia (2008, p. 2664-2665) aponta alguns fatos curiosos sobre o uso de "la gente", num estudo diacrônico desde o século XII até o período contemporâneo: (i) "la gente" também está se especializando na posição pronominal, ou seja, antes do verbo (posições mais fixas); (ii) há muita ocorrência de "la gente" com determinação de "toda"; (iii) a forma singular está ocorrendo com mais frequência; (iv) "la gente" não aceita mais outro termo no meio da expressão, como "la vil gente". Assim, a forma la gente parece estar, portanto, se gramaticalizando como forma pronominal de indeterminação, visto que os ambientes favoráveis a essa gramaticalização são os de referência indefinida.

A expressão lexical plena a gente, ao longo do tempo, passou a equivaler a nós, tanto no português brasileiro quanto no português uruguaio. De acordo com Faraco (2005, p. 39-40), esse tipo de mudança linguística é conhecido como gramaticalização, ou seja, é quando um elemento lexical (uma palavra) ou uma expressão lexical plena se transforma em um elemento gramatical, como pronome ou preposição. 
Até então, não havia registros de a gente como primeira pessoa do plural na fronteira, justamente porque la gente no espanhol tem uma conotação mais indefinida e de terceira pessoa do plural. Nosso trabalho demonstra, pois, que o a gente no português uruguaio (falado por uruguaios bilíngues) da fronteira também está no mesmo processo de gramaticalização que no português brasileiro como um todo. A diferença maior deve ser de frequência, uma vez que parece ser mais recente no português uruguaio.

\subsection{Nós e a gente nas gramáticas tradicionais}

A variação pronominal de primeira pessoa do plural, como a maioria dos fenômenos linguísticos variáveis, não é devidamente registrada nas gramáticas tradicionais. Algumas delas sequer registram o uso, e outras registram o pronome ainda com certa cautela.

Cunha e Cintra (2004, p. 166) já citam o pronome a gente, mas associando seu uso aos contextos de informalidade.

\footnotetext{
O substantivo gente, precedido do artigo a e em referência a um grupo de pessoas em que se inclui a que fala, ou a esta sozinha, passa a pronome e se emprega fora da linguagem cerimoniosa. Em ambos os casos o verbo fica na $3^{\mathrm{a}}$ pessoa do singular.
}

A linguagem cerimoniosa é, certamente, a linguagem mais formal. O que o gramático não percebe é que o uso de a gente extrapola os contextos orais e mais informais, chegando até mesmo a contextos mais monitorados e formais como se pode observar na fala e em produções textuais de alunos desde o nível fundamental (BRUSTOLIN, 2010) até o nível superior (SANTOS, COSTA e SILVA, 2011), além de vários outros tipos de manifestação linguística. Também há exemplos midiáticos, como o caso notório da própria chamada da Rede Globo "A gente se liga na Globo" ou "A gente se liga em você". Na escrita, o aparecimento de a gente está mais vinculado ao gênero textual, como o da propaganda, que mais se aproxima do interlocutor.

Assim, segundo Zilles (2007, p. 39-41), a gente parece não ser estigmatizado porque tem uma frequência alta de uso no Brasil (até 80\%), pode ser identificado em práticas sociais ligadas a determinados gêneros textuais, como literatura infantil, na voz de crianças, textos publicitários, correspondência comercial, dicionários, e, geralmente, não tem influência da escolaridade. 
Em outra gramática tradicional, a de Bechara (2001), o pronome a gente aparece como uma fórmula de representação da $1^{\text {a }}$ pessoa. O gramático restringe seu uso aos contextos coloquiais, tanto na variação com nós como na substituição por eu (BECHARA, 2001, p. 296). Essa expressão pronominal também é interpretada como equivalente a "eu" (Se a gente ganhar a luta, tudo na minha vida será diferente - disse o pugilista) em Faraco e Moura (2002, p. 287).

O uso de $a$ gente com sentido de "eu" também é registrado a analisado nos dados de Aceguá, dos dois lados da fronteira:

Entrevistadora: Lá é integral, como é que é que funciona?

Entrevistado: Eu entrava oito da manhã e saía às quatro da tarde. A GENTE almoçava lá.

(VAL, mulher, 15 a 30 anos, uruguaia, ensino médio)

Percebe-se, pois, que o pronome a gente não significa uma coletividade, mas sim a própria falante. São as pistas contextuais (o pronome "eu" anteposto) que nos ajudam nessa interpretação do pronome levando-se em consideração as marcas no contexto.

Ainda em Faraco e Moura (2002, p. 287), o a gente também aparece como impessoal ou indeterminado (Eu sabia os riscos que estava correndo. A gente sempre pensa: comigo não vai acontecer. Aí aconteceu, diz.). No entanto, ao analisar o contexto discursivo, nota-se também nesse dado que a gente está em um contexto de primeira pessoa do singular, com a presença do pronome pessoal reto "eu sabia" e do pronome pessoal oblíquo "comigo".

Em Almeida (1990, p. 172), há apenas uma breve menção ao pronome a gente como pertencente ao grupo dos pronomes de tratamento, ou seja, aqueles que substituem a terceira pessoa gramatical. Assim, nota-se que o gramático não considera o uso de a gente como primeira pessoa do plural, mas apenas o uso indeterminado.

Como as gramáticas tradicionais prescrevem normas, e não descrevem propriamente a língua falada, é preciso buscar gramáticas descritivas e pesquisas linguísticas que expliquem melhor como funcionam os pronomes de primeira pessoa do plural no português brasileiro, sobretudo o pronome gramaticalizado a gente. 


\subsection{Nós e a gente nas gramáticas descritivas e na gramaticalização}

Nessa nova era de gramáticos linguistas, selecionamos dois autores, Neves (2000, 2008, 2009) e Castilho (2010), para ilustrar como o fenômeno nós e a gente é analisado do ponto de vista da gramática descritiva, que, em sua maioria, tem como base a realidade linguística do português culto brasileiro ${ }^{58}$ e o processo de gramaticalização.

Da mesma forma que nós, a expressão a gente também pode se referir ao indivíduo que fala ( gente=eu) (NEVES, 2008, p. 529). Segundo Neves (2008, p. 509, 521), a propriedade geral dos pronomes pessoais é serem palavras (i) fóricas - quando assumem referência no uso, retomando passagens do texto ou apontando traços específicos de fala; e (ii) exofóricas ou dêiticas - quando é preciso recorrer à situação extralinguística, de quem é a fala e para quem a fala está sendo dirigida. As duas grandes funções são interacional e textual.

Neves (2009, p. 39-40) explica a variação pronominal de primeira pessoa do plural a partir da gramaticalização, que é um processo da mudança linguística, ou seja, um processo em andamento. Para isso, utiliza exemplos diferentes do uso de a gente:

- O primeiro, historicamente "legítimo",59

Diligente e decidida é quase toda a gente desta região, mas também é um tanto intolerante, ainda pouco civilizada.

- O segundo, hoje, "tolerável” na linguagem coloquial

Bem, a gente depois combina.

\footnotetext{
${ }^{58}$ Lucchesi (1994, p. 18-26) propõe três conceitos de norma: norma padrão, norma culta e norma popular. A norma padrão é a norma ideal, sem falantes, prescrita pela gramática tradicional. A norma culta é de fato a língua utilizada pelos falantes cultos de nível superior completo e antecedentes biográfico-culturais urbanos dos segmentos mais favorecidos da sociedade. A norma vernácula seria a língua falada pelas classes dominadas, estigmatizadas e não escolarizadas. Bagno (2005 e 2003) faz uma releitura desssa e de outras terminologias em sua tese de doutorado, publicada como livro em "Dramática da Língua Portuguesa" (2005), a partir de uma longa resenha de textos que tratam desse tema. Para Bagno (2005, p. 141-156) e (2003, p. 51-70), a divisão seria entre norma padrão (que não é variedade linguística e, portanto, não é falada por ninguém), variedades cultas e variedades populares e, posteriormente, variedades prestigiadas e estigmatizadas, que refletem mais as características sociolinguísticas de uma comunidade.

59 As aspas são da própria autora talvez pelo fato de as expressões serem até pejorativas no caso de "tolerável".
} 
- E o terceiro, ainda "proscrito"

Eu disse: a gente podemos enforcar, que isso não vale nada.

É perceptível que a expressão lexical a gente originalmente significasse uma terceira pessoa e a referência fosse totalmente indeterminada. Posteriormente houve uma mudança linguística em que a gente transformou-se em pronome de primeira pessoa do plural, ainda não totalmente gramaticalizado, principalmente se levarmos em consideração que a expressão "a gente podemos" é estratificada socialmente no português brasileiro e, portanto, não é um traço gradual das variedades linguísticas do Brasil. Esse caso é mais estigmatizado e menos recorrente no português brasileiro do que no português europeu.

A terminologia traços graduais e traços descontínuos é de Bortoni (1998, p. 102), que caracteriza, em verdade, dois tipos de regras variáveis; regras descontínuas "que definem uma estratificação descontínua" e regras graduais "que definem uma estratificação contínua". Os traços graduais são exemplificados pelo uso de a gente juntamente com a concordância padrão (a gente vai), e os traços descontínuos são exemplificados pelas expressões a gente vamos e nós vai, já que há estigma por parte do falante e é resultado de uma estratificação social maior. Em suma, traço gradual indica um uso mais geral e uma menor estratificação, e o traço descontínuo indica uma maior estratificação e um uso mais específico por alguns grupos de falantes ou membros da comunidade.

Voltando ao percurso diacrônico de a gente, é importante entender alguns princípios da gramaticalização, propostos por Neves (2009, p. 39-40):

- Persistência - na ocorrência tolerável, "permanecem vestígios de significado lexical original" de terceira pessoa com sentido genérico.

- Descategorização - "perda ou neutralidade dos marcadores morfológicos e das características sintáticas próprias das categorias plenas (como os substantivos)". A variação morfológica desconsidera "o estatuto de terceira pessoa de a gente (um sintagma nominal): trata-se de uma flexão, para efeito de concordância, em primeira pessoa do plural, concordância necessariamente ligada a uma categoria pronominal, não substantiva". Acredito que nessa categoria se enquadre o exemplo a gente vamos que 
passa a concordar também com a primeira pessoa do plural, e não somente com a terceira do singular.

- Divergência e estratificação - "coexistência dos dois diferentes modos de concordância com a forma quase-pronominal a gente - uma na terceira pessoa do singular e outra na primeira pessoa do plural - e, ao mesmo tempo, mantém-se vivo o uso original do sintagma nominal a gente."

- Especialização - diferentes níveis de funcionalidade e de valorização sociocultural para cada realização linguística. São diferentes escolhas para diferentes fins.

Nesse sentido, mesmo com a expansão do uso de a gente no português brasileiro, há algumas posições em que o pronome não ocorre, como a possibilidade de definir a cardinalidade (quantos indivíduos) para nós, diferentemente de a gente. (Ex: Todos nós. *Todos a gente. (NEVES, 2008, p. 517-518). A nosso ver, a agramaticalidade do exemplo *Todos a gente é uma evidência de que o pronome $a$ gente ainda não está totalmente gramaticalizado no português brasileiro, como os exemplos "nós quatro" e "*a gente quatro".

Com relação aos possessivos no sintagma nominal (SN), também é possível a combinação de o ou um como demonstrativo juntamente com o possessivo. Ex: Esse nosso cineminha/Agora vamos para o nosso outro assunto (NEVES, 2008, p. 577 e 579). Novamente o possessivo correspondente ao pronome a gente (da gente) não ocorre em contexto de sintagma nominal com artigos $o$ ou um, ou seja, o pronome $a$ gente ainda não está completamente implementado, mas em processo de gramaticalização no português brasileiro, seguindo todos os cinco princípios descritos por Neves (2008).

Zilles (2007, p. 32-33) também trata da gramaticalização com uma mudança linguística em que se atribui o status gramatical a um item lexical, mas subdivide os princípios em quatro, a saber:

- Dessemantização: redução semântica, bleaching, perda de conteúdo semântico. A gente perde o traço de povo, porém mantém o de pessoa. 
- Extensão: generalização contextual, uso em novos contextos; Quando se percebe o uso de a gente na função de sujeito aumentar de 1970 para 1990 e expandir para contextos além do genérico, como a referência mais específica. Seria o equivalente à persistência de Neves (2008, p. 39-40).

- Descategorização: perda de propriedades morfossintáticas características das formas-fonte, incluindo a perda do status de palavra independente própria da cliticização e da afixação. Quando "gente" está em estruturas fixas como "boa gente", e perde o plural gramatical e o gênero feminino ao longo do tempo. Seria o equivalente à descategorização de Neves (2008, p. $39-40)$

- Erosão: redução fonética, perda de substância fonética. Quando a gente adquire novas pronúncias como: A gente, a hente, a'ente, 'ente.

Nesse sentido, para Zilles (2007, p. 28-29, 34), o feixe de mudanças está interrelacionado com o sistema pronominal e com a concordância dos pronomes nós e a gente, e você e tu. Assim, a inserção de a gente e você no português brasileiro atinge o parâmetro do sujeito preenchido, que tem se tornado frequente como resultado da redução do paradigma verbal. Há também o impacto da redução fonética de você para cê da mesma forma que de a gente para a hente, a'ente, 'ente.

Além de Neves (2008), Castilho (2010, p. 207 e 439) também descreve esse fenômeno linguístico em sua gramática e afirma que há substituição de nós por a gente tanto no português brasileiro popular como no português brasileiro culto. Mais adiante (2010, p. 477) ressalta que a gente comuta com nós nos mesmos contextos. E na página seguinte (2010, p. 478), de fato, traz os dados da pesquisa de Omena (1978) para delimitar as variáveis propícias para o uso de a gente.

Dessa forma, Castilho (2010, p. 477) fornece resultados variacionistas que contribuem para a discussão de que não se trata de uma mera substituição de uma forma por outra, mas sim de variação linguística condicionada por fatores linguísticos e sociais. Assim, a expressão a gente aparece junto com os outros pronomes pessoais numa reconfiguração do quadro pronominal brasileiro, ainda que seja registrada apenas como pertencente ao português brasileiro informal quando já se sabe que o a gente também exista no português mais formal. 
A partir dessa concepção de variação linguística, sintetizamos a seguir pesquisas variacionistas no âmbito do português brasileiro e do português europeu sobre a alternância nós e a gente como pronome de primeira pessoa do plural.

\subsection{Nós e a gente no português brasileiro e no português europeu}

Desde a década de 1980, inúmeros estudos variacionistas têm sido realizados sobre a variação pronominal de primeira pessoa do plural na variedade do português brasileiro. Por isso, faz-se necessário reunir alguns trabalhos para identificarmos a frequência em cada localidade e em cada região do Brasil, que servirá para compararmos com os resultados do português brasileiro da fronteira e do português uruguaio.

No português uruguaio, não se tem estudos variacionistas acerca desse fenômeno linguístico. No português europeu, os estudos são poucos (RUBIO, 2012 e VIANNA, 2011), se comparados ao português brasileiro, mas já revelam que, em Portugal, a tendência maior é o uso do pronome nós (RUBIO, 2012, p.355); o a gente é utilizado com concordância no plural em 1/4 das ocorrências (RUBIO, 2012, p. 18); o PE tem comportamento mais conservador e a variação é estável com mudança geracional enquanto no PB o comportamento é mais inovador e a mudança está em curso (VIANNA, 2011, p. 202-204 e RUBIO, 2012, p. 356); a faixa etária não é selecionada no PE, mas a frequência de uso de nós é maior entre os jovens, enquanto no PB a faixa etária é selecionada com os jovens favorecendo mais a gente (RUBIO, 2012, p. 358).

Para analisarmos as diferenças e semelhanças da variação de primeira pessoa do plural no Brasil e em Portugal, é interessante comparar, minimamente, as frequências de nós e a gente no português brasileiro como um todo e no português europeu conforme a Tabela 1. 
Tabela 1: Percentagem global das variantes nós e a gente no português brasileiro e no português europeu.

\begin{tabular}{|c|c|c|c|}
\hline VARIEDADE & AUTOR & A GENTE & NÓS \\
\hline $\begin{array}{l}\text { Caimbongo - Cachoeira - C. rural afro- } \\
\text { brasileira - BA }\end{array}$ & Oliveira, 2008 & $85 \%$ & $15 \%$ \\
\hline João Pessoa - Projeto VALPB ${ }^{60}-$ PB & Fernandes, 1999 & $79 \%$ & $21 \%$ \\
\hline $\begin{array}{l}\text { Rio de Janeiro - Amostra Censo de } 2000 \\
\text { - RJ }\end{array}$ & Omena, 2003 & $79 \%$ & $21 \%$ \\
\hline $\begin{array}{l}\text { Rio de Janeiro - Amostra Censo de } 1986 \\
\text { - RJ }\end{array}$ & Omena, 2003 & $78 \%$ & $22 \%$ \\
\hline Pelotas - Projeto VARX ${ }^{61}-$ RS & Borges, 2004 & $78 \%$ & $22 \%$ \\
\hline Goiás - GO & Mattos, 2013 & $77 \%$ & $23 \%$ \\
\hline Norte fluminense $-\mathbf{R J}$ & Machado, 1995 & $73 \%$ & $27 \%$ \\
\hline Interior Paulista Iboruna - SP & Rubio, 2012 & $73,8 \%$ & $26,2 \%$ \\
\hline Florianópolis - Projeto VARSUL ${ }^{62}-\mathrm{SC}$ & Seara, 2000 & $72 \%$ & $28 \%$ \\
\hline Vitória - Projeto PORTVIX ${ }^{63}-$ ES & Mendonça, 2010 & $70,8 \%$ & $27,3 \%$ \\
\hline Rio de Janeiro - RJ & Omena; Braga, 1996 & $70 \%$ & $30 \%$ \\
\hline Jaguarão - Projeto BDS Pampa ${ }^{64}-$ RS & Borges, 2004 & $69 \%$ & $31 \%$ \\
\hline Porto Alegre - RS & Zilles, 2007 & $69 \%$ & $31 \%$ \\
\hline Curitiba - PR & Borba, 1993 & $64 \%$ & $36 \%$ \\
\hline NURC - RJ & Silva, 2010 & $63 \%$ & $37 \%$ \\
\hline $\begin{array}{l}\text { Piabas - C. rural de Anselino da Fonseca } \\
\text { - BA }\end{array}$ & $\begin{array}{l}\text { Sampaio e Lopes, } \\
2009\end{array}$ & $62 \%$ & $38 \%$ \\
\hline Blumenau - SC & Tamanine, 2002 & $60 \%$ & $40 \%$ \\
\hline Rio de Janeiro - Projeto NURC ${ }^{65}$ & Lopes, 1998 & $59 \%$ & $61 \%$ \\
\hline Lages - SC & Tamanine, 2002 & $58 \%$ & $42 \%$ \\
\hline $\begin{array}{l}\text { Cinzento - C. afro-brasileira - Projeto } \\
\text { Vertentes }^{66}-\text { BA }\end{array}$ & $\begin{array}{l}\text { Antonino; Bandeira, } \\
2011\end{array}$ & $56 \%$ & $44 \%$ \\
\hline Brasilândia - C. de Periferia - SP & Coelho, 2006 & $53 \%$ & $47 \%$ \\
\hline Blumenau - SC $^{67}$ & Silva, 2004 & $51 \%$ & $49 \%$ \\
\hline Concordia - SC & Franceschini, 2011 & $50 \%$ & $50 \%$ \\
\hline Chapecó - SC & Tamanine, 2002 & $48 \%$ & $52 \%$ \\
\hline $\begin{array}{l}\text { Rio de Janeiro, Porto Alegre e Salvador } \\
\text { - Projeto NURC }\end{array}$ & Lopes, 1998 & $42.2 \%$ & $57.8 \%$ \\
\hline CRPC $^{69}-$ Portugal & Rubio, 2012 & $42 \%$ & $58 \%$ \\
\hline Ponta Porã - C. de Assentados - MS & Muniz, 2008 & $39 \%$ & $61 \%$ \\
\hline Salvador - Projeto NURC & Lopes, 1998 & $37 \%$ & $63 \%$ \\
\hline Porto Alegre - Projeto NURC & Lopes, 1998 & $28 \%$ & $72 \%$ \\
\hline Funchal - Portugal & Vianna, 2011 & $26 \%$ & $74 \%$ \\
\hline Cacém - Portugal & Vianna, 2011 & $22 \%$ & $78 \%$ \\
\hline Oeiras - Portugal & Vianna, 2011 & $9 \%$ & $91 \%$ \\
\hline
\end{tabular}

\footnotetext{
${ }^{60}$ Projeto VALPB - Variação Linguística no Estado da Paraíba.

${ }^{61}$ Projeto VARX - Banco de dados por classe social de Pelotas.

${ }^{62}$ Projeto VARSUL - Variação Linguística na Região Sul do Brasil.

${ }^{63}$ Projeto PORTVIX - Português Falado na Cidade de Vitória.

${ }^{64}$ Projeto BDS Pampa - Banco de dados sociolinguísticos.

${ }^{65}$ Projeto NURC - Norma Urbana Oral Culta do Rio de Janeiro.

${ }^{66}$ Projeto Vertentes - Português Popular do Estado da Bahia.

${ }^{67}$ As entrevistas foram feitas com profissionais da saúde, em sua grande maioria, graduados, e obtidas por meio de entrevistas do Programa do Jô.

${ }^{68}$ Projeto NURC - Norma Urbana Oral Culta do Rio de Janeiro. Esses são os resultados das três localidades juntas.

${ }^{69}$ CRPC - Corpus de Referência do Português Contemporâneo.
} 
Em termos de frequência geral do fenômeno, de $59 \%$ a $85 \%$, os estados que mais utilizam o pronome a gente são: Bahia (comunidade isolada), Paraíba, Rio Grande do Sul (Pelotas), Goiás, São Paulo (interior), Santa Catarina (Florianópolis) Espírito Santo, Rio de Janeiro (de 59\% a 78\%). De 58\% a 69\%, os estados são: Rio Grande do Sul (Jaguarão, Porto Alegre) e Santa Catarina (Curitiba, Blumenau, Lages) e a comunidade rural de Piabas (Bahia). De $48 \%$ a 56\%, os estados são: comunidade afrobrasileira (Bahia), São Paulo (periferia), Santa Catarina (Blumenau, Concórdia e Chapecó). Abaixo de $42 \%$ de uso de a gente, ou seja, favorecendo o uso de nós, temos: o trabalho de Lopes (1998) que mostra resultados conjuntos para Rio de Janeiro, Porto Alegre e Salvador (Projeto NURC). Em amostras separadas do português culto, Porto Alegre (28\%) e Salvador (37\%) permanecem com percentuais baixos. Em outras amostras do RJ, registra-se que a frequência de uso do a gente chega no mínimo a 59\% (para essa amostra do NURC, ou seja, apenas de falantes cultos), 63\%, 70\%, 73\%, 78\% e no máximo de 79\%, enquanto em Porto Alegre é bem mais alta com $69 \%$ quando não se trata somente de falantes cultos.

O Brasil é um país continental e, justamente por conta da sua grandeza, os estados de uma mesma região não exibem um comportamento linguístico idêntico, haja vista que o uso de a gente no Rio Grande do Sul, por exemplo, ocorre desde $78 \%$ (Pelotas) até 69\% (Jaguarão e Porto Alegre); no Paraná é de 64\% (Curitiba); e em Santa Catarina, por sua vez, a frequência é de $72 \%$ (Florianópolis), 60\% (Blumenau), 58\% (Lages) até $48 \%$ (Chapecó). De uma forma geral, o português brasileiro privilegia o uso de a gente em detrimento de nós, exceto em Chapecó (SC). Até mesmo em comunidades mais isoladas $(53 \%, 56 \%, 62 \%$ e $85 \%)$ o a gente já está presente majoritariamente, exceto em Ponta Porã (39\%), talvez pela situação fronteiriça com o Paraguai, ainda que não tenha acidente geográfico.

Interessante também observarmos os resultados de Jaguarão (Brasil) que faz fronteira ao Sul com Rio Branco (Uruguai). Nessa localidade, o uso de a gente é de $69 \%$ contra $31 \%$ do uso de nós. Jaguarão é uma fronteira com acidente geográfico, ou seja, seu limite é estabelecido fisicamente por meio de uma ponte. Essa comunidade fronteiriça exibe resultados semelhantes à maioria do Brasil quanto ao uso crescente do pronome a gente.

Entre os grupos de fatores sociais que normalmente são relevantes para o fenômeno, podem-se citar, em ordem de recorrência: (v) faixa etária, (vi) sexo; (vii) escolaridade; e (viii) localidade. Entre os grupos de fatores linguísticos, praticamente 
em todos os trabalhos, podem-se elencar, em ordem de importância: (i) paralelismo formal e discursivo; (ii) traço semântico do referente ou tipo de referência; (iii) tempo verbal; e (iv) saliência fônica.

Sobre o português europeu, Vianna (2011), na análise da alternância pronominal de três cidades de Portugal, obteve valores diferentes para cada uma das comunidades $(26 \%, 22 \%$ e $9 \%$ de uso do a gente, respectivamente, para Funchal, Cacém e Oeiras). Assim, Vianna (2011, p. 90) conclui que

\begin{abstract}
a forma inovadora 'a gente' é a estratégia preferencial no desempenho oral dos entrevistados brasileiros; ao passo que, entre os portugueses que compõem a amostra, é a forma padrão 'nós' que se destaca como a mais produtiva na indicação da primeira pessoa do plural.
\end{abstract}

Em termos de comparação dos trabalhos sobre português europeu, os percentuais de Vianna (2011) e Rubio (2012) são bem diferentes. As três comunidades do português europeu obtiveram 74\%, 78\% e $91 \%$ de uso do nós, respectivamente, para Funchal, Cacém e Oeiras. Os resultados de Rubio (2012) são de 58\% para o uso de nós.

A diferença dos dois trabalhos reside nas diferentes opções metodológicas escolhidas que interferem, sobretudo, nos resultados percentuais. Rubio (2012) considera apenas os casos de sujeito explícito e sujeito não-explícito que apresentam em contextos anteriores as formas nós e a gente. O emprego de -mos sem referente explícito não é considerado dado, tanto nos casos isolados como nas primeiras referências, pois não é possível saber se o sujeito nulo é nós ou a gente, porque "no PE, tanto a forma nós como a gente são candidatas potenciais a ocorrer com verbos flexionados em 1PP”.

No entanto, Vianna (2011) considera esses dados, o que altera seu resultado geral com a frequência alta do pronome nós. Assim, os resultados de Vianna (2011) para o pronome nós estão vinculados às ocorrências de verbos com desinências de 1PP sem referente explícito, ou seja, os casos de zero nós. Nesse sentido, a proposta da pesquisa de Rubio (2012) tem como um dos focos a análise da alternância pronominal entre nós e a gente, e não a representação do sujeito em 1PP do discurso (RUBIO, 2012, p. 227-230).

Neste trabalho, assim como em Vianna (2011), consideramos todos os dados de sujeito implícito com a desinência de primeira pessoa do plural como sendo nós, porque não há nenhum dado de sujeito explícito com o pronome a gente e desinência -mos nas 
entrevistas de Aceguá, fato que confirma o uso menos encaixado na fronteira. Nesse sentido, toda vez que aparece essa desinência e o sujeito implícito/não expresso, consideramos que se trata do pronome nós, assim como Vianna (2011).

Rubio (2012) afirma que tanto no português brasileiro quanto no português europeu há variação pronominal de primeira pessoa do plural e de concordância verbal de primeira pessoa do plural. No português europeu, a frequência de uso do pronome $a$ gente é de $42 \%$, enquanto no português brasileiro do interior paulista é de $73.8 \%$. No português brasileiro, quatro variáveis linguísticas (paralelismo discursivo, saliência fônica, grau de determinação do sujeito e tempo e modo verbal) e duas extralinguísticas (escolaridade e faixa etária) foram selecionadas. No português europeu, uma variável linguística (paralelismo discursivo) e duas extralinguísticas (escolaridade e sexo) foram selecionadas. A faixa etária não foi selecionada para o português europeu, mas a frequência mostra que quanto maior a idade, maior o uso de $a$ gente.

Para Rubio (2012, p. 357) "o fenômeno variável se sujeita às mesmas "pressões” formais, ainda que os pronomes exerçam funções diferentes em cada uma das variedades", porque paralelismo discursivo é semelhante nas duas variedades, e também em Aceguá, como teremos oportunidade de ver, mas traço semântico do sujeito e tempo e modo verbal são diferentes. Deve-se levar em conta também que a produtividade de $a$ gente é menor em Portugal e no Uruguai do que no Brasil.

Uma diferença importante, segundo Rubio, é que, no português europeu, o pronome a gente é estigmatizado, por isso as mulheres e os mais escolarizados tendem a evitar seu uso. No português brasileiro e no português uruguaio de Aceguá, o pronome a gente é inovador, mais urbano e mais prestigiado. Essa provável ausência de estigma, segundo Zilles (2007, p. 37), se justifica pelo caráter crescente do uso da forma inovadora a gente na fala de todo o país, o que chega a quase $80 \%$.

$\mathrm{Na}$ variedade portuguesa, a concordância verbal com nós é categórica, mas com a gente é variável. A frequência da concordância verbal de primeira pessoa do plural fica em torno de $24,5 \%$ para a gente vamos e $75,5 \%$ para a gente vai, percentuais mais altos que no português brasileiro (RUBIO, 2012, p. 361-362). O emprego da primeira pessoa do plural junto de a gente é consequência direta da diminuição das idades e da escolaridade, o que sugere mudança linguística em progresso como também afirma Omena (1996, p. 192).

Rubio (2012), ao fazer uma comparação entre a variedade brasileira do interior paulista e a variedade europeia, traz argumentos em defesa de uma origem em comum e 
da deriva natural das línguas, adicionando evidências para a hipótese de Scherre e Naro (2007).

Em suma, a partir dos trabalhos do português brasileiro e do português europeu, pode-se ter uma visão panorâmica da variação linguística de nós e a gente em contextos de primeira pessoa do plural e de como esses resultados são importantes para o entendimento do fenômeno como um todo, das suas influências, das semelhanças e diferenças entre o português do Brasil e de Portugal. No português europeu, mesmo com pesquisas metodologicamente diferentes, o uso de nós é mais frequente do que no português brasileiro. Nesse sentido, o pronome a gente está mais avançado no português brasileiro como um todo. Para a maioria das amostras, a frequência de nós em Portugal, tomando Rubio (2012) como referência (58\%), apenas não é maior do que os dados do NURC (57,8\%) e os dados de Ponta Porã (61\%).

No próximo capítulo, então, serão analisados a teoria da Sociolinguística Variacionista, os procedimentos metodológicos, a pesquisa de campo, a constituição da amostra e a constituição da variável dependente e das variáveis independentes com suas respectivas hipóteses. 


\title{
CAPÍTULO 4 - PRESSUPOSTOS TEÓRICOS E PROCEDIMENTOS METODOLÓGICOS DA PESQUISA
}

\begin{abstract}
A realização de análises quantitativas possibilita o estudo da variação linguística, permitindo ao pesquisador apreender sua sistematicidade, seu encaixamento linguístico e social e sua eventual relação com a mudança linguística. A variação linguística, entendida como alternância entre dois ou mais elementos linguísticos, por sua própria natureza, não pode ser adequadamente descrita e analisada em termos categóricos ou estritamente qualitativos (GUY e ZILLES, 2007, p. 73).
\end{abstract}

Com o intuito de tornar claros os rumos do nosso trabalho, descrevemos a seguir os pressupostos teóricos e os procedimentos metodológicos de nossa pesquisa, a saber a escolha da comunidade e do fenômeno linguístico variável, a pesquisa de campo, a constituição da amostra, da variável dependente e das variáveis independentes nas entrevistas de Aceguá. No nosso trabalho, a variável dependente é a alternância pronominal nós e a gente como primeira pessoa do plural. As variáveis independentes são divididas em grupos de fatores linguísticos e sociais que podem condicionar ou não o uso de a gente ou nós, ou a ocorrência de determinada variante linguística.

\subsection{Teoria da Variação e da Mudança Linguística}

Os pressupostos teóricos de nosso trabalho são os da Teoria da Variação de Labov (2008 [1972]) e os da Teoria da Mudança Linguística de Weinreich, Labov e Herzog (2006 [1968]).

Em 1963, Labov publica um trabalho sobre a comunidade da ilha de Martha's Vineyard, no litoral de Massachusetts, destacando a relação dos fatores sociais em paralelo com a variação fonética do inglês. Assim, a centralização dos ditongos /ay/ e /aw/ é um traço linguístico e social vineyardense, porque representa identidade de pertencimento e atitude positiva à ilha (LABOV, 2008, p.57 e 59).

Em 1964, mostra a estratificação social do inglês em New York e estipula um modelo de descrição e interpretação do fenômeno linguístico conhecido como Sociolinguística Variacionista ou Teoria da Variação (LABOV, 2006).

O termo Sociolinguística surgiu em 1964, em um congresso organizado por William Bright, em Los Angeles, na Universidade da Califórnia (UCLA). Foi em 1966 que os trabalhos apresentados nesse congresso receberam o título de "Sociolinguistics". 
A proposta principal era relacionar variações linguísticas de uma determinada comunidade às diferenciações na estrutura social, econômica, cultural e política. A partir de então, a diversidade linguística, a identidade social do falante e do ouvinte, o contexto e o julgamento social são colocados como importantes para o estudo das variedades linguísticas (ALKMIM, 2005, p. 28).

Labov (2008, p. 13) resistiu ao termo sociolinguística, porque não concebia uma teoria ou prática linguística que não fosse também social, uma vez que as pessoas (falantes) fazem parte de uma grande organização social. A necessidade do surgimento de uma área ligada ao social pode ser explicada por meio da história da Linguística. Alguns estudiosos do passado, e até mesmo os mais atuais, estudam a língua(gem) por si só, como um fenômeno autônomo e externo ao falante, ignorando o contexto social em que a língua é usada. De fato, é nítido que se trata, acima de tudo, de propostas distintas de estudar a língua. Segundo Labov (2008, p. 21):

\footnotetext{
O ponto de vista do presente estudo é o de que não se pode entender o desenvolvimento de uma mudança linguística sem levar em conta a vida social da comunidade em que ela ocorre. Ou, dizendo de outro modo, as pressões sociais estão operando continuamente sobre a língua, não de algum ponto remoto no passado, mas como uma força social imanente agindo no presente vivo.
}

Na linguística do século XX, surge o estruturalismo saussureano em 1916. A dicotomia entre "langue" e "parole", depois reanalisada por Chomsky como "competência" e "desempenho", corrobora o estudo inatista da língua como um provável sistema homogêneo, diferentemente da fala. A fala, juntamente com os falantes e sua história cultural e social, não é o foco do estudo linguístico. Saussurre acreditava que o objeto deveria ser estudado a partir da estrutura interna da língua. Para as primeiras teorias estruturalistas, o estudo da mudança linguística e da estrutura linguística juntos seria muito complexo e difícil de correlacionar.

A partir dos anos de 1930, a questão social passa a ter maior importância para os fenômenos linguísticos. Alguns nomes se destacam como Antoine Meillet, Mikhail Bakhtin, Marcel Cohen, Émile Benveniste e Roman Jakobson. Cada um, em seus trabalhos específicos e diferenciados, traz uma concepção mais sociológica do falante e da língua, dizendo que a história das línguas está imbricada na história da cultura e da sociedade. Surge a ideia de comunicação social, comunicação verbal, linguagem como um reflexo do contexto social. Depois dos anos 1960, surgem outros estudiosos da 
relação entre linguagem e sociedade como John Gumperz, Einar Haugen, William Labov, Dell Hymes, John Fisher, José Pedro Rona (ALKMIM, 2005, p. 24).

Labov (2008, p. 302-306) diferencia dois grupos de estudo: um focado na abordagem individual, como Hermann Paul, Sweet, Martinet, Chomsky, Halle, e outro focado no lado social ou que leva em conta alguns pontos dessa abordagem, como Whitney, Meillet, Vendryes, Jespersen.

Em contraposição à Sociolinguística, Noam Chomsky trabalha com a concepção racionalista de fazer ciência. Essa visão, para Faraco (2005, p. 166), é apenas uma roupagem nova para a concepção de língua como algo vivo por si só, sujeito às leis da evolução, já que continua dando um tratamento sistêmico e estruturalista à mudança sem levar em conta a história social dos falantes. Ainda segundo Faraco (2005, p. 166167), as inovações são os fatos representados por regras e novos aparatos notacionais, além da hipótese inatista. Parece que são as velhas leis fonéticas dos neogramáticos reaparecendo, visto que os gerativistas acreditam que, embora cada língua fixe os parâmetros variáveis da gramática universal de formas diferentes, ocorrem semelhanças na fixação de determinados parâmetros.

A Sociolinguística trabalha com a diacronia e sincronia, e não somente com a sincronia saussurreana (homogênea, imutável e estática). Saussurre defendia uma separação maior entre o estudo sincrônico e diacrônico. No entanto, as duas análises devem caminhar juntas para explicar com eficácia os fenômenos ocorridos (todo fato sincrônico tem sua história), pois as línguas são objetos históricos. A doutrina uniformitarista ou princípio da uniformidade nos explica melhor sobre essa junção entre sincronia e diacronia, tendo em vista "a afirmação de que os mesmos mecanismos que operaram para produzir as mudanças em escala do passado podem ser observados em ação nas mudanças que presentemente ocorrem à nossa volta.” (LABOV, 2008, p. 192). Ou ainda: "as forças que operam para produzir a mudança linguística hoje são do mesmo tipo e ordem de grandeza das que operaram no passado, há cinco ou dez mil anos" (LABOV, 2008, p. 317). Por isso, é possível estudar a mudança em curso sincronicamente, mesmo que tenha sido iniciada há muito tempo, por meio da distribuição das várias faixas etárias.

É papel da Sociolinguística, também, descrever como o sistema linguístico é usado distintamente em várias comunidades de fala e como os usos da língua legitimam as pessoas que a falam, já que uma das principais funções da linguagem é a interação. 
Apesar disso, a língua também ser usada como forma de estabelecer e manter a coerção social.

Nesse sentido, a Sociolinguística pode ajudar na compreensão do caráter político-ideológico do uso da língua por todos os falantes nativos, visto que revela a covariação entre fenômenos linguísticos e fenômenos sociais, identificando diferenças dialetais e sociais, que, hoje, geram antagonismos sociais, que são reflexos de uma sociedade desigual. Para Alkmim (2005, p. 42):

\begin{abstract}
a intolerância linguística é um dos comportamentos sociais mais facilmente observáveis, seja na mídia, nas relações sociais cotidianas, nos espaços institucionais etc. A rejeição a certas variedades linguísticas, concretizada na desqualificação de pronúncias, de construções gramaticais e de usos vocabulares, é compartilhada sem maiores conflitos pelos não especialistas em linguagem. O senso comum opera com a ideia de que existe uma língua - o bem social à disposição de todos - que é adquirida distintamente, em função de condições diversas, pelos falantes. Na realidade, existe sempre um conjunto de variedades linguísticas em circulação no meio social.

(...)

Pensar que a diferença linguística é um mal a ser erradicado justifica a prática da exclusão e do bloqueio ao acesso a bens sociais. Trata-se sempre de impor a cultura dos grupos detentores do poder (ou a eles ligados) aos outros grupos - e a língua é um dos componentes do sistema cultural.
\end{abstract}

Somente a eliminação das discriminações e das desigualdades socioeconômicas poderia garantir aos falantes uma igualdade de conhecimento. Porém, a solução depende, antes de qualquer coisa, da mudança de atitude da própria sociedade, ou seja, de uma transformação da estrutura social, para que isso pudesse refletir no sistema político e linguístico. Para Sankoff (1988b, p. 143-144), há uma necessidade social para que sejam demolidos os estereótipos linguísticos a partir do estudo científico e variacionista.

A Sociolinguística também tenta romper essa visão de língua "perfeita" ou "ideal” mostrando que a variação não é caótica, mas sistemática. Além disso, é de suma importância que esse discurso não fique apenas nos meios acadêmicos, mas alcance de fato o senso comum e a comunidade em geral.

As posições polarizadas entre forma e função linguística, langue e parole, forma e uso, formalismo e funcionalismo, comunidade de fala e idioleto, competência e desempenho impossibilitam uma visão holística sobre os fenômenos linguísticos. Por isso, é necessário evitar dicotomias muito rígidas quando se trata do estudo científico da língua. Afinal de contas, a complexidade da língua envolve estruturas variáveis e invariáveis, além da inter-relação entre língua e fatores sociais. 
Historicamente, não é que a variação linguística nunca tivesse sido reconhecida. Mas era preferido supor, explicitamente ou não, que a língua era homogênea para trabalhar com seus próprios conhecimentos das regras sistêmicas da língua(gem), como uma ciência abstrata, autônoma e categórica. A variação ou era entendida como substituição de uma forma pela outra (variante livre ou aleatória), ou como variantes pertencentes a diferentes sistemas linguísticos, o que permitiria alternar de um para o outro (LABOV, 2008, p. 188).

O caminho central da teoria linguística passou pelos neogramáticos, estruturalistas e gerativistas. Para os neogramáticos, a mudança fonética era regular. Quando não se tinha a regularidade, explicava-se a exceção via analogia e empréstimo. No estruturalismo, os fonemas e morfemas eram vistos como elementos estruturais e invariáveis. No gerativismo, a preocupação é com os universais linguísticos e, portanto, com os elementos que não variam de uma língua para outra. E os universais de variação, onde ficam? Restava a tarefa de explicar os elementos particulares de outras línguas e a variação dentro de uma mesma língua. Ora, dentro da gramática de uma língua sempre existem processos pressupostamente opcionais que implicam variação, ou seja, realizações alternativas que passam a ser desvendadas pela Sociolinguística. Assim afirma Labov (2008, p. 151):

O estudo empírico das variantes linguísticas nos mostra que a estrutura linguística não está confinada às unidades invariantes, funcionais, como os fonemas, morfemas ou tagmemas. Ao contrário, existe um nível de estrutura variante que relaciona sistemas inteiros de unidades funcionais e que governa a distribuição de variantes subfuncionais dentro de cada unidade funcional.

Como o objeto de estudo da Sociolinguística, primeiramente, é a língua falada em seu contexto social, o (re)conhecimento das variedades linguísticas, juntamente com a comunidade de fala, ocupa um espaço de grande importância para esse campo do saber.

De uma forma geral, para a Sociolinguística (BAGNO, 2007, p. 46-47), a variação não só existe como pode ser geográfica ou regional, sociocultural (de sexo, de classe social, de escolaridade, de idade etc), estilística e outros. Na variação diatópica, geográfica ou regional, as variedades estão distribuídas de acordo com os falares ou dialetos regionais decorrentes do espaço físico e da área geográfica. O levantamento das diferentes variedades geográficas de uma língua revelou uma realidade muito mais complexa e heterogênea. 
Na variação diastrática ou sociocultural, as variedades se encontram distribuídas entre os dialetos sociais de acordo com a identidade e organização sociocultural e econômica dos falantes. Os fatores sociais que mais contribuem para a variação e mudança linguística são, principalmente, faixa etária, sexo e grau de escolaridade.

$\mathrm{Na}$ variação diafásica, situacional ou estilística, o grau de formalidade depende do tripé: ambiente, assunto e intercolutor. Segundo Bortoni-Ricardo (1998 e 2004), os falantes alternam estilos monitorados e não-monitorados. Assim, a monitoração estilística é vista como um continuum de fala que vai do mais formal até o mais informal. Tanto a fala quanto a escrita podem ser formais ou informais. Esses estudos são realizados pela Sociolinguística Interacional, e o efeito dos fatores interacionais e/ou estilísticos na variação é estudado pela teoria da variação e da mudança linguística.

Dentro da teoria da mudança linguística, pode-se analisar a mudança em curso, na qual as manifestações linguísticas estão concentradas no tempo presente, ou seja, nas gerações diferentes que estão convivendo em uma mesma época. Este é o estudo da mudança por meio do tempo aparente. No caso de Aceguá, as inovações da língua, como a inserção de a gente em contextos de primeira pessoa do plural, são, em termos de tendência, mais realizadas pelos jovens, enquanto os demais são conservadores com relação à mudança linguística, optando pelo uso de nós nesses mesmos contextos.

Os estudos em tempo real são constituídos pelas mesmas pessoas em diversas etapas de sua vida, como, por exemplo, em uma mesma amostra recontactada em diversas décadas. O tempo aparente se restringe a diferentes pessoas em diferentes etapas ou idades (NARO, 2004), como é o caso da nossa pesquisa.

Em suma, tentar entender a variação nas línguas é um objetivo da Sociolinguística, que entende todas as variedades como sistemas igualmente complexos, estruturados e sistemáticos. A Sociolinguística estuda a linguagem sob o prisma da heterogeneidade, explicitando os princípios internos (linguísticos) e os externos (experiências do falante e aspectos sociais). Citando Labov (2008, p. 140):

A variação no comportamento linguístico não exerce, em si mesma, uma influência poderosa sobre o desenvolvimento social, nem afeta drasticamente as perspectivas de vida do indivíduo; pelo contrário, a forma do comportamento linguístico muda rapidamente à medida que muda a posição social do falante. Essa maleabilidade da língua sustenta sua grande utilidade como indicador de mudança social. 
Assim, o comportamento linguístico pode ser entendido a partir de uma perspectiva social. Para entendermos como funciona a variação pronominal de primeira pessoa do plural, partimos do pressuposto de que a estrutura social da comunidade, como o bilinguismo, o sexo, a escolaridade, a faixa etária e o próprio contexto econômico-político da fronteira podem interferir direta ou indiretamente na escolha de uma variante em detrimento da outra, sobretudo no caso de a gente, que é tipicamente um pronome brasileiro. Certamente a influência brasileira (social, cultural, econômica e política) no contato de línguas na fronteira Brasil-Uruguai tem de ser levada em consideração para as análises linguísticas.

As contribuições da sociolinguística variacionista no entendimento das maneiras que as línguas variam e mudam são de suma importância para as variedades monolíngues. Mas também é importantíssimo o entendimento de como os fenômenos de contato e/ou convergência linguística se dão através de frequências e probabilidades correlacionadas com fatores linguísticos e extralinguísticos. Esta é a contribuição maior da sociolinguística variacionista para os estudos de dialetos em contato, sobretudo para complementar os estudos que generalizam estruturas que, sob a lente variacionista, revelam variação sistematizada (POPLACK, 1993).

A sistematização da variação é consequência da interpretação dos resultados linguísticos e sociais que também se inserem em um encaixamento maior dentro da teoria da mudança linguística de Weinreich, Labov e Herzog (2006, p. 126). O problema do encaixamento envolve dois aspectos: a mudança encaixada numa matriz de outras mudanças linguísticas e a mudança encaixada socialmente. Sobre esse encaixamento, Weinreich, Labov e Herzog (2006, p. 123) afirmam que

\begin{abstract}
a estrutura linguística mutante está ela mesma encaixada no contexto mais amplo da comunidade de fala, de tal modo que variações sociais e geográficas são elementos intrínsecos da estrutura. $\mathrm{Na}$ explicação da mudança linguística, é possível alegar que os fatores sociais pesam sobre o sistema como um todo; mas a significação social não é equitativamente distribuída por todos os elementos do sistema, nem tampouco todos os aspectos do sistema são equitativamente marcados por variação regional. No desenvolvimento da mudança linguística, encontramos estruturas linguísticas encaixadas desigualmente na estrutura social. (WEINREICH, LABOV E HERZOG, 2006, p. 123)
\end{abstract}

Assim, toda e qualquer variação é governada por fatores linguísticos e sociais. Sobre a mudança linguística, o efeito social não é distribuído igualmente por todos os elementos do sistema nem o sistema é marcado igualmente pelo social e geográfico. 
Então, cada fenômeno linguístico tem sua história sociolinguística em determinado contexto geográfico.

Antes de analisar todos esses condicionantes, é imprescindível também analisar o status da variável sintática dentro dos estudos sociolinguísticos. O fenômeno da alternância pronominal de primeira pessoa do plural é morfossintático e, por isso, se enquadra, de certa forma, na discussão sobre a variável sintática.

\subsection{A variável sintática e suas implicações}

Todas as línguas variam e mudam em relação ao tempo e à história, e a mudança linguística também é regida por fatores sociais, por meio da faixa etária e do processo sociocultural inerente às línguas. Para Labov (2008, p. 220-221), variação linguística é quando duas ou mais variantes têm o mesmo significado, a mesma referência e o mesmo valor de verdade.

É costume dizer que essas expressões têm o mesmo significado, o que podemos definir rigorosamente como "tendo o mesmo valor de verdade". O resultado final de nossos estudos da variação sintática será atribuir um sentido ou significação a uma transformação, um tipo de carga funcional que podemos querer distinguir nitidamente do significado representacional (LABOV, 2008, p. 221).

Labov (1994, p. 548) discute que as variantes podem apresentar nuances semânticas em termos de tendências, o que não compromete o valor de verdade, como, por exemplo, diferenças de ênfase, de figura/fundo, novo/velho, porque nunca estão em distribuição complementar.

Assim, as variantes nós e a gente têm o mesmo valor de verdade de pronome de primeira pessoa do plural e coexistem, com maior ou menor probabilidade, em contextos semelhantes de uso. É justamente o condicionamento linguístico e social que mostrará em que contextos uma variante ocorre mais em detrimento da outra. O fato de, por exemplo, os pronomes nós e a gente estarem ora em função genérica (com referência à terceira pessoa do plural), ora em função específica (com referência à primeira pessoa do plural) não invalida o conceito de variação linguística. Para Silva (2003, p. 69), 
ou nem chega a haver propriamente alternância, atuando aquela característica no sentido de determinar uma escolha. No último caso, acaba por se definir uma distribuição complementar entre as construções supostamente alternantes, já que não se encontram em variação num mesmo contexto.

Quanto às formas pronominais em questão, não há distribuição complementar com relação à referência específica ou genérica, por exemplo, mas apenas tendências, ou seja, a referência genérica tende a favorecer a gente e a referência específica tende a favorecer nós, mas existe a gente com referência específica e nós com referência genérica.

Se existisse distribuição complementar em termos de referência das duas variantes, ou seja, se todos os casos de nós estivessem sempre em contexto de referência específica e todos os casos de a gente estivessem sempre em referência genérica, não haveria variação laboviana. Muitas vezes, em um grupo de fatores de natureza semântica ou não, pode haver algum fator que favorece apenas uma das variantes, o que é chamado de efeito categórico, que, na maior parte das vezes, é parcial. A questão da possibilidade de distribuição complementar ou de significados e/ou funções completamente distintas para formas distintas pode existir, mas, nos fenômenos linguísticos analisados pelos trabalhos variacionistas, o entendimento é de que isso não ocorre sistematicamente.

Então, o estudo da variação linguística demonstra que as variantes coexistem em ambientes variáveis linguísticos e sociais. Da mesma forma que não existe homonímia perfeita, também não existem variantes perfeitas ou variantes idênticas do ponto de vista linguístico e social. Se isso fosse verdadeiro, realmente não existiria variação linguística, pois seu uso seria categórico nos mesmos contextos discursivos.

Sobre o status da variável sintática, surge uma discussão importante entre Labov (1978) e Lavandera (1978) sobre como e de que forma o problema da relação forma/função linguística surge e como ele pode ser abordado sistematicamente dentro do paradigma variacionista.

Para Lavandera (1978, p. 176), a diferença entre variáveis fonológicas e variáveis não fonológicas é que as variáveis fonológicas que apresentam significado social e estilístico não necessitam ter significado referencial, enquanto as variáveis não fonológicas são assim definidas mesmo quando portam significado social e estilístico, embora este significado referencial tenha de ser o mesmo para todas as variantes. 
Assim, segundo Lavandera (1978, p. 181), analisar alternativas sintáticas como variáveis sociolinguísticas depende das seguintes condições: (1) que se possa provar serem elas portadoras de alguma informação não referencial, tendo significado social, estilística ou outro; e (2) que elas provem ser um tipo de mecanismo da língua similar às variáveis fonológicas, ou seja, elementos cuja propriedade definidora é uma covariação quantitativa e para os quais as relações de freqüência sejam os verdadeiros sinais daquelas diferenças.

A proposta de Lavandera (1978, p. 181) é, então, alterar a concepção de "mesmo significado" ou "equivalência semântica" para a de "comparabilidade funcional", de forma a considerar variáveis linguísticas desde que veiculem informação não referencial (significado social e estilístico).

No entanto, em resposta a Lavandera, Labov (1978) insiste que, na variação linguística, há manutenção do valor de verdade e do significado referencial. O autor enfatiza, portanto, a noção de significado referencial ou representacional ou de estado de coisas, uma vez que dois enunciados que se referem ao mesmo estado de coisas têm o mesmo valor de verdade.

Oliveira (1987, p. 31 e 32) também mostra evidências para corroborar a tendência de que duas formas, num mesmo contexto, não dizem a mesma coisa quando: (i) uma variante elimina a outra e completa a mudança linguística; (ii) as variantes se contextualizam como alofones em distribuição complementar como a palatalização de /t/ e /d/ diante de -i; (iii) as variantes se contextualizam lexicalmente, uma vez que a alternância [o] e [u]; [e] e [i] pré-tônicos inexiste em grande parte do léxico (bonina, meninge); (iv) as variantes assumem significados diferentes; (v) as variantes são controladas pragmaticamente.

Tagliamonte (2006, p. 71) também trata da variável linguística e enfatiza que a questão é se, de fato, "duas formas de se dizer a mesma coisa" verdadeiramente ocorrem no âmbito da sintaxe e da semântica. E, se ocorrem, como podem ser reconhecidas, interpretadas e explicadas.

Em contrapartida, para Sankoff (1988b, p. 153), mesmo que haja alguma diferença conotativa entre itens lexicais ou estruturas sintáticas alternativas, essas distinções não atuam na intenção do falante nem na interpretação do interlocutor. Assim "as distinções no valor referencial ou na função gramatical entre formas superficiais diferentes podem ser neutralizadas no discurso", mecanismo discursivo fundamental da variação não fonológica e da mudança. 
Não existe, portanto, nenhum outro acesso mais direto às intenções dos falantes a não ser por meio dos enunciados que eles produzem, tanto quanto não temos acesso às interpretações dos ouvintes a não ser por meio de suas respostas em situações naturais, ou seja, não é possível prever se uma forma foi usada em vez da outra por alguma distinção sutil ou se foi feita uma livre escolha entre duas ou mais alternativas igualmente úteis. Assim, na variável sintática o mesmo valor de verdade e o mesmo contexto não são absolutos, mas não há motivos para desprezá-los (SANKOFF, 1988b, p. 154).

Em suma, esses foram os pressupostos teóricos da teoria da Variação e da Mudança Linguística e da configuração de uma variável sintática. Na próxima seção, o foco será nos procedimentos metodológicos e nas decisões tomadas para a análise variacionista.

\subsection{Procedimentos metodológicos}

A seguir, são explanados os procedimentos metodológicos utilizados para a pesquisa, tais como os aspectos quantitativos e qualitativos utilizados de forma complementar para nossa análise; a pesquisa de campo; a constituição da amostra; como funciona a variação nós e a gente na fronteira; a constituição da variável dependente e das variáveis indendentes linguísticas e sociais; e as hipóteses que constituem cada uma das variáveis.

\subsubsection{Aspectos quantitativos e qualitativos}

Nesta seção, busca-se explicitar os procedimentos metodológicos subjacentes à análise dos dados. A análise quantitativa dos dados é feita através do pacote de programas Goldvarb-X (Sankoff; Tagliamonte \& Smith, 2005) e a análise qualitativa é voltada para a discussão da identidade sociolinguística da fronteira a partir dos significados sociais construídos para as variantes nós e a gente. A união metodológica quali-quanti é reforçada pelos autores Flick (2009), Cardoso (2013) e Günther (2006).

A Teoria da Variação e Mudança Linguística, segundo Weinreich, Labov e Herzog (2006), tem os seguintes princípios: a variabilidade inerente a qualquer língua ou a diversidade linguística é fundamental, essencial e inevitável; a heterogeneidade é 
ordenada e probabilisticamente estruturada; e a estrutura linguística está atrelada à interferência do contexto social.

Nosso estudo enquadra-se, pois, na área de pesquisa da Sociolinguística Variacionista ou Quantitativa, com o auxílio do programa Varbrul, considerado um instrumental de análise, porque para Labov a teoria linguística tem de se basear em pesquisas empíricas e quantitativas, e não simplesmente intuitivas. Não basta identificar uma variação linguística com base em enunciados criados pelo próprio pesquisador ou achar e pressupor que determinada variação linguística existe. É imprescindível fazer pesquisa de campo e entrevistas para posteriormente codificá-las e submetê-las a tratamento estatístico. Assim podem-se fazer generalizações e análises sobre os resultados linguísticos e sociais empiricamente comprovados.

Os programas quantitativos são ferramentas de pesquisa que fazem parte da metodologia, assim como todo processo da pesquisa de campo como as entrevistas, a constituição da amostra, a definição da variável dependente e das variáveis independentes.

Como trabalhamos com muitos dados, seria praticamente impossível analisá-los a "olho nu". Para isso, recorremos à análise estatística que nos dá uma probabilidade geral e uma média global do fenômeno em questão e nos auxilia na verificação de variáveis que condicionam a ocorrência da variável sociolinguística focalizada, no caso, a variação pronominal de primeira pessoa do plural. Pensamos em algumas variáveis que poderiam influenciar o fenômeno em questão, reproduzimos outras que foram testadas em trabalhos sobre a gente e nós e codificamos outras apenas para controlar os dados, sem nenhuma hipótese prévia. Antes da análise estatística por meio do programa Varbrul, não sabemos se todas as variáveis são significativas. É este programa que testa as hipóteses alternativas propostas pelo analista, extraindo regularidades e tendências a partir dos dados aparentemente aleatórios (SANKOFF, 1988a).

No nosso caso, a variável dependente é o fenômeno a ser analisado, ou seja, a variação pronominal de primeira pessoa do plural. As variantes são as formas diferentes de se falar a mesma coisa, em um mesmo contexto e com mesmo valor de verdade, que, no nosso caso, seria o uso de a gente ou o uso de nós. De acordo com Labov (2008, p. 313): “A variação social e estilística pressupõe a opção de dizer 'a mesma coisa' de várias maneiras diferentes, isto é, as variantes são idênticas em valor de verdade ou referencial, mas se opõem em sua significação social e/ou estilística”. 
Já as variáveis independentes são todos os grupos de fatores linguísticos ou sociais que codificamos para testar as hipóteses dos condicionamentos do fenômeno variável em análise.

Os resultados da análise serão apresentados em tabelas, que mostrarão exemplos das variáveis linguísticas e sociais, a frequência absoluta, o total de dados, a frequência relativa, o peso relativo e, em alguns casos, o range.

Segundo Tagliamonte (2006, p. 242), o range é a diferença entre o fator de maior peso e o de menor peso de determinada variável linguística ou social. Quando esses números são comparados em cada um dos grupos de fatores de uma análise, o número mais elevado do range identifica a restrição mais forte. $\mathrm{O}$ menor número identifica a restrição mais fraca. $\mathrm{O}$ range (ou magnitude de efeito) permite situar grupos de fatores com relação ao outro. Ainda de acordo com Tagliamonte (2006, p. 245), o range ajuda a determinar a localização de cada variedade ao longo da trajetória da mudança que está em curso na língua.

A frequência absoluta é o número de dados de cada fator, seja em relação ao total dos fatores, seja em relação às variantes. Já a frequência relativa é a medida em percentagem do efeito do fator isolado, e, portanto, se faz necessário o cálculo dos pesos relativos, que são uma espécie de frequência corrigida, já que apresenta o efeito de um fator perante todos os outros. É justamente na comparação de um fator em relação aos outros fatores que consiste a análise multivariada ${ }^{70}$.

Além disso, como a distribuição dos grupos de fatores ou dos dados extraídos do corpus pode ser irregular, o peso relativo também é responsável por corrigir esse “desequilíbrio", já que o número de ocorrências de cada contexto é variável e muitas combinações de fatores podem não ocorrer, ficando células vazias (SANKOFF, 1988a). O possível enviesamento com relação ao número de células por grupo social, ao número de dados de cada colaborador ou às diferenças no tempo de gravação de cada entrevista também pode ser corrigido por meio do peso relativo (GUY e ZILLES, 2007, p. 47-70), desde que o desequilíbrio não seja excessivamente forte. Guy e Zilles (2007, p. 106) retomam essa problemática e dizem que:

É muito fácil obter percentuais para um conjunto de contextos que distorcem ou até invertem o efeito real, por causa de uma distribuição desequilibrada desses contextos em relação a outros que não eram considerados, mas uma

\footnotetext{
${ }^{70}$ Para maiores esclarecimentos sobre a metodologia quantitativa, conferir Sankoff (1988 a e b), Guy (1998), Naro (2004), Scherre e Naro (2004), Tagliamonte (2006), Guy e Zilles (2007).
} 
análise multivariada procura produzir um cálculo de efeitos que sempre controla simultaneamente todos os contextos e variáveis independentes.

Para interpretar os resultados estatísticos do Varbrul em termos de pesos relativos, é preciso saber que os valores podem variar entre 0 e 1 . É considerada uma variante favorecedora para o fenômeno quando o resultado está acima de 0,5; abaixo de 0,5 significa que o fator desfavorece (baixa probabilidade) o fenômeno; e na faixa de 0,5 pode significar que o fator tem efeito intermediário, ou seja, pode nem favorecer e nem desfavorecer. Segundo Naro (2004, p. 24),

\begin{abstract}
Os pesos calculados de acordo com o modelo logístico costumam ser interpretados como favoráveis à aplicação da regra, se forem superiores a 0,5; como inibidores, se forem inferiores a 0,5; e como neutros, se forem iguais a 0,5. Entretanto, é necessário sempre ter presente o fato de que a solução numérica da equação logística é até certo ponto arbitrária. [...] Por isso, temos que ter muita cautela ao dizermos que um peso menor do que 0,5 desfavorece a aplicação da regra ou ao compararmos valores numéricos de pesos calculados para diversos conjuntos de dados.
\end{abstract}

Segundo Guy e Zilles (2007, p. 238-239), há diferença entre o peso relativo interpretado como neutro e o peso relativo que tem efeito levemente favorecedor ou leveremente desfavorecedor, mesmo que próximos de 0,50. Numa análise binária, como a nossa,

\footnotetext{
Em termos de percentuais, um fator associado com um peso de 0,50 deve ter uma frequência de ocorrência que se aproxime da frequência total observada em todo o corpus. Convém notar que um fator associado à grande maioria dos dados necessariamente ficará com um peso perto do ponto neutro (GUY e ZILLES, 2007, p. 239).
}

Agora, não se pode esquecer que um fator com peso relativo muito baixo também é altamente importante no sentido de desfavorecer a outra variante da variável dependente sob foco. Sankoff (1988a) enfatiza, todavia, que o mais importante é a diferença entre os diversos pesos relativos de uma mesma variável dependente.

Se um resultado dá $100 \%$ ou $0 \%$ de frequência (ocorrências categóricas de uma dada variante em função de um dado fator), o programa não projeta os pesos relativos, porque esse modelo logístico foi criado para analisar fenômenos variáveis estruturados, e não categóricos. Logo, o programa acusa os knockouts, que são efeitos categóricos.

Assim sendo, precisamos analisar os fatores de forma a amalgamá-los (juntar fatores) ou retirá-los da análise de pesos relativos. Se um dado fator for de real efeito 
categórico, a decisão correta ou adequada é retirá-lo da análise de projeção dos pesos relativos, porque só o contexto (ou fator) em questão dá conta de forma completa de uma dada variante.

Segundo Tagliamonte (2006, p. 141), o percentual geral corrigido do fenômeno é chamado de input, também conhecido como "média corrigida", é uma medida global da força e da taxa de aplicação da regra (Guy, 1988, p. 126). É a frequência média de ocorrência da variável dependente.

Sobre as variáveis independentes, Guy e Zilles (2007, p. 65) afirmam que nem sempre os grupos de fatores têm efeitos independentes. Ao se detectar uma possível interação entre duas variáveis, é importante realizar alguns cruzamentos para constatar, entender e resolver a influência de uma sobre a outra. Esse procedimento é feito cruzando duas variáveis independentes a fim de estabelecer a relação existente entre elas. Assim, busca-se o entendimento global da variação linguística com o auxílio do suporte quantitativo.

Para Sankoff (1988a, p. 8), a interação diz respeito a não uniformidade do efeito dos fatores. Nem é comum haver interação entre grupos de fatores propriamente linguísticos. A interação encontrada é, frequentemente, resultado de má definição da codificação de fatores ou formulação inadequada de grupos de fatores, de tal forma que a descoberta de interação frequentemente conduz à reformulação da análise linguística do processo de escolha (SANKOFF, 1988a, p.28). A interação também pode ocorrer entre os fatores sociodemográficos, e, nesse caso, é preferível substituir todos esses fatores por um único grupo de fatores, como a identificação do falante (SANKOFF, 1988a, p. 30).

Em suma, sobre o papel da estatística, Naro (2004, p. 25) esclarece que a metodologia da Teoria da Variação constitui uma ferramenta importante para analisar o fenômeno da variação, mas

\footnotetext{
As suas limitações são as do próprio linguista, a quem cabe a responsabilidade de descobrir quais são os fatores relevantes, de levantar e codificar os dados empíricos corretamente, e, sobretudo, de interpretar os resultados numéricos dentro de uma visão teórica da língua. O progresso da ciência linguística não está nos números em si, mas no que a análise dos números pode trazer para nosso entendimento das línguas humanas.
}

Guy e Zilles (2007, p. 69-70), três anos depois, também fazem uma declaração bastante importante sobre esse aparato quantitativo: 
O Varbrul é uma ferramenta poderosa e extremamente útil para a análise da variação linguística. Como acontece com qualquer ferramenta, sua utilidade é acentuada por uma compreensão de suas operações e de suas limitações. Mas não se deve nunca perder de vista o fato de que, na análise final, o Varbrul é apenas um recurso (embora sofisticado) para a manipulação dos dados. Não discerne padrões, não faz generalizações, nem explica achados. Isso tudo é com você.

Dessa forma, cabe somente ao pesquisador a interpretação dos dados e as correlações necessárias com base na teoria linguística. O programa apenas nos dá um suporte quantitativo, mas os números em si podem não dizer absolutamente nada. Segundo Sankoff (1988a), os valores estatísticos não são apenas refinamentos quantitativos no julgamento da gramaticalidade; eles representam mais do que isso e sugerem outras reflexões sobre os aspectos que emergem ou não no uso da língua. $\mathrm{O}$ Varbrul, como ferramenta estatística, serve como um instrumento para entender a interrelação entre os vários fatores sociais e linguísticos de uma situação complexa.

Para Scherre e Naro (2004, p. 176), a estatística revela tendências e correlações inerentes à grande quantidade de dados linguísticos a fim de validá-los dentro de um determinado grau de certeza, por isso é uma ferramenta valiosa que amplia a capacidade de análise do uso linguístico.

A partir desses resultados estatísticos, percebemos que seria importante, para essa pesquisa, unir as abordagens quantitativa e qualitativa no sentido de complementar a análise variável do pronome de primeira pessoa do plural com as questões identitárias da fronteira. Essas abordagens são distintas epistemologicamente, mas totalmente possíveis do ponto de vista da complementaridade dos estudos e de uma abordagem mais multidisciplinar e geral, como já acontece, por exemplo, entre a Sociolinguística Variacionista e a Gerativa, denominada Sociolinguística Paramétrica. Há linguistas, como Neto (2004, p. 197-200), no entanto, que não concordam com a união da Sociolinguística e da Gerativa, porque acreditam que as diferenças entre ambas podem inviabilizar os estudos.

Acerca da união metodológica de uma abordagem micro e macro, Flick (2009) aborda a questão com muito cuidado alertando-nos para o fato de não torná-las contraditórias, e sim complementares. O importante é que nenhuma metodologia e teoria sejam menosprezadas e desprestigiadas em detrimento da outra. Segundo o mesmo autor, dados qualitativos podem se transformar em dados quantitativos e viceversa, com a comparação, por exemplo, de métodos qualitativos e quantitativos, 
conhecida como triangulação (FLICK, 2009, p. 39 e 43). Essa transformação de dados será útil para a formulação das hipóteses, tendo em vista que já foram (re)elaboradas mediante uma observação participante prévia da comunidade.

Segundo Cardoso (2013, p. 144), a diferença não está na espistemologia da sociolinguística qualitativa e quantitativa, porque a sociolinguística como um todo é a ciência que estuda a língua atrelada ao social. Assim, a diferença depende das perguntas de pesquisa e do que se quer entender. Segundo Sankof (1988b, p. 140), para o estudo da variação linguística, sobretudo sintática, o status epistemológico é de uma metodologia interpretativo-descritiva para lidar com o problema forma-função.

Entende-se, portanto, que é "possível, desejável e perfeitamente aceitável uma relação entre a postura quantitativa e a qualitativa em pesquisas sociolinguísticas", pois, "Do contrário, assume-se uma única postura metodológica e não se reconhece a possibilidade de caminhos alternativos para lidar com a infinidade de comportamentos, olhares e [inter]ações existentes a respeito do objeto de estudo" (CARDOSO, 2013, p. 155-156).

Cardoso (2013, p. 151) relembra que a própria investigação científica de Labov sobre a mudança sonora (centralização dos ditongos /aw/ e /ay/) na ilha de Martha's Vineyard, em Massachussets, Estados Unidos, apresenta-se como exemplo de pesquisa que trabalha coadunando as abordagens quali-quanti, uma vez que traz resultados estatísticos, mas também observações diretas sobre o fenômeno linguístico em questão, a cultura, a história, a sociedade e a língua da comunidade. Pensando por esse lado, o trabalho variacionista certamente traz elementos da abordagem qualitativa, já que geralmente traz todos esses olhares em busca do entendimento global da variação e da mudança linguística.

Guy e Zilles (2007, p. 129) também afirmam a importância de combinar métodos qualitativos e quantitativos, porque os dados complementares ajudam na análise dos dados e fazem parte da abordagem da "triangulação". Para Günther (2006, p. 207), "Enquanto participante do processo de construção de conhecimento, idealmente, o pesquisador não deveria escolher entre um método ou outro, mas utilizar as várias abordagens, qualitativas e quantitativas, que sejam necessárias à sua questão de pesquisa".

Logo, o ponto-chave para essa perspectiva de estudo é combinar métodos de pesquisa qualitativos e quantitativos, como entrevistas abertas, investigações 
documentais, notas de campo, vídeos, fotografias, observação participante, observação anônima e a etnografia, como forma de observação contínua na pesquisa de campo.

Segundo Labov (2008, p. 110), há outros métodos que podem ser confrontados com os resultados obtidos por meio das entrevistas tipicamente labovianas, como é o caso da observação aleatória e anônima. Assim, a interferência do linguista tende a ser neutralizada. Nesse sentido, as interpretações também são consequência da vivência pessoal do pesquisador com a comunidade na época da pesquisa de campo, e não necessariamente explicações exclusivas das entrevistas. Também é sempre importante confrontar interpretações do pesquisador com a visão do próprio pesquisado. Para Silva (1998, p. 18)

\footnotetext{
A relação desejada entre o quantitativo com o qualitativo pode ser considerada complementar. Ou seja, enquanto o quantitativo se ocupa de ordens de grandezas e as suas relações, o qualitativo é um quadro de interpretações para medidas ou a compreensão para o não quantificável.
}

O pressuposto principal dessa abordagem complementar é o de que o método se ajusta ao objeto de estudo e não o contrário, ou seja, a metodologia é dada pelo objeto de pesquisa. Por isso, pela característica complexa do projeto, faz-se necessária a utilização de mais de um método de análise (multimetodologia) para se levar em conta tanto os objetivos do pesquisador quanto do pesquisado, de forma recíproca.

Constantemente, tenho presenciado pesquisadores fazerem uma falsa dicotomia entre abordagem quantitativa e abordagem qualitativa, como se ambas fossem diametralmente opostas, com o discurso de que esta abordagem tem primazia sobre aquela, uma vez que é responsável pela interpretação subjetiva da pesquisa. Assim, é problemático julgar a metodologia variacionista como se fosse apenas um resultado em forma de números e meramente formal e matemático.

Além disso, frequentemente, confunde-se o programa de estatística com o próprio pesquisador, já que há uma falácia em que se diz que o programa é quem analisa os dados. Ora, é imprescindível entender que não existe pesquisa quantitativa que não seja também qualitativa. Afinal de contas, os resultados devem ser explicados e analisados conforme o quadro teórico a que se vincula o estudo. O contrário não é verdadeiro, ou seja, pode haver pesquisa qualitativa sem nenhum suporte quantitativo. Por isso, sigo sem entender tamanha ruptura idealizada por outros, já que as pesquisas variacionistas são essencialmente descritivas e explicativas, porque partimos de 
hipóteses sobre a língua e, posteriormente, utilizamos os resultados estatísticos para explicar os padrões sociolinguísticos mais gerais de determinado fenômeno. Outro ponto forte é que ambas as abordagens de pesquisa se realizam por meio da fala ou interação real dos colaboradores, e as entrevistas não precisam ser necessariamente préprogramadas.

Dessa forma, no nosso caso, o suporte quantitativo será destinado à análise variável dos pronomes de primeira pessoa do plural e, consequentemente, dos padrões linguísticos, sociais e estilísticos que a condicionam. E a abordagem qualitativa está presente, especialmente, na retrospectiva histórica, social, cultural e geográfica da comunidade, na análise de empréstimos linguísticos, code-switching, nas identidades sociolinguísticas dos fronteiriços e na descrição do fenômeno variável em si em consonância com as interpretações do pesquisador por meio de observação participante.

De acordo com Labov (2008, p. 83), "quando fazemos uma abordagem a partir de duas direções diferentes e obtemos o mesmo resultado, podemos ter certeza de que conseguimos vencer o paradoxo do observador no sentido de que a estrutura existe independentemente do analista". Muitos linguistas, especialmente da pesquisa qualitativa, não aceitam que essa estrutura linguística se manifeste sem a interferência do pesquisador. No entanto, acreditamos que o fato de resultados se repetirem significa que os padrões sociais e linguísticos se mantiveram independentemente da presença de alguém. Seria, portanto, a prova dos nove de que o paradoxo do observador pode ser minimizado dependendo da forma como a entrevista é guiada.

Nesse sentido, Labov (2008, p. 244) afirma que, para anular o efeito do paradoxo do observador, devemos achar outras maneiras de suplementar as entrevistas formais com outros dados. As consequências do paradoxo do observador poderiam resultar em um possível enviesamento da pesquisa, uma vez que o objetivo do linguista é saber como as pessoas falam quando não estão sendo sistematicamente observadas. Todavia, só podemos obter esses dados por meio de uma observação sistemática (LABOV, 2008, p. 244). É justamente esse dilema que se denomina paradoxo do observador.

Para averiguar a questão da qualidade na pesquisa, houve a validação da situação de entrevista, que é demonstrar confiabilidade entre pesquisador e pesquisado. A triangulação também foi utilizada, já que a união de métodos diferentes pode evitar erros e distorções na pesquisa (GÜNTHER, 2006, p. 206). Para isso, estabelecemos 
contato com moradores de Aceguá e nos comunicamos ao longo de todos esses anos de pesquisa, sempre solicitando mais informações e confrontando nossas percepções.

Pretende-se também divulgar a pesquisa para a comunidade de Aceguá e, principalmente, para as escolas do município, visando a uma reflexão de todos os envolvidos no processo para que o ensino de português e espanhol leve em consideração, também, toda essa variedade linguística presente na fronteira e descrita nesse trabalho, além de os moradores terem acesso a registros reunidos da parte histórica e geográfica de Aceguá.

\subsubsection{A pesquisa de campo}

Situações de contato de línguas são altamente variáveis e interessantes para estudos sociolinguísticos. Ainda assim, se compararmos com o português brasileiro, o português da fronteira e o português uruguaio, de modo geral, carecem de mais estudos voltados para a Sociolinguística, sobretudo, variacionista.

$\mathrm{Na}$ falta de mais estudos e mais informações sobre Aceguá, sobretudo no que diz respeito à Sociolinguística local, houve a necessidade de já iniciar a primeira parte da pesquisa de campo, que foi feita em outubro de 2009 (14/10/09 a 19/10/09), a fim de compor melhor o projeto de pesquisa para o doutorado. Na região, consegui materiais na biblioteca da escola "Barão de Aceguá", na prefeitura municipal e com algumas pessoas que arquivavam documentos históricos. Além disso, foi nessa viagem que fiz os primeiros contatos com alguns moradores, os quais me ajudaram bastante na segunda viagem $(07 / 09 / 11$ a 19/09/11), e através de contatos por e-mail para tirar dúvidas e confirmar alguma informação da região ou dos colaboradores. Tudo isso ampliou a confiabilidade da pesquisa em Aceguá.

O termo colaborador é usado na pesquisa qualitativa (FLICK, 2009) e será utilizado na nossa pesquisa. O termo informante será preservado quando se tratar de citação direta ou indireta de autores que utilizam essa nomenclatura. No entanto, para esse trabalho, o termo colaborador será utilizado por ser mais significativo quando se entende que os entrevistados de uma pesquisa participam do estudo, e não simplesmente fornecem informações. Inclusive, até as empresas privadas têm optado por chamar seus funcionários de colaboradores, no intuito de o tratamento ser mais íntimo e respeitoso. Nesse sentido, entendemos que, além de darem entrevista, os colaboradores participaram ativamente da minha estada em Aceguá, me indicaram novos 
colaboradores e me inseriram em várias práticas sociais, permitindo-me vivenciar um pouco da experiência deles.

Assim, para a primeira pesquisa de campo, fiz entrevistas apenas com brasileiros nascidos na fronteira de Aceguá ou em regiões próximas, como Bagé, tendo em vista o pouco tempo da viagem. Para a codificação dos dados, foi dada prioridade aos aceguaenses ou aos que já moravam no local há bastante tempo, já que alguns entrevistados não moravam mais em Aceguá, eram crianças ou falavam muito pouco na entrevista.

O intuito principal era observar, num primeiro momento, como se dava o contato linguístico na região e como as pessoas viviam na fronteira. $\mathrm{Na}$ época, havia feito um pré-projeto anterior à viagem e outro depois da viagem. A diferença entre os dois projetos foi grande, o que demonstra que só vivenciando a prática sociolinguística das comunidades que se torna possível um entendimento maior dos fenômenos linguísticos.

Primeiro, tinha a impressão de que o português a ser pesquisado seria o dos brasileiros, porque não entendia que uruguaios falassem português como língua materna, ainda que tivesse lido alguns textos sobre a realidade linguística dessa fronteira. Posto isso, nessa primeira viagem, fiz as entrevistas apenas com os monolíngues brasileiros.

Depois da pesquisa de campo, compreendi mais a predominância do português na região, e que do lado brasileiro era mais difícil encontrar bilíngues do que do lado uruguaio. Ainda assim, notei que muitos colaboradores falavam comigo em português, mas, quando passava algum falante de espanhol, mudavam para o espanhol. Como meu contato com os uruguaios tinha sido mais nos comércios da fronteira, percebi que eles não falavam português comigo, mas sim o espanhol. Os moradores também demonstraram certa insegurança linguística, porque tinham dúvida quanto à língua que falavam e afirmavam não saber falar português direito, embora estivessem falando português. Essa impressão errônea sobre sua própria língua materna é comum aos falantes dos dialetos monolíngues.

Outro fato curioso é que a escola brasileira ensina o espanhol da Espanha como língua estrangeira, ignorando a variedade uruguaia vivenciada dia e noite na fronteira. $\mathrm{Na}$ escola uruguaia, também se ensina o português padrão como língua estrangeira. Era também muito comum ver brasileiros casados com uruguaios e uruguaios casados com brasileiros, e uruguaios que trabalham no Brasil e brasileiros que trabalham no Uruguai. Logo, os laços familiares e profissionais mantêm o povo bastante unido. As crianças são 
educadas para preservar e respeitar a cultura de ambos os países, como eles mesmos afirmam.

As variáveis sociais puderam ser revistas e descritas por meio das hipóteses com base na pequena vivência na fronteira, ainda que eu não tivesse escolhido o fenômeno linguístico.

Depois de realizada a primeira etapa da pesquisa, o projeto foi escrito e submetido ao Programa de Pós-Graduação em Linguística da UnB (PPGL). Até então, não sabia que fenômeno linguístico seria investigado, porque também não tinha realizado entrevistas do lado do Uruguai. Por isso, depois de entrar no Doutorado em 2010, aguardei até a próxima ida a campo, em setembro de 2011, para complementar as entrevistas e identificar algum fenômeno linguístico variável dos dois lados da fronteira, já que o objetivo era analisar o português tanto de brasileiros quanto de uruguaios numa perspectiva que levasse em conta a comunidade como um todo.

$\mathrm{Na}$ primeira viagem a campo, obtive informações de que todo ano os moradores comemoram a Semana Farroupilha, uma semana típica de festejos e comidas para celebrar e difundir a cultura gaúcha, realizada em todo o território do Sul do Brasil. Logo, optei por fazer a segunda viagem em setembro de 2011 para participar da Semana Farroupilha. Nessa ocasião, visitei a escola integral, a escola técnica do Uruguai e conheci um pouco mais da região de Aceguá-Uruguai.

Fiz entrevistas com uruguaios e algumas com brasileiros, já que na primeira viagem só havia feito entrevista com brasileiros. As entrevistas foram feitas na casa dos colaboradores ou em restaurantes e lugares públicos e descontraídos, a fim de coletar o vernáculo fronteiriço.

O contato inicial com os colaboradores também foi muito importante, porque eles mesmos me indicaram amigos e parentes e foram comigo na casa deles. A presença de alguém da própria comunidade também favorece um ambiente mais informal e tranquilo para as entrevistas, minimizando os efeitos do "paradoxo do observador", mostrado por Labov. Assim, os colaboradores foram instigados a contar histórias de Aceguá, suas próprias experiências pessoais, além de assuntos gerais como futebol, política, gastronomia, língua, agricultura, ensino.

Posteriormente, as entrevistas foram transcritas de forma mais ortográfica do que fonética, mas mantendo o vernáculo dos entrevistados e as interferências do espanhol. Adiante há mais detalhes sobre a constituição da amostra e das variáveis. 


\subsubsection{A constituição da amostra}

Antes da entrevista propriamente dita, o entrevistado pode fazer alguma brincadeira ou comentário simpático com o entrevistador, alguma observação corriqueira a alguém da família ou até mesmo se dirigir a uma terceira pessoa no meio da entrevista. Esse tipo de situação favorece mais o uso do vernáculo, ou seja, o uso de uma língua menos monitorada em um contexto mais natural (LABOV, 2008, p. 111114). Ainda segundo Labov (2008, p. 141), se o contexto não evidencia, em geral, o vernáculo, é imprescindível realizar tambem observações anônimas. No entanto

\footnotetext{
Não importa que outros métodos possam ser usados para obter amostras da fala (sessões de grupo, observação anônima), a única maneira de obter bons dados de fala em quantidade suficiente é mediante a entrevista individual, gravada, ou seja, por meio do tipo mais óbvio de observação sistemática (LABOV, 2008, p. 244).
}

Para auxiliar as entrevistas tipicamente labovianas e minimizar o efeito do paradoxo do observador, o tipo de amostra escolhido leva em consideração aspectos importantes para obtermos "resultados confiáveis", tais como indicação de entrevistados pelos próprios membros da comunidade; observação participante ou anônima do pesquisador.

Portanto, a amostra não é aleatória, ou seja, os entrevistados não foram selecionados ao acaso, de forma arbitrária. Milroy \& Gordon (2003, p. 25-32) descrevem três tipos de metodologia: (i) amostragem aleatória (random sampling); (ii) bola de neve (snowball sampling); (iii) amostragem por cotas ou amostragem de julgamento (quota/judment sampling).

A amostragem aleatória é a amostra ideal para a estatística e, consequentemente, a preferida de Labov, já que é uma amostra em que todos os membros da comunidade têm a mesma chance de serem selecionados.

A amostragem bola de neve é aquela em que o próprio colaborador vai indicando novos colaboradores para a pesquisa, criando uma espécie de rede social. Nessa amostra, o pesquisador tende a causar menos estranheza, uma vez que é indicado por um membro da própria comunidade. Esse tipo de entrevista favorece também o estudo de redes sociais (MILROY, 1980).

Essa foi a amostragem. Quando fui a Aceguá pela primeira vez, em outubro de 2009, não conhecia ninguém da cidade. Assim, a primeira ideia foi visitar as escolas e a 
prefeitura. Chegando à prefeitura, entrevistei alguns funcionários e já fui pedindo indicação de quem eu poderia entrevistar. Rapidamente, eles já foram me indicando alguns moradores da região. Cada colaborador entrevistado também me indicava novas pessoas, amigos ou parentes próximos. Durante a segunda pesquisa de campo, em setembro de 2011, como eu já tinha conhecido alguns moradores na última viagem, continuei sendo indicada por outros colaboradores.

As entrevistas foram feitas, preferencialmente, nas instituições públicas onde as pessoas trabalhavam ou na própria casa delas, a fim de tornar o ambiente o mais familiar e íntimo possível, estimulando o vernáculo local. Em algumas entrevistas, estava presente o próprio membro da comunidade que havia indicado aquela pessoa agora entrevistada. Assim, o colaborador que indicava alguém, normalmente, desempenhava a função de mediador entre a pesquisadora e o entrevistado.

Outro motivo para a escolha da amostra bola de neve, além das redes sociais e da tentativa de me aproximar da língua real local, é que, em se tratando de fronteira, a abordagem tem de ser diferenciada por conta das circunstâncias peculiares da região.

Um exemplo de possíveis contratempos que podem ocorrer caso a intervenção seja aleatória foi quando me aproximei de uma borracharia para conversar com alguns senhores que ali estavam. Depois de uma apresentação pessoal e dos objetivos da pesquisa, percebi que, ainda assim, os moradores não se sentiam à vontade com a minha presença. Após alguns minutos de entrevistas, um senhor se assustou com o gravador e me perguntou porque eu tinha de gravá-los. Nesse momento, estávamos conversando sobre o contrabando local, e a impressão foi que eles tiveram receio de que alguma informação vazasse ou de que eu poderia ser uma funcionária da polícia ou algo parecido. Essas situações constrangedoras não aconteciam quando havia alguém da própria comunidade comigo ou quando o participante era indicado de algum conhecido.

Portanto, a pesquisa não se limita à representatividade ${ }^{71}$ da amostra aleatória, em que todos teriam iguais chances de serem incluídos na amostra. Todavia não deixa de ter validade e confiabilidade no sentido de ser uma amostra que, devido às circunstâncias já mencionadas, precisa ser constituída com base nas redes sociais. Por isso, reconhecemos os limites dos resultados como válidos para o estudo em questão.

O termo amostra exige a representatividade, pois se refere ao grupo de indivíduos selecionados para representar a comunidade em questão, uma vez que o comportamento

\footnotetext{
${ }^{71}$ Sobre a discussão de amostra, corpus, representatividade e confiabilidade, conferir capítulos 8 e 9 de Guy e Zilles (2007, p. 108-134).
} 
linguístico tende a ser regular. (GUY e ZILLES, 2007, p. 109) O corpus linguístico seria o conjunto de dados ou conjunto de ocorrências em sentido amplo, selecionadas e extraídas do acervo do pesquisador (GUY e ZILLES, 2007, p. 115). De forma geral, a questão da representatividade é um problema nas pesquisas variacionistas, porque frequentemente não se consegue selecionar representativamente os colaboradores para a composição das entrevistas.

A amostragem por cota ou julgamento é quando o objetivo é algum grupo específico, ou seja, quando o foco é algum grupo particular de falantes. Um exemplo é quando se quer estudar a fala urbana. Se a comunidade é determinada, não faz sentido, nesse caso, incluir falantes da zona rural. Assim, a amostragem não é aleatória, mas escolhida por motivos específicos.

Nessa amostragem, os entrevistados são quantificados em termos de cruzamento de fatores sociais. Assim, definem-se as categorias sociais e a quantidade de células sociais. Segundo Tarallo (2004, p. 30) e Guy e Zilles (2007, p. 112), a quantidade ideal é de 5 pessoas por combinação de fatores extralinguísticos para que se possa comparar os indivíduos entre si e descobrir possíveis idiossincrasias, uma vez que analisam-se fenômenos de fato variáveis, e não formas aleatórias e peculiares de cada membro da comunidade.

Guy e Zilles (2007, p. 112) explicam que, se temos apenas uma pessoa por célula, não há como saber se seu comportamento linguístico é idiossincrático ou enviesado. Se colocamos duas pessoas com as mesmas características, e o comportamento é semelhante, a tendência é explicarmos que se trata de pessoas de um mesmo grupo social. Se são diferentes, novamente não temos como confrontar esses indivíduos com outros, além de não sabermos se o comportamento é individual ou aleatório. Por isso, 4 ou 5 pessoas aumentam as chances de identificar tendências reais do uso linguístico.

Nessa pesquisa, as 38 entrevistas, de aproximadamente 40 minutos cada, foram analisadas e distribuídas entre duas nacionalidades, dois sexos e três faixas etárias. O grau de escolaridade foi apenas controlado.

A realidade da pesquisa de campo nos permitiu fazer a combinação de 5 a 7 colaboradores por faixa etária e nacionalidade, sem levar em consideração o equilíbrio do sexo dos colaboradores. Na célula de uruguaios de 31 a 49 anos, só há mulheres, mas o restante está mais equilibrado com relação ao quantitativo geral de colaboradores. A seguir, verifica-se a distribuição dos colaboradores em função da faixa etária, sexo e nacionalidade. 
Quadro 2: Distribuição dos 38 colaboradores brasileiros e uruguaios

\begin{tabular}{|c|l|l|}
\hline FAIXA ETÁRIA & \multicolumn{1}{|c|}{ Brasileiros } & \multicolumn{1}{c|}{ Uruguaios } \\
\hline 15 a 29 anos & 4 homens & 3 homens \\
& 3 mulheres & 4 mulheres \\
\hline 31 a 49 anos & 2 homens & 6 mulheres \\
& 5 mulheres & \\
\hline Acima de 50 anos & 3 homens & 2 homens \\
& 2 mulheres & 4 mulheres \\
\hline $\begin{array}{c}\text { TOTAL: 38 } \\
\text { colaboradores }\end{array}$ & 19 colaboradores & 19 colaboradores \\
\hline
\end{tabular}

No geral, são 19 colaboradores brasileiros e 19 colaboradores uruguaios, totalizando 38 pessoas. A categoria escolaridade também foi controlada, mas sem entrar na composição das células sociais, mesmo porque pulverizaria mais os falantes por célula e desequilibraria a amostra. Guy e Zilles (2007, p. 113) afirmam que

Nesse caso, quando queremos investigar mais dimensões sociais sem multiplicar espantosamente a amostra, contentamo-nos em ter um total razoável de cada categoria social, e uma distribuição razoável dos indivíduos que compõem esse total nas outras dimensões, sem que tal distribuição seja, necessariamente, perfeitamente, equilibrada, como seria na abordagem de manter o mesmo número de informantes em cada célula.

Como a constituição das entrevistas já é pequena, não consideramos escolaridade uma célula, por isso apenas controlamos esse fator social nos colaboradores que já foram estratificados segundo faixa etária, sexo e nacionalidade. Todavia, Guy e Zilles (2007, p. 114) afirmam que

Sem a distribuição complementar equilibrada das subamostras, perdemos um pouco da confiabilidade dos resultados, pelo fato de se reduzir a precisão da distinção feita nos resultados entre o efeito de uma dimensão (por ex., escolaridade) e outra (sexo). Mas o uso de métodos multivariados de análise, como o Varbrul, compensa um pouco esse problema, e ganhamos a vantagem de ter ampliado o escopo da investigação (para incluir sexo e escolaridade $^{72}$ ), com um mínimo de trabalho adicional.

O sexo já existe na composição dessa amostra, mas a escolaridade não entrou para a distribuição complementar da amostra porque, no município de Aceguá, o índice de analfabetismo é baixo, segundo informações da própria comunidade em entrevista, a partir de observações participantes nas escolas locais e do SIAB (Sistema de Informação da Atenção Básica) de 2009. A grande maioria das pessoas que deseja continuar os estudos tem de sair de lá, uma vez que a instituição de ensino superior (IES) mais

\footnotetext{
${ }^{72}$ A expressão entre parênteses (para incluir sexo e escolaridade) é acréscimo meu.
} 
próxima fica a $60 \mathrm{~km}$ de Aceguá. Assim, a população local é basicamente formada por moradores que possuem ensino fundamental e médio, ou seja, dois níveis de escolarização.

Para a concretização do trabalho e para que a pesquisa fosse aprovada, submetemos o projeto de doutorado ao Comitê de Ética e Pesquisa do Instituto de Ciências Humanas (CEP-IH) da Universidade de Brasília (ANEXO 2), que regula a ética da pesquisa com seres humanos. Quando a pesquisa foi autorizada pelo comitê, em 2011, começamos a investigação propriamente dita.

Logo, com essa preocupação social e ética, antes das entrevistas, os colaboradores leram o Termo de Consentimento Livre e Esclarecido - TCLE I (ANEXO 1) e ficaram cientes dos objetivos e benefícios da pesquisa, da duração da entrevista (no máximo de uma hora), da participação voluntária e consentida, da confidencialidade da identificação e de que não haveria riscos para os participantes da pesquisa. Depois do aceite, eles assinaram o documento, cientes também de que, a qualquer momento, poderiam desistir de participar, retirando seu consentimento. Cada um ficou com uma cópia que continha minha assinatura e meus dados pessoais (e-mail e celular).

Depois da aprovação do comitê de ética e da pesquisa de campo, constituíram-se a variável dependente, nós e a gente como primeira pessoa do plural, e as variáveis independentes linguísticas e sociais que serão descritas na seção seguinte.

\subsubsection{A variação de nós e a gente na fronteira}

No livro Nós falemo brasileiro (1987), especialmente na parte que versa sobre os fenômenos linguísticos que os autores Elizaincín, Behares e Barrios (1987, p. 85) encontraram no português uruguaio da década de 70, não há menção à alternância nós e a gente. Segundo os autores, o uso de a gente do lado uruguaio não tem o mesmo significado do português brasileiro, diferenciando-se da primeira pessoa do plural, além de o seu uso não ser sistemático e regular ${ }^{73}$.

En el uso de a gente observamos que no se tiende (como en P brasileño) a reemplazar sistemáticamente al pronombre "nos"; por el contrario, cuando aparece, conserva el sentido impersonal "estricto", diferenciádonse claramente de la cuarta persona. Por otro lado, solo la encontramos

\footnotetext{
${ }^{73}$ Fato semelhante foi descrito por Carvalho (2003b), ao constatar variação na pronúncia do $l h$, tanto como palatal lateral quanto semivogal, contrariando a afirmação de Rona (1965) de que a vocalização era categórica na fronteira.
} 
consignada en Vichadero/Minas de Corrales (V/MC) y Aceguá e Isidoro Noblía $^{74}$ (A/IN); aun en estas localidades no es sistemático su uso. (ELIZAINCÍN, BEHARES E BARRIOS, 1987, p. 85)

Para os autores, o pronome a gente não é utilizado como variante de nós, mas é encontrado em Aceguá, o que não quer dizer que ocorria nos dados dos autores de maneira variável. Na concepção de Elizaincín, Behares e Barrios (1987, p. 81-85), o pronome a gente era uma das diferentes formas de expressar impessoalidade nos Dialetos Portugueses do Uruguai (DPU).

Elizaincín, Behares e Barrios (1987, p. 13-14) descrevem o falar da fronteira como dialetos mistos de base preponderantemente portuguesa. Assim, as estruturas impessoais estariam relacionadas ora com o português, ora com o espanhol. Essa explicação é baseada em uma coleta de dados aleatórios sem o devido controle das variáveis linguísticas e sociais. Por isso, aparentemente, não se tem regularidade linguística. Os resultados são demonstrados com poucos dados e por meio de frequências relativas (apenas percentagens), sem uma maior sistematização da variação linguística. De qualquer forma, isso não os impediria de encontrar a gente como pronome alternado com nós, se fosse o caso.

Um exemplo dessa "mistura", a que os autores se referem, são as expressões impessoais utilizadas pelos falantes da fronteira, tais como o verbo haver e ter; os verbos fazer e dar; o sujeito genérico; a partícula se e os pronomes ou as expressões indefinidas (uno, a gente). Elizaincín (1992, p.135-136), em obra posterior, ainda acrescenta outras estruturas impessoais formadas pelos verbos fazer/hacer" " $f a z$ dois anos"; chamar/decir "A lechuga, que le chaman/ En Uruguay dicen de un cavalo".

No entanto, com uma pesquisa de campo mais criteriosa, levando em consideração a língua falada de ambas as comunidades, facilmente percebe-se que não se trata de "mistura" de línguas, porque os exemplos dos verbos haver, ter, fazer, dar, do sujeito genérico e da partícula se são todos variáveis na língua portuguesa.

A única forma espanhola (expressão indefinida uno) aparece em pouquíssimos dados de Elizaincín (1992) e do nosso corpus e, por isso, deveriam ser considerados casos de interferência gramatical, uma vez que não se trata de variação linguística entre as duas formas semelhantes, mas formas completamente distintas. Um exemplo típico

\footnotetext{
${ }^{74}$ As localidades por extenso foram acrescidas por mim. Os exemplos encontrados nessas localidades são: (i) A gente passa pelo ovo; (ii) A gente fica u charque; (iii) Se frita como a gente quiser. (Elizaincín, Behares, Barriso, 1987, p. 85). Os exemplos dos autores foram transcritos de acordo com a norma ortográfica vigente, e não com a norma fonética.

${ }^{75}$ Não há exemplos com o verbo hacer.
} 
do que se ouve muito em Aceguá é quando alguém pergunta o preço de algo e a pessoa responde que "dá unos quantos" ou a forma aportuguesada "dá uns quantos", o que de fato mostra a indeterminação do valor monetário em questão. Para o uso de "um" como pronome indefinido em Aceguá, tanto no português brasileiro quanto no português uruguaio, registramos pouquíssimos dados. Essa forma também é consequência direta do contato linguístico na fronteira.

Enquanto uno é indefinido, a gente se gramaticaliza e começa a ser utilizado como primeira pessoa do plural no português uruguaio. Em nossas entrevistas, há pouquíssimos dados com os verbos espanhóis haber, hacer, decir e outros, mas todos são considerados interferências e não misturas. As interferências, por sua vez, também podem ser sistematizadas e situadas contextualmente.

Como se pode notar em Elizaincín (1992, p. 81-85, 135-136), a gente é sempre vinculado à impessoalidade ou terceira pessoa do plural. De fato, no português brasileiro, há esse uso impessoal ou genérico, mas não se pode esquecer que a gente também ocorre em contextos de referência específica e, portanto, referência restrita a primeira pessoa do plural e até a primeira pessoa do singular. Os contextos de produção de cada variante fazem parte da análise variacionista, que controla os diversos tipos de ocorrências. Embora haja a conotação genérica de a gente, é importante observar que ainda há indícios de primeira pessoa do plural no a gente indeterminado.

Em suma, no caso do português, o uso de a gente como indefinido ou referência genérica ocupa a lacuna do sistema linguístico desde a evolução do latim, uma vez que passou a indicar indeterminação. Provavelmente, houve um estágio no português uruguaio e no português brasileiro em que o uso de a gente era apenas indefinido, depois passou a coexistir também como uso pronominal até chegar à mudança completa variando apenas com o pronome nós de primeira pessoa do plural. Atualmente, o a gente brasileiro também se propaga e se realiza no português uruguaio, mas a hipótese é que no português brasileiro a mudança estaria mais avançada do que no português uruguaio, em termos de frequência de uso do pronome.

Sobre a outra variante pronominal, Elizaincín (1992, p. 117-118) apenas menciona a existência do pronome nós e nosotros nos DPUs. Nas entrevistas com o português de Aceguá, o pronome nosotros não foi considerado dado de análise e, portanto, retirado da análise de pesos relativos, uma vez que se trata de uma interferência do espanhol, e não propriamente de alternância pronominal. 
Em seguida, o autor (1992, p. 136) constata a existência de a gente em variação com o nós, mas apenas no português brasileiro de uma forma geral, excluindo os DPUs:

El uso de "A gente" suele en $\mathrm{P}$ sustituir al pronombre nos, agregando este valor al de impersonalidad antes referido. No es este el caso en los DPU. Por otra parte, el recurso parece solo en dos localidades de la muestra: V-MC e A-IN. ${ }^{76}$

Em Aceguá, de fato, existe o uso pronominal de a gente, mas em Isidoro Noblía, outro bairro uruguaio, provavelmente não, porque, enquanto aquela é praticamente bilíngue, esta é basicamente monolíngue em espanhol. Como Elizaincín apresenta sempre os resultados em conjunto para Aceguá e Noblía, não há como saber realmente de onde foram retirados os poucos exemplos com A gente em primeira pessoa do plural.

No entanto, em praticamente todas as entrevistas que realizei do lado do Uruguai, há vários dados com o uso de a gente como primeira pessoa do plural, apesar de ser em menor proporção que o uso brasileiro. Ao que tudo indica, a entrada desse pronome é recente no português uruguaio e não se realiza em todas as funções sintáticas, sendo mais produtiva na posição de sujeito, como no exemplo a seguir:

Entrevistado: Isso aqui, a cultura é mais ou menos a mesma, de toda A
GENTE se confunde. Pra NÓS, $\emptyset^{77}$ NÃO NOTAMOS... vocês que vem de
longe podem notar a diferença, mas pra NÓS, A GENTE criou um dialeto
pra falar, A GENTE fala portunhol, $\varnothing$ NÃO FALA nem espanhol nem
português. Eu, por exemplo, hoje, não consego escrever nenhuma das duas
línguas de forma correta. Eu não escrevo nem português correto, nem
espanhol. Eu faço uma mistura, eu troco o C pelo Z, eu troco... NÓS no
espanhol não TEMOS Ç. (ALE, homem, acima de 50 anos, uruguaio, ensino médio)

Esse entrevistado é homem, uruguaio de Montevidéu, tem mais de 50 anos, e trabalha no Brasil. Sua mulher é uruguaia de Melo e trabalha no Uruguai. O casal afirmou que só conversa com os filhos em espanhol para não haver "mistura", porque eles são inseguros linguisticamente quanto ao uso do português. Entretanto, o casal de filhos também fala português e estuda na escola brasileira, porque os pais acham que a educação brasileira é melhor que a uruguaia.

O exemplo dessa família, como de tantas outras, apenas corrobora a integração total entre os dois lados da fronteira, e o quão os relacionamentos são imbricados. Além

\footnotetext{
${ }^{76}$ As localidades referidas são Vichadero e Minas de Corrales (V-MC), e Aceguá e Isidoro Noblía (AIN). Essa última é uma comunidade uruguaia e situa-se a $15 \mathrm{~km}$ de Aceguá-Uruguai. A abreviação "P" significa português.

${ }^{77} \mathrm{O}$ símbolo Ø representa a ausência do pronome de primeira pessoa do plural na função de sujeito.
} 
disso, os moradores, em maior ou menor grau, se conhecem, porque em alguns momentos de suas vidas estão unidos por laços familiares, de amizade, de trabalho.

Em termos linguísticos, identificamos apenas o primeiro exemplo (de toda $a$ gente se confunde) como impessoal, de acordo com o uso espanhol, principalmente porque há concordância de gênero entre o quantificador toda e o a gente em função de substantivo. Percebe-se, pois, que o sentido é genérico, de terceira pessoa do plural, podendo o exemplo ser reescrito como se fosse "a cultura de toda pessoa se confunde" ou "a cultura de qualquer pessoa se confunde".

Todavia, o falante, nos demais dados de a gente (A gente criou um dialeto pra falar/ A gente fala portunhol), se inclui nessa coletividade expressa pela primeira pessoa do plural ou quarta pessoa, da mesma forma que ocorre com os dados de implícito com nós (Pra NÓS, não Ø notamos...) e de implícito com a gente (A GENTE criou um dialeto pra falar, A GENTE fala portunhol, Ø NÃO FALA nem espanhol nem português). Nesses exemplos, é nítido que se trata de um fenômeno variável entre nós e a gente, que significa a extensão da inovação além das fronteiras nacionais.

Segundo Tagliamonte (2006, p. 96) "In the ideal situation you will find a 'super token': alternation of variants by the same speaker in the same stretch of discourse". Ou seja, em uma situação ideal, é importante encontrar um 'super dado': alternância de variantes pelo mesmo falante em uma mesma parte do discurso, o que acontece nesse exemplo, já que há dados de nós e a gente implícito e de nós e a gente explícito com o mesmo valor de verdade.

Assim, consequentemente, o português uruguaio e o português brasileiro dialogam entre si e manifestam a primeira pessoa do plural com as mesmas variantes linguísticas.

Sobre a definição de a gente, segundo Lopes (1996), as gramáticas tradicionais são controversas ao classificar a gente ora como pronome pessoal, ora como forma de tratamento, ora como pronome indefinido. Nessa pesquisa, considera-se a gente um pronome pessoal, porque é uma categoria pronominal, e não um sintagma nominal composto de determinante mais nome. A gente passou de nome que indica indeterminação a pronome de primeira pessoa do plural, fazendo parte do quadro pronominal do português brasileiro e, também, do português uruguaio. 


\subsubsection{A constituição da variável dependente e das variáveis independentes}

Ao encontrar a forma $a$ gente no português uruguaio, decidiu-se estudar a variável pronominal de primeira pessoa do plural para (i) registrá-la e descrevê-la no português uruguaio e no português brasileiro de Aceguá; (ii) estudar a mudança linguística como consequência do contato linguístico entre espanhol e português na fronteira; (iii) entender a tendência urbanizadora no português uruguaio com a inserção de uma variante prestigiada, sem estigma e urbana do português brasileiro.

A variante $a$ gente é urbana e os entrevistados também são de áreas mais urbanas de Aceguá. Essa variante também é de prestígio, porque é um pronome tipicamente brasileiro, ou seja, é prototípico de uma variedade monolíngue, almejada por muitos fronteiriços e, portanto, vista como de prestígio e até superior em relação à variedade que eles usam.

Logo, a variável dependente ou fenômeno linguístico investigado é a alternância entre os pronomes de primeira pessoa do plural - nós e a gente - conforme os seguintes exemplos.

\footnotetext{
Aqui o pessoal não tem, NÓS NÃO TEMO e aqui todo mundo tem lareira em casa, porque se não tiver uma lareira tu não soporta o inverno aqui.

(ROT, mulher, adulta, uruguaia, ensino médio)

Entrevistador: Se vocês puderem ficar né? Vocês foram em quantas pessoas? Entrevistado: Daqui de Aceguá A GENTE TAVA em três.
}

(ROT, mulher, adulta, uruguaia, ensino médio)

Antes de analisarmos as variáveis linguísticas e sociais, é importante também mencionar e exemplificar os dados que foram retirados da análise estatística, porque, de certa forma, não correspondem à variação entre nós e $a$ gente. Entre eles, estão os dados com:

- "Nosotros", "nuestro" e verbos em espanhol (20 dados)

Há apenas 4 dados de nosotros como transferência gramatical de primeira pessoa do plural no português falado pelos uruguaios, 2 dados do pronome possessivo "nuestro" e 14 dados de verbos em espanhol, como o exemplo de "tenemos". Todos esses dados foram produzidos pelos uruguaios em entrevistas na língua portuguesa. 
No caso desse fenômeno, não há "variação" com nosotros, mas apenas algumas interferências em contextos específicos. Por isso, não podemos dizer, como fizeram outros trabalhos, que se trata de uma "mistura" de línguas ou que há variação sem observação sistemática e regular dos dados. Nesses exemplos, o que ocorre é a interferência gramatical:

E me lembro quando era aquela época do Sarney, que tu tinha que remarcar mercadoria, perdón, a toda hora. E tu sabes que ni así, NOSOTROS DIZÍAMOS, um tempo se dizia que saudade do Sarney. Mas nós vendíamos, vendíamos, vendíamo horror. Não te preguntavam preço, sabes, vinham do Uruguai, pero.

(ESP, mulher, idosa, uruguaia, ensino médio)

Bueno, hoy TENEMOS la visita en NUESTRO programa [...], la visita vino de Brasília, nada más y nada menos que es de Cíntia da Silva Pacheco. Ella es estudiante de la Universidade de Brasília e está trabajando, realizando un trabajo aquí en esta frontera de Aceguá/Uruguai sobre una pesquisa, digamos que está siendo, de Doctorado, denominado El Português Fronteriço de Aceguá, Frontera Brasil/Uruguai. Vamos a darles las bienvenidas a Cintia e preguntarle ¿bueno cual es Cintia, cual es el objetivo de la pesquisa? ¿Buen dia, todo bien? ${ }^{78}$

(RAD, mulher, idosa, uruguaia, ensino médio)

No primeiro exemplo, o entrevistado alterna entre o código do português e o código do espanhol na mesma interação verbal (code-switching). Quando o colaborador diz "nosotros dizíamos", desconsideramos esse dado na análise estatística por ser uma interferência gramatical, e não propriamente variação linguística, no caso do nosso fenômeno em análise. Exemplos do tipo "NÓS VENDÍAMOS, VENDÍAMOS, VENDÍAMO” entram para a análise por se tratar da fala em português. Essa decisão é importante e é diferente do método de Elizaincín, que considerava indistintamente vários exemplos como variação linguística, como se fosse aleatória e não tivesse condicionamentos sociais e linguísticos, ou seja, sistematicidade.

No segundo exemplo, a fala é toda em espanhol com pronomes e verbos em espanhol, e, portanto, também foi desconsiderada da análise estatística, visto que o estudo é sobre o português uruguaio e o português fronteiriço de Aceguá, e não sobre o espanhol uruguaio.

\footnotetext{
${ }^{78}$ Essa entrevista foi concedida a radio Uruguaia em setembro de 2011. O objetivo era divulgar minha presença na comunidade em busca de entrevistas com moradores para uma pesquisa acadêmica. Em mais um exemplo de convivência harmônica entre as duas línguas, a radialista uruguaia entrevista sempre em espanhol e os entrevistados respondem ora em português, ora em espanhol. Essa rádio funciona em Aceguá, mas chega a ser ouvida em Bagé (a 60km).

Naquela ocasião, fui entrevistada em espanhol e respondi tudo em português, porque, durante toda a pesquisa de campo, procurei falar sempre em português para que os moradores se sentissem à vontade em também falar português comigo.
} 


\section{- A gente com sentido impessoal no português (13 dados)}

Nessa configuração, o pronome $a$ gente é utilizado como no português arcaico e espanhol, ou seja, sem marcar a primeira pessoa do plural. Nesse contexto discursivo, foram encontrados 10 dados de uruguaios e 3 dados de uma brasileira. Houve um exemplo falado por uma brasileira, que também utilizou empréstimos lexicais do espanhol (aunque e propia). A explicação pode ser o fato de ela ser casada com um uruguaio, além do contato constante e diário que todos têm com o espanhol da fronteira. O exemplo é o seguinte:

Entrevistada: ah sim. Aunque A GENTE não tem vida própia, como diz um.. Depende se vem os uruguaio. Se os uruguaio não vem, não funciona o comércio desse lado.

Entrevistador: é porque é pouca gente do lado de cá.

Entrevistada: e A GENTE que vem no freeshop, só VEM no freeshop.

(HIL, mulher, acima de 50 anos, brasileira, ensino médio)

Entrevistador: E aí tu aprendeu tudo na prática?

Entrevistado: Sim. Tudo o que sei aprendi, escutei, vi os outros falando, algumas palavras, que tipo, eles são, A GENTE aqui do Chicão, eles são de Iraí.

(FLO, mulher, 15 a 30 anos, uruguaia, ensino médio)

O primeiro dado de a gente (a gente não tem vida própia) é de primeira pessoa do plural e, portanto, foi considerado para nossa análise variável. Já o dado seguinte do mesmo exemplo (a gente que vem no freeshop, só vem no freeshop) se refere às pessoas que vêm de fora apenas comprar no freeshop de Aceguá. A brasileira não se inclui nessa coletividade, muito menos inclui os uruguaios e brasileiros de Aceguá, porque essa é uma prática típica de turistas.

No segundo exemplo, a mesma configuração de a gente com sentido impessoal, de terceira pessoa do plural, aparece na fala de uma uruguaia, quando diz que "a gente do Chicão são de Iraí". Novamente, a entrevistada não se inclui nessa coletividade, o que reforça a interpretação de a gente como sendo "as pessoas". A própria retomada anafórica recorrente nesses dados, como “eles são de Iraí”, é um traço linguístico claro de que se trata da terceira pessoa do plural.

Esses dados de a gente com sentido impessoal são interessantes, porque pode-se dizer que o contexto linguístico é semelhante tanto no português brasileiro da fronteira quanto no português uruguaio, conforme exemplos, ainda que tenha havido mais dados no português uruguaio. O resquício histórico e latino de impessoalidade está, pela pouca 
produtividade, em processo de mudança linguística quase completada nas duas comunidades. Essa seria uma semelhança estrutural e linguística dos dois lados da fronteira.

\section{- “La gente” com sentido impessoal no espanhol ( 2 dados)}

Em proporção menor que o a gente impessoal do português (13 dados), há apenas 2 dados de "la gente" no espanhol de um único colaborador uruguaio.

Carlos: pero que VAMOS a hacer, VAMO a produzir, VAMO poner LA GENTE a trabalhar con las extensiones de terra, con los roubo que hacen con lo que passa en Amazonas, con lo que roban na Amazonas.

(CAR, homem, acima de 50 anos, uruguaio, ensino médio)

Carlos: Vamos produzir, vamos fazer LA GENTE trabalhar. Agora, com a extensione de terra, com o roubo que fazem com le que passa com a Amazônia, com ló que roubam na Amazônia. Quanta gente legalmente podem trabalhar ali?

(CAR, homem, acima de 50 anos, uruguaio, ensino médio)

No primeiro exemplo, o colaborador alterna sua fala do português para o espanhol e utitiliza "la gente" como terceira pessoa do singular. No segundo exemplo, o mesmo colaborador volta a falar português, mas ainda mantém "la gente" do espanhol. É interessante notar que ambos os exemplos são similares, inclusive na estruturação sintática. Parece até ser uma tradução.

\section{- “Uno (un)" ou "um" com sentido impessoal do espanhol (3 dados)}

São 3 os dados de "uno" ou "un" como interferência gramatical do espanhol no português uruguaio e no português brasileiro de Aceguá. A palavra "uno" pode ser número cardinal, artigo ou pronome indefinido no espanhol. A palavra "Uno" perde o som-o se estiver antes de substantivo masculino. No caso desses exemplos, trata-se, de fato, do pronome indefinido.

Entrevistado: E tem, ali atrás que tá em construção é a junta, que eles chamam, junta local, que aí UM PODE ir ali falar qualquer coisa. Pode ir ali, mas tá em reforma, nem sei onde que tá o cara agora.

(MAU, homem, de 15 a 30 anos, uruguaio, ensino médio) 
Entrevistador: Ah, então é muito né?

Entrevistado: Dá UNS QUANTOS. E vocês vêem bastante mate. [sinônimo de "muito" ao se referir à quantidade de mate que eles consomem diariamente]

(ED, homem, de 15 a 30 anos, brasileiro, ensino superior)

A gente de fora, campanha tem medo de se abrir pra cualquiera, UNO NO CONHECE né.

(CAR, homem, acima de 50 anos, uruguaio, ensino médio)

Nos dois primeiros exemplos, o indefinido está em português (um ou uns) e, no terceiro exemplo, o pronome aparece em espanhol (uno), mas ambos com a mesma função sintática de indeterminação.

O registro do indefinido un/uno e da expressão a gente com sentido impessoal é um indício de que essa impessoalidade foi substituída pelo pronome a gente como primeira pessoa do plural no português brasileiro e se estendeu ao português uruguaio.

- Sintagmas nominais como sujeito explícito em primeira pessoa do plural, sem a presença dos pronomes nós ou a gente (4 dados)

Nesse caso, a primeira pessoa do plural não é expressa pelos pronomes nós e a gente, ou seja, o sujeito não é pronominalmente preenchido, por isso não entra na análise estatística. Exemplos:

\footnotetext{
Entrevistador: E vocês estavam lá hoje?

Entrevistado: Aqui. Eu tive oportunidade de ir a Santa Maria, estudar em Santa Maria, porque na época que eu estudava, na época eu era um excelente aluno, então eu ganhei pra estudar em Santa Maria, naquela época... na minha idade, eu to com 58 anos, eu estudei aqui e IA PRA SANTA MARIA EU E UMA PRIMA MINHA E OUTRO RAPAZ, inclusive eles foram e se formaram, eu não, aí NÓS era pobre e tal coisa, e tá, meu pai não podia me mandar, eu era guri, não fui em Santa Maria.
}

(MAN, homem, acima de 50 anos, brasileiro, ensino fundamental)

Desse tipo de exemplo, há apenas dois dados. Como se pode perceber, o sujeito posposto "Maria, eu e uma prima minha e outro rapaz" significa nós ou a gente, mas estão nomeados pelos substantivos e pelo pronome de primeira pessoa do singular.

\section{- Estrutura imperativa}

Nesses casos, o sujeito é sempre implícito e não se refere a nós ou a gente, mas sim a um comando genérico, impessoal. 
Entrevistada: Mas acontece que, acontece que, a criança ela não tem esse raciocínio que a gente tem né? O pensamento é muito concreto. Então a gente, olha, na escola a vista é maravilhosa, você enxerga isso de longe assim. VAMO SENTAR, VAMO OLHAR, eu boto todo mundo na frente, olha. Para esses que estão fazendo aula de reforço eu tive que mandar assim, vão descrever. Descreva o quarto, descreva a sala da casa de vocês, aprender o que é descrever né.

(FLA, mulher, adulta, brasileira, ensino superior)

Nos exemplos "Vamo sentar, vamo olhar", a interpretação não é "nós vamos sentar, nós vamos olhar", e sim ordenar com verbos no imperativo, que nada tem a ver com a alternância pronominal de primeira pessoa do plural, mas com a primeira pessoa do plural na forma imperativa.

Retirando os exemplos já mencionados, os dados submetidos ao programa estatístico foram os de primeira pessoa do plural, presentes tanto no português uruguaio como no português brasileiro. Assim, a variável dependente nós e a gente foi codificada em função de suas variáveis independentes sociais e linguísticas. Descrevemos no Quadro 3 as variáveis sociais, os fatores e as hipóteses que nortearam a coleta de dados. 
Quadro 3: Todas as variáveis sociais codificadas.

\begin{tabular}{|c|c|c|}
\hline Variáveis sociais & Fatores & Hipóteses \\
\hline Sexo & $\begin{array}{ll}\text { - } & \text { Mulher } \\
\text { - Homem }\end{array}$ & $\begin{array}{l}\text { As pesquisas sociolinguísticas têm } \\
\text { associado a mudança linguística ao } \\
\text { comportamento inovador das mulheres, } \\
\text { que, nesse caso, seria o uso do pronome } a \\
\text { gente em detrimento de nós. }\end{array}$ \\
\hline Faixa etária & $\begin{array}{l}\text { - } 15 \text { a } 30 \text { anos } \\
\text { - } 31 \text { a } 49 \text { anos } \\
\text { - } \quad \text { Acima de } 50 \\
\text { anos }\end{array}$ & $\begin{array}{l}\text { Estratificação etária em que é possível } \\
\text { detectar mudança linguística em tempo } \\
\text { aparente por meio de três faixas etárias. } \\
\text { Assim, quanto menor a faixa etária maior o } \\
\text { uso de a gente por se tratar de uma variante } \\
\text { inovadora. }\end{array}$ \\
\hline Nacionalidade & $\begin{array}{l}\text { - } \quad \text { Brasileira } \\
\text { - } \quad \text { Uruguaia }\end{array}$ & $\begin{array}{l}\text { A hipótese é que o pronome a gente seja } \\
\text { menos frequente no português uruguaio, jáa } \\
\text { que seu uso como primeira pessoa do plural } \\
\text { é típico do português brasileiro. } \\
\text { Essa variável é norteada pela nacionalidade } \\
\text { dos entrevistados e também pelo } \\
\text { conhecimento e uso do espanhol e do } \\
\text { português. Essas informações foram } \\
\text { resgatadas das entrevistas e agrupadas em } \\
\text { português brasileiro dos monolíngues } \\
\text { brasileiros e português uruguaio dos } \\
\text { bilíngues uruguaios. Muitos uruguaios } \\
\text { também têm dupla-nacionalidade e } \\
\text { geralmente falam português e espanhol, } \\
\text { mas foram enquadrados como apenas } \\
\text { uruguaios por essas características comuns } \\
\text { da comunidade uruguaia. }\end{array}$ \\
\hline Grau de escolaridade & $\begin{array}{ll}\text { - } & \text { Ensino } \\
& \text { fundamental } \\
\text { - Ensino médio } \\
\text { - Ensino superior }\end{array}$ & $\begin{array}{l}\text { Variável apenas de controle que não } \\
\text { compôs a divisão equilibrada das células. } \\
\text { Como esse fenômeno possivelmente não é } \\
\text { estigmatizado na fala (ZILLES, 2007, p. } \\
\text { 37), entende-se que a escolaridade não } \\
\text { exerce tanta influência para o uso de nós ou } \\
\text { a gente, ainda que o pronome nós seja mais } \\
\text { típico da língua escrita e, } \\
\text { consequentemente, do ensino formal. }\end{array}$ \\
\hline $\begin{array}{l}\text { Identificação do } \\
\text { colaborador }\end{array}$ & & $\begin{array}{l}\text { Variável de controle de cada colaborador } \\
\text { para análise do desempenho linguístico } \\
\text { individual e, posteriormente, coletivo. }\end{array}$ \\
\hline
\end{tabular}

A seguir, também descrevemos as variáveis linguísticas, os fatores e suas respectivas hipóteses. O mapeamento dos fatores que condicionam o uso de a gente ou nós é de fundamental importância para o entendimento e a explicação do fenômeno de primeira pessoa do plural.

Os contextos de realização de uma ou outra variante dependem de fatores linguísticos e extralinguísticos que condicionam seu uso, ou seja, do seu encaixamento linguístico e social. "Para entender a difusão das mudanças é preciso esclarecer seus 
condionamentos estruturais e sociais em cada ponto do espaço linguístico". (WEINREICH, LABOV e HERZOG, 2006, p. 26).

Quadro 4: Todas as variáveis linguísticas codificadas.

\begin{tabular}{|c|c|c|}
\hline $\begin{array}{l}\text { Variáveis } \\
\text { linguísticas }\end{array}$ & Fatores & Hipóteses \\
\hline $\begin{array}{l}\text { Preenchimento } \\
\text { do sujeito }\end{array}$ & $\begin{array}{l}\text { - Sujeito explícito } \\
\text { - Sujeito implícito }\end{array}$ & $\begin{array}{l}\text { O sujeito explícito favoreceria o } \\
\text { pronome a gente, uma vez que é difícil } \\
\text { recuperar esse pronome no contexto. Em } \\
\text { contrapartida, o sujeito implícito levaria } \\
\text { a uma maior realização do morfema } \\
\text { número-pessoal de plural nos verbos } \\
\text { para identificar a pessoa do discurso. }\end{array}$ \\
\hline $\begin{array}{l}\text { Função } \\
\text { sintática }\end{array}$ & $\begin{array}{l}\text { - Sujeito } \\
\text { - Objeto direto } \\
\text { - Objeto indireto } \\
\text { - Adjunto adverbial } \\
\text { - Adjunto adnominal } \\
\text { - Complemento nominal } \\
\text { - Aposto } \\
\text { - Tópico } \\
\text { - Termos intercalados ou } \\
\quad \text { isolados }\end{array}$ & $\begin{array}{l}\text { O avanço gradual de a gente pode se } \\
\text { estender a outros contextos sintáticos. } \\
\text { Indica em primeiro plano que a forma } a \\
\text { gente tende a ser mais frequente na } \\
\text { posição de sujeito. A hipótese, portanto, } \\
\text { é que no português uruguaio a variante } a \\
\text { gente seja mais restrita ao sujeito, já que } \\
\text { parece ser uma inovação recente nessa } \\
\text { variedade. Segundo Omena (1996, p. } \\
\text { 191), a função mais produtiva é a de } \\
\text { adjunto adverbial seguida do sujeito. }\end{array}$ \\
\hline $\begin{array}{l}\text { Tipo de } \\
\text { referência }\end{array}$ & $\begin{array}{ll}\text { - } & \text { Eu } \\
\text { - } & \text { Eu + Você } \\
\text { - } & \text { Eu + Você + Ele } \\
\text { - } & \text { Eu + ele } \\
\text { - } & \text { Genérico } \\
\text { - } & \text { Discurso reportado } \\
\end{array}$ & $\begin{array}{l}\text { A referência mais genérica tenderia a } \\
\text { favorecer o uso de a gente, enquanto a } \\
\text { referência mais específica tenderia a } \\
\text { favorecer o uso de nós. }\end{array}$ \\
\hline $\begin{array}{l}\text { Tempo verbal e } \\
\text { saliência fônica }\end{array}$ & $\begin{array}{ll}\text { - } & \text { Pretérito perfeito com } \\
& \text { neutralização } \\
\text { - } & \text { Pretérito perfeito sem } \\
& \text { neutralização } \\
\text { - } & \text { Presente com neutralização } \\
\text { - } & \text { Presente sem neutralização } \\
\text { - } & \text { Imperfeito do indicativo } \\
\text { - } & \text { Futuro do pretérito do } \\
& \text { indicativo } \\
\text { - } & \text { Imperfeito do sujuntivo } \\
\text { - } & \text { Presente do subjuntivo } \\
\text { - } & \text { Futuro do subjuntivo } \\
\text { - } & \text { Infinitivo } \\
\text { - } & \text { Gerúndio } \\
\end{array}$ & $\begin{array}{l}\text { A forma a gente favoreceria os tempos } \\
\text { presente e pretérito imperfeito para (i) } \\
\text { evitar proparoxítona (MATTOS, 2013); } \\
\text { (ii) evitar ambiguidade ou a neutralidade } \\
\text { do presente e pretérito e (iii) distinguir } \\
\text { especialização temporal (NARO et alii, } \\
1999 \text { e 2014). } \\
\text { A neutralização refere-se à mesma } \\
\text { forma para dois tempos verbais e dois } \\
\text { significados diferentes, ou seja, a } \\
\text { conjugação "cantamos" pode ser tanto } \\
\text { do presente quanto do pretérito, a } \\
\text { depender do contexto. Nesse caso, há } \\
\text { perda da oposição funcional o que } \\
\text { possibilita a ambiguidade. }\end{array}$ \\
\hline $\begin{array}{l}\text { Paralelismo } \\
\text { linguístico }\end{array}$ & $\begin{array}{ll}\text { - } & \text { Isolado } \\
\text { - } & \text { Primeiro da série } \\
\text { - Não primeiro da série } \\
\text { - } \\
\text { - Não primedio de nós explícito da série } \\
\text { - } \quad \text { Nãocedido de nós implícito } \\
\text { - }\end{array}$ & $\begin{array}{l}\text { Talvez a variável paralelismo linguístico } \\
\text { (SCHERRE, 1998) seja a mais } \\
\text { recorrente em qualquer fenômeno } \\
\text { variável. Como não poderia ser } \\
\text { diferente, no caso dos pronomes de } \\
\text { primeira pessoa do plural, a hipótese é } \\
\text { que "marcas levam a marcas e zeros }\end{array}$ \\
\hline
\end{tabular}




\begin{tabular}{|l|l|l|}
\hline $\begin{array}{l}\text { precedido de } a \text { gente } \\
\text { explícito }\end{array}$ & $\begin{array}{l}\text { levam a zeros" Dessa forma, as } \\
\text { ausências do pronome a gente ou nós } \\
\text { favorecem a ausência do pronome no } \\
\text { precedido de } a \text { gente } \\
\text { implícito }\end{array}$ & $\begin{array}{l}\text { dado posterior. Na mesma proporção, a } \\
\text { presença do pronome favoreceria a } \\
\text { presença do mesmo pronome nos dados } \\
\text { seguintes. }\end{array}$ \\
\hline
\end{tabular}

Para efeitos de comparação e de entendimento global da comunidade de Aceguá, fizemos três análises principais: uma análise com falantes brasileiros e uruguaios, considerando Aceguá como uma única comunidade linguística, tanto do lado do Brasil quanto do lado do Uruguai; uma análise apenas com falantes brasileiros; e uma análise apenas com falantes uruguaios. Desmembramos cada análise em dois grupos - um que inclui todos os dados e um que exclui os dados categóricos de nós. As hipóteses e exemplificações de cada fator também serão detalhadas no Capítulo 5. 
Para aqueles linguistas que estão interessados no estudo da linguagem em contexto social, uma das possibilidades mais intrigantes é a descoberta e análise da mudança em curso. Esta dimensão da variação linguística oferece um bom número de perspectivas para a explicação e verificação dos nossos modelos de estrutura da linguagem ${ }^{79}$.

(LABOV, 1981, p. 177)

Nesse capítulo sobre a análise variacionista, explicamos as variáveis linguísticas e sociais codificadas no programa Goldvarb-X e suas hipóteses para os pronomes nós e $a$ gente e, posteriormente, analisamos as 6 análises: (i) de brasileiros e uruguaios (com todos falantes e sem os casos categóricos de nós); (ii) de brasileiros (com todos os falantes e sem os casos categóricos de nós); (ii) de uruguaios (com todos os falantes e sem os casos categóricos de nós).

Começaremos com a hipótese principal que norteia o estudo, depois exemplificaremos os fatores, ilustraremos com as tabelas e/ou gráficos os resultados em percentagem e peso relativo e, por fim, faremos as explicações linguísticas e sociais preliminares. Os exemplos serão dados com a variante a gente e a variante nós, mas os resultados das variáveis serão mostrados em relação ao pronome a gente, pois este pronome é o responsável pela mudança linguística. Além disso, a expressão a gente é a variante inovadora no português uruguaio.

\subsection{Hipóteses e exemplos das variáveis sociais}

Para a seção das variáveis sociais, foi retirada da análise estatística a escolaridade, por ter sido apenas controlada, tendo em vista o desequilíbrio da amostra para essa variável, e a identificação do colaborador, utilizada para identificar todos os falantes e, possivelmente, os categóricos. As outras variáveis analisadas pelo Goldvarb$\mathrm{X}$ são sexo, faixa etária e nacionalidade. A seguir, explicamos as hipóteses iniciais que nortearam a codificação dessas variáveis.

\footnotetext{
${ }^{79}$ For those linguists who are interested in the study of language in its social context, one of the most intriguing possibilities is the discovery and analysis of change in progress. This dimension of linguistic variation offers a good many prospects for the explanation and verification of our models of language structure (LABOV, 1981, p. 177).
} 


\title{
5.1.1 Sexo
}

As pesquisas variacionistas têm associado a mudança linguística ao comportamento inovador das mulheres, que, nesse caso, seria o uso do pronome a gente em detrimento de nós. Para Labov (2008, p. 281, 282), é regular da estratificação social que as mulheres, sobretudo de classe média, utilizem menos formas estigmatizadas do que os homens quando se trata de fala monitorada. Assim,

\begin{abstract}
as mulheres são mais sensíveis do que os homens aos valores sociolinguísticos explícitos. Mesmo quando usam as formas mais extremas de uma variável sociolinguística em avanço em sua fala causal, as mulheres se corrigem mais nitidamente do que os homens nos contextos formais (LABOV, 2008, p. 281-282).
\end{abstract}

Nesse sentido, as mulheres tendem a usar variantes mais inovadoras, ou mais avançadas na fala informal e se corrigir mais na fala monitorada rumo às formas de prestígio. As mulheres são mais sensíveis aos padrões de prestígio e, por isso, desepenham importante papel na mudança linguística (LABOV, 2008, p. 345-349).

\begin{abstract}
$\mathrm{Na}$ medida em que os pais influenciam a língua inicial das crianças, as mulheres influenciam mais ainda; as mulheres certamente conversam mais do que os homens com as criancinhas e têm uma influência mais direta durante os anos em que as crianças estão formando regras linguísticas com maior rapidez e eficiência. Parece provável que o ritmo do progresso e a direção da mudança linguística devem muito à especial sensibilidade das mulheres a todo o processo (LABOV, 2008, p. 347).
\end{abstract}

Isso não quer dizer que as mulheres sempre lideram o curso da mudança linguística, mas que a diferenciação sexual da fala constantemente desempenha um papel essencial para a evolução linguística. Tudo isso também é governado por valores sociais convencionais envolvidos na diferenciação da fala de homens e mulheres, no sentido de que a sociedade espera uma postura expressiva que é socialmente mais apropriada para um sexo do que para outro (LABOV, 2008, p. 348).

Segundo outro texto de Labov (1981, p. 185), na maior parte das mudanças fonéticas, as mulheres estão na liderança. Nesse caso, há uma oposição nítida entre as novas mudanças em progresso com mulheres inovando, e os estágios mais antigos ou estáveis com mulheres mais conservadoras. Para as mudanças fonéticas que os homens lideram, não há esse contraste, mas para comunidades onde as mulheres favorecem o prestígio de marcadores estáveis, a variável que mostra as mulheres na liderança pode ser uma nova mudança em progresso. 
Scherre e Yacovenco (2011) propõem que o efeito do sexo é orientado pelo princípio da marcação de Givón (2005) e que o prestígio é apenas um dos aspectos da noção de marcação linguística e social.

\begin{abstract}
Em configurações menos marcadas - e não necessariamente mais prestigiadas - as mulheres estão à frente na variação ou na mudança" [...] em configurações mais marcadas - e não necessariamente menos prestigiadas os homens estão à frente na variação ou na mudança (SCHERRE e YACOVENCO, 2011, p. 139)
\end{abstract}

Essa interpretação mais complexa do sexo, envolvendo não só prestígio, mas também configurações menos marcadas, foi feita a partir de resultados de três fenômenos linguísticos: o tu como índice de identidade geográfica, o imperativo associado ao indicativo em amostras de diversas localidades brasileiras e a presença da concordância verbal.

Em Yacovenco e Scherre (2012), há a análise de alguns fenômenos variáveis da amostra do Português Falado na Cidade de Vitória/ES (Portvix) com base também no sexo. Dentre eles, aborda-se a alternância de nós e a gente a partir do estudo de Mendonça (2001) e Omena (2003). Nesses estudos, as mulheres favorecem o uso de $a$ gente.

Yacovenco e Scherre (2012, p. 178) relatam que, no projeto PEUL (Programa de Estudos sobre o Uso da Língua), Omena (2003) faz uma pesquisa em tempo real sobre duas amostras, de 1980 e 2000 . Nesse caso, a variação pronominal de nós e a gente foi interpretada como estável, sendo o pronome a gente preferencialmente usado por mulheres. Posteriormente, numa segunda análise com a amostra de 1980 e a recontatada de 2000 , Omena (2003, p. 80) conclui que mesmo com certa estabilidade o pronome $a$ gente vai ganhando terreno de forma lenta.

Ainda segundo Yacovenco e Scherre (2012, p. 179), a alternância pronominal de primeira pessoa do plural está abaixo da consciência social, avança de forma lenta e não está sujeita a estigma, adentrando inclusive na fala da mídia e na propaganda escrita.

Em contrapartida do maior uso de a gente pelas mulheres em áreas mais urbanas, como Vitória, Florianópolis e Porto Alegre, a variável sexo também possui uma diferença mínima ( 1 ponto) de peso referente ao uso de a gente por homens e mulheres, como em Pelotas e Jaguarão, cidades do interior do Rio Grande do Sul (YACOVENCO e SCHERRE, 2012, p. 180). Assim, mesmo sendo uma variável selecionada nas áreas interioranas, o efeito do sexo é neutro, na faixa de 0,51. 
Sobre a dicotomia sexo e gênero ${ }^{80}$, Guy e Zilles $(2006$, p. 111) também afirmam que é precária a noção de sexo ao contrapô-la à de gênero. Assim, para Labov (2001, p. 263), a codificação dos dados é relacionada ao sexo biológico, para não perder a comparabilidade dos resultados, mas a interpretação dos dados é de gênero como uma noção social e/ou cultural, já que o importante é a produção social dos papeis sociais de gênero e não o sexo biológico.

\subsubsection{Faixa etária}

No caso da alternância de primeira pessoa do plural nós e a gente, a hipótese é de que cada nova geração brasileira utilize cada vez mais o pronome a gente, mais produtivo e avançado no português brasileiro do que no português uruguaio.

A divisão etária em 15 a 30 anos, 31 a 49 anos e acima de 50 anos, foi pensada de duas formas: (i) a partir da história social e linguística da comunidade; (ii) conforme as faixas etárias tradicionalmente separadas nos trabalhos do português brasileiro para fins de comparação.

Assim, os jovens são da década de 80/90, os adultos da década de 60/70 e os acima de 50 anos da década de 50 para baixo. O pronome a gente, supostamente, existiria com mais força a partir da década de 90 com o favorecimento pelos jovens, porque até então não se tinha registro de a gente como pronome de primeira pessoa do plural no português uruguaio, conforme Elizaincín, Behares e Barrios (1987) afirmam a respeito da década de 70. Outro fato é que, segundo Zilles (2007, p. 35), ao citar seu estudo de 2005, a amostra do NURC de 1970 mostra que a variação de a gente não é significativa $(0,31)$ em comparação com a de 1990 na amostra do VARSUL $(0,67)$, ou seja, houve uma expansão desse uso apenas nas duas últimas décadas.

A hipótese, portanto, é que, de fato, os jovens favorecem mais a gente, uma vez que, provavelmente, faz pouco tempo que esse pronome entrou no português uruguaio e está se expandindo em mais uma comunidade como já vem acontecendo no português brasileiro de forma geral.

A estratificação etária em que é possível detectar mudança linguística em tempo aparente se distribui em três gerações. Assim, quanto menor a faixa etária maior o uso de $a$ gente por se tratar de uma variante inovadora. Portanto, os falantes de faixas etárias

\footnotetext{
${ }^{80}$ Essa distinção de sexo e gênero também é endossada por Dettoni, Pacheco, Andrade e Scherre (2012, p. 814).
} 
diversificadas têm um desempenho linguístico diferente, de modo que os mais jovens tendem a ser mais inovadores do que os falantes com mais idade, que tendem a ser conservadores. De acordo com Naro (2004, p. 43),

\begin{abstract}
os falantes mais velhos costumam preservar mais as formas antigas, o que pode acontecer também com as pessoas mais escolarizadas, ou das camadas da população que gozam de maior prestígio social, ou ainda de grupos sociais que sofrem pressão social normalizadora, a exemplo do sexo feminino de maneira geral, ou das pessoas que exercem atividades socioeconômicas que exigem uma boa apresentação para o público. E mesmo uma única pessoa pode escolher uma forma mais conservadora numa situação formal, preferindo outra forma mais atual em conversa informal.
\end{abstract}

A distribuição etária de mudança espontânea é ilustrada com o padrão curvilinear (curva $S$ ), que reflete o fato de os jovens utilizarem mais as variantes inovadoras. O paralelismo da curva $S$ indica que os sistemas linguísticos de falantes ficam estáveis durante a vida adulta. Cada falante estaria relativamente estável no uso da inovação durante a vida adulta, ou seja, o avanço da mudança ocorreria durante a adolescência ou nos primeiros anos de vida adulta. Esse uso linguístico na fase adulta se manteria até a idade mais avançada, uma vez que nessa faixa etária o conservadorismo prevalece.

Por isso, de acordo com Naro (2004, p. 45-46), a fala de uma pessoa de 60 anos representa a língua de 45 anos atrás e a fala de uma pessoa de 40 anos representa 25 anos atrás e assim por diante, ou seja, "o processo de mudança se espelha na fala das sucessivas faixas etárias". Esse seria o tempo aparente.

O tempo aparente é verificado em diferentes manifestações linguísticas em função das diferentes faixas etárias, como no caso da nossa pesquisa. Esse tempo, de certa forma, reflete o que aconteceu no tempo real desses falantes (LABOV, 1981, p. 178184). Em situação de mudança linguística em curso ou em progresso, a variante a gente é mais frequente em boa parte das variedades do português brasileiro e no português brasileiro da fronteira. Nosso trabalho também reflete o tempo real pelos registros anteriores de que não existia a gente como pronome de primeira pessoa do plural no português uruguaio, conforme afirmam Elizaincín, Behares e Barrios (1987, p. 85).

Sabe-se que a gente foi uma expressão que historicamente significava terceira pessoa e agora passou por um processo de gramaticalização, funcionando como pronome de primeira pessoa do plural. Estudando o momento sincrônico da coexistência de duas variantes (nós e a gente), é possível entender como essas formas linguísticas se comportavam diacronicamente, tendo em vista que ainda há resquícios 
históricos da indeterminação do pronome a gente. Nesse sentido, é fundamental acompanhar como as faixas etárias utilizam as variantes, porque são elas que simbolizam as gerações dos falantes e, consequentemente, a variação e mudança linguística ao longo do tempo.

\subsubsection{Nacionalidade}

Se o objetivo principal é estudar a entrada do pronome a gente no português uruguaio, foi necessário codificar essa variável em função dos colaboradores brasileiros e uruguaios na amostra.

A hipótese é que o pronome a gente seja menos frequente no português uruguaio dos bilíngues, já que seu uso como primeira pessoa do plural é típico do português brasileiro, conforme se pode ver nas pesquisas ilustradas na Tabela 1 (p. 119). A nacionalidade, nesse sentido, estaria vinculada ao grau de bilinguismo do colaborador. Normalmente, os uruguaios são bilíngues, ou seja, falantes de português e espanhol como língua materna, e os brasileiros são monolíngues, ou seja, falantes apenas de português como língua materna.

Para codificar um morador como sendo uruguaio, foram levados em consideração alguns fatores, tais como: a dupla nacionalidade ou nacionalidade uruguaia, o bilinguismo, a família dos dois lados da fronteira e o contato com brasileiros e uruguaios. Assim, a maioria dos uruguaios tem documentação brasileira e uruguaia, o que não significa dizer que ser uruguaio exclui ser brasileiro também. Por outro lado, os brasileiros normalmente não solicitam documentação uruguaia por, muitas vezes, nem ter familiares ou interesse, ou seja, o ato de solicitar a dupla nacionalidade também é uma forma de pertencimento ou de identidade múltipla.

A nacionalidade na fronteira é mesmo fluida no sentido de que há muitos doble chapa (dupla-nacionalidade), uruguaios que moram do lado brasileiro e brasileiros que moram do lado uruguaio, uruguaios casados com brasileiros. É possível haver namoros e casamento entre brasileiros e uruguaios, e, por isso, as famílias geralmente são compostas por ambas as nacionalidades. Sobre essa fluidez em aspectos socioculturais da fronteira e sobre as identidades múltiplas e pós-modernas dos fronteiriços, fazemos uma análise específica e mais qualitativa no capítulo 6 (p. 262).

Em entrevista com uma bilíngue uruguaia que trabalha no Censo do Uruguai, ela afirma que os uruguaios que moram no Brasil não são registrados no Censo do Uruguai. 
Já os brasileiros e outros estrangeiros que moram no Uruguai são registrados no Uruguai como estrangeiros. Assim, a nacionalidade fica em segundo plano para a administração pública, porque, para o Censo, é válido apenas o local onde a pessoa mora. Essa é uma realidade por que passa a zona fronteiriça Brasil-Uruguai.

Para tentar ser mais coerente com a realidade da fronteira, entendemos que o português brasileiro é falado por brasileiros, maioria monolíngue, naturais de Aceguá (lado do Brasil), e o português uruguaio é falado por uruguaios, maioria bilíngue, porque, se são uruguaios falando português, certamente também falam o espanhol, já que é a língua pública. Em nossas entrevistas, todos os uruguaios são bilíngues, mas há uruguaios na fronteira que falam apenas o espanhol, por isso não fazem parte da nossa pesquisa, uma vez que o pronome a gente como primeira pessoa do plural somente existe no português, e não no espanhol.

Neste trabalho, utilizamos as expressões "português uruguaio" para a variedade de português falada pelos uruguaios bilíngues da fronteira e "português brasileiro da fronteira" para o português falado pelos brasileiros da fronteira, em grande maioria monolíngues. Não se trata, pois, de duas línguas diferentes na fronteira, mas de duas variedades do português.

O tipo de bilinguismo de uruguaios e brasileiros não é o mesmo. Os brasileiros adquirem primeiro o português e depois, muitas vezes com mais idade, aprendem o espanhol pela convivência social e comercial e utilizam-no em contextos específicos. Normalmente, entre brasileiros não se fala espanhol. Já os uruguaios, que geralmente são bilíngues, adquirem o português e o espanhol como língua materna desde crianças e compartilham dessas duas línguas simultaneamente em diversos contextos sociais e familiares. Normalmente, mesmo entre uruguaios se fala português.

A semelhança do bilinguismo brasileiro e uruguaio é que ambos são sociais, pois os falantes vivenciam constantemente situações sociais que lhes permitem utilizar as duas línguas. A diferença é a motivação para o uso das línguas. Enquanto o português uruguaio é uma prática linguística cotidiana, o espanhol falado por brasileiros é uma prática linguística determinada por algumas situações sociais. Assim, o português uruguaio é habitual e recorrente na fronteira, enquanto o espanhol, quando falado por brasileiros, é mais específico e restrito a certos contextos linguísticos segundo nossas observações e entrevistas. 


\subsubsection{Grau de escolaridade}

Essa variável é apenas de controle, ou seja, não compôs a divisão equilibrada das células. Como esse fenômeno provavelmente não é estigmatizado na fala (ZILLES, 2007, p. 37), entende-se que a escolaridade não exerce tanta influência para o uso de nós ou a gente, ainda que o pronome nós seja mais típico da língua escrita e, consequentemente, do ensino formal.

A questão é que o pronome a gente pode estar entrando no português uruguaio com certo prestígio, já que representa uma inovação do português brasileiro monolíngue e urbano, ou seja, um dialeto desejável e, portanto, imitável, como descrito nos estudos de Carvalho (2003a, 2003b e 2008). No entanto, esse prestígio não é conscientemente atribuído pela escolaridade, mesmo porque o pronome a gente sequer é registrado na maioria das gramáticas tradicionais. O pronome a gente adquire certo status de prestígio por ser típico do português monolíngue brasileiro e por não ser uma inovação estigmatizada, mesmo porque, de acordo com Zilles (2007, p. 37), ocorre na fala de todo o país, chegando a quase $80 \%$.

Além disso, o principal motivo de não haver estratificação social que levasse em consideração os graus de escolaridade é que em Aceguá a maioria dos moradores tem nível fundamental e médio, porque na localidade não há Institutos de Ensino Superior. Quem continua os estudos geralmente sai da cidade. Por isso, a escolaridade não fez parte da constituição inicial das células, mas controlamos a codificação posteriormente com as entrevistas de que já dispúnhamos. Ao separar as análises do português brasileiro e do português uruguaio, a quantidade de dados diminui, e, novamente, essa variável social interfere negativamente nos resultados, porque os pulveriza ainda mais.

\subsubsection{Identificação do colaborador}

Essa variável mostra o desempenho linguístico individual e, posteriormente, coletivo da comunidade. A partir da identificação de cada um, é possível controlar prováveis efeitos categóricos e até mesmo fazer rearranjos ou agrupamentos sociais diversos, a depender da necessidade da pesquisa. Assim, tem-se um resultado mais preciso do desempenho linguístico individual.

Como codificamos outras variáveis sociais, tais como sexo, faixa etária e nacionalidade, ou rodamos a identificação do colaborador para os resultados estatísticos, 
ou rodamos as outras variáveis sociais, porque em um único colaborador já estão subentendidos todos os outros grupos sociais. Se rodamos os fatores sociais e a identificação do colaborador ao mesmo tempo, geralmente o Goldvarb-X acusa sobreposição de fatores sociais, o que pode enviesar os resultados. Como é importante analisar separadamente cada variável social, a identificação do colaborador é destinada a outras análises, até mesmo análises qualitativas acerca do comportamento individual dos colaboradores, especialmente as prováveis diferenças linguísticas e sociais de brasileiros e uruguaios (GUY e ZILLES, 2007, p. 47-70).

A codificação de cada colaborador permite verificar se se trata de variação linguística individual ou variação linguística na comunidade. De acordo com Sankoff (1988a, p. 992), é sempre bom substituir os fatores sociodemográficos por um único grupo de fatores, o falante, porque as categorias sociais não costumam ser tão "comportadas", ou seja, podem mostrar comportamentos mais individuais que coletivos. Foi a partir desses resultados que houve a necessidade de analisar melhor o idioleto de forma qualitativa e quantitativa.

Além disso, a importância crucial dessa variável social é que identificamos os colaboradores categóricos e os retiramos para a análise comparativa entre todos os dados e sem os dados categóricos. Diferenças sociais, sobretudo, foram identificadas e são detalhadas nas próximas seções de análise dos resultados, especialmente na seção 5.4 sobre a análise uruguaia, uma vez que sem os indivíduos categóricos se pode entender melhor o comportamento variável da comunidade.

\subsection{Hipóteses e exemplos das variáveis linguísticas}

As variáveis analisadas pelo Goldvarb-X são preenchimento do sujeito, paralelismo linguístico, tipo de referência e tempo verbal/saliência fônica. A seguir, explicamos as hipóteses iniciais que nortearam a codificação dessas variáveis.

Para a seção das variáveis linguísticas, foram retiradas a função sintática e a concordância de número. A primeira por não ter dado convergência na maior parte das análises, e, como a análise é comparativa de várias análises, foram necessários os mesmos critérios em cada uma delas. E a segunda, porque não há variação em todos os fatores, uma vez que apenas codificamos a distribuição possível de concordância de número associada aos pronomes de primeira pessoa do plural. No entanto, essas duas 
variáveis foram retiradas da análise de peso relativo, mas serão explicadas e exemplificadas em termos de frequência.

\subsubsection{Preenchimento do sujeito}

Segundo Ilari (2006, p. 106), o uso dos pronomes sujeitos era enfático na língua literária, mas tornou-se facultativo no latim vulgar. Hoje o pronome é obrigatório em algumas línguas românicas (francês, onde o pronome ficou intimamente ligado ao verbo, formando uma espécie de "conjugação prefixal") e omitido em outras (no caso do português).

A variável do tipo de preenchimento do sujeito foi codificada apenas para a função sintática de sujeito, ou seja, não se aplica às outras funções. A hipótese é que a presença do sujeito explícito favoreceria a gente, porque não se recupera esse pronome no contexto quando só há dados de sujeito implícito desde a primeira ocorrência, já que a concordância singular para a gente é a mesma da terceira pessoa do singular. Nesse sentido, quando o sujeito está implícito, haveria grande favorecimento ao pronome nós.

A codificação dessa variável leva em consideração que o sujeito implícito será relacionado com a gente ou nós dependendo do contexto anterior e posterior, ou seja, se há marcas no contexto de pronome a gente, o mesmo pronome será referência para o sujeito implícito. Nesse sentido, na codificação dos dados, há forte correlação da variável preenchimento do sujeito e da variável paralelismo linguístico, porque a interpretação de que pronome caberia no sujeito implícito implica o conhecimento da estrutura anterior e posterior do mesmo turno de fala, ou seja, no mesmo espaço e tempo em que ocorre a fala do colaborador em uma única interação verbal, sem a interrupção do pesquisador. A identificação dos pronomes que aparecem nos sujeitos explícitos do mesmo contexto discursivo facilita a interpretação dos sujeitos implícitos. Os exemplos de a gente e nós tanto de uruguaios como de brasileiros são:

- Sujeito explícito e sujeito implícito - A gente

A GENTE criou um dialeto pra falar, A GENTE fala portunhol, NÃO FALA NEM ESPANHOL NEM PORTUGUÊS.

(ALE, homem, acima de 50 anos, uruguaio, ensino médio) 
Entrevistadora: Hum. Mas esse curso você fez aqui mesmo?

Entrevistado: Aqui na receita, eu trabalhei direto né. Eu fiz o curso com eles também, é mais palestras, não é uma coisa... a teórica deles é na prática, a minha teórica era fazer um despacho, eu ganhando o dinheiro fazendo isso aí, entendeu? Então vem o cliente, A GENTE APRESENTA a mercadoria, LIBERA a mercadoria, e aí é a aprovação do fiscal, se ele carimbou tu ta aprovado. Se liberou o caminhão tá aprovado. Nós passamos 4 mil cabeças de gado aqui no tempo que eu trabalhei...

(EDI, homem, 31 a 49 anos, brasileiro, ensino superior)

\section{- Sujeito explícito e sujeito implícito - Nós}

NÓS TEMOS um clima semelhante ao do Rio Grande, pouquinha coisa mais frio, TEMO quatro estações bem definidas, mas TEMOS um povo que ascendeu a uma cultura média, geral, melhor do que a do brasileiro.

(ALE, homem, acima de 50 anos, uruguaio, ensino médio)

E eu vou ajudar ele a fazer. NÓS VAMOS fazer uns eventos em Bagé para ele e os eventos assim... eu já participei de um que fizeram para uma pessoa da comunidade ali, que fizeram uma festa e eu fui lá, me apresentei e cantei umas músicas, aí cada um vai, quem canta ou quem toca, quem dança, faz o que quiser, aí enche de gente, mas encheu de gente assim, aí tu vai e passa, passa as pessoas para juntar, arrecadar dinheiro do que tu tiver, do que tu puder dar. E aí NÓS CONSEGUIMOS para a guria que operou do tumor do cérebro, AJUDAMOS, não deu para pagar tudo, mas AJUDAMOS.

(EDI, homem, 31 a 49 anos, brasileiro, ensino superior)

Em sujeito implícito a gente de primeira posição, só há o correspondente a nós, porque no português de uma forma geral, pela redução do paradigma verbal, se o verbo aparecer no singular, vários seriam os candidatos além de a gente fala, tais como tu fala, ele fala, nós fala e eles fala (estes dois últimos exemplos de variedades estigmatizadas). Logo, não há dados de sujeito implícito singular na primeira posição.

Em sujeito implícito nós de primeira posição, o pronome nós será preenchido categoricamente em primeira posição caso a desinência seja plural, porque não há casos de a gente explícito com concordância plural nos dados de Aceguá.

Só não FESTEJAMOS a Epopeia Farroupilha, não TEMOS a Semana Farroupilha, não TIVEMOS. Mas o resto da NOSSA vida é bem semelhante a do gaúcho, hábitos alimentícios, costumes.

(ALE, homem, acima de 50 anos, uruguaio, ensino médio)

Nesse caso, todos os sujeitos estão implícitos, mas a referência é do pronome nós, na codificação da variável dependente, pela inexistência de exemplos de a gente com concordância plural, independentemente se aparecem os pronomes nós ou a gente em 
dados anteriores ou posteriores. Esse foi o critério utilizado para a codificação da variável preenchimento do sujeito.

Em sujeito implícito a gente de segunda ou demais posições, só há como saber quem é o sujeito analisando o contexto e os dados anteriores ou sucessores de determinado pronome. A interpretação desse sujeito segue, então, o princípio geral do paralelismo (POPLACK, 1979 e SCHERRE, 1988), em que marcas levam a marcas e zeros levam a zeros, ou, nesse caso, a presença de a gente leva à presença de a gente e a presença de nós leva à presença de nós.

No primeiro exemplo, a presença de a gente (A GENTE apresenta a mercadoria) ajuda a recuperar contextualmente o a gente implícito do dado seguinte (... LIBERA a mercadoria). Assim, o sujeito implícito do predicado "LIBERA a mercadoria" é recuperado pela estrutura anterior "A GENTE apresenta a mercadoria". O pronome $a$ gente será preenchido categoricamente em contexto singular e de segunda posição numa estrutura paralela caso tenha o mesmo pronome anteriormente em um dado próximo ou do mesmo turno de fala.

Em sujeito implícito nós de segunda ou demais posições, podemos interpretar os dados com nós, que também começam com sujeito explícito (NÓS vamos ... NÓS conseguimos), o que facilita a associação de nós em dados posteriores (AJUDAMOS ... AJUDAMOS). Mesmo que não houvesse o pronome explícito anteriormente, os dados com sujeito implícito (AJUDAMOS ... AJUDAMOS) seriam associados ao pronome nós, porque, ainda que em algumas regiões do Brasil seja possível a construção variável nós vamos ou a gente vamos, em Aceguá, não há nenhum dado com sujeito explícito $a$ gente e o morfema plural. Por isso, todos os dados com essa configuração foram interpretados como sendo do pronome nós. A construção a gente vamos também não existe em mais três comunidades bilíngues do Rio Grande do Sul: Flores da Cunha (italiano-português), Panambi (alemão-português), São Borja (espanhol-português), e uma comunidade monolíngue de Porto Alegre (ZILLES, 2007, p. 30).

Em contrapartida, o uso de nós com a concordância no singular ocorre na fronteira, o que dificulta a recuperação do sujeito quando o verbo está no singular e na segunda ou demais posições. Posto isso, a identificação do pronome se dá por meio das marcas no contexto. Se o dado anterior é nós, então o dado posterior implícito também será relacionado a nós, como no exemplo a seguir: 
Mas NÓS não, NÓS TEMO a televisão que desde pequeno, CRESCE, NASCE OIANDO TV, é diferente.

(JEF, homem, 15 a 30 anos, uruguaio, ensino médio)

Nesse exemplo, os sujeitos implícitos de "CRESCE, NASCE, OIANDO TV", mesmo estando no singular, foram codificados, na variável dependente, como nós por conta do sujeito explícito anterior "NÓS TEMO". Os mesmos dados posteriores também são levados em consideração para a análise.

Da mesma forma, se o dado imediatamente anterior é a gente, então o dado posterior implícito também será relacionado ao pronome a gente, como no seguinte exemplo:

...até pra NÓS é ruim por causa que A GENTE TRABALHA e PASSA corrida a Melo e PASSA corrida a Bagé (falando do horário de verão).

(MAN, homem, 15 a 30 anos, uruguaio, ensino médio)

Assim, os sujeitos implícitos "PASSA... e PASSA" foram codificados, na variável dependente, como a gente por conta do sujeito explícito anterior "A GENTE TRABALHA”.

No entanto, mesmo que tenha um a gente antes e o próximo dado seja implícito plural, consideramos a referência como nós por não existir a gente fomos, como no exemplo:

E eu sempre, principalmente para esses assim que eu to meio que trabalhando com reforço, num horário inverso, eu procuro fazer isso assim. Eu procuro não interferir não é na escrita espontânea. Depois assim, e peço para eles, olha, vocês primeiro assim, é a ideia. Aqui assim, o que A GENTE ESTÁ tentando é montar a ideia, então VAMO colocar a ideia. Depois assim, que a ideia está pronta, que eles fizeram assim a ideia, aí eu até ajudo eles, sublinho, ajudo.

(FLA, mulher, 31 a 49 anos, brasileira, ensino superior)

No exemplo "VAMO colocar", o sujeito é codificado como implícito, mas a variável dependente é codificada como nós, justamente porque não há exemplos de $a$ gente com a conjugação no plural de nós. Essa seria uma evidência linguística de que a inserção de a gente no português uruguaio pode ser realmente uma inovação na fronteira, o que significa também que esse pronome está menos encaixado linguisticamente do que em outras partes do Brasil.

O fato é que no Brasil há menos "a gente vamos" do que em Portugual (RUBIO, 2012, p. 18) e, em comunidades bilíngues do Rio Grande do Sul, menos ainda, haja 
vista que não foi encontrado nenhum exemplo em Aceguá (espanhol-português), Flores da Cunha (italiano-português), Panambi (alemão-português) e São Borja (espanholportuguês) (ZILLES, 2007, p. 30). Pode ser porque a expansão de a gente nessas construções ainda não tenha chegado à fronteira ou porque apenas essas entrevistas não contemplaram esse uso.

\subsubsection{Paralelismo linguístico}

No caso dos pronomes de primeira pessoa do plural, a hipótese é que "marcas levam a marcas e zeros levam a zeros" (POPLACK, 1979; SCHERRE, 1988 e 1998). Dessa forma, em um mesmo turno de fala, a presença de determinado pronome é diretamente proporcional à sua presença em dado posterior, ou seja, se um ou mais dados de primeira pessoa do plural são precedidos de a gente, os dados seguintes tendem a ser de a gente. O mesmo acontece com o pronome nós. A seguir, serão dados exemplos de nós e a gente na fala de uruguaios e brasileiros.

\section{- Isolado}

Quando o pronome está isolado no enunciado, ou seja, quando há apenas um dado em um mesmo turno de fala, a hipótese para esse fator é que haja certa neutralidade ou equilíbrio nos resultados, justamente porque não pode haver paralelismo com outros dados.

Entrevistadora: é mesmo. E lazer assim, coisas de final de semana, que que vocês costumam fazer.

Entrevistada: ah, A GENTE SAI bastante, mas aqui não tem muito lazer né. Aqui é muita...

(VAN, mulher, de 31 a 49 anos, uruguaia, ensino médio)

Entrevistador: São. Lá no auditório né, são boas.

Entrevistada: NÓS TEMO um teatro com a Josefa agora.

(VAN, mulher, de 31 a 49 anos, uruguaia, ensino médio)

Entrevistado: É 1 e meia eu vou chegar lá 2 horas, 2 e pouquinho, porque $\mathrm{A}$ GENTE demora uma meia hora daqui lá, não é muito perto. É perto, mas é caminho de chão e tem que ir devagar.

(MAN, homem, acima de 50 anos, brasileiro, ensino fundamental)

A não ser um dia que teve uma barreira que NÓS TEMOS de brigadianos, ou da polícia federal que haja algum roubo, que haja de alguma coisa, e ter má 
sorte que tu vai indo e encontre uma barreira aí na rua e que ta fazendo fiscalização.

(MAN, homem, acima de 50 anos, brasileiro, ensino fundamental)

- (a) Primeiro da série ${ }^{81}$ / (b) Não primeiro da série precedido de a gente explícito/ (c) Não primeiro da série precedido de a gente implícito

Maria Elena: Na escola, é. E que A GENTE morando assim APRENDE. APRENDE.

(MAR, mulher, de 31 a 49 anos, uruguaia, ensino médio)

Entrevistado: Porque (a)A GENTE SAI da ponte da amizade, ali uma quadra, mais ou menos, tinha a alfândega brasileira, (b) A GENTE chegava ali, (b) PAGAVA 50\% sobre o valor da mercadoria e (c) VINHA embora ou (c) IA para qualquer lugar do Brasil, e o resto (c) TRAZIA de contrabando, o que dava para chegar aqui chegava, o que não dava... pra todo lugar do Brasil. Ali tinha ônibus do Rio, de Brasília, de tudo que é lugar.

(PII, homem, acima de 50 anos, brasileiro, ensino fundamental)

- (a) Primeiro da série/ (b) Não primeiro da série precedido de nós explícito/ (c) Não primeiro da série precedido de nós implícito.

Era um lixão aquilo. (a) NÓS do Rotary ÍAMO lá, (b) JUNTÁVAMO o lixo, (c) MOVIMENTÁVAMO.

(ROT, mulher, de 31 a 49 anos, uruguaia, ensino médio)

Então eu já fico com ele [inint]. O dia do baile das prenda eu fui com a minha ermã, com essa que tava aqui. O marido dela não tava. E (a) NÓS VAMO lá, (b)VAMO VER, daí ela me convidou pra ir, tá (c)VAMO.

(HIL, mulher, acima de 50 anos, brasileira, ensino médio)

Os exemplos conjugados de Primeiro da série/ Não primeiro da série precedido de nós (ou a gente) explícito/ Não primeiro da série precedido de nós (ou a gente) implícito são apenas para ilustrar de uma só vez esses seis dados possíveis. Claro que há sequências de outras formas, mas todos os exemplos foram contemplados nesses fatores.

\footnotetext{
${ }^{81}$ Quando é o primeiro dado de uma sequência de dados posteriores de primeira pessoa do plural.
} 


\subsubsection{Função sintática}

A hipótese é que o aumento gradual de a gente estaria mais avançado em mais funções sintáticas no português brasileiro do que no português uruguaio, tendo em vista que se trata de uma mudança linguística recente. Assim, no português uruguaio seria mais comum encontrar o pronome a gente em contexto de sujeito, porque a função de sujeito é mais produtiva na língua e geralmente favorece a entrada das variantes inovadoras.

As formas pronominais retas são os pronomes usados como sujeito de um verbo. A forma oblíqua adverbial (nos) é usada como forma dependente junto ao verbo para expressar um complemento, que fonologicamente é uma partícula proclítica ou enclítica do verbo. Outra forma oblíqua é a de partículas subordinadas à preposição. Fonologicamente, são partículas tônicas, ocorrendo em posição proclítica à preposição subordinante (conosco). A diferença entre a forma reta nós e a forma oblíqua adverbial conosco é que esta, como partícula átona, perde a vogal média aberta, do quadro das vogais tônicas e fica com um $u$ do quadro vocálico átono final (CAMARA JR. 2004, p. 117-118). Como exemplos gerais da função sintática no português tanto uruguaio como brasileiro da fronteira, temos:

\section{- Sujeito}

Claro, porque as possibilidade deles continuarem e de fazer uma faculdade, pra NÓS AQUI, pela situação geográfica que A GENTE tá, vai ser no Brasil

(ALE, homem, acima de 50 anos, uruguaio, ensino médio)

Aí então A GENTE organiza tudo, então eu vou fazer parte como vicepresidente da chapa, possivelmente, provavelmente seje NÓS que ganhamos esse ano.

(EDI, homem, 31 a 49 anos, brasileiro, ensino superior)

- Objeto direto (nós e a gente) $)^{82}$

A gente fechou e Tava saindo na esquina e eles assaltaram NÓS na esquina, um carro.

(LIS, mulher, 15 a 30 anos, brasileira, ensino médio)

\footnotetext{
${ }^{82}$ Não há dado de a gente na função de objeto direto e não há nenhum dado de uruguaio.
} 


\section{- Objeto direto (nos)}

Temo o cavalo de fora, que tem gente que NOS PAGA.

(JEF, homem, de 15 a 30 anos, uruguaio, ensino médio)

Argentino ele saiu pra fora da Argentina, a primeira coisa que ele quer é um artesanato pra levar. E aí eles vieram pra cá, já conheciam a fama do cara e deu movimento, aí o cara foi embora e eles ficaram. Aí eles NOS ensinaram.

(JOS, homem, 15 a 30 anos, brasileiro, ensino médio)

\section{- Objeto indireto (para/pra nós e para/pra gente)}

Isso é pura gente de baixo nível, gente que tá pra outra coisa, gente que não tem nenhum tipo de cultura, entende? Se tu quer algo interessante, pra tu levar uma coisa que preste PRA GENTE.

(CAR, homem, acima de 50 anos, uruguaio, ensino médio)

Mesmo porque antes da abertura dos Free Shop, tinha um convênio, os policiais aqui do Uruguai faziam, aí no Clube, na Tropilla, reunia a comunidade dos vizinhos pra ver as inquietações que nós tínhamos com respeito a abertura do Free Shop, que não trazia segurança prA NÓS.

(ROT, mulher, 31 a 49 anos, uruguaia, ensino médio)

Não, isso aí é uma coisa a se pensar, uma emenda, não adianta fazer uma emenda de um deputado de 10 mil, 20 mil, você pensa em 100 mil já, eles falam prA GENTE.

(EDI, homem, 31 a 49 anos, brasileiro, ensino superior)

É, esse era uma chapinha assim e ele explicou pra NÓS, tu coloca sal pra ela não grudar em baixo, um pouquinho de sal e frita ela, mas é muito bom.

(LIS, mulher, 15 a 30 anos, brasileira, ensino médio)

\section{- Objeto indireto (nos)}

Você não sabe, está o ENEM aí pra NOS PROVAR, viste o ENEM aí NOS PROVOU.

(ESP, mulher, acima de 50 anos, uruguaia, ensino médio)

Filho - Entrevistado: Que até hoje tão brigando na justiça pra receber de Bagé o que NOS pertence.

(JOS, homem, de 15 a 30 anos, brasileiro, ensino médio)

\section{- Adjunto adverbial (com nós e com a gente)}

Então, o cavalo é domado, quando ele é amansado, a gente pega ele potro, acostuma ele com A GENTE.

(ALE, homem, acima de 50 anos, uruguaio, ensino médio)

Não. No caso tem a ..., que é a senhora que trabalha aqui COM NÓS, ela é brasileira.

(FLO, mulher, 15 a 30 anos, uruguaia, ensino médio) 
Entrevistador: Ué, mas ele foi de carro sozinho? Entrevistado: Não, foi com A GENTE.

(EDU, homem, 15 a 30 anos, brasileiro, ensino médio )

Porque quando ela está conversando assim com NÓS, e tá falando espanhol, $\operatorname{assim} .$.

(LEO, homem, de 31 a 49 anos, brasileiro, ensino médio)

\section{- Adjunto adverbial (conosco)}

Claro, ele vai falar contigo com muito gosto. Vai entrar lá em casa, conversa CONOSCO.

(RAD, mulher, acima de 50, uruguaia, ensino médio)

Eu fiz uma semana 43 horas normal e 42 horas extra. Pegava 7 hora e largava lá pelas 11 horas da noite quando o gerente ia embora, que era meu amigo, criado aqui junto CONOSCO.

(PII, homem, acima de 50 anos, brasileiro, ensino médio)

\section{- Adjunto adnominal (nosso, da gente)}

Porque sei lá, é o único jeito dA GENTE estudar né.

(VAL, mulher, de 15 a 30 anos, uruguaia, ensino média)

Temo o cavalo NOSSO e temo o cavalo de fora.

(JEF, homem, de 15 a 30 anos, uruguaio, ensino médio)

No caminho quando tu vê tiram a bolsa DA GENTE.

(MAR, mulher, acima de 50 anos, brasileira, ensino médio)

Carmen: É curso superior, é nível terciário, diz o NOSSO coisa... mas, assim, eu sou Mestra em Educação Comum e Mestra em Educação Inicial, para trabalhar com três, quatro e cinco anos também.

(CAR, mulher, de 31 a 49 anos, brasileira, ensino superior)

- Adjunto adnominal (de nós, que nós) ${ }^{83}$

Leonel: Tá. Então aqui, por exemplo, no Uruguai, hoje em dia no Uruguai, vamos dizer que, do México pra baixo, as pessoa lá, como por exemplo, os mexicano, a mesma coisa que NÓS aqui, que foram colonizados pelos espanhol, e os que foram colonizados pelos portugueses, aqui no caso do Brasil, eles dizem aqui, houve o que foi uma invasão. Entendesse?

(LEO, de 31 a 49 anos, brasileiro, ensino médio)

Leonel: De cada região tu vê que tem uma história diferente não é? Tu vê, lá te falam em Brasília, por exemplo, aqui, sobre a fronteira, de NÓS.

(LEO, de 31 a 49 anos, brasileiro, ensino médio)

\footnotetext{
${ }^{83}$ Não existe dado de $a$ gente nessa função de adjunto adnominal (*de gente, *que gente). E não há dados de nós nessa função na fala dos uruguaios.
} 


\section{- Tópico ou repetição do pronome ${ }^{84}$}

Isto aqui é uma Campanha, A GENTE, isso aqui é uma Campanha, então A GENTE, A GENTE DE FORA, campanha tem medo de se abrir pra cualquiera, uno no conhece né.

(CAR, homem, acima de 50 anos, uruguaio, ensino médio)

Carlos: NÓS aqui, nosso, um dos maior problema, em primeiro lugar é eso, a saúde, entendes.

(CAR, homem, acima de 50 anos, uruguaio, ensino médio)

A única coisa que tem, que existe lá, sabe o que é? Por exemplo, NÓS, que nós no semo ricos, o que tu vai procurar? Tu vai procurar coisa barata, lanche, tu vai buscar os meios que tu possa ir levando, e passar bem.

(LEO, homem, de 31 a 49 anos, brasileiro, ensino médio)

\section{- Complemento nominal ${ }^{85}$}

E eu não entendi o que ele falava ali. Ele fala totalmente diferente de NÓS. A senhora não fala.

(JOS, homem, de 15 a 30 anos, brasileiro, ensino médio)

Há cinco anos atrás, um terreno ali valia, de frente pra NÓS, ali de onde nós temo ali, te valia três ou quatro mil dólar. Chegaram a pagar quinhentos mil agora.

(LEO, homem, de 31 a 49 anos, brasileiro, ensino médio)

O quanto elas se misturam e o quanto isso tá presente em cada... Em cada um de NÓS né.

(MAR, mulher, de 31 a 49 anos, brasileira, ensino superior)

- Aposto $^{86}$

Lógico, todas as fronteira estavam indo. Estava Livramento, Quaraí, e também o Chuí, NÓS, Jaguarão, as fronteira.

(ROT, mulher, de 31 a 49 anos, uruguaia, ensino médio)

A gente acampa, são... eram 12 piquetes, ranchos assim de palha de Santa Fé, então aquilo é seco, então se pegar um isqueiro e tocar ali pega fogo em tudo em questão de segundos. Então aí diziam "o que,esses guri vão botar, vão tomar um trago aí e vão botar fogo em tudo", e aí A gente deu contra a todos eles, incendiou o rancho da brigada, da brigada militar que tava do nosso lado, o fogo do fogão a lenha, fogão de barro que sai ali, pegou uma chispa ali e começou a pegar fogo, e quem apagou foram os guri, NÓS do piquete, que diziam que a gente ia botar fogo em tudo.

(EDI, homem, de 31 a 49 anos, brasileiro, ensino superior)

\footnotetext{
${ }^{84}$ Não há dado de a gente na função de tópico na fala dos brasileiros.

${ }^{85}$ Não há nenhum dado de a gente como complemento nominal na fala de brasileiro e uruguaio, apenas esses três exemplos de nós na fala de brasileiro.

${ }^{86}$ Não há nenhum dado de a gente como aposto na fala de brasileiros e uruguaios, apenas esses dois exemplos de nós.
} 
Lógico, todas as fronteira estavam indo. Estava Livramento, Quaraí, e também o Chuí, NÓS, Jaguarão, as fronteira.

(ROT, mulher, de 31 a 49 anos, uruguaia, ensino médio)

\section{- Termo intercalado ou isolado em resposta única}

Por exemplo, tá, como A GENTE, eu sou do Rotary, trabalho no Rotary né.

(ROT, mulher, de 31 a 49 anos, uruguaia, ensino médio)

Não, NÓS, eu nasci lá, mas acho que eu teria uns 3 anos quando nós viemos embora pra qui, pra vila.

(VAN, mulher, de 31 a 49 anos uruguaia, ensino médio)

Entrevistado: É, porque a cidade grande A GENTE...

(PII, homem, acima de 50 anos, brasileiro, ensino fundamental)

Sim, NÓS aqui não, nessa escola não, mas tem escolas que invés de ter português tem inglês.

(CAR, mulher, de 15 a 30 anos, brasileira, ensino superior)

Omena (1996) relata que o caminho da mudança linguística do pronome a gente se dá também pela função sintática. "As divergências na frequência do uso de a gente (em oposição a nós), com relação à função sintática, refletem os diferentes estágios dessa mudança”. No geral, "a entrada de a gente é maior na função de adjunto adverbial, depois na de sujeito e complemento, que se equivalem. Está começando, porém, a atingir o uso do possessivo na função adnominal, onde ainda predomina uso de nosso". (OMENA, 1996, p. 191). Em verdade, os resultados de Omena, no conjunto, evidenciam de forma bem clara que há uma função sintática de resistência, que é a de adjunto adnominal, embora a função de adjunto adverbial seja a de efeito mais forte.

Nesse trabalho, a hipótese é que a gente ocorra mais na função de sujeito, já que os dados nessa função sintática são mais produtivos no português uruguaio e no português brasileiro do presente corpus, além de o pronome sujeito estar menos encaixado na sentença. Talvez a mudança linguística do pronome a gente ainda não tenha se expandido para funções mais encaixadas na fronteira.

Como a análise com as funções sintáticas amalgamadas (sujeito $\mathrm{x}$ outras funções) não deu convergência, optou-se pela análise de pesos relativos apenas com os pronomes em função de sujeito. Ainda assim, a função sintática será analisada em termos de percentagem, até porque vários fatores são categóricos para nós. 


\subsubsection{Tipo de referência}

Para o tipo de referência, o objetivo era identificar qual a motivação semântica ligada ao tipo de referência, genérica ou específica, que estaria interferindo na realização de nós ou a gente. A hipótese principal é que a referência específica favoreceria o pronome nós, enquanto a referência genérica favoreceria o pronome $a$ gente. Para Omena (2003, p. 68),

\footnotetext{
o que desencadeia a variação entre nós / a gente é o acréscimo do traço de primeira pessoa ao $\mathrm{SN}$ que estava passando de substantivo coletivo a pronome. Presentemente, são ainda os traços semânticos de número e indeterminação conservados na forma gramaticalizada, que apresentam sinais de mudança.
}

Portanto, a inserção de a gente no português como pronome de primeira pessoa do plural reflete uma mudança linguística que já vem sendo implementada desde o século XVIII no Brasil e confirmada na comunidade do Rio de Janeiro nas décadas de 1980 e 2000 (OMENA, 2003, p. 80).

Lopes (2003b, p. 54) propõe uma hierarquia quanto a grau de referenciabilidade (referencial/específico > genérico > impessoal/indefinido). No caso da fronteira, o pronome a gente no espanhol seria o impessoal, como já foi também no português arcaico. O a gente genérico ou indeterminado seria o pronome referente a outras pessoas, mas que não se sabe exatamente quem. $\mathrm{O}$ a gente mais referencial seria o mais específico, que vai de um continuum de "eu + uma pessoa específica" até a especificação máxima de a gente com referência a "eu”. Esse último dado, na verdade, não varia com nós, mas sim com "eu”, pronome de primeira pessoa do singular. Além disso, pode ser uma estratégia de esquiva para ocultar a primeira pessoa do singular, ou seja, uma forma de generalizar e não de especificar. Posto isso, esses dados foram retirados da análise de peso relativo.

Em suma, o uso da referência específica equivale à definição, especificação, individualização e determinação por meio de artigos definidos, possessivos, demonstrativos, pronomes pessoais e os nomes próprios. Já o uso genérico, nãoespecífico, não tem referência definida. Como diacronicamente o pronome a gente significou indeterminação, e ainda significa em outras línguas como o espanhol, a hipótese é que esse resquício histórico da referência genérica favorecesse o pronome $a$ gente. 
Neves (2000, 2008 e 2009) registra o uso alternado entre nós e a gente, incluindo a gente na linguagem coloquial ${ }^{87}$, e descreve o uso do pronome pessoal para: (i) referência à primeira pessoa do plural (= nós) e para referência genérica (incluindo todas as pessoas do discurso); (ii) indeterminação parcial do sujeito, assim como os sintagmas o cara, o cidadão, o pessoal e a pessoa. A diferença é que esses sintagmas não são considerados pronome como a gente (NEVES, 2000, p. 460-461, 465, 469470).

Em uma obra posterior, Neves (2008, p. 515) reafirma que a expressão a gente é originária de expressões lexicais de $3^{\text {a }}$ pessoa. Por isso, há resquícios da sua origem: (i) leva o verbo para $3^{\mathrm{a}}$ pessoa quando desempenha papel de sujeito; (ii) pode desempenhar o papel de objeto direto sem sofrer alteração de forma e sem exigir a preposição $a$ como no exemplo "Essa decisão prejudicou vocêla gente".

A expressão a gente pode chegar a um grau de indeterminação que resvala para a própria dispensa da referência à primeira pessoa (a gente = pessoas) (NEVES, 2008, p. 531). Esse uso linguístico diacrônico é o utilizado atualmente pelo espanhol ( $L a$ vida de la gente). No português brasileiro e no português uruguaio, o uso do pronome a gente com referência mais genérica varia com a referência mais específica, mas não deixa de incluir o falante + outra pessoa, ou seja, é de fato pronome de primeira pessoa do plural, mesmo porque ter a referência genérica é diferente de ser propriamente indeterminado, como ocorre no espanhol. Já a referência específica relacionada a "eu" refere-se ao extremo da particularidade e especialização do pronome a gente, deixando até de ser pronome de primeira pessoa do plural nesses casos.

Já o pronome nós como eu é explicado pela gramática (CUNHA e CINTRA, 2004, p. 283) como um plural de modéstia que evita o tom impositivo ou muito pessoal das opiniões. Geralmente, escritores e oradores usam nós no lugar de eu, dando a impressão de que as ideias são compartilhadas pelos leitores e ouvintes, uma vez que a conotação é coletiva.

$\mathrm{Na}$ codificação do tipo de referência, a hipótese é que a referência mais genérica favoreceria o uso de a gente, enquanto a referência mais específica favoreceria o uso de nós, já que há delimitação dos participantes envolvidos nessa coletividade (Eu, Você, Ele). Para Neves (2000, p. 459-460), “os pronomes plurais de primeira pessoa (NÓS, NOS) nunca se referem apenas à primeira pessoa, isto é, sempre envolvem um não-eu",

\footnotetext{
${ }^{87}$ Ainda segundo Neves (2008, p. 512), o pronome a gente é uma criação vernacular.
} 
uma vez que podem representar primeira pessoa com segunda (eu+tu ou você), primeira pessoa com terceira (eu + ele(s) ou ela(s)) e primeira pessoa com segunda e com terceira (eu $+\mathrm{tu} /$ você+eles e elas).

Assim, a expansão de a gente começaria nos contextos mais genéricos até os mais específicos, a ponto de variar também com a primeira pessoa do singular. A escala seria (genérico ou indeterminado > específico ou determinado > "eu"). A seguir, seguem alguns exemplos de a gente e nós na fala de uruguaios e brasileiros.

\section{- Referência genérica}

A referência genérica é por onde o a gente mais se espraia, a diversas pessoas, sem determinação contextual de quem são as pessoas do discurso, ou seja, nesse exemplo, é uma referência a todos os moradores de Aceguá. As expressões a gente do português e la gente do espanhol carregam o traço comum de indefinido, pois o pronome brasileiro tem uma interpretação genérica em algumas situações, como o exemplo a seguir, em que $a$ gente significa todos da fronteira, sem nenhuma especificação.

O trânsito. E A GENTE aqui não tem trânsito né. Hoje mesmo eu saí com um chimarrão, eu vou guiando e tomando chimarrão.

(ALE, homem, acima de 50 anos, uruguaio, ensino médio)

E tu vê que toda a população do Uruguai é menor do que a população de Porto Alegre né. NÓS somos três milhões e meio de habitantes.

(ALE, homem, acima de 50 anos, uruguaio, ensino médio)

Em Aceguá tem o rodeio, em Aceguá tem o local ali que faz o rodeio. Festa das crioulas, como diz o gaúcho, né? A GENTE VIVE mais o clima do gaúcho aqui né? NÓS SOMOS mais gaúcho, NÓS USAMOS bombacha, bota, eu é que não uso, mas eu tenho a minha roupa de gaúcho. Quando eu vou numa festa gaúcha eu uso gaúcho.

(MAN, homem, acima de 50 anos, brasileiro, ensino fundamental)

- Referência específica de primeira e terceira pessoa do singular (Eu + Ele (s))

Referência específica ao próprio falante e a uma terceira pessoa identificada pelo discurso. No primeiro exemplo, a pergunta e a resposta foram direcionadas à família do entrevistado. No segundo exemplo, não é só o entrevistado que tem o piquete, mas a família como um todo. 
Entrevistador: Legal. Muito legal. E aí a Mari estava me dizendo também da escola, que vocês preferem a brasileira né?

Claro, porque as possibilidade deles continuarem e de fazer uma faculdade, pra NÓS AQUI, pela situação geográfica que A GENTE tá, vai ser no Brasil.

(ALE, homem, acima de 50 anos, uruguaio, ensino médio)

Entrevistador: Vocês moram aqui do lado do Brasil?

Entrevistado: Do lado brasileiro A GENTE mora.

(EDU, homem, de 15 a 30 anos, brasileiro, ensino médio)

Entrevistada: Bastante, totalmente. Vamos dizer que é o entrevero dos dois, é a mistura dos dois. Porque, por exemplo, até mesmo, quando fala assim: NÓS TEMOS um piquete de carreta andarenga. O que é carreta? É carro de boi, carreta. Andarenga já é um termo que não existe nem no Brasil, nem no Uruguai.

(FLA, mulher, 31 a 49 anos, brasileira, ensino superior)

\section{- Referência específica de primeira pessoa do singular e segunda pessoa do plural (Eu + Vocês)}

$\mathrm{O}$ falante se refere a ele e aos entrevistadores como referência à primeira pessoa do plural. Como estava acompanhada nas duas viagens para a pesquisa de campo, em algumas entrevistas, esses dados ocorreram, uma vez que o colaborador interage com todos os presentes, ainda que apenas eu fosse a entrevistadora. Para esse fator, não há dados de nós e a gente com referência específica [Eu + Vocês] na fala dos uruguaios, mas apenas na fala dos brasileiros.

Meu filho, eu vou deixar vocês, porque eu vou em casa que tenho que fazer... mas A GENTE CONVERSA na viagem.

(MAN, homem, acima de 50 anos, brasileiro, ensino fundamental)

Entrevistadora: Aqui a estrada é livre?

Entrevistado: É, Bagé.

Entrevistadora: Ah é.

Entrevistado: Indo pra Bagé aqui, agora VAMO ENTRAR em caminho de chão.

(MAN, homem, acima de 50 anos, brasileiro, ensino fundamental)

- Referência específica de primeira e segunda pessoa do singular (Eu + Você)

Quando o falante se refere apenas a ele próprio e ao entrevistador como referência à primeira pessoa do plural. $\mathrm{O}$ assunto também era bem específico, tendo em vista que não faço parte dessa comunidade. Não há dados de nós e a gente com referência específica [Eu + Você] na fala dos uruguaios, mas apenas na fala dos brasileiros. 
Entrevistador: Ah tá, dez e meia é o intervalo deles?

Entrevistada: Dez e meia até onze horas, aí A GENTE GRAVA.

(CAR, mulher, de 31 a 49 anos, brasileira, ensino superior)

E eu não entendi o que ele falava ali. Ele fala totalmente diferente de NÓS. A senhora não fala assim...

(JOS, homem, 15 a 30 anos, brasileiro, ensino médio)

\section{- Discurso reportado específico}

Quando o entrevistado cita a fala de outra pessoa, mas com referência específica. Nesse caso, somente há dados de nós e nos.

Jaq: para de hablar los políticos que ellos son brasilero...

Car: Pero no me importa.

Entrevistadora: Não, mas é verdade.

Jaq: No ve que ellos vienen de Brasília.

Car: pero y por eso, pues, pueden llegar lá e dizer: lá tem um castelhano,

gaúcho, un canário grosso, de lá, e tudo o que NOS falou. Yo digo que o Brasil, no vota, vota fulano, Romário se candidatou, o Tiririca. Tu pode acreditar... Como un hombre que no sabe escribir, que no sabe escribir? Como puede ser, o cara mais votado dentro de... mais votado. ${ }^{88}$

$\left(\mathrm{CAR}^{89}\right.$, homem, acima de 50 anos, uruguaio, ensino médio)

Seu Manoel - Entrevistado: Não, e outra coisa, os cara vem de Bagé por exemplo, encosta o carro ali, nem o posto Ipiranga tem... meu filho que é gerente do posto Ipiranga ali, e ele "pai, o negócio ... NÓS PENSÁVAMOS que IA TRABALHAR bem, até IA ABRIR UMA LANCHERÍA e não VAMO ABRIR, porque eles chegam".

(MAN, homem, acima de 50 anos, brasileiro, ensino fundamental)

\section{- Discurso reportado genérico}

Quando o entrevistado cita a fala de outra pessoa, mas com referência genérica. Somente há esses dados de nós e a gente em discurso reportado genérico na fala dos brasileiros.

eu dizia, te mando até o comprovante de sedex que eu te mandei, eu não, o ministério da agricultura", ele "ah, ta, sendo assim A GENTE vai ver o que faz", "não, se tu quer se responsabilizar por 70 mil dólares do valor da carga morrendo aí no caminhão, eu mando até a imprensa ir tirar foto aí que a senhora deixou morrendo aí"

(EDI, homem, 31 a 49 anos, brasileiro, ensino superior)

\footnotetext{
${ }^{88}$ Único dado uruguaio com discurso reportado específco.

${ }^{89}$ Esse colaborador nasceu em Montevidéu e se criou em Aceguá.
} 
Então nós perdemos muito nisso ai, e falta de incentivo,falta de uma política que faça a gente tá obrigando, passem em várias reuniões acima disso aí, que tenha alguém, por exemplo, um vereador que seja daqui do município, o prefeito que nunca falou de ir lá em Brasília e dizer "NÓS TEMOS um porto seco", vender o porto seco de Aceguá, não tem ninguém.

(EDI, homem, 31 a 49 anos, brasileiro, ensino superior)

\section{- Referência específica de primeira pessoa do singular (Eu)}

O pronome a gente, utilizado com a referência específica relacionada a "eu", está associado a primeira pessoa do singular. A identificação foi feita com base nas marcas do contexto e do discurso. No primeiro exemplo, o falante usa a gente e logo em seguida corrige para "eu". No segundo exemplo, depois dos dois dados implícitos de nós, também há a presença do pronome "eu".

Aí A GENTE, eu preparei esse trabalho, tinha um monte de material, porque o estudo né. Olha...

(FLA, mulher, 31 a 49 anos, brasileira, ensino superior)

Entrevistadora: Ah, então, você pode olhar a pessoa e também, não perguntar e já marcar que é mulher.

Entrevistada: Mas NO PODEMO FAZER isso. Não PODEMOS DEDUZIR. Eu não posso deduzir que Cintia é mulher porque to vendo que é mulher. Eu tenho que te perguntar.

(RAD, mulher, acima de 50 anos, uruguaia, nível médio)

As pistas contextuais podem estar antes ou depois do dado em questão. No próximo exemplo, é possível identificar marcas de primeira pessoa do singular antes do pronome a gente em questão.

Entrevistada: A escolaridade interfere, a questão assim de aprender tanto no
Uruguai quanto no Brasil, cada um aprende a sua língua e aprende a língua
vizinha também, isso ajuda a definir também. Agora, EU ACHO que Aceguá,
assim, depois que virou Município, EU NOTEI assim, A GENTE NOTA
bastante diferença em relação a evolução da língua em relação assim, no
momento que as pessoas começam a participar mais, onde começa a existir
mais participação e mais influência assim dessa parte pública. Pode até ter
sido uma coincidência, porque eu também não tenho outras experiências.
Agora que aqui fez a diferença, fez. Assim tu via no cotidiano assim. Mudou,
mudou assim em relação, talvez essa questão assim de participação.

(FLA, mulher, 31 a 49 anos, brasileira, ensino superior)

Esses dados foram retirados da análise de peso relativo, tendo em vista que essa variação pertence à alternância de primeira pessoa do singular, e não do plural. Na variação de primeira pessoa do singular, as variantes seriam "eu", a gente usado como “eu” e também o nós usado como eu. Para a alternância de primeira pessoa do plural, 
foco de nosso trabalho, as variantes são nós e a gente com referência genérica e específica que inclua o "eu", mas também outra(s) pessoa, ou seja, que ainda tenha relação com o plural. Além disso, as análises estatísticas de nós e a gente com referência específica de primeira pessoa do singular "eu" não deram convergência.

O pronome a gente como "eu" também pode ser utilizado como uma estratégia de esquiva para não se expor, não se identificar ou não se comprometer em alguns contextos.

\section{- Opacidade}

Dados intercalados, incompletos ou truncados. Quando não tem marcas no contexto que nos permitam identificar o tipo de referência. Também optamos por excluir esses dados. Normalmente, são enunciados que terminam com o pronome, dificultando a identificação das pessoas e o pronome que sempre aparece é a gente, ou seja, não há dados de nós.

\footnotetext{
Eu conheci ele por intermédio de uma amiga em Melo. Eu tava em Montevidéu, vim para um aniversário, aí eu conheci ele. Aí A GENTE ...

(ROT, mulher, de 31 a 49 anos, uruguaia, ensino médio)

É, porque a cidade grande A GENTE...

(PIO, homem, acima de 50 anos, brasileiro, ensino fundamental)
}

$\mathrm{Na}$ análise de peso relativo, foram retirados os dados de a gente com a referência específica de "eu", por se tratar de fenômenos variáveis diferentes e que, talvez, pudessem enviesar os resultados, e os dados confusos ou opacos. O restante dos dados foi amalgamado como referência específica (eu+ele(s), eu + você(s), discurso reportado específico) e referência genérica (referência genérica e discurso reportado genérico).

\subsubsection{Tempo verbal/Saliência fônica}

A saliência fônica é proposta por Naro, Görski, Fernandes (1999) a partir das diferenças de material fônico na oposição singular/plural dos pronomes nós e a gente e suas respectivas concordâncias. 
A distribuição global na amostra do Rio de Janeiro (região Sudeste) mostra que a maioria das formas pretéritas está localizada principalmente nos níveis mais altos da saliência, enquanto o presente é encontrado principalmente em níveis mais baixos. A baixa saliência ocorre quando a saliência consiste somente na presença ou ausência do próprio - mos (muda/mudamos, sente/sentimos). Alta saliência é reconhecida quando há uma maior diferenciação fonética (mudou/mudamos, foi/fomos, vai/vamos) ou formas totalmente diferentes (é/somos) (NARO et alii, 1999, p. 203 e 205). A tabela de Naro et alii (1999, p. 203) demonstra que a hierarquia da saliência pode ser entendida como:

Quadro 5: Hierarquia da saliência segundo Naro et alii (1999, p. 203).

\begin{tabular}{|c|l|l|}
\hline Tipo de saliência & \multicolumn{1}{|c|}{ Exemplos } & \multicolumn{1}{c|}{ Explicação } \\
\hline 1 & falava/falávamos & $\begin{array}{l}\text { A oposição-V0-V-mos é } \\
\text { átona em ambas as formas. }\end{array}$ \\
\hline 2 & $\begin{array}{l}\text { fala/falamos, } \\
\text { trouxe/trouxemos }\end{array}$ & $\begin{array}{l}\text { A oposição -V0-V-mos é } \\
\text { tônica em uma das formas. }\end{array}$ \\
\hline 3 & $\begin{array}{l}\text { está/estamos } \\
\text { tem/temos }\end{array}$ & $\begin{array}{l}\text { A oposição -V0-V-mos é } \\
\text { tônica em ambas as formas. }\end{array}$ \\
\hline 4 & $\begin{array}{l}\text { comeu/comemos } \\
\text { partiu/partimos } \\
\text { vai/vamos } \\
\text { foi/fomos }\end{array}$ & $\begin{array}{l}\text { A oposição -V0-V-mos é } \\
\text { tônica em ambas as formas, e } \\
\text { a terceira pessoa do singular } \\
\text { mostra o ditongo com } \\
\text { semivogal que não aparece no } \\
\text { plural. }\end{array}$ \\
\hline 5 & $\begin{array}{l}\text { A oposição -V0-V-mos é } \\
\text { tônica em ambas as formas, e } \\
\text { a tônica muda a vogal. }\end{array}$ \\
\hline
\end{tabular}

Embora a oposição seja exclusivamente pela saliência fônica, pode-se fazer um paralelo com o tempo verbal. Assim, formas pretéritas somente ocorrem nos níveis 2, 4 e 5 e estão concentradas principalmente nos níveis 4 e 5 , ou seja, formas mais salientes. O presente está concentrado nos níveis 2 e 3, e o imperfeito apenas no nível 1, ou seja, na forma menos saliente.

Os resultados da variável tempo verbal são endossados também por Scherre e Naro (2014, p. 14-15) no que se refere ao princípio do evite proparoxítona no português brasileiro, uma vez que os tempos do presente e do pretérito são neutralizados na primeira pessoa do plural para verbos regulares nas três conjugações. Ao invés de nós pegávamos, prefere-se usar a concordância da terceira pessoa do singular como em $a$ gente pega ou nós pega, a gente pegava ou nós pegava.

Na perspectiva de Mattos (2013, p. 76), sobre nós e a gente em Goiás (região Centro-Oeste), a análise não foi de saliência fônica, mas de ritmo. Segundo a autora, 
sabe-se que o português brasileiro acentua as três últimas sílabas, ou seja, oxítona, paroxítona e proparoxítona, mas a maioria das palavras tem acento na penúltima sílaba (paroxítona). As poucas proparoxítonas são reintroduzidas na língua por meio de empréstimos do latim e do grego. Assim, o português brasileiro é uma língua tipicamente paroxítona, enquanto a proparoxítona é menos frequente e é contrária à tendência maior das palavras. Segundo Couto (2006, p. 88), a explicação fonéticofonológica é de que a paroxítona tem um padrão acentual não-marcado, devido ao fato de a última sílaba ser leve.

Dessa forma, a desinência -mos está para as proparoxítonas assim como seu abreviamento ou ausência está para as paroxítonas. A expansão de -mos para a gente não atinge ainda o português uruguaio e o português brasileiro da fronteira. Posto isso, é interessante notar que o pronome a gente também é uma estratégia de esquiva das comunidades urbanas para manterem a concordância com as paroxítonas (a gente falava) ao invés de manter uma concordância com as proparoxítonas (nós falávamos) ou utilizarem uma concordância não padrão (nós falava).

Posteriormente a essas análises, Naro, Scherre, Foeger e Benfica (2014) reanalisam a questão da saliência fônica e do tempo verbal na concordância de primeira pessoa do plural a partir de resultados de três comunidades: Santa Leopoldina no Espírito Santo, Baixada Cuiabana em Cuiabá e Vitória no Espírito Santo.

Para Naro et alii (2014, p. 1), é importante observar que no Brasil os paradigmas dos verbos regulares das três conjugações com formas plurais são foneticamente idênticos no presente e no pretérito com a desinência -mos (nós cantamos, nós bebemos, nós saímos). Em outras palavras, as duas formas são neutralizadas no nível fonético e há potencial ambiguidade entre presente e passado. Isso não ocorre na primeira conjugação, em Portugal, onde há uma diferença na realização fonética da vogal acentuada, com uma vogal fechada no presente e uma vogal aberta no pretérito. Mesmo assim, os verbos regulares das segunda e terceira conjugações têm foneticamente formas ambíguas, em ambos os países.

Portanto, nessa nova variável, estão imbricados a saliência e os aspectos do tempo verbal ambíguo ou entre presente (falamos) e pretérito perfeito (falamos). Assim, a ambiguidade da forma - mos é interpretada como sendo uma neutralização (Naro et alii, 2014, p. 6). A forma zero já não é ambígua e refere-se ao passado (A gente falou ou nós falou). A redivisão das categorias é: 
Quadro 6: Tempo verbal reinterpretado com base na neutralização segundo Naro et alii (2014, p. 10).

\begin{tabular}{|l|l|}
\hline Categorias em termos de registro padrão & $\begin{array}{l}\text { Formas de primeira pessoa do plural } \\
\text { com nós, sem ou com a desinência -mos }\end{array}$ \\
\hline $\begin{array}{l}\text { Pretérito com neutralização com o presente: a } \\
\text { mesma forma em ambos os tempos. }\end{array}$ & Nós mudou/nós mudamos. \\
\hline $\begin{array}{l}\text { Presente com neutralização com o pretérito: a } \\
\text { mesma forma em ambos os tempos. }\end{array}$ & Nós muda/nós mudamos. \\
\hline $\begin{array}{l}\text { Pretérito sem neutralização com o presente: } \\
\text { formas distintas para cada tempo. }\end{array}$ & Foi/fomos \\
\hline $\begin{array}{l}\text { Presente sem neutralização com o pretérito: } \\
\text { formas distintas para cada tempo. }\end{array}$ & Vai/vamos \\
\hline Imperfeito & Morava/morávamos. \\
\hline
\end{tabular}

A interpretação de Naro et alii $(2014$, p. 10) é de que -mos é favorecido pelo pretérito com ou sem neutralização, pois não há possibilidade de ambiguidade com o presente. O imperfeito desfavorece -mos. Para a alternância pronominal, o imperfeito, juntamente com o presente, tende a favorecer o uso de a gente enquanto o pretérito favorece nós.

Para Naro et alii (2014, p. 11), na dimensão linguística desse fenômeno morfossintático, atuam tendências gerais do tempo verbal e da saliência fônica com motivação (i) funcional (para desfazer a possibilidade de neutralização entre pretérito perfeito e presente), (ii) cognitiva (reservar o morfema -mos para formas mais salientes) e (iii) estrutural (evitar proparoxítonas) no português brasileiro.

Assim, em nossa variável, o tempo verbal/saliência fônica também foi codificado nos dados de sujeito, porque é justamente essa função sintática que desempenha a concordância com o verbo. Seguimos a proposta mais atual de Naro et alii (2014), por entendermos ser mais complexa e abrangente para captar as nuances de tempo e saliência.

De uma forma mais geral, fizemos uma codificação que levasse em consideração os aspectos da saliência, do ritmo e da neutralização. A hipótese era que os tempos presente do indicativo (a gente aprende, a gente fala) e pretérito imperfeito (a gente tinha/a gente usava, a gente recebia) favoreceriam a gente, especialmente porque o uso da forma nós cantemo (presente) ou cantemo (pretérito perfeito) é muito comum na fronteira e não ocorre com o pronome a gente.

Por essa razão, o tempo verbal, de certa forma, já marca uma diferença entre os pronomes, o que poderia evitar a ambiguidade das formas idênticas cantamos tanto para o presente como para o pretérito perfeito. A hipótese também é que, se ressaltasse a especialização temporal, estaria na distinção morfológica entre cantamo (presente) e 
cantemo (pretérito perfeito). Em outras variedades do português brasileiro rural, a forma cantemo é sempre pretérito perfeito, diferentemente do português brasileiro e uruguaio da fronteira, já que essa neutralização pode significar tanto presente como passado, ou seja, mantendo a ambiguidade.

Em geral, no espanhol, a possibilidade de proparoxítona (nosotros decíamos ou nostros decíamo) é mais recorrente, porque nosotros, com a desinência de plural, é o único pronome que exerce a função de primeira pessoa do plural. Cabe, agora, conferir se em uma situação bilíngue os contextos linguísticos condicionadores de a gente são os mesmos do português brasileiro.

No caso do português falado, a tendência é evitar as proparoxítonas (nós falávamos), já que o português é uma língua predominantemente paroxítona (a gente fala). A paraxitonização refere-se também à saliência fônica, porque a gente fala ou nós fala é menos saliente, e, portanto, mais frequente e preferido no português que nós falávamos, que é mais saliente.

A oposição "fala-falamos" ou "falava/falávamo" na perspectiva de Naro, Görsky e Fernandes (1999) é menos saliente. Na perspectiva do "evite propararoxítona", "nós falávamos" é saliente na língua. Na perspectiva social, da comunidade urbana, "nós fala" e "nós falava" é também saliente. O imperfeito favorece a gente para evitar a proparoxítona, e o perfeito favorece -mos, que, no nosso caso, só poderia ter o pronome nós como sujeito desse verbo, uma vez que essa desinência ainda não se expandiu para a fronteira.

Assim, exemplificamos como ficou a variável tempo verbal/saliência fônica para a análise de peso relativo. Os verbos irregulares têm mais saliência fônica e são todos sem neutralização. Com neutralização, a maioria é regular e tem baixa saliência fônica.

\section{- Pretérito perfeito com neutralização em verbos regulares}

Verbos regulares do pretérito perfeito que alternam entre oxítona, para o pronome a gente, e paroxítona para o pronome nós, e têm a saliência 5 ou 4 . Ex: gastou/gastamos e ligou/ligamos (saliência 5), bateu/batemos e dormiu/dormimos (saliência 4). 
- Pretérito perfeito com neutralização em verbos irregulares

Verbos irregulares do pretérito perfeito que alternam predominantene de oxítona, para o pronome a gente, e paroxítona para o pronome nós, e têm a saliência 4 (subi/subimos, saí/saímos, consegui/conseguimos, fugi/fugimo).

\section{- Pretérito perfeito sem neutralização em verbos irregulares}

Verbos irregulares do pretérito perfeito que alternam de paroxítona para paroxítona em ambos os pronomes com verbos de saliência 3 (teveltivemos, saiu/saímos, veio/viemo). E alternam de oxítona para paroxítona com verbos de saliência 4 (foi/fomos, viu/vimos) e 5 (fez/fizemos).

- Presente sem perífrase com neutralização em verbos regulares

Verbos regulares do presente com saliência 2 e que alternam entre paroxítona, para a gente, e paroxítona, para nós (fala/falamos, conhece/conhecemos; assiste/assistimos).

- Presente com perífrase e com neutralização em verbos regulares

Verbos regulares do presente com perífrase, com saliência 2 e que alternam entre paroxítona, para a gente, e paroxítona, para nós (precisa/precisamos).

- Presente com neutralização em verbos irregulares

Verbos irregulares do presente com saliência 4 e que alternam entre paroxítona, para a gente, e paroxítona, para nós (sai/saímos, distraí/distraímos).

- Presente sem neutralização em verbos irregulares

Verbos irregulares do presente com saliência 3, 4 e 5 , e que alternam predominantemente entre oxítona e paroxítona. Ex: estálestamos, táltamos, põe/pomos, 
vê/vemos, dáldamos (saliência 3); é/somos (saliência 5) e ir - perífrase ou ir movimento (saliência 4). Há dados também de saliência 2, mas de verbos que alternam entre paroxítona e paroxítona (pode/podemos; sabe/sabemos).

\section{- Imperfeito do indicativo em verbos regulares}

Verbos regulares de saliência 1 do imperfeito do indicativo, que alternam entre paroxítona e proparoxítona (falava/falávamos, junta/juntávamos, paga/pagávamos, levantava/levantávamos).

\section{- Imperfeito do indicativo em verbos irregulares}

Verbos irregulares do imperfeito do indicativo com saliência 1 e que alternam entre paroxítona e proparoxítona (era/éramos, tinha/tínhamos, estavalestávamos, tavaltávamos, sabia/sabíamos, fazialfazíamos, ia/íamos, saíalsaíamos, vinha/vínhamos).

\section{- Futuro do pretérito}

Verbos no futuro do pretérito, com saliência 1 e que alternam entre paroxítona e proparoxítona (poderia/poderíamos, gostaria/gostaríamos, precisaria/ precisaríamos).

\section{- Imperfeito do subjuntivo}

Verbos no imperfeito do subjuntivo, com saliência 1 e que alternam entre paroxítona e proparoxítona (fosse/fôssemos).

\section{- Futuro morfêmico}

Verbos no presente do subjuntivo (façalfaçamos) com saliência 1 e que alternam entre paroxítona e paroxítona; verbos no futuro do subjuntivo (meter/metermos, tiver/tivermos) com saliência 3 e que alternam entre oxítona e paroxítona; e verbos no 
infinitivo (ficarlficarmos, fazer/fazermos, ir/irmos) com saliência 2 e que alternam entre oxítona e paroxítona.

\section{- Gerúndio}

Verbos no gerúndio alternando entre a gente e nós (a gente podendo te ajudar/ nós sendo uruguaio).

Interessante notar que não há dados de futuro do subjuntivo no português uruguaio, e no presente do subjuntivo não há dados de a gente. No português brasileiro, a gente aparece em todos os casos, exceto no tempo presente do subjuntivo. A categoricidade ou semi-categoricidade de alguns tempos verbais e de algumas funções sintáticas nos possibilitam inferir, novamente, que a inserção da variante a gente no português uruguaio ainda é recente e, por isso, menos frequente em alguns contextos, diferentemente do português brasileiro, que se encontra em fase mais avançada na mudança em progresso e na gramaticalização do pronome.

\subsection{Análise conjunta dos resultados de brasileiros e uruguaios}

Nesta seção, optou-se por fazer uma análise geral com todos os colaboradores, porque a intenção é compreender, primeiramente, a comunidade de Aceguá a partir de todo o corpus formado por uruguaios e brasileiros.

Além do entendimento global da comunidade, os fatores sociais de agrupamento dos dois povos e da união dos membros nos permitem fazer essa análise, porque ambos se consideram pertencentes a uma única comunidade e não costumam se distinguir na convivência diária, ainda que estejam politicamente em dois países diferentes.

Assim, essa fronteira é dividida apenas politicamente, porque seus habitantes se identificam uns com os outros e vivem pacificamente, independentemente da nacionalidade, de qual lado moram ou de onde trabalham. A questão geográfica também favorece a união dos moradores, pois, como já sabemos, não há nenhum acidente geográfico dividindo os dois lados. Com relação à língua, o português falado também é compartilhado por uruguaios e brasileiros na fronteira. 
Para todas as análises de peso relativo e também para a análise geral (brasileiros e uruguaios), foi considerada apenas a função de sujeito, porque não houve convergência na análise dos pronomes em todas as funções sintáticas, nem mesmo quando juntamos sujeito versus outras funções. Para efeitos de comparabilidade das três análises, buscaram-se parâmetros semelhantes, ou seja, mesmas variáveis, fatores e amalgamações em todas as análises.

A partir da codificação individual de cada colaborador, foi possível identificar que, dos 38 colaboradores, 8 uruguaios e 3 brasileiros apresentavam comportamento categórico para o uso exclusivo de nós. Por conta disso e dos poucos dados de alguns colaboradores, fizemos outra análise retirando os falantes de efeito categórico.

Assim, apresentamos em todas as tabelas os dados com todos os colaboradores e sem os casos categóricos, mesmo porque, em algumas tabelas, há diferenças importantes para cada grupo. No momento em que se rodam todos os fatores sociais, retira-se a identificação do colaborador para que não haja sobreposição de variáveis.

Tabela 2: Percentagem global das variantes a gente e nós apenas na posição de sujeito do português brasileiro e do português uruguaio da amostra de Aceguá

\begin{tabular}{l|c|l}
\hline & \multicolumn{2}{|c}{ Colaboradores } \\
\hline Variantes & Com todos & Sem os categóricos de nós \\
\hline A GENTE & $452 / 1002=45,1 \%$ & $452 / 775=58,3 \%$ \\
\hline NÓS & $550 / 1002=54,9 \%$ & $323 / 775=41,7 \%$ \\
\hline
\end{tabular}

A percentagem de a gente $(58,3 \%)$ sem os casos categóricos reflete o outro lado do uso desse pronome pela comunidade da fronteira de Aceguá, uma vez que os colaboradores categóricos no uso de nós foram retirados.

Foram selecionadas pelo Goldvarb-X as variáveis sociais faixa etária e nacionalidade (apenas na análise com todos os colaboradores) e as variáveis linguísticas preenchimento do sujeito, tipo de referência (apenas na análise sem os casos categóricos), paralelismo linguístico e tempo/saliência fônica. O sexo dos colaboradores é a única variável que não é selecionada em nenhuma das três análises.

Algumas variáveis foram excluídas da análise estatística. O nível de escolaridade foi apenas controlado na amostra, porque a distribuição dos dados é bem irregular. Os entrevistados se encontram em grande maioria no nível médio, há poucos analfabetos e a maioria dos que fazem faculdade fora de Aceguá não voltam porque buscam mais oportunidades de trabalho. A função sintática foi retirada para a permanência apenas dos dados de sujeito por questões de comparabilidade das análises, uma vez que não 
havia convergência. E a variável da concordância de número também foi retirada, porque somente há variação de número quando não há sujeito explícito e a concordância está no singular.

Assim sendo, exemplificamos e analisamos as variáveis sociais e linguísticas que condicionam esse fenômeno na comunidade de Aceguá de ambos os lados da fronteira. Os resultados serão apresentados em função do pronome a gente, variante inovadora, que desencadeia o processo da mudança linguística no português uruguaio da fronteira, a partir de seu aparecimento nessa variedade como pronome de primeira pessoa do plural, e se expande no português brasileiro da fronteira.

\subsubsection{Variáveis sociais}

Para a codificação dos dados, foram analisadas as variáveis sociais tipicamente labovianas, como sexo e faixa etária. A nacionalidade também foi controlada, uma vez que temos 19 colaboradores uruguaios e 19 colaboradores brasileiros. Os entrevistados foram codificados individualmente, mas a análise não incluiu essa variável macro por ser equivalente às microcategorias sociais, o que certamente ocasionaria uma sobreposição de fatores, como se pode observar na Tabela 3.

Tabela 3: Efeito das variáveis sociais em relação ao pronome $a$ gente no português brasileiro e no português uruguaio da amostra de Aceguá

\begin{tabular}{|c|c|c|c|c|c|c|}
\hline & \multicolumn{6}{|c|}{ Colaboradores } \\
\hline & \multicolumn{3}{|c|}{ Com todos } & \multicolumn{3}{|c|}{ Sem os categóricos de nós } \\
\hline Variáveis sociais & $\begin{array}{c}\mathbf{N} \text { de dados/ } \\
\text { Total }\end{array}$ & $\begin{array}{c}\text { Percen- } \\
\text { tagem }\end{array}$ & Peso & $\begin{array}{c}\text { N de dados/ } \\
\text { Total }\end{array}$ & $\begin{array}{c}\text { Percen- } \\
\text { tagem }\end{array}$ & Peso \\
\hline \multicolumn{7}{|l|}{ Faixa etária } \\
\hline 15 a 30 anos & $154 / 296$ & $52,0 \%$ & 0,58 & $154 / 187$ & $82,4 \%$ & 0,74 \\
\hline 31 a 49 anos & $201 / 406$ & $49,5 \%$ & 0,50 & $201 / 351$ & $57,3 \%$ & 0,45 \\
\hline Acima de 50 anos & $97 / 300$ & $32,3 \%$ & 0,41 & $97 / 237$ & $40,9 \%$ & 0,35 \\
\hline \multicolumn{7}{|l|}{ Nacionalidade } \\
\hline Brasileira & $317 / 541$ & $58,6 \%$ & 0,62 & $317 / 500$ & $63,4 \%$ & {$[0,52]$} \\
\hline Uruguaia & $135 / 461$ & $29,3 \%$ & 0,35 & $135 / 275$ & $49,1 \%$ & {$[0,45]$} \\
\hline \multicolumn{7}{|l|}{ Sexo } \\
\hline Mulher & $278 / 556$ & $50 \%$ & {$[0,53]$} & $278 / 441$ & $63 \%$ & {$[0,49]$} \\
\hline Homem & $174 / 446$ & $39 \%$ & {$[0,45]$} & $174 / 334$ & $52,1 \%$ & {$[0,51]$} \\
\hline Total & $452 / 1002$ & $45,1 \%$ & & $452 / 775$ & $58,3 \%$ & \\
\hline Input & & & 0,42 & & & 0,62 \\
\hline
\end{tabular}


Os pesos relativos entre colchetes significam que essas variáveis não foram selecionadas estatisticamente, mas que esses valores estão no último nível, antes da seleção, que testa a significância do sexo e da nacionalidade. A significância do sexo na análise com todos os colaboradores é de 0,070 , ou seja, com grande probabilidade de ser selecionado, mas na análise sem os casos categóricos a significância passa a ser de 0,757, com uma possibilidade bem remota de ser selecionado. Nota-se também que todos os pesos são próximos a 0,50 e não inferiores a 0,45.

No sentido da mudança linguística, a hipótese para a faixa etária é de que os jovens seriam mais inovadores favorecendo o pronome a gente do que a geração de mais idade, que tenderia a ser mais conservadora quanto ao uso de variantes novas, o que significaria desfavorecimento de a gente. Além disso, o objetivo central seria comprovar a mudança linguística em tempo aparente, ou seja, a distribuição de formas linguísticas ao longo de uma estratificação etária que pressupostamente reflete gerações sucessivas. Para Labov (2008, p. 194),

\footnotetext{
os dados mais simples para se estabelecer a existência de uma mudança linguística são um conjunto de observações de duas gerações sucessivas de falantes - gerações de características sociais comparáveis que representam estágios na evolução da mesma comunidade de fala.
}

Nosso estudo é de tempo aparente, por meio das diferentes faixas etárias, e, a partir disso, também é possível refletir o tempo real sobre a entrada de a gente no português uruguaio da nossa amostra em relação à ausência desse mesmo pronome relatado em outros trabalhos, especialmente o registro de inexistência de a gente como primeira pessoa do plural feito por Elizaincín, Behares e Barrios (1987, p. 85), na década de 70 .

No momento sincrônico da pesquisa, de acordo com a Tabela 3, os colaboradores que favorecem o uso de a gente são, de fato, os jovens com 0,58 para todos os colaboradores e 0,74 sem os casos categóricos. Em contrapartida, do lado mais conservador da faixa etária, encontram-se as pessoas com mais de 50 anos que desfavorecem o uso de $a$ gente, com 0,41 e 0,35, respectivamente, na análise com todos e sem os casos categóricos.

A faixa intermediária dos adultos está no ponto neutro no uso de a gente $(0,50)$ na análise com todos os dados. Para Guy e Zilles (2007, p. 239), o ponto neutro de 0,50 para análise binária (duas variantes, como é nosso caso) é quando o valor de um fator nem favorece, nem desfavorece o uso da variante investigada ao obter uma frequência 
de ocorrência próxima da frequência total do corpus. Na faixa etária intermediária da análise com todos os colaboradores, a frequência é de 49,5\%, próxima da frequência total dos dados, que é de $45,1 \%$. Na análise sem os casos categóricos, os adultos também desfavorecem o uso de a gente $(0,45)$ juntamente com os que em mais de 50 anos.

Com esses resultados, podemos entender que os valores sobre a primeira pessoa do plural são inversamente proporcionais à faixa etária, pois, quanto menos idade, maior o uso de a gente e quanto mais idade, menor o uso de a gente. Ou seja, adultos (faixa intermediária) e os de mais idade desfavorecem o uso de a gente, enquanto jovens lideram a mudança linguística de 0,58 (com todos os dados) a 0,74 (sem os casos categóricos).

Percebe-se que a identidade dos jovens se assemelha aos padrões linguísticos mais prestigiados da sociedade, que se distancia dos falantes de mais idade, já que estes ainda se identificam mais com a cultura e a linguagem local. Como a gente tem mais prestígio, também por ser um pronome típico do português brasileiro monolíngue urbano, os jovens tendem a incorporar esse padrão linguístico. Dessa forma, os grupos sociais da faixa etária são comunidades de fala ligeiramente diferentes (LABOV, 2008, p.188). Em suma, sobre essa distinção etária, Labov (2008, p. 133) afirma que

há motivos para crer que falantes mais velhos têm menos capacidade de mudar, e que só os muito jovens, recém-saídos da pré-adolescência, conseguem fazer mudanças radicais no seu padrão graças à atenção consciente.

Outro fato importante é que os falantes de mais idade dão pouca atenção às perguntas do entrevistador e falam muito sobre suas experiências pessoais e profissionais. Labov (2008, p. 116) chama esse contexto de "Fala que não responde diretamente a pergunta". Assim sendo, quanto mais à vontade o (a) colaborador (a) fica e quanto mais ele/ela fala, maior a chance de apresentar o vernáculo verdadeiro, e, no nosso caso, o vernáculo que reflete bem o falar da fronteira na época em que a linguagem foi adquirida pelos falantes adultos e de mais idade.

A escolha de a gente ou nós também é consequência da nacionalidade e/ou grau de bilinguismo do colaborador. Como se trata de uma comunidade fronteiriça, pressupõe-se que o pronome a gente ocorra mais na fala de brasileiros, uma vez que o pronome que ocupa esse espaço no espanhol uruguaio é o nosotros, correspondente ao pronome nós do português. Posto isso, a hipótese da nacionalidade foi corroborada e 
comprovada com o peso relativo de 0.62 de a gente na fala de brasileiros, contra apenas 0.35 na fala de uruguaios quando rodamos todos os colaboradores.

Interessante notar é que, quando retiramos os casos categóricos, a nacionalidade não é selecionada estatisticamente. E no nível onde essa variável poderia ser selecionada, o nível de significância é de 0,172 , ou seja, pouca probabilidade de seleção. Quando estão todos juntos, há o efeito da nacionalidade porque há diversos falantes que ainda não entraram na "onda" da mudança linguística com a inserção de $a$ gente no seu vernáculo, sobretudo dos uruguaios. Quando se retiram esses dados, o grupo que permanece reflete exatamente o que está em processo de mudança. Portanto, a nacionalidade perde a força e as diferenças sociais entre os dois lados da fronteira se neutralizam, o que nos permite afirmar que reflete, nesse momento, uma comunidade coesa socialmente.

Fazendo uma relação entre nacionalidade e faixa etária, é possível inferir que a variante a gente pode ser uma mudança linguística mais recente no português uruguaio, uma vez que essa inovação do português brasileiro está cruzando a fronteira e adentrando em um dialeto que, por definição, era mais conservador e rural, da mesma forma que ocorre com os fenômenos da palatalização /del e /dil (CARVALHO, 2008) ou (lh) (CARVALHO, 2003).

Do ponto de vista do prestígio, a variação de primeira pessoa do plural não é vista como "erro" pela sociedade, não é objeto de estigma ou preconceito social, e é um pronome tipicamente urbano e prestigiado por pessoas que almejam aproximar-se do português brasileiro.

Deve-se levar em conta também a influência dos padrões externos à comunidade que afetam a preferência linguística dos jovens, fatores que os fazem utilizar mais a variante nova como rumo à variedade monolíngue prestigiada do português brasileiro. Provavelmente os uruguaios buscam incorporar as formas linguísticas distintivas do português brasileiro no intuito de se aproximarem dessa variedade linguística.

Esses padrões extrínsecos aos uruguaios da fronteira refletem a mudança linguística com consciência social (change from above). Nas palavras de Labov (1972, p. $123 ; 2001$, p. 272-284), esse tipo de mudança significa que a mudança vem de fora, ou seja, no nosso caso, do português brasileiro.

No Brasil, esse movimento é claramente sem consciência social (change from below), já que é intrínseco à própria língua, ou seja, mais natural. Se pensarmos que é um fenômeno provavelmente não estigmatizado (ZILLES, 2007, p. 37), tanto no 
português uruguaio como no português brasileiro da fronteira, também é possível interpretar esse fenômeno como uma mudança sem consciência social (change from below) também em Aceguá. Mais uma vez, as explicações para a fronteira têm de ser relativizadas, já que de fato há um continuum que vai e volta desde o português uruguaio até o português brasileiro da fronteira (CARVALHO, 2003b).

Os maiores favorecedores de a gente na análise conjunta de uruguaios e brasileiros são os jovens $(0,74)$, ou seja, são eles que lideram a mudança linguística, sendo, portanto, os responsáveis pelo alto uso de a gente como pronome de primeira pessoa do plural. Certamente esse uso tem como consequência outros fatores sociais por que passa a fronteira. Como exemplo desses fatores extralinguísticos, temos a alta valorização econômica, social e política do Brasil, da valorização do real, da elevada taxa de emprego no Brasil, a questão midiática, sobretudo da Rede Globo. Com relação à televisão e à influência da mídia, Carvalho (2008) já relatava a interferência da Rede Globo no jeito de falar da fronteira. Nesse sentido, segue abaixo um depoimento de um uruguaio de Aceguá, confirmando o mesmo padrão midiático.

Entrevistador: E aí vocês também têm acesso a Globo assim?

Entrevistado: Sim, sim.

Entrevistador: Desde quando vocês têm acesso a Globo? Tem muito tempo?

Entrevistado: Ah sim, a Globo sim. Antes tinha um só canal, aqui pegava um só canal, mas que era a Globo, que não tinha parabólica, ficava na Texaco, no posto Texaco ali uma antena. Mas aí veio uma tempestade, caiu um raio e queimou tudo.

Entrevistador: É, eu vim nessa época aí, uns dois anos.

Entrevistado: Tá. Queimou tudo. E aí botaram a antena lá e pegava a TVS. E agora tem um cable uruguaio, esse tá acho que com dezoito, vinte canal.

Entrevistador: E o pessoal aqui no Uruguai assiste mais a Globo?

Entrevistado: Ah sim, Globo. Te para a olhar e termina na Globo, em novela, e futebol, enfim.

Entrevistador: A Globo atraiu todo mundo né?

Entrevistado: Pá mim, me paro a mexer nesses canal, termino sempre na Globo.

Entrevistador: E Noblia, esses lugares mais pra dentro, também tem Globo?

Entrevistado: Tem Globo, tem o cable, esse tal de cable.

Entrevistador: E eles também assistem bastante?

Entrevistado: Sim, sim, Globo, novela.

Entrevistador: Chega a Melo?

Entrevistado: Chega.

Entrevistador: Chega né? A Globo está em tudo.

Entrevistado: Acho que a Globo chega em todo, tendo cable parabólica chega em todo o país.

Entrevistador: E essa parabólica vocês tem que pagar, como é que é?

Entrevistado: O cable paga, dá trinta, trinta e cinco reales, porque é por mês. É que nem Sky, só que...

Entrevistador: Só pega Globo quem tem parabólica?

Entrevistado: Não, quem não tem pega TVS. 
Entrevistador: Ah tá.

Entrevistado: Mas da TVS tem a Globo também, sinal com a Globo.

(JEF, homem, de 15 a 30 anos, uruguaio, ensino médio)

Em Aceguá, a vida dos moradores é voltada para o polo do Brasil, no sentido de emprego, saúde, moradia, assistência etc. Nesse sentido, as questões linguísticas tendem a acompanhar o processo histórico e social vivenciado pela comunidade. É perceptível, portanto, a predominância do uso do português na fronteira. No caso do fenômeno linguístico em questão, registramos a "entrada" do pronome a gente no português uruguaio também como uma forma de se aproximar da realidade e da linguagem brasileira. O mesmo colaborador acima afirma que o português é falado ou entendido por todos da fronteira.

Entrevistador: Legal. $\mathrm{E}$ a fronteira, tanto a parte do Uruguai quanto a parte do Brasil fala mais português mesmo?

Entrevistado: Sim, sim. Todos falam português. E o que não fala, entende. Porque as pessoa mais véia assim, tem uma pessoa véia que não te fala o português, mas são mui veia, mas algo entende. Com o tempo vai entendendo, porque tem o filho né.

Entrevistador: Tu acha que é mais fácil o uruguaio falar português ou o brasileiro falar espanhol? Assim, que eu percebo, eu escuto mais português do lado uruguaio. Mas, os brasileiros falando espanhol na maioria das vezes, não...

Entrevistado: Sim, é mais difícil porque eles não têm o mesmo que NÓS TEMO.

Entrevistador: Vocês parecem ter mais facilidade né?

Entrevistado: Claro, não, o problema NOSSO é que NÓS TEMO uma, NÓS CONVIVEMO mais com o lado brasileiro, ou seja, NÓS VEMO TV, NÓS ESCUTEMO rádio. Eles o único que escutam NOSSO é o rádio, que tem duas emissora aqui.

Entrevistador: É verdade.

Entrevistado: Mas NÓS não, NÓS TEMO a televisão que desde pequeno, cresce, nasce OIANDO TV, é diferente.

Entrevistador: É verdade. E vocês tem mais contato lá. Se bem que eles trabalham aqui também né?

Entrevistado: Sim, sim, trabalham entre meio... é bem, mas no caso do comércio, o mais forte é o lado brasileiro.

Entrevistador: Ah, aí vocês estão sempre mais voltados pra lá né?

Entrevistado: Claro, comércio forte mesmo é no Brasil, porque nesta região tem comércio, mas comércio tipo boteco, assim, coisa pequena.

(JEF, homem, de 15 a 30 anos, uruguaio, ensino médio)

A partir dessa citação, é possível perceber a influência do português na região de Aceguá por diversos fatores, tais como entendimento mútuo do português, hábito linguístico das práticas cotidianas e familiares, convivência maior do lado brasileiro, influência das mídias como televisão e rádio, comércio voltado para o Brasil etc. 
Em termos linguísticos, esse jovem uruguaio fala português, mas não utiliza $a$ gente como primeira pessoa do plural em nenhum momento da entrevista. Por isso, é sempre importante frisar que o a gente é cognato de la gente, que tem outra função totalmente diferente no espanhol. Em situações de contato, se espera que as semelhanças sejam reforçadas e as diferenças evitadas. Portanto, como la gente é tão diferente do uso pronominal do português, a hipótese inicial seria que o pronome $a$ gente fosse evitado e o nós reforçado no português uruguaio.

Em suma, no caso do português uruguaio, o fato de haver categoricidade na fala de alguns uruguaios também evidencia uma mudança recente, porque o efeito dos jovens ainda é maior na análise sem os casos categóricos $(0,74)$ comparada à análise com todos os colaboradores $(0,58)$. A nacionalidade é selecionada apenas na análise com todos os colaboradores $(0,62)$, justamente porque na análise sem os casos categóricos os falantes variam de forma similar entre os dois pronomes e ambas as comunidades deixam de distinguir quanto a esse uso linguístico.

Para continuar entendendo como a variação nós e a gente funciona no português uruguaio e no português brasileiro em conjunto, é preciso analisar, além dos fatores sociais, as variáveis linguísticas que condicionariam essa variação.

\subsubsection{Variáveis linguísticas}

Explicaremos a análise das variáveis linguísticas selecionadas pelo programa Goldvarb-X (preenchimento do sujeito, tipo de referência (apenas na análise sem os casos categóricos), paralelismo linguístico e tempo verbal/saliência fônica), de modo a permitir uma maior integração entre todas as variáveis e a interação entre todos os fatores linguísticos e sociais do trabalho. Ilustraremos os exemplos com tabelas e/ou gráficos com resultados em percentagem e peso relativo. A Tabela 4 reúne todas as variáveis linguísticas codificadas neste trabalho e estatisticamente significativas. 
Tabela 4: Efeito das variáveis linguísticas em relação ao pronome a gente no português brasileiro e no português uruguaio da amostra de Aceguá.

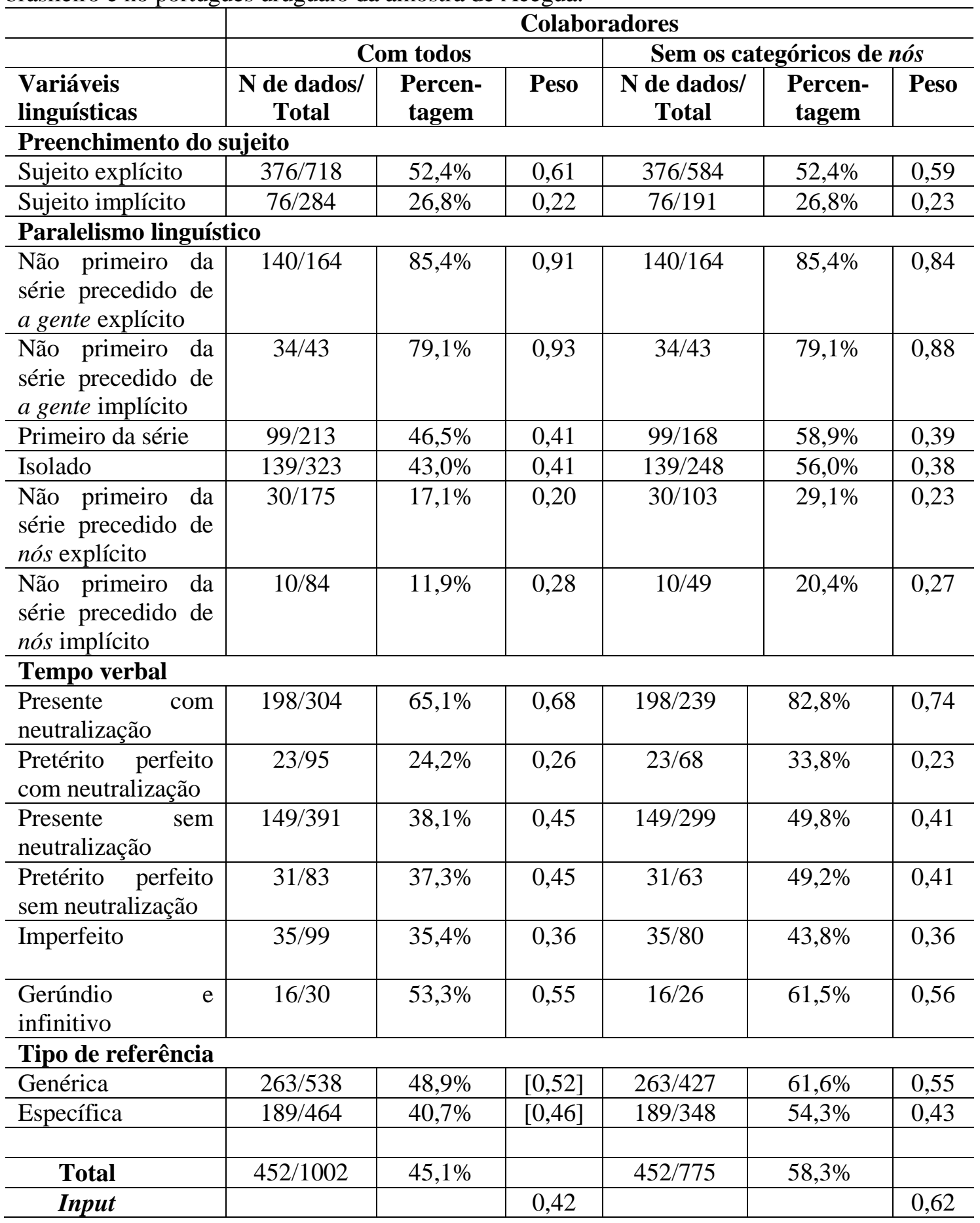

A partir dessa análise estatística, é possível ter uma ideia global de como os dados estão distribuídos entre as variáveis linguísticas e quais delas foram selecionadas estatisticamente. 
$\mathrm{Na}$ Tabela 4, com relação ao preenchimento do sujeito ${ }^{\mathbf{9 0}}$, o sujeito explícito favorece a presença do pronome a gente com 0,61 na análise com todos os colaboradores, e 0,59 na análise sem os casos categóricos. O fato de estar implícito dificulta saber quem é a pessoa do verbo, sobretudo quando se trata da concordância com a terceira pessoa do singular, correspondente ao pronome a gente. Como o paradigma verbal do português se alterou bastante, com o sujeito implícito fíca difícil saber se é tu foi, você (cê ou ocê) foi, ele foi, a gente foi, nós foi, ele foi, eles foi. Portanto, o sujeito implícito geralmente aparece com a desinência $-m o(s)$, o que favorece a associação ao pronome nós, mesmo porque, no português brasileiro e uruguaio de Aceguá, não há dados do tipo a gente vamos.

Os trabalhos variacionistas do português brasileiro (OMENA, 1986, 2003; LOPES, 1993, 1998; NARO et alii, 1999; MENDONÇA, 2010; dentre outros) e do português europeu (VIANNA, 2011) identificam o mesmo padrão de preenchimento do sujeito como fator condicionante da presença do pronome a gente. Assim, a explicitude do sujeito favorece o pronome a gente à medida que a implicitude favorece o pronome nós tanto no português brasileiro como no português uruguaio.

Sobre o paralelismo linguístico, é perceptível que, quando o pronome a gente é explícito ou implícito, o próximo dado tende a ser a gente na análise com todos os colaboradores $(0,91$ e 0,93 , respectivamente) e na análise sem os casos categóricos $(0,84$ e 0,88 ). Por outro lado, o pronome a gente é desfavorecido quando precedido de nós explícito $(0,20$ com todos os dados e 0,23 sem os casos categóricos de nós) e de nós implícito $(0,28$ com todos os dados e 0,27 sem os casos categóricos de nós).

No paralelismo linguístico (SCHERRE, 1998 e POPLACK, 1980), marcas levam a marcas e zeros levam a zeros no sentido de que a presença do pronome nós em um dado favorece o mesmo pronome posteriormente, da mesma forma que a presença de $a$ gente em um dado favorece o mesmo pronome posteriormente, ou seja, marcas explícitas e de mesma natureza favorecem as mesmas marcas no sentido de ocorrerem paralelamente. Assim, o paralelismo geralmente é selecionado como estatisticamente significativo em qualquer fenômeno linguístico variável.

Quando o pronome está isolado na sentença $(0,41$ ou 0,38$)$ ou é o primeiro da série $(0,41$ e 0,39), o peso relativo mostra que esses fatores têm um efeito

\footnotetext{
${ }^{90}$ Foram feitas novas análises estatísticas sem os dados de sujeito implícito, considerando apenas os dados de sujeito explícito. Não houve grandes diferenças nos resultados sociais e linguísticos de nenhuma análise, seja da comunidade como um todo, seja de brasileiros ou de uruguaios separadamente.
} 
desfavorecedor do uso de a gente, favorecendo a ocorrência do pronome nós nesses contextos. Normalmente, esses valores são mais intermediários quanto ao uso de $a$ gente, porque estão perto da neutralidade, o que confirma o fato de que é, de certa forma, indiferente a opção de nós ou a gente quando o pronome é o primeiro da série na maioria dos trabalhos.

Com relação à variável tempo/saliência fônica, o presente com neutralilzação $(0,68)$ e as formas nominais de gerúndio e infinitivo $(0,55)$ favorecem a presença do pronome a gente em detrimento dos demais tempos, na análise com todos os colaboradores. E a análise sem os dados categóricos traz poucas modificações, com 0,74 para o presente com neutralização e 0,56 para o gerúndio e infinitivo. O que está em jogo não é apenas tempo verbal, mas a neutralização do tempo presente, uma vez que o presente com neutralização favorece a gente (de 0,68 a 0,74) e o presente sem neutralização favorece nós (de 0,55 a 0.59).

O restante dos fatores não altera muito o resultado em peso relativo na análise com todos os dados ou na análise sem os casos categóricos, ou seja, há um efeito relativamente intermediário nos tempos do pretérito perfeito e presente sem neutralização (com todos os dados $=0,45$; sem os casos categóricos $=0,41$ ), e há o desfavorecimento de a gente no imperfeito $(0,36)$ e pretérito perfeito com neutralização $(0,23)$. Por isso, podemos citar os resultados de apenas uma análise que, no caso, é a análise sem os casos categóricos.

Pela hipótese inicial, o presente e o pretérito imperfeito favorecerem a gente para evitar, sobretudo, as proparoxítonas. Apenas o tempo presente favorece a gente, porque os pretéritos perfeitos e imperfeitos estão abaixo da média. Nessa análise, retiramos os poucos dados de futuro do pretérito, presente do subjuntivo, futuro do subjuntivo e imperfeito do subjuntivo.

Esses resultados são bem diferentes dos resultados de Mattos (2013), que pesquisou a alternância e concordância de primeira pessoa do plural na fala urbana de Goiás. Em sua amostra, o imperfeito favorece o uso de a gente justamente para evitar a formação das proparoxítonas. No entanto, deve-se levar em conta que os entrevistados de Aceguá são da parte urbana, que compõe cerca de $20 \%$ do território de Aceguá, mas que também é bem influenciada pela grande maioria da zona rural. Também há muitos dados de "nós falava", o que segue o princípio do "evite proparoxítona" e sem a necessidade da inserção de $a$ gente. 
Na variável tempo e paradigma verbal, uma das oposições contundentes também está no presente com neutralização favorecendo a gente (de 0,68 a 0,74 ) e no pretérito perfeito com neutralização desfavorecendo a gente (0.23). Isso indica, na alternância pronominal, que a gente fala é mais favorecido do que nós falamos, quando presente; nós falamos é mais favorecido do que a gente falou, também por causa da frequência de nós falemo. Como falamo(s) e falemo(s) têm o mesmo morfema de plural -mos, essa desinência é sempre associada ao pronome nós, uma vez que não há dados de a gente vamos no corpus de Aceguá. Assim, -mos também tende a se especializar como pretérito quando há possibilidade de neutralização no presente e no passado.

Quando não há neutralização, não existe oposição entre pretérito perfeito e presente, ambos com peso relativo idêntico de 0,41, ou seja, apresentam efeito relativamente intermediário, com tendência ao desfavorecimento de a gente, tendo em vista o efeito do presente com neutralização $(0,74)$ e o pretérito perfeito com neutralização $(0,23)$ em polos opostos, favorecedor e desfavorecedor de a gente.

O imperfeito $(0,36)$ desfavorece a gente e, complementarmente, favorece nós. Aqui, então, a diferença é que se evita proparoxítona na fronteira com a forma "nós falava" junto com "a gente falava" em detrimento de "nós falávamos". Dos 80 casos de imperfeito, na análise de brasileiros e uruguaios sem os casos categóricos de nós, há 43,8\% (35 dados) de a gente e 56,2\% (45 dados) de nós, ou seja, há mais dados de nós. O fato é que "nós falava", na fronteira, também por ter influência rural, parece não ter a rejeição que há nas amostras mais urbanas do português brasileiro, exceto no Goiás.

Para o tipo de referência, apenas na análise sem os dados categóricos essa variável foi selecionada. $\mathrm{O}$ contexto mais genérico favorece o pronome a gente $(0,55)$ em detrimento do contexto mais específico $(0,43)$ conforme a hipótese inicial. Para a análise com todos os colaboradores, reproduzimos o nível de significância em que essa variável poderia ser selecionada, mas com o nível de 0,181 há pouca probabilidade de seleção.

De qualquer forma, o pequeno favorecimento de 0,55 nos dá indícios de que a diferença da referência pode estar se diluindo, mesmo porque o pronome a gente está se expandindo cada vez mais para outros contextos. Um exemplo dessa expansão é o sentido de "eu", pronome bem específico, particular e determinado, para o pronome $a$ gente, que diacronicamente aparece na língua como um sintagma indeterminado. Ainda assim, os contextos genéricos ou indeterminados favorecem o uso de a gente nos nossos dados sincrônicos. 
A retirada de a gente e nós com sentido de primeira pessoa do singular "eu" foi motivada pelo fato de que esses dados alternam com "eu" e não com nós, além de serem uma estratégia de esquiva para ocultar a primeira pessoa. Quando rodávamos juntos, a significância era de mais de 0,96, ou seja, quase categórico. Talvez isso pudesse influenciar na seleção da variável e, além disso, não dava convergência em todas as análises comparativas. Não há registros de que outros trabalhos sobre nós e a gente tenham feito essa opção de retirar os dados de a gente com sentido de "eu". Normalmente, o que se encontra nas pesquisas é o controle estatístico desse fator.

A variável linguística função sintática foi retirada da análise estatística para priorizar os pronomes em função de sujeito, mesmo porque quando rodados em todas as funções sintáticas o programa aponta para a não convergência e temos de ter análises semelhantes para manter o princípio da comparabilidade dos resultados.

Em suma, das variáveis que condicionam o fenômeno da alternância nós e a gente como primeira pessoa do plural, percebe-se que o padrão linguístico que favorece o uso do pronome a gente é (i) sujeito explícito $(0,59)$; (ii) quando é precedido de a gente explícito ou implícito $(0,84$ e 0,88$)$, corroborando a eficácia também do paralelismo linguístico; (iii) a gente como referência genérica $(0,55)$ apenas na análise sem os casos categóricos; e (iv) com o tempo verbal do presente com neutralização (0.74) e as formas nominais do gerúndio e infinitivo (0.56).

Com relação aos fenômenos sociais, é importante recordar que os jovens (0.74) lideram a mudança linguística, sendo, portanto, os responsáveis pelo alto uso de a gente como pronome de primeira pessoa do plural na comunidade de Aceguá como um todo, o que inclui brasileiros e uruguaios.

Depois dos resultados sociais e linguísticos dos uruguaios e brasileiros (amostra completa), fica claro que o comportamento linguístico da escolha de uma variante em detrimento da outra não é tão diferente na comunidade como um todo, especialmente pelo fato de a nacionalidade ter sido selecionada apenas na análise com todos os dados, com o peso relativo de 0,62 . No entanto, na análise sem os casos categóricos, a nacionalidade não é mais selecionada estatisticamente, o que corrobora o fato de uma maior neutralização na comunidade que de fato varia entre nós e a gente como primeira pessoa do plural. Esse resultado nos autoriza a rodar os dados juntos de ambos os lados da fronteira. 
Posto isso, partimos para análises mais específicas dos monolíngues em português (brasileiros) e dos bilíngues em português e espanhol (uruguaios) separadamente a fim de identificar especificidades e semelhanças.

\subsection{Análise dos resultados apenas dos uruguaios}

Nessa seção, fizemos uma análise apenas com os uruguaios de Aceguá, no intuito de identificar padrões comuns e divergentes da comunidade e dos próprios brasileiros do outro lado da fronteira. Uma das questões de pesquisa é justamente saber o que condiciona o uso de nós e a gente no português falado pelos uruguaios bilíngues. Nesse rearranjo do Quadro 7, excluindo os brasileiros, temos a seguinte configuração social:

Quadro 7: Distribuição dos colaboradores uruguaios

\begin{tabular}{|c|c|}
\hline FAIXA ETÁRIA & Uruguaios \\
\hline 15 a 30 anos & 3 homens \\
& 4 mulheres \\
\hline 31 a 49 anos & 6 mulheres \\
\hline Acima de 50 anos & 2 homens \\
& 4 mulheres \\
\hline Total & 19 colaboradores \\
\hline
\end{tabular}

O fato de só haver mulheres na célula de 31 a 49 anos não significa um problema em si para a análise estatística, porque a interação aqui não é total, uma vez que as outras células estão mais equilibradas. De acordo com Guy e Zilles (2007, p. 52),

os grupos de fatores devem ser "ortogonais" ou quase "ortogonais". Isto é, eles devem co-ocorrer livremente" [...], mas, frequentemente, esse ideal não é atingido. Então, temos de nos defrontar com a questão de até que ponto podemos nos desviar desse padrão e ainda obter resultados válidos.

Por isso, ainda segundo Guy e Zilles (2007, p. 59-60), a assimetria na distribuição dos dados pode ocasionar sobreposição, mas "uma sobreposição de $90 \%$ é tolerável, ainda que se deva reconhecer que algumas distorções dos resultados provavelmente estejam ocorrendo; [...] 95\% de sobreposição é, provavelmente, o limite absoluto de capacidade de análise razoável”. Apenas quando há interação completa, de 100\%, ou seja, distribuição complementar, o Varbrul não é apropriado para a análise (GUY e ZILLES, 2007, p. 54-55). 
Em termos de distribuição dos dados, a percentagem global do fenômeno está bem mais abaixo do que na análise de brasileiros e uruguaios, que registrava cerca de $45,9 \%$ de uso de a gente como primeira pessoa do plural. Na análise do português uruguaio, essa frequência cai para $29,3 \%$ com todos os dados e aumenta significativamente para 49,1\% na análise sem os casos categóricos, conforme mostra a Tabela 5.

Tabela 5: Percentagem global das variantes a gente e nós na posição de sujeito do português uruguaio da amostra de Aceguá

\begin{tabular}{l|c|l}
\hline & \multicolumn{2}{|c}{ Colaboradores } \\
\hline Variantes & Com todos & Sem os categóricos de nós \\
\hline A GENTE & $135 / 461=29,3 \%$ & $135 / 275=49,1 \%$ \\
\hline NÓS & $326 / 461=70,7 \%$ & $140 / 275=50,9 \%$ \\
\hline
\end{tabular}

A variável social selecionada pelo Goldvarb foi a faixa etária. Já as variáveis linguísticas foram as mesmas da análise com brasileiros e uruguaios: preenchimento do sujeito, paralelismo linguístico e tempo/saliência. Não foram selecionadas como estatisticamente significativas as variáveis sexo e tipo de referência.

No caso das variáveis sociais, a escolaridade foi excluída da análise porque só há colaboradores uruguaios com ensino médio. Já a nacionalidade foi retirada, porque agora queremos apenas os dados de uruguaios.

A função sintática foi a variável linguística eliminada da análise de peso relativo, porque optamos por rodar apenas dados na função de sujeito para efeitos de comparabilidade com todas as análises, uma vez que essa variável não dava convergência. A concordância de número foi novamente excluída da análise final, porque na concordância de número só há variação quando não há sujeito explícito e a concordância está no singular, ou seja, a concordância variável só ocorre com nós.

$\mathrm{Na}$ identificação do colaborador, é possível entender as variações idioletais. Por meio dessa variável, foi possível identificar que não houve variação na fala de todos os uruguaios entrevistados. Alguns jovens, especialmente, foram categóricos no uso de nós como primeira pessoa do plural, como veremos na próxima seção, em que analisamos as variáveis sociais e linguísticas que condicionam o fenômeno variável de primeira pessoa do plural no português uruguaio. 


\subsubsection{Variáveis sociais}

O sexo não foi selecionado na análise apenas com os uruguaios. No caso da faixa etária, houve uma mudança significativa, porque, enquanto na análise conjunta de toda a fronteira os jovens favoreciam o uso do pronome a gente, na análise dos uruguaios são os adultos os propagadores do pronome inovador quando a análise inclui todos os falantes uruguaios. Quando os falantes categóricos no uso do nós são retirados, os jovens voltam a favorecer grandemente o pronome a gente com 0,81 , no mesmo padrão de mudança linguística do português brasileiro da fronteira em que jovens favorecem a variante inovadora e os demais falantes desfavorecem-na, conforme mostra a Tabela 6.

Tabela 6: Efeito das variáveis sociais em relação ao pronome a gente no português uruguaio na amostra de Aceguá

\begin{tabular}{|c|c|c|c|c|c|c|}
\hline \multirow[b]{3}{*}{ Variáveis sociais } & \multicolumn{6}{|c|}{ Colaboradores } \\
\hline & \multicolumn{3}{|c|}{ Com todos } & \multicolumn{3}{|c|}{ Sem os categóricos de nós } \\
\hline & $\begin{array}{c}\text { N de dados/ } \\
\text { Total }\end{array}$ & $\begin{array}{c}\text { Percen- } \\
\text { tagem }\end{array}$ & Peso & $\begin{array}{c}\text { N de dados/ } \\
\text { Total }\end{array}$ & $\begin{array}{l}\text { Percen } \\
\text {-tagem }\end{array}$ & Peso \\
\hline \multicolumn{7}{|l|}{ Faixa etária } \\
\hline 15 a 30 anos & $41 / 159$ & $25,8 \%$ & 0,44 & $41 / 52$ & $78,8 \%$ & 0,81 \\
\hline 31 a 49 anos & $62 / 148$ & $41,9 \%$ & 0,63 & $62 / 127$ & $48,8 \%$ & 0,42 \\
\hline Acima de 50 anos & $32 / 154$ & $20,8 \%$ & 0,43 & $32 / 96$ & $33,3 \%$ & 0,40 \\
\hline \multicolumn{7}{|l|}{ Sexo } \\
\hline Mulher & $101 / 288$ & $35,1 \%$ & {$[0,47]$} & $34 / 102$ & $33,3 \%$ & {$[0,64]$} \\
\hline Homem & $34 / 173$ & $19,7 \%$ & {$[0,53]$} & $101 / 173$ & $58,4 \%$ & {$[0,26]$} \\
\hline Total & $135 / 461$ & $29,3 \%$ & & $135 / 275$ & $49,1 \%$ & \\
\hline Input & & & 0,18 & & & 0,50 \\
\hline
\end{tabular}

Com base nos resultados da faixa etária, é curioso notar que o comportamento linguístico dos jovens e adultos se inverte em ambas as análises. $\mathrm{Na}$ análise de uruguaios com todos os colaboradores, os adultos direcionam a mudança linguística favorecendo o uso de a gente com 0,63 de peso relativo, enquanto os jovens desfavorecem esse mesmo uso com 0,44 . No entanto, o padrão etário de mudança clássica emerge na análise uruguaia sem os casos categóricos, quando os adultos (31 a 49 anos) desfavorecem a gente com 0,42 e os jovens favorecem o uso de a gente com 0,81 de peso relativo, refletindo o padrão sociolinguístico esperado para a mudança linguística pronominal.

Sobre a variável sexo, no nível em que ela poderia ter sido selecionada na análise com todos os colaboradores, a significância é de 0,492 , ou seja, probabilidade remota de 
seleção. Os pesos relativos também refletem certa neutralidade, que não passa de 0,53 (homem) e nem abaixa mais de 0,47 (mulher). Na análise sem os casos categóricos, o último nível de significância é de 0,094, com grandes chances de ser selecionada, mesmo com a presença da faixa etária. Assim, percebe-se que o desequilíbrio da célula de 31 a 49 anos, por só ter mulheres, não é a responsável direta pela não seleção do sexo, ainda que tenha certa influência, como evidencia a Tabela 7.

Tabela 7: Peso relativo da variável sexo em cada nível de significância do português uruguaio

\begin{tabular}{|c|c|c|c|c|c|c|}
\hline & \multicolumn{6}{|c|}{ Colaboradores } \\
\hline & \multicolumn{3}{|c|}{ Com todos } & \multicolumn{3}{|c|}{ Sem os categóricos de nós } \\
\hline Níveis de significância & Mulher & Homem & $\begin{array}{l}\text { Signifi- } \\
\text { cância }\end{array}$ & Mulher & Homem & $\begin{array}{l}\text { Signifi- } \\
\text { cância }\end{array}$ \\
\hline Nível 0 & & & $\begin{array}{l}0,293 \\
\text { Input }\end{array}$ & & & $\begin{array}{l}0,491 \\
\text { Input }\end{array}$ \\
\hline Nível 1 - Sexo & {$[0,57]$} & {$[0,37]$} & 0,000 & {$[0,59]$} & {$[0,34]$} & 0,000 \\
\hline $\begin{array}{l}\text { Níve } 2-\text { Sexo e } \\
\text { paralelismo }\end{array}$ & {$[0,53]$} & {$[0,44]$} & 0,200 & {$[0,55]$} & {$[0,41]$} & 0,064 \\
\hline $\begin{array}{l}\text { Nível } 3 \text { - Sexo, } \\
\text { preenchimento do sujeito e } \\
\text { paralelismo }\end{array}$ & {$[0,52]$} & {$[0,45]$} & 0,292 & {$[0,55]$} & {$[0,41]$} & 0,078 \\
\hline $\begin{array}{l}\text { Nível } 4 \text { - Sexo, } \\
\text { preenchimento do sujeito, } \\
\text { tempo verbal e paralelismo }\end{array}$ & {$[0,52]$} & {$[0,45]$} & 0,328 & {$[0,54]$} & {$[0,42]$} & 0,191 \\
\hline $\begin{array}{l}\text { Nível } 5 \text { - Sexo, Faixa } \\
\text { etária, preenchimento do } \\
\text { sujeito, tempo verbal e } \\
\text { paralelismo }\end{array}$ & {$[0,47]$} & {$[0,53]$} & 0,492 & {$[0,64]$} & {$[0,26]$} & 0,094 \\
\hline
\end{tabular}

A análise uruguaia sem os casos categóricos de nós não apresenta convergência no último nível do step-up (nível 5), o que ocasiona uma desordem nos resultados da faixa etária, pois os falantes de mais idade $(0,64)$ e os jovens $(0,77)$ favoreceriam a gente em detrimento dos adultos $(0,28)$, padrão este nunca identificado em nenhuma outra análise. $\mathrm{E}$ as mulheres favoreceriam a gente com 0,64 em detrimento dos homens com 0,26. Certamente é "a prova dos nove" para que a variável sexo não seja mesmo selecionada, ainda que o nível de significância tenha saído de 0,191, no nível anterior (nível 4), e melhorado para 0,094, mesmo com a entrada da faixa etária. O último nível do step-up mostra os pesos relevantes das variáveis se todas elas tivessem sido selecionadas. Segundo Scherre e Naro (2004, p. 165),

O programa estatístico trabalha com "níveis diversos de análise, efetuando comparações sucessivas e progressivas entre as variáveis independentes e projetando pesos relativos para os seus respectivos valores. Este método, denominado de step up, inicia-se no nível zero, com a projeção do input, 
efetua no nível 1 a comparação de cada uma das variáveis com a média global corrigida ou input, e trabalha sucessivamente até que as variáveis independentes adicionadas não sejam mais selecionadas, isto é, não tenha relevância estatística".

Assim, o step-up é um método utilizado para selecionar as variáveis estatisticamente significativas a cada nível. O teste individual dos grupos de fatores é feito adicionando-os de um por um e comparando-os com o nível 0. Continua funcionando dessa maneira até não haver mais seleção de variáveis estisticamente significativas. Esses níveis de análise permitem identificar se há alguma interferência entre as variáveis (TAGLIAMONTE, 2006, p. 140).

Se "não ocorre sobreposição, os pesos relativos do primeiro nível permanecem semelhantes até o último nível da análise. Essa é a situação linguística e matematicamente ideal, mas nem sempre constitui a realidade dos fatos" (SCHERRE e NARO, 2004, p. 166). Para os autores, é justamente para equilibrar essa situação que existe a sofisticação matemática na análise dos dados e o cálculo de peso relativo, além das frequências.

Quando as hipóteses sociais tipicamente labovianas não são confirmadas, é importante olhar o indivíduo, porque a transição de uma forma linguística a outra pode ser melhor analisada a partir da identificação do comportamento linguístico que cada colaborador tem, isoladamente. Por isso, torna-se importante estudar também o idioleto, por ser o indivíduo, às vezes, o representativo de determinada mudança linguística, e não a comunidade como um todo.

Portanto, somente foi possível identificar diferença etária a partir do controle individual da identificação do colaborador. Dos 19 colaboradores uruguaios desse corpus, 4 jovens (dos sete no total), 2 adultas (das seis no total) e 2 idosas (dos seis no total) usam categoricamente em sua fala o pronome nós, ou seja, $42 \%$ dos entrevistados uruguaios (8 pessoas) não variam o pronome de primeira pessoa do plural em sua fala. O Quadro 8 ilustra o corpus dos colaboradores uruguaios.

Quadro 8: Distribuição dos colaboradores uruguaios entre a fala categórica em nós e a fala variável

\begin{tabular}{|c|c|c|c|c|c|}
\hline \multirow{2}{*}{ Faixa etária } & \multicolumn{2}{|c|}{ Fala categórica em nós } & \multicolumn{2}{c|}{ Fala variável } & \multirow{2}{*}{ Total geral } \\
\cline { 2 - 5 } & Mulher & Homem & Mulher & Homem & \\
\hline 15 a 30 anos & 2 & 2 & 2 & 1 & 7 \\
\hline 31 a 49 anos & 2 & ---- & 4 & ----- & 6 \\
\hline Acima de 50 anos & 2 & ---- & 2 & 2 & 6 \\
\hline Total & 6 & 2 & 8 & 3 & 19 \\
\hline
\end{tabular}


No caso dos uruguaios que usam categoricamente o nós, não há variação em nível individual, mas há algumas semelhanças com relação aos fatores sociais. Da faixa etária mais jovem, quatro pessoas concentram-se mais na categoricidade do uso de nós como pronome de primeira pessoa do plural em detrimento de três pessoas que variam entre nós e a gente. O contrário acontece com os adultos, dos quais duas pessoas usam categoricamente nós e 4 pessoas apresentam comportamento linguístico variável. Dos falantes acima de 50 anos, dois usam categoricamente nós e quatro variam entre nós e a gente. De acordo com Guy e Zilles (2006, p. 127),

Estatisticamente, é de se esperar que, quando há pequenas flutuações nos dados, um informante se desvie da tendência do grupo, num momento, numa certa direção e depois outro, em outra direção; a soma de vários indivíduos juntos normalmente tende a anular ou reduzir o desvio total para o grupo.

Assim, como quase metade dos falantes uruguaios não utilizou a gente nas entrevistas, foi de suma importância analisar os efeitos categóricos desses colaboradores e as motivações ou possíveis interpretações para esse comportamento linguístico categórico que poderia interferir no comportamento geral do grupo, conforme pode ser visto na Tabela 8.

Tabela 8: Percentagem de uso do pronome a gente na fala dos colaboradores uruguaios

\begin{tabular}{l|l|l}
\hline Identificação dos colaboradores uruguaios & $\begin{array}{l}\text { Número de } \\
\text { dados/Total }\end{array}$ & Frequência \\
\hline TAT, de 31 a 49 anos, ensino médio & $8 / 8$ & $100 \%$ \\
\hline VAL, de 15 a 30 anos, ensino médio & $22 / 23$ & $95,7 \%$ \\
\hline OUT, de 15 a 30 anos, ensino médio & $17 / 23$ & $73,9 \%$ \\
\hline ROT, de 31 a 49 anos, ensino médio & $45 / 76$ & $59,2 \%$ \\
\hline MAR, de 31 a 49 anos, ensino médio & $7 / 15$ & $46,7 \%$ \\
\hline ALE, acima de 50 anos, ensino médio & $30 / 72$ & $41,7 \%$ \\
\hline ALX, de 15 a 30 anos, ensino médio & $2 / 6$ & $33,3 \%$ \\
\hline JAQ, acima de 50 anos, ensino médio & $1 / 5$ & $20 \%$ \\
\hline CAR, acima de 50 anos, ensino médio & $2 / 24$ & $8,3 \%$ \\
\hline VAN, de 31 a 49 anos, ensino médio & $1 / 14$ & $7,1 \%$ \\
\hline JEF, de 15 a 30 anos, ensino médio & $0 / 68$ & $0 \%$ \\
\hline FLO, de 15 a 30 anos, ensino médio & $0 / 34$ & $0 \%$ \\
\hline MAI, acima de 50 anos, ensino médio & $0 / 30$ & $0 \%$ \\
\hline ESP, acima de 50 anos, ensino médio & $0 / 25$ & $0 \%$ \\
\hline KEL, de 31 a 49 anos, ensino médio & $0 / 21$ & $0 \%$ \\
\hline MAE, de 31 a 49 anos, ensino médio & $0 / 9$ & $0 \%$ \\
\hline JUD, acima de 50 anos, ensino superior & $0 / 3$ & $0 \%$ \\
\hline MAU, de 15 a 30 anos, ensino médio & $0 / 3$ & $0 \%$ \\
\hline FIL, de 15 a 30 anos, ensino fundamental & $0 / 2$ & $0 \%$ \\
\hline TOTAL & $135^{91} / 461$ & $29,3 \%$ \\
\hline
\end{tabular}

${ }^{91}$ Total com base nos resultados da análise uruguaia. 
Por conta dos poucos dados de alguns colaboradores e dos casos categóricos, que podem interferir nos resultados, fizemos outra análise retirando os categóricos em nós (os nove últimos falantes da Tabela 8). Analisando as entrevistas uruguaias e os fatores sociais de cada colaborador, podemos interpretar que os quatro jovens que somente utilizam o pronome nós podem ser mais conservadores que os adultos por alguns motivos que serão listados adiante. Há também três pessoas acima de 50 anos e duas adultas e nenhum desses 9 colaboradores uruguaios utiliza o pronome a gente. Os dois uruguaios (TAT e VAL) que utilizam a gente acima de 95\% também haviam sido retirados da análise, mas, como não houve diferenças significativas, esses dados foram mantidos.

Os jovens que usam categoricamente o nós (JEF, FLO, MAU, FIL), quando estudam e trabalham fora do comércio e do campo, buscam oportunidades em outros lugares. Normalmente, os jovens que ficam em Aceguá são mais apegados às raízes culturais e à forma de viver local. Muitas vezes, são bem tradicionalistas e se envolvem mais com as questões do campo ou do comércio local, em instâncias e estabelecimentos familiares.

Nesse sentido, há menos interação com brasileiros fora de Aceguá, e os contextos sociais são restritos, ou seja, a mobilidade social e urbana também é reduzida. Os quatro jovens de comportamento linguístico categórico, por exemplo, nunca saíram da fronteira. Por isso, também, o uso da variante conservadora nós é mais produtivo entre eles, especialmente porque é a correspondência fiel do pronome nosotros no espanhol, variedade linguística de maior convivência entre esses jovens se compararmos com a variedade do português brasileiro.

Os fatores sociais fazem parte da explicação dessa mudança linguística, especialmente porque partimos do pressuposto de que o pronome a gente é induzido pelo contato com a variedade do português brasileiro, ou seja, a aquisição de a gente é consequência do contato linguístico com o português brasileiro. Ao que tudo indica, a realidade e a identidade desses jovens são mais enraizadas no Uruguai e na fronteira, por isso, talvez, a categoricidade de uso de nós em 8 uruguaios dos 19 entrevistados. Conforme preconiza Labov (2008, p. 342), a identidade local é motivo para adotar e avançar uma inovação, porque

além dos condicionamentos entrecruzados de classe social e casta, as comunidades frequentemente desenvolvem categorias mais concretas para situar os indivíduos. Em comunidades rurais (ou em bairros periféricos), a 
identidade local é uma categoria de pertencimento extremamente importante - muitas vezes, impossível de reivindicar e difícil de conquistar.

Assim, no caso dos jovens que não usam a gente, não têm contato com o Brasil ou não desenvolveram um sentimento de identificação com a cultura brasileira da fronteira, não há motivo para adotar e avançar no uso do pronome $a$ gente. O que acontece é uma espécie de refreio da mudança no sentido de uma preferência em usar a forma mais antiga (nós), tal como aconteceu no caso de Martha's Vineyard.

Nessa ilha estudada por Labov, a centralização dos ditongos tem um significado para os vineyardenses, pois o falante está "inconscientemente expressando o fato de que pertence à ilha: de que ele é um dos nativos a quem a ilha realmente pertence." (LABOV, 2006, p. 57). Esse fenômeno se deu também mais forte nas faixas etárias mais jovens como acontece com nosso corpus em Aceguá. Assim, presume-se que a identidade desses jovens e o significado social das variantes nós e a gente influenciam no sentido de sobressair o uso do nós entre eles.

Em contrapartida, os adultos uruguaios e os jovens que usam a gente têm maior mobilidade social e geográfica, trabalham fora de Aceguá e têm mais contato com brasileiros além da fronteira. Talvez isso explique a preferência pelo uso de a gente, já que é uma variante inovadora. É a diversidade de práticas e de atividades sociais - ter experiência de vida, ter saído da fronteira e viajado para outros lugares, trabalhar fora de casa, participar de redes sociais mais amplas, fora do ambiente apenas familiar - que propicia diferentes práticas sociais vividas por eles.

No exemplo a seguir, um desses jovens uruguaios, de comportamento linguístico categórico com relação ao uso de nós, relata como sua vida é voltada para o Uruguai e para os contextos mais familiares.

Entrevistador: É. Deve ser por aí. E como é viver aqui na fronteira? Entrevistado: Pá mim, eu gosto. Eu tenho saído por todo esse lado do Uruguai, porque no que NÓS TRABALHEMO é viajar, porque NÓS TEMO, NÓS CUIDEMO cavalo pá hipismo. E aí VIAJAMO por todos esses lugar do Uruguai, por todos esses povo, cidade. E eu gosto, gosto de Aceguá, tenho uma liberdade bárbara.

Entrevistador: E aqui é tranquilo né?

Entrevistado: É tranquilo, tu pode largar um guri pá qualquer lado que não tem... não passa nada.

Entrevistador: Pois é, super tranquilo. $\mathrm{E}$ tu conhece o que do Uruguai?

Entrevistado: Do Uruguai eu conheço um monte de povinho, de cidade assim, porque eu acho é difícil, no Brasil não tem Raí, que NÓS FALEMO aqui, que é hipismo tipo enduro, no Brasil, enduro, só que em carretera, NÓS CORREMO sessenta, noventa quilômetros em quinze, em duas etapas, e CORREMO valendo prêmio por isso.

$[\ldots]$ 
Entrevistador: $\mathbf{E}$ tu conhece muita coisa aqui no Brasil, muito lugar aqui no Brasil também?

Entrevistado: Brasil, eu te digo que não conheço Bagé.

Entrevistador: Ah é?

Entrevistado: Não por... por não querer ir ....

Entrevistador: É mesmo?

Entrevistado: Tinha ido jogar na Colônia, não sei se tu conhece, na Colônia, na Colônia, campeonato sete, SAÍMO campeão último ano.

Entrevistador: Futebol?

Entrevistado: Sim, futebol sete. Fui na Colônia, mas NÓS IA de noite e VOLTAVA. Eu não sou muito... agora o meu tio dil: vai, vai pra Bagé, VAMO sair lá, VAMO ver agora fim de tempo né.

Entrevistador: Tua vida é mais aqui no Uruguai né?

Entrevistado: Sim. Claro e que passa, no caso, NOSSO, os Raí aqui são de nove meses, de março a novembro.

Entrevistador: Nossa, puxado né?

Entrevistado: Sim. E janeiro, fevereiro e março TEMO TREINANDO, e dezembro, TEMO TREINANDO agora. É o ano inteiro.

Entrevistador: Envolvido né?

Entrevistado: E pede cavalo, tens que ta na volta dele. Mas, agora NÓS PASSAMO o verão inteiro, era variando, era as duas as três da tarde, varia, que varia, varia, com aquele sol. Eu já ponteava meu pai, dizia: eu não faço mai. E na UTO, as guria não levaram?

(JEF, homem, de 15 a 30 anos, uruguaio, ensino médio)

O jovem aceguaense nasceu, mora, sempre trabalhou na parte uruguaia e nunca viajou para o Brasil, sequer a Bagé, localidade brasileira mais próxima de Aceguá, com distância de apenas $60 \mathrm{~km}$. Como ele participa de competições de cavalo, o trabalho dura normalmente 9 meses corridos no Uruguai. Esse é um exemplo de um jovem que somente utiliza nós como pronome de primeira pessoa do plural.

Os entrevistados MAU e FIL já falam pouco e sempre respondem apenas ao que o entrevistador pergunta, não prolongando a conversa. Também houve pouquíssimos dados de primeira pessoa do plural porque eles se referiam mais a eles. No caso de FLO, ela não tem dupla nacionalidade, toda a família é uruguaia, só estudou no Uruguai, mas trabalha no Brasil e namora um brasileiro. Usa o espanhol no trabalho e em casa, mas fala predominantemente português. É possível ver semelhanças linguísticas entre os colaboradores FLO e JEF, principalmente com relação à concordância verbal que termina com -emo.

Entrevistador: E com quem você fala espanhol, com quem você fala português?

Entrevistado: Bah, quando eu tenho que falar espanhol, é muito. Agora, no caso, estão fazendo no Uruguai o censo. E eu peguei pra trabalhar. Então, agora, semana que vem NÓS COMECEMO, e o meu espanhol era um espanhol só em casa, e quando vem algum primo meu uruguaio. E nada mas. Entrevistador: Em casa você fala em espanhol?

Entrevistado: Sim, algumas vezes sim. No caso com o meu cunhado que fala espanhol.

Entrevistador: Ele não fala português? 
Entrevistado: Fala. Aqui todo mundo fala.

Entrevistador: Todo mundo fala?

Entrevistado: Sim. E no caso, aqui como eu trabalho no comércio, aqui NÓS DEPENDEMO dos quilheiro, dos uruguaios, aí NÓS FALEMO espanhol.

Entrevistador: E os quilheiros não falam português não né?

Entrevistado: Algum. São completamente, o espanhol é que chega a ser...

Entrevistador: E tu acha que fala mais português ou mais espanhol?

Entrevistado: Sim, mais português.

Entrevistador: E tu prefere falar português ou espanhol? Assim, você se sente mais a vontade falando qual?

Entrevistado: Português. Claro, eu nunca saí daqui, mas quando vai por aí, Bueno, tá, tem algumas palavras que NÓS até se ENROLEMO. E mesmo escrever. Escrever, eu nunca fiz nenhum curso em português, e sei, de ler, jornal, revistas. Porque aqui é muito raro ter um jornal ou algo do Uruguai. Aí NÓS LEMO tudo brasileiro. E no caso, a televisão também. Agora NÓS TEMO cable que tem canal uruguaio. Mas senão pega só a parabólica, e tem só canal brasileiro.

Entrevistador: A Globo né?

Entrevistado: Hum hum. Direto.

(FLO, mulher, de 15 a 30 anos, uruguaia, ensino médio)

Após identificar traços sociais comuns nos jovens uruguaios de comportamento linguístico categórico com relação ao uso de nós, a interpretação para esse resultado pode estar também no fato da distância que eles mantêm das práticas sociais brasileiras e da identidade forte que mantêm com o Uruguai. É a realidade e a vivência dos indivíduos, bem como sua participação efetiva em práticas sociais variadas e os bens culturais a que têm acesso, que podem determinar os usos linguísticos do indivíduo ou da comunidade.

Por outro lado, é também fundamental analisar os traços sociais também dos jovens uruguaios de comportamento variável. Posto isso, analisaremos duas jovens uruguaias, mulheres e com ensino médio que têm alto índice de a gente em sua fala: (i) VAL com $95,7 \%(22 / 23)$ de $a$ gente; e (ii) OUT com 73,9\% (17/23) de a gente.

VAL é uruguaia, nasceu em Melo, mas mora do lado do Brasil, já viajou para outras fronteiras, namora uma pessoa de fora, e foi para o Brasil com 3 anos. É a única uruguaia da turma na escola brasileira, inclusive não pôde fazer ENEM por não ser brasileira. Estudou no Uruguai até 10 anos quando começou a aprender português na escola brasileira. Teve muita dificuldade porque só falava espanhol. A mãe mora atualmente com um brasileiro, mas não é casada oficialmente, por isso ela não conseguiu a dupla-nacionalidade ainda. Depois desse casamento da mãe, começou a falar mais português, juntamente com sua entrada na escola brasileira. Seu irmão, depois que foi estudar no Brasil, também passou a falar com ela em português. No entanto, a família toda é uruguaia e ainda mora no Uruguai. A mãe, pai, dois tios, tia, avó e bisavó só conversam em espanhol com ela. 
OUT se considera e tem os documentos de uruguaia e brasileira, filha de mãe uruguaia e pai brasileiro, fez todo o estudo no Uruguai e se identifica mais com o Brasil e com a cultura brasileira. A maior parte da família com quem tem contato é brasileira. Aprendeu português em casa, na televisão, e espanhol na escola. Por isso, falava português antes de entrar na escola e, quando começou a estudar no Uruguai, teve de aprender espanhol com bastante dificuldade.

Entrevistada: Sim. Por isso, mas eu falo os dois idiomas, tu veio me entrevistar como brasileira ou como uruguaia? Como uruguaia ou como brasileira?

Entrevistadora: Pois é. É justamente isso, como uruguaia, mas fala português, não?

Entrevistada: Sim, eu falo português.

Entrevistadora: Então, isso que é o interessante para a gente. O português que o uruguaio fala.

Entrevistada: Ah tá, claro. Porque eu falo en espanhol fluentemente, e falo português aqui como tu tá vendo que to falando agora né.

Entrevistadora: Fluente também né.

Entrevistada: Claro, só que o sotaque é diferente, e têm coisas que a gente... eu não sei te dizer algumas palavras, tipo, que eu não falo o português, eu falo o espanhol traduzido entende? Eu não sei te dizer alguma coisa mais.

Entrevistadora: Você não lembra de nenhum exemplo?

Entrevistada: Eu não sei te dizer alguma coisa, que eu digo, que eu falo e que não é. Vamos supor... não sei, não me lembro agora.

Entrevistadora: Mas assim, tu fala português com quem? Com quem você fala português e com quem você fala espanhol?

Entrevistada: Com a minha mãe eu falo em espanhol, com o meu pai eu falo em português. Com o meu namorado eu falo em português com ele. E com a Kelly eu falo em português, mas com o marido da Kelly eu me falo em espanhol. E se eu to falando, estamos os três, e eu to na metade da conversa, ya salto para espanhol, assim, sabe, dum pro outro. Tipo, porque se eu tá aqui sentada e ela tá ali né e estou aqui contando pra ela, tipo, ontem, ah eu fui para Minas, pero tava buenasso, digo pra ele. E ele sentado ali, entende? Assim é a conversa aqui nossa.

O grau de bilinguismo dessa jovem também é confirmado nesse outro trecho da entrevista:

Entrevistada: E a minha mãe é uruguaia.

Entrevistadora: Ela fala português?

Entrevistada: Ela fala, eu falo bem melhor que ela né. Porque vinte anos que ela mora com mo pai, vinte anos que ela fala português, mas dantes ela fala em espanhol. Eu falo melhor que ela, claro. Ela fala misturado. E o meu pai também, entre eles, ele fala em português ela responde em espanhol. E de vez em quando ele fala em espanhol com ela e ela responde em português.

Entrevistadora: Uau gente! Isso que eu acho muito legal. É interessante.

Entrevistada: sí, é así, E lá no meu serviço eu to conversando com os clientes, falo em espanhol porque eles son a maioria é do uruguaio né.

[...]

Entrevistada: Sim, não, é com todo mundo. Até hoje, sim. Os professores até que, por um lado, tratam de, como posso te dizer, tipo, quando estão na escola, que não falem o português, sabe? Claro, que não falem, que falem o 
espanhol, porque A GENTE, dizem até, estamos en el Uruguai, estamos falando espanhol. Mas não, os alunos, NÓS MESMOS, FOMOS agora com a Kelly aqui no Uruguai, que ela dava aula de computação e tudo, e as professora diziam: chiquilinas, saben el espanhol (00:10:00). Tipo, NÓS TAVA no Uruguai falando entre NÓS, claro, entre NÓS, em português.

Entrevistadora: Mesmo vocês sendo uruguaias né?

Entrevistada: Hum hum, claro. Português é o NOSSO... acho que entre toda a NOSSA turma assim, acho que muito poucos falam en espanhol.

Assim, a entrevistada é uruguaia e também brasileira, bilíngue, mas se identifica mais com o Brasil, trabalha e terminou os estudos do lado brasileiro, o que confirma a percentagem alta $(73,9 \%)$ de uso do pronome $a$ gente.

O padrão social desses jovens, que usam variavelmente nós e a gente, reflete uma maior aproximação com o Brasil, com a cultura brasileira e com práticas sociais brasileiras. Esse contato maior com aspectos socioculturais brasileiros também tipifica a alta frequência de a gente em termos de percentuais.

Com essa análise de uruguaios, é notório que a mudança linguística rumo ao uso de a gente como pronome de primeira pessoa do plural seria uma mudança coletiva, da comunidade uruguaia também, do ponto de vista dos falantes que usam variavelmente nós e a gente. Isso porque a faixa etária muda bruscamente com a retirada dos falantes categóricos de nós, retomando o padrão clássico da mudança linguística guiada pelos jovens.

O papel do indivíduo também é muito importante dentro das forças coletivas. Por isso, essa discussão será retomada no capítulo 6 (p. 262) sobre a identidade do indivíduo e da comunidade da fronteira. Resta discutir as variáveis linguísticas que também interferem no uso alternado dos pronomes.

\subsubsection{Variáveis linguísticas}

Exceto tipo de referência, as mesmas variáveis linguísticas selecionadas na análise de brasileiros e uruguaios foram selecionadas nessa análise de apenas uruguaios. A convergência nos resultados linguísticos também se deu, em certa medida, nos fatores de cada variável linguística, exceto com o tempo verbal do pretérito perfeito sem neutralização. Assim, o padrão linguístico permanece o mesmo em ambas as análises para a alternância dos pronomes nós e a gente em primeira pessoa do plural, sendo fatores condicionantes o preenchimento do sujeito, o tipo de referência e o paralelismo linguístico, conforme ilustra a Tabela 9. 
Tabela 9: Efeito das variáveis linguísticas em relação ao pronome a gente no português uruguaio da amostra de Aceguá

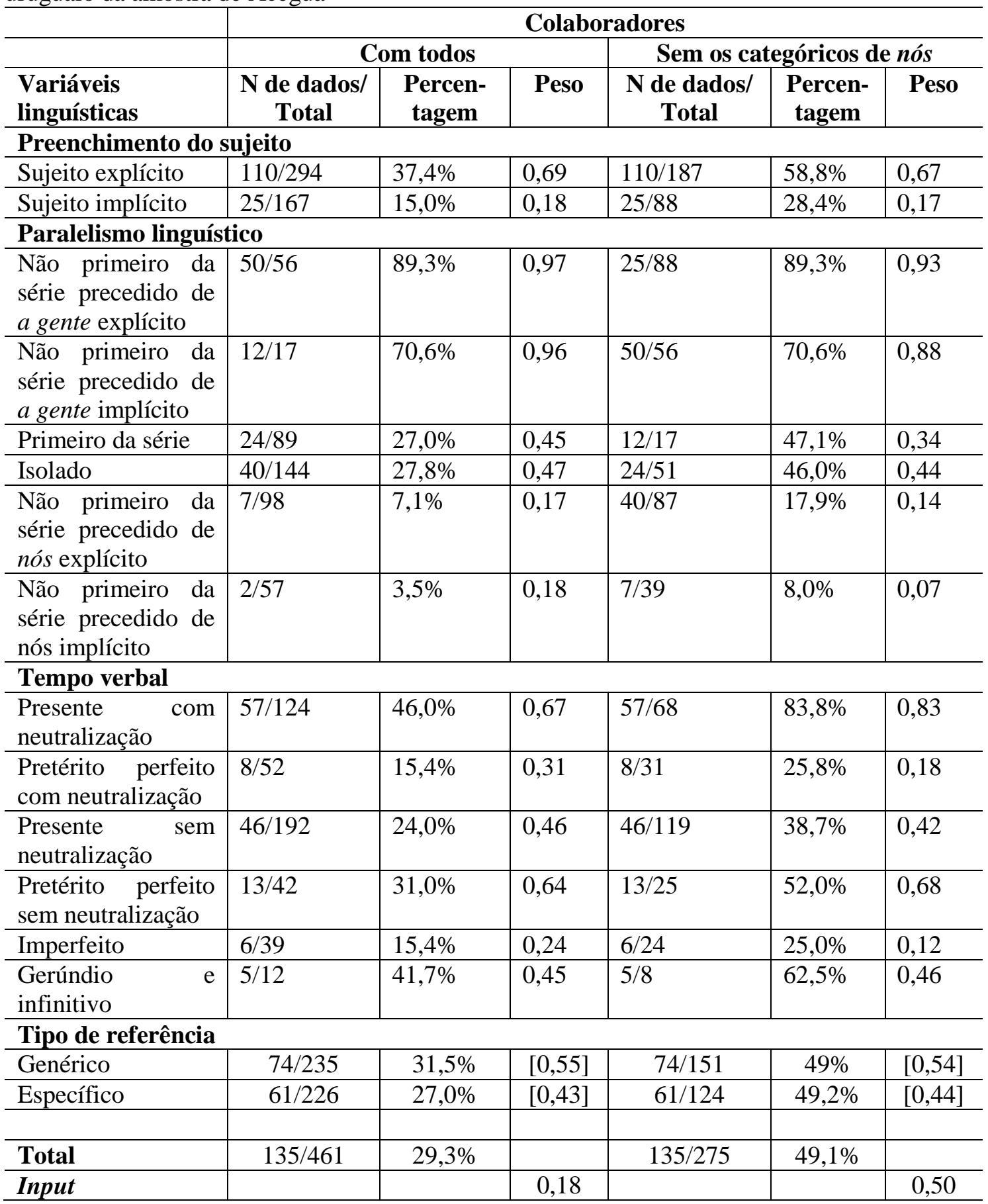

$\mathrm{Na}$ análise só com os dados dos uruguaios, como a análise geral de brasileiros e uruguaios, o preenchimento do sujeito continua favorecendo o uso do pronome $a$ gente quando o sujeito é explícito, seja com todos os colaboradores $(0,69)$, seja sem os casos categóricos $(0,67)$, o que faz todo sentido do ponto de vista funcional, pois sem flexão a gente tem de ser preenchido na função de sujeito. 
O paralelismo linguístico também é fator condicionante nessa análise, já que o efeito é desfavorecedor quando o uso de a gente é isolado $(0,47$ e 0,34$)$ ou o primeiro da série $(0,45$ e 0,44$)$, respectivamente para a análise com todos os colaboradores e sem os casos categóricos. Já o efeito favorecedor, de forma quase categórica, é da presença de $a$ gente quando precedido de a gente explícito $(0,97$ e 0,93$)$ ou implícito $(0.96$ e 0,88$)$, na análise com todos os colaboradores e sem os casos categóricos, respectivamente. Por outro lado, o pronome nós explícito $(0,17$ e 0,14$)$ ou implícito $(0,18$ e 0,07$)$ desfavorece bruscamente o pronome a gente também nos dois tipos de análise.

Para o tempo verbal/saliência fônica, há o favorecimento do presente com neutralização $(0,67$ e 0,83$)$ e do pretérito perfeito sem neutralização $(0,64$ e 0,68$)$. A diferença da análise uruguaia para a análise geral de brasileiro e uruguaio é que o favorecimento de a gente se inverte em dois tempos verbais. Agora, na análise uruguaia, é estatisticamente significativo o pretérito perfeito sem neutralização $(0,64$ e 0,68$)$ e passa a ter efeito relativamente intermediário o gerúndio e infinitivo $(0,45$ e 0,46$)$.

Os tempos que continuam desfavorecendo a gente são: imperfeito $(0,24$ e 0,12$)$ e pretérito perfeito com neutralização $(0,31$ e 0,18$)$. O presente sem neutralização $(0,46$ e 0,42 ) tem efeito relativamente intermediário. Lembrando que os primeiros valores dentro dos parênteses são da análise com todos os colaboradores, e os segundos valores são da análise sem os casos categóricos.

Novamente é importante mencionar que há mais dados de nós no imperfeito (84,6\% na análise com todos os colaboradores e $75 \%$ na análise sem os categóricos) do que a gente e há muitos dados de "nós falava", o que também evita proparoxítona. $\mathrm{O}$ pretérito perfeito com neutralização (nós falamo(s) ou nós falemo(s)) também tem praticamente a mesma quantidade de nós $(84,6 \%$ na análise com todos os colaboradores e $74,2 \%$ na análise sem os categóricos), conforme resultados do português brasileiro como um todo.

O tipo de referência não foi selecionado estatisticamente pelo programa, mas, no nível em que poderia ter sido selecionado, na análise com todos os colaboradores, o nível de significância é de 0,122 , com pouca probabilidade de seleção. Na análise sem os categóricos, o nível de significância é de 0,325, ou seja, com probabilidade ainda menor, quase remota, de seleção. Os pesos relativos, de qualquer forma, favoreceriam a referência genérica para o pronome a gente.

Em suma, percebe-se que a comunidade de Aceguá não compartilha apenas cultura, gastronomia, tradição, gostos, música, laços familiares etc, mas também 
compartilha padrões linguísticos, exceto no tipo de referência, e sociais comuns, ainda que a distribuição geral dos dados seja de maior uso de a gente entre brasileiros e maior uso de nós entre uruguaios.

\subsection{Análise dos resultados apenas dos brasileiros}

Nessa seção, fizemos uma análise apenas com os brasileiros de Aceguá, a fim de identificar se os padrões brasileiros são semelhantes aos padrões uruguaios, e se as variedades, consequentemente, dialogam entre si com o fenômeno da alternância entre nós e a gente. Nesse rearranjo do Quadro 9, excluindo os uruguaios, temos a seguinte configuração social:

Quadro 9: Distribuição dos colaboradores brasileiros

\begin{tabular}{|c|c|}
\hline Faixa etária & Brasileiros \\
\hline 15 a 29 anos & 4 homens \\
& 3 mulheres \\
\hline 31 a 49 anos & 2 homens \\
& 5 mulheres \\
\hline Acima de 50 anos & 3 homens \\
& 2 mulheres \\
\hline Total & 19 colaboradores \\
\hline
\end{tabular}

Em termos de distribuição dos dados, os resultados de a gente chegam a 58,6\% enquanto os de nós ficam com 41,4\% na análise com todos os colaboradores brasileiros. Retirando os categóricos, a frequência do pronome a gente aumenta ainda mais para $63,4 \%$ versus $36,6 \%$ para o pronome nós conforme a Tabela 10 seguinte.

Tabela 10: Percentagem global das variantes nós e a gente na posição de sujeito do português brasileiro da amostra de Aceguá

\begin{tabular}{l|l|l}
\hline & \multicolumn{2}{|c}{ Colaboradores } \\
\hline Variantes & Com todos & Sem os categóricos de nós \\
\hline A GENTE & $317 / 541=58,6 \%$ & $317 / 500=63,4 \%$ \\
\hline NÓS & $224 / 541=41,4 \%$ & $183 / 500=36,6 \%$ \\
\hline
\end{tabular}

Com a análise dos dados de brasileiros, comprova-se que o pronome a gente é mais produtivo no português brasileiro de Aceguá do que no português uruguaio de Aceguá. No português uruguaio, essa frequência chega 49,1\%, e no português brasileiro 
é de 63,4\%, ambas em análises sem os casos categóricos, o que aumenta, consequentemente, a frequência de a gente. Logo, as amostras têm diferenças de distribuição global das duas variantes em jogo, mas em termos estatísticos de variáveis linguísticas e sociais, as semelhanças aumentam.

Essa análise, da mesma forma que as outras análises, apenas selecionou a faixa etária como estatisticamente significativa. O sexo não foi selecionado em nenhuma análise.

As variáveis sociais retiradas foram as mesmas das outras análises, ou seja, a escolaridade e a nacionalidade (porque o objetivo agora é só a fala de brasileiros). Deve-se levar em conta que todos os uruguaios entrevistados têm ensino médio, por isso essa variável foi retirada das análises.

Já as variáveis linguísticas, todas foram selecionadas: preenchimento do sujeito, paralelismo linguístico e tempo verbal/saliência fônica e tipo de referência. Para essa análise, foram considerados apenas os dados de sujeito para manter os efeitos de comparabilidade com todas as análises e porque também não estava dando convergência.

Posto isso, analisamos as variáveis sociais e linguísticas que condicionam o fenômeno variável de primeira pessoa do plural no português brasileiro.

\subsubsection{Variáveis sociais}

A variável social selecionada na análise de brasileiros foi a faixa etária, com os jovens $(0,77$ e 0,76$)$ favorecendo o uso de a gente como primeira pessoa do plural, respectivamente, na análise com todos os colaboradores e na análise sem os casos categóricos. Esse padrão de mudança linguística direcionada pelos jovens é o mesmo da análise uruguaia sem os casos categóricos e da análise geral com brasileiros e uruguaios. Na Tabela 11 a seguir, podemos ver os resultados das variáveis sociais para a análise de brasileiros. 
Tabela 11: Efeito das variáveis sociais em relação ao uso do pronome a gente no português brasileiro da amostra de Aceguá

\begin{tabular}{|c|c|c|c|c|c|c|}
\hline & \multicolumn{6}{|c|}{ Colaboradores } \\
\hline & \multicolumn{3}{|c|}{ Com todos } & \multicolumn{3}{|c|}{ Sem os categóricos de nós } \\
\hline Variáveis sociais & $\begin{array}{c}\mathbf{N} \text { de dados/ } \\
\text { Total }\end{array}$ & $\begin{array}{c}\text { Percen- } \\
\text { tagem }\end{array}$ & Peso & $\begin{array}{c}\text { N de dados/ } \\
\text { Total }\end{array}$ & $\begin{array}{c}\text { Percen- } \\
\text { tagem }\end{array}$ & Peso \\
\hline \multicolumn{7}{|l|}{ Faixa etária } \\
\hline 15 a 30 anos & $113 / 137$ & $82,5 \%$ & 0,77 & $113 / 135$ & $83,7 \%$ & 0,76 \\
\hline 31 a 49 anos & $139 / 258$ & $53,9 \%$ & 0,42 & $139 / 224$ & $62,1 \%$ & 0,44 \\
\hline Acima de 50 anos & $65 / 146$ & $44,5 \%$ & 0,35 & $65 / 141$ & $46,1 \%$ & 0,31 \\
\hline \multicolumn{7}{|l|}{ Sexo } \\
\hline Mulher & $177 / 268$ & $66 \%$ & {$[0,54]$} & $177 / 268$ & $66 \%$ & {$[0,48]$} \\
\hline Homem & $140 / 273$ & $51,3 \%$ & {$[0,45]$} & $140 / 232$ & $60,3 \%$ & {$[0,51]$} \\
\hline Total & $317 / 541$ & $58,6 \%$ & & $317 / 500$ & $63,4 \%$ & \\
\hline Input & & & 0,62 & & & 0,68 \\
\hline
\end{tabular}

Assim como a análise geral de uruguaios e brasileiros e a análise de apenas uruguaios, a análise brasileira também selecionou a faixa etária como estatisticamente significativa com o mesmo padrão etário de mudança linguística, em que os jovens $(0,77$ e 0,76$)$ favorecem a variante mais inovadora (a gente). Tanto na análise com todos os colaboradores quanto na análise sem os casos categóricos, os pesos relativos são semelhantes, até porque houve poucos colaboradores categóricos no uso de nós, o que não afetou o resultado final.

A variável sexo novamente não foi selecionada na análise brasileira. No último nível de provável seleção (nível 5), antes da melhor análise step-up, com todos os colaboradores, o nível de significância é de 0,082, ou seja, com uma probabilidade alta de ser selecionado, mostrando que as mulheres $(0,54)$ favorecem o pronome a gente. Já na análise sem os casos categóricos, o nível de significância é de 0,670, com raríssima probabilidade de seleção, conforme Tabela 12. 
Tabela 12: Peso relativo da variável "sexo" em cada nível de significância do português brasileiro de Aceguá.

\begin{tabular}{|c|c|c|c|c|c|c|}
\hline & \multicolumn{6}{|c|}{ Colaboradores } \\
\hline & \multicolumn{3}{|c|}{ Com todos } & \multicolumn{3}{|c|}{ Sem os categóricos de nós } \\
\hline Níveis de significância & Mulher & Homem & $\begin{array}{l}\text { Signifi- } \\
\text { cância }\end{array}$ & Mulher & Homem & $\begin{array}{l}\text { Signifi- } \\
\text { cância }\end{array}$ \\
\hline Nível 0 & & & $\begin{array}{l}0,586 \\
\text { Input }\end{array}$ & & & $\begin{array}{l}0,634 \\
\text { Input }\end{array}$ \\
\hline Nível $1-$ Sexo & {$[0,57]$} & {$[0,42]$} & 0,000 & {$[0,52]$} & {$[0,46]$} & 0,191 \\
\hline $\begin{array}{l}\text { Níve } 2-\text { Sexo, } \\
\text { paralelismo }\end{array}$ & {$[0,56]$} & {$[0,43]$} & 0,007 & {$[0,51]$} & {$[0,48]$} & 0,712 \\
\hline $\begin{array}{l}\text { Nível } 3 \text { - Sexo, faixa } \\
\text { etária e paralelismo }\end{array}$ & {$[0,56]$} & {$[0,43]$} & 0,014 & {$[0,50]$} & {$[0,49]$} & 0,815 \\
\hline $\begin{array}{l}\text { Nível } 4-\text { Sexo, faixa } \\
\text { etária, tempo verbal e } \\
\text { paralelismo }\end{array}$ & {$[0,56]$} & {$[0,43]$} & 0,021 & {$[0,50]$} & {$[0,50]$} & 0,983 \\
\hline $\begin{array}{l}\text { Nível } 5 \text { - Sexo, faixa } \\
\text { etária, preenchimento do } \\
\text { sujeito, tempo verbal e } \\
\text { paralelismo }\end{array}$ & {$[0,55]$} & {$[0,45]$} & 0,082 & {$[0,49]$} & {$[0,51]$} & 0,728 \\
\hline $\begin{array}{l}\text { Nível } 6 \text { - Sexo, faixa } \\
\text { etária, preenchimento do } \\
\text { sujeito, tipo de } \\
\text { referência, tempo verbal, } \\
\text { paralelismo }\end{array}$ & {$[0,54]$} & {$[0,45]$} & 0,089 & {$[0,48]$} & {$[0,51]$} & 0,670 \\
\hline
\end{tabular}

O programa escolhe o grupo mais significativo e procura adicionar um segundo grupo que aumente sua probabilidade estatística. O conjunto de grupos assim incorporados no modelo é chamado de solução step-up (SANKOFF, 1988a). Segundo Guy e Zilles (2007, p. 164-165),

o processo do step-up é o seguinte: o programa começa fazendo uma análise em que se calcula só um valor de input e nenhum peso de fator. Para esse 'nível zero', calcula-se um logaritmo de verossimilhança. Aí, o programa passa a fazer, no chamado 'nível um', rodadas em que são usados o valor do input e um só grupo de fatores de cada vez. O programa faz uma rodada desse tipo para cada grupo de fatores existente no arquivo que está sendo analisado [...] de todas essas rodadas, escolhe-se o melhor grupo de fatores, em termos de significância [...] E o processo continua assim, escolhendo, em cada nível, o mais significativo dos grupos de fatores restantes

Para Tagliamonte (2006, p. 140), "as repetições ou "iterações" mostram o progresso do programa na procura do cálculo de "máxima probabilidade" a respeito dos

\footnotetext{
${ }^{92}$ O nível 2, para a análise brasileira sem os casos categóricos, já começa com a faixa etária. O restante dos níveis é igual.
} 
pesos dos fatores com um determinado grau de precisão, no ponto em que é indicada a "convergência" (Rand and Sankoff, 1990)"93.

Para manter a comparabilidade dos resultados e também verificar se há mudanças na análise brasileira com e sem categóricos, analisamos o comportamento individual dos colaboradores. No caso dessa análise brasileira, não houve mudanças significativas na análise com todos os colaboradores e na análise sem os categóricos. A distribuição dos colaboradores passa a ser a do Quadro 10.

Quadro 10: Distribuição dos colaboradores brasileiros entre a fala categórica em nós e a fala variável

\begin{tabular}{|c|c|c|c|c|c|}
\hline \multirow{2}{*}{ Faixa etária } & \multicolumn{2}{|c|}{ Fala categórica em nós } & \multicolumn{2}{c|}{ Fala variável } & \multirow{2}{*}{ Total geral } \\
\cline { 2 - 5 } & Mulher & Homem & Mulher & Homem & \\
\hline 15 a 30 anos & ----- & 1 & 3 & 3 & 7 \\
\hline 31 a 49 anos & ----- & 1 & 5 & 1 & 7 \\
\hline $\begin{array}{c}\text { Acima de 50 } \\
\text { anos }\end{array}$ & ----- & 1 & 2 & 2 & 5 \\
\hline Total & & 3 & 10 & 6 & 19 \\
\hline
\end{tabular}

Com relação à identificação dos colaboradores, das 19 entrevistas brasileiras, apenas 3 colaboradores (um de cada faixa etária) usam categoricamente o nós, e 2 colaboradores jovens usam $100 \%$ a gente como pronome de primeira pessoa do plural. É importante também observar a quantidade pequena de dados desses colaboradores, uma vez que a mulher jovem tem 11 dados de a gente, os dois homens jovens tem 8 dados de a gente e 2 dados de nós, respectivamente, o homem adulto tem 35 dados de nós e o homem acima de 50 tem apenas 5 dados de nós. Esse adulto com 35 dados, por exemplo, é casado com uma uruguaia que pouco fala português. De qualquer forma, essa distribuição desequilibrada também pode interferir nos resultados conforme a Tabela 13.

\footnotetext{
${ }^{93}$ The 'iterations' show you 'na account of the program's progress in finding the "maximum likelihood" estimation of the factor weights to a certain degree of accuracy, at which point "convergence" is indicated' (Rand and Sankoff 1990) (TAGLIAMONTE, 2006, p. 141).
} 
Tabela 13: Percentagem de uso do pronome a gente na fala dos colaboradores brasileiros

\begin{tabular}{|c|c|c|}
\hline Identificação dos colaboradores brasileiros & $\begin{array}{l}\text { Número de } \\
\text { dados/Total }\end{array}$ & Frequência \\
\hline JOS, de 15 a 30 anos, ensino médio & $7 / 7$ & $100 \%$ \\
\hline NAI, de 15 a 30 anos, ensino fundamental & $11 / 11$ & $100 \%$ \\
\hline BOL, de 15 a 30 anos, ensino médio & $43 / 45$ & $95,6 \%$ \\
\hline MAI, de 15 a 30 anos, ensino médio & $36 / 39$ & $92,3 \%$ \\
\hline EDU, de 15 a 30 anos, ensino médio & $11 / 13$ & $84,6 \%$ \\
\hline FLA, de 31 a 49 anos, ensino superior & $25 / 31$ & $80,6 \%$ \\
\hline ROB, de 31 a 49 anos, ensino médio & $9 / 12$ & $75 \%$ \\
\hline CAR, de 31 a 49 anos, ensino superior & $27 / 43$ & $62,8 \%$ \\
\hline MAL, de 31 a 49 anos, ensino superior & $32 / 53$ & $60,4 \%$ \\
\hline MAC, de 31 a 49 anos, ensino superior & $12 / 20$ & $60 \%$ \\
\hline MAR, acima de 50 anos, ensino médio & $10 / 18$ & $55,6 \%$ \\
\hline EDI, de 31 a 49 anos, ensino superior & $34 / 65$ & $52,3 \%$ \\
\hline HIL, acima de 50 anos, ensino médio & $10 / 21$ & $47,6 \%$ \\
\hline MAN, acima de 50 anos, ensino fundamental & $27 / 60$ & $45 \%$ \\
\hline PIU, acima de 50 anos, ensino fundamental & $18 / 42$ & $42,9 \%$ \\
\hline LIS, de 15 a 30 anos, ensino médio & $5 / 20$ & $25 \%$ \\
\hline GUI, de 15 a 30 anos, ensino médio & $0 / 2$ & $0 \%$ \\
\hline PAI, acima de 50 anos, ensino médio & $0 / 5$ & $0 \%$ \\
\hline LEO, de 31 a 49 anos, ensino médio & $0 / 34$ & $0 \%$ \\
\hline TOTAL $^{94}$ & $317 / 541$ & $58,6 \%$ \\
\hline
\end{tabular}

Por conta dos casos categóricos em nós e dos poucos dados, fizemos outra análise retirando GUI, PAI e LEO. Na análise uruguaia, são 9 colaboradores, metade jovens, que usam categoricamente nós pelos motivos de menos mobilidade social e menos interação com o Brasil e com o português brasileiro, como já foi explicado. Os três brasileiros (JOS, NAI e BOL) que utilizam a gente acima de $95 \%$ também haviam sido retirados da análise, mas, como não houve diferenças significativas, esses dados foram mantidos.

De uma forma geral, os falantes brasileiros e uruguaios mantêm certa coerência social e linguística quanto à variação pronominal de primeira pessoa do plural, ainda que a distribuição dos dados seja diferente. Também constata-se que a variante $a$ gente está mais expandida no português brasileiro do que no português uruguaio por ser mais antiga no Brasil como um todo. Os condicionantes linguísticos serão analisados adiante.

\footnotetext{
${ }^{94}$ Total com base nos resultados da análise brasileira
} 


\subsubsection{Variáveis linguísticas}

Todas as variáveis linguísticas foram selecionadas e os resultados linguísticos foram semelhantes às outras três análises variacionistas, tanto em termos de seleção de variável quanto em termos de significância dos fatores. Nessa análise, o padrão linguístico do português brasileiro que favorece o pronome a gente é: sujeito explícito (0,57 e 0,56); paralelismo linguístico, na medida em que dados de a gente são mais produtivos quando são precedidos também de a gente, seja implícito $(0,91$ e 0,89$)$ ou explícito $(0,82$ e 0,77$)$; os tempos verbais presente com neutralização $(0,69$ e 0,70$)$ e infinitivo/gerúndio $\left(0,63\right.$ e $\left.0,57^{95}\right)$; e a referência genérica. Vejamos todos os resultados na Tabela 14.

\footnotetext{
$95 \mathrm{O}$ primeiro peso relativo de cada parêntese é referente à análise com todos os colaboradores e o
} segundo peso relativo de cada parêntese é referente à análise sem os casos categóricos. 
Tabela 14: Efeito das variáveis linguísticas em relação ao pronome a gente no português brasileiro da amostra de Aceguá

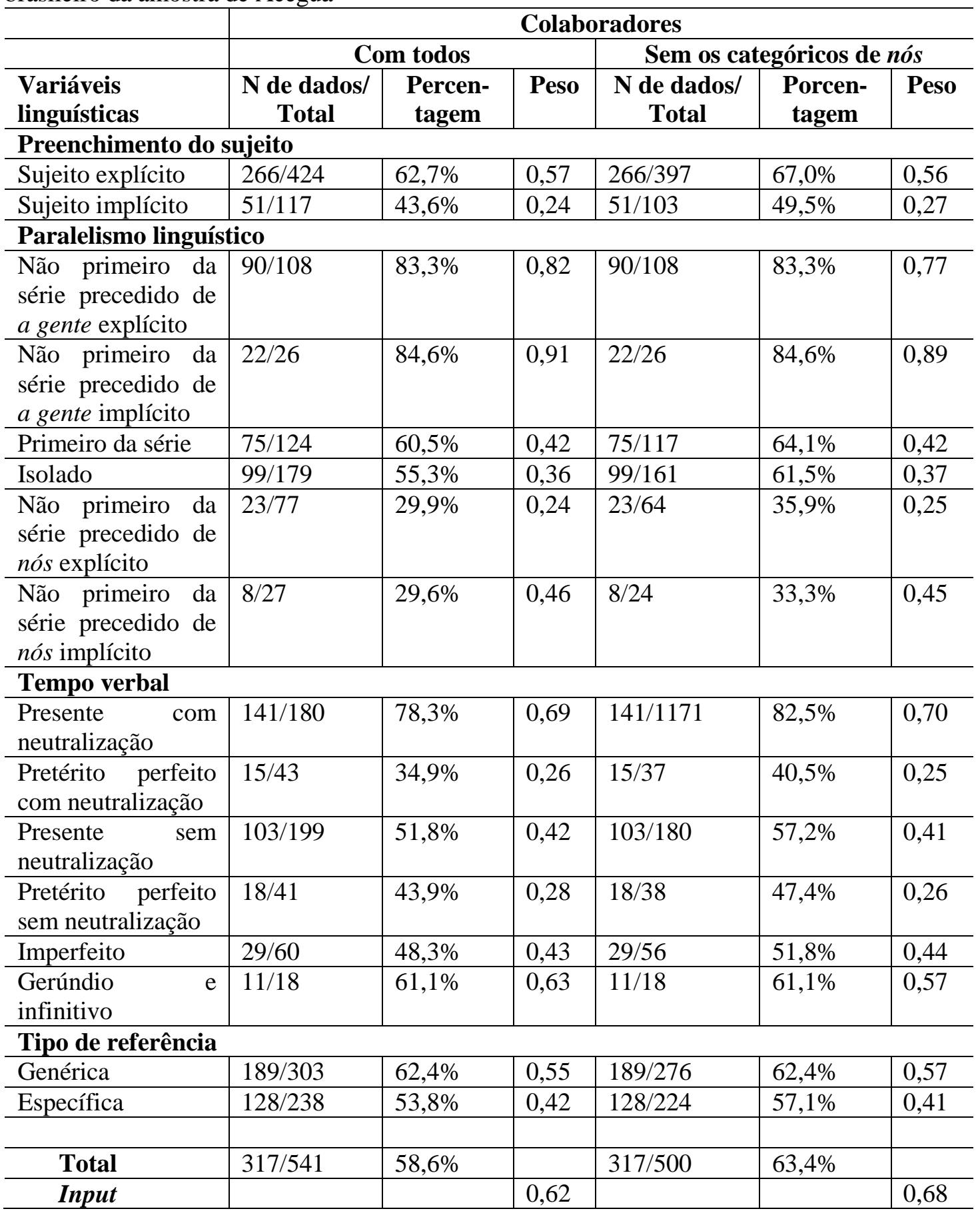

Na próxima seção, haverá uma comparação linguística e social entre as três análises feitas pelo programa estatístico com: (i) monolíngues e bilíngues juntos; (ii) apenas bilíngues uruguaios; e (iii) apenas monolíngues brasileiros. 


\subsection{Análise comparativa das três rodadas}

Para recapitular as três análises realizadas, optamos por resumir os resultados na Tabela 15 com a frequência geral acerca da alternância entre nós e a gente; no Quadro 11 com as variáveis selecionadas, por ordem de significância, em cada análise; na tabela 16 com as três análises com todos os colaboradores, na tabela 17 com as três análises sem os casos categóricos; e na tabela 18 com a comparação de peso relativo das três análises com todos os colaboradores e sem os casos categóricos ao mesmo tempo.

Tabela 15: Percentagem global das variantes nós e a gente nas três análises

\begin{tabular}{l|c|c|c|c}
\hline & \multicolumn{4}{c}{ Colaboradores } \\
\hline & \multicolumn{3}{|c}{ Com todos } & Sem os categóricos de nós \\
\hline Colaboradores & A GENTE & NÓS & A GENTE & NÓS \\
\hline Brasileiros & $45,1 \%$ & $54,9 \%$ & $58,3 \%$ & $41,7 \%$ \\
uruguaios & $452 / 1002$ & $550 / 1002$ & $452 / 775$ & $323 / 775$ \\
\hline Uruguaios & $29,3 \%$ & $70,7 \%$ & $49,1 \%$ & $50,9 \%$ \\
& $135 / 461$ & $326 / 461$ & $135 / 275$ & $140 / 275$ \\
\hline Brasileiros & $58,6 \%$ & $41,4 \%$ & $63,4 \%$ & $36,6 \%$ \\
& $317 / 541$ & $224 / 541$ & $317 / 500$ & $183 / 500$ \\
\hline
\end{tabular}

Na Tabela 15, verifica-se que o pronome a gente ocorre em todas as análises, só que é mais frequente sem os casos categóricos de nós na fala dos brasileiros $(63,4 \%)$, confirmando a hipótese que $a$ gente seria uma variante inovadora e recente no português uruguaio $(49,1 \%)$. No entanto, a grande diferença é entre a análise com dados dos uruguaios com todos os colaboradores $(29,3 \%)$ e sem os casos categóricos $(49,1 \%)$, o que mostra que o pronome a gente está até bem avançado nessa variedade linguística.

Para efeitos de comparação, o Quadro 11 a seguir ilustra como as variáveis linguísticas e sociais estão distribuídas nas três análises, a saber, na análise conjunta de brasileiros e uruguaios; na análise apenas com uruguaios; e na análise apenas com brasileiros. A intenção é obtermos um quadro sintético e paralelo de todas as análises estatísticas. 
Quadro 11: Ordem de significância das variáveis sociais e linguísticas nas três análises

\begin{tabular}{|c|c|c|c|c|c|c|}
\hline & \multicolumn{6}{|c|}{ Colaboradores } \\
\hline & \multicolumn{3}{|c|}{ Com todos } & \multicolumn{3}{|c|}{ Sem os categóricos } \\
\hline VARIÁVEIS & PB e PU & PU & PB & PB e PU & PU & PB \\
\hline $\begin{array}{l}\text { Paralelismo } \\
\text { linguístico }\end{array}$ & $1^{\circ}$ & $1^{\circ}$ & $1^{\circ}$ & $1^{\circ}$ & $1^{\circ}$ & $2^{\circ}$ \\
\hline $\begin{array}{l}\text { Preenchimen- } \\
\text { to do sujeito }\end{array}$ & $2^{\circ}$ & $2^{\circ}$ & $4^{\circ}$ & $3^{\circ}$ & $2^{\circ}$ & $4^{\circ}$ \\
\hline $\begin{array}{l}\text { Tempo/ } \\
\text { Saliência }\end{array}$ & $4^{\circ}$ & $3^{\circ}$ & $3^{\circ}$ & $2^{\circ}$ & $3^{\circ}$ & $3^{\circ}$ \\
\hline $\begin{array}{l}\text { Tipo de } \\
\text { referência }\end{array}$ & $\begin{array}{l}\text { Variável não } \\
\text { selecionada }\end{array}$ & $\begin{array}{l}\text { Variável não } \\
\text { selecionada }\end{array}$ & $5^{\circ}$ & $5^{\circ}$ & $\begin{array}{l}\text { Variável não } \\
\text { selecionada }\end{array}$ & $5^{\circ}$ \\
\hline Faixa etária & $5^{\circ}$ & $4^{\circ}$ & $2^{\circ}$ & $4^{\circ}$ & $4^{\circ}$ & $1^{\circ}$ \\
\hline $\begin{array}{l}\text { Naciona- } \\
\text { Lidade }\end{array}$ & $3^{\circ}$ & $\begin{array}{c}\text { Não se } \\
\text { aplica }\end{array}$ & $\begin{array}{l}\text { Não se } \\
\text { aplica }\end{array}$ & $\begin{array}{l}\text { Variável não } \\
\text { selecionada }\end{array}$ & $\begin{array}{c}\text { Não se } \\
\text { aplica }\end{array}$ & Não se aplica \\
\hline Sexo & $\begin{array}{l}\text { Variável não } \\
\text { selecionada }\end{array}$ & $\begin{array}{l}\text { Variável não } \\
\text { selecionada }\end{array}$ & $\begin{array}{l}\text { Variável não } \\
\text { selecionada }\end{array}$ & $\begin{array}{l}\text { Variável não } \\
\text { selecionada }\end{array}$ & $\begin{array}{l}\text { Variável não } \\
\text { selecionada }\end{array}$ & $\begin{array}{l}\text { Variável não } \\
\text { selecionada }\end{array}$ \\
\hline $\begin{array}{l}\text { Nível de } \\
\text { significância }\end{array}$ & 0,007 & 0,019 & 0,000 & 0,028 & 0,004 & 0,010 \\
\hline Input & 0,42 & 0,18 & 0,62 & 0,62 & 0,50 & 0,68 \\
\hline
\end{tabular}

Analisando as análises sem os casos categóricos, verifica-se que na análise global da comunidade, temos: paralelismo linguístico, tempo/saliência, preenchimento do sujeito, faixa etária e tipo de referência. Na análise com os uruguaios, temos: paralelismo linguístico, preenchimento do sujeito, tempo/saliência e faixa etária. $\mathrm{Na}$ análise com os brasileiros, temos: faixa etária, paralelismo linguístico, tempo/saliência, preenchimento do sujeito e tipo de referência. A maior diferença da análise sem os categóricos é que na análise brasileira o tipo de referência é estatisticamente significativo e a faixa etária é a primeira variável hierarquicamente importante, sendo que na análise uruguaia está em quarto lugar.

Os resultados do input (média corrigida) apontam também para o fato de o português brasileiro $(0,62$ e 0,68$)$ estar mais avançado do que o português uruguaio $(0,18$ e 0,50$)$ no uso de a gente. O input é a média geral ou global de aplicação da regra que serve de base para o peso relativo. Ainda assim, é possível perceber o salto no input do português uruguaio da fronteira quando aumenta de 0,18 (com todos os colaboradores uruguaios) para 0,50 (sem os colaboradores uruguaios categóricos), chegando perto da probabilidade brasileira da fronteira. Na Tabela 16, é possível comparar as três análises com todos os colaboradores. 
Tabela 16: Comparação das variáveis sociais e linguísticas nas três análises (com todos os dados)

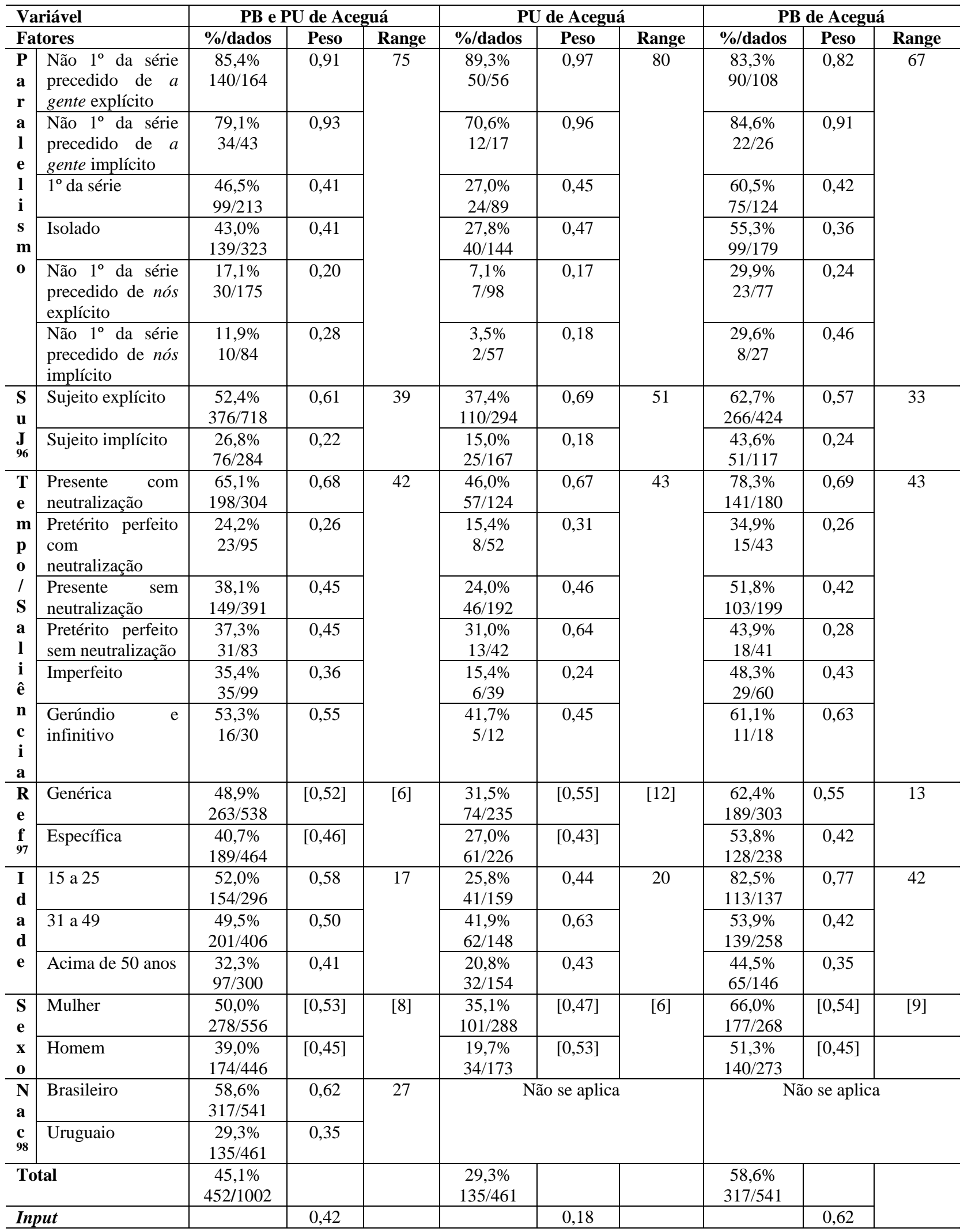

\footnotetext{
${ }^{96} \mathrm{Suj}=$ sujeito.

${ }^{97}$ Ref = tipo de referência .

${ }^{98} \mathrm{Nac}=$ nacionalidade.
} 
Nos resultados de todas as análises com todos os colaboradores, as maiores diferenças concentram-se na faixa etária, no tempo verbal e no tipo de referência. A faixa etária dos brasileiros mantem o padrão de mudança linguística via jovens, mas a análise uruguaia mostra os adultos favorecendo a gente. Sobre esse padrão da faixa etária dos adultos uruguaios, de acordo com Mollica et alii (2008), os falantes adultos, em geral, tendem a oscilar sua frequência de uso - ora se aproximando dos jovens, ora dos colaboradores de mais idade - motivados, costumeiramente, por razões extralinguísticas, como a inserção no mercado de trabalho. É justamente essa a diferença que vemos na análise sem os casos categóricos, justamente porque os dados categóricos de nós são de falantes que têm menos mobilidade social e estão inseridos no mercado de trabalho do Uruguai, sem muito contato com o Brasil.

No tempo verbal/saliência, o presente com neutralização favorece a gente na análise brasileira e uruguaia. O gerúndio/infinitivo e pretérito perfeito sem neutralização se invertem nessas duas análises, no sentido de que no português uruguaio os tempos nominais $(0,45)$ desfavorecem a gente e o pretérito perfeito sem neutralização favorece a gente $(0,64)$. No português brasileiro da fronteira, é o contrário, ou seja, os tempos nominais $(0,63)$ favorecem a gente e o pretérito perfeito sem neutralização desfavorece bruscamente $(0,28)$. Além disso, a referência só é selecionada na análise brasileira, sendo o genérico o tipo mais favorecedor para o pronome a gente.

Em termos de range, temos 80 e 67 para o paralelismo, 51 e 33 para o preenchimento do sujeito, 43 e 43 para o tempo verbal, [12] e 13 para a referência, 20 e 42 para a idade, e [6] e [9] para o sexo. Os primeiros valores de cada par são do PU e os segundos valores do PB. Assim, a maior diferença de range entre as análises é mesmo a faixa etária. As variáveis linguísticas são semelhantes, principalmente o tempo verbal, com valores idênticos, e a referência, caso tivesse sido selecionada no PU, ou seja, as gramáticas variáveis de ambos os dialetos coincidem.

A seguir, na Tabela 17, comparam-se todas as análises, mas sem os dados categóricos de nós. 
Tabela 17: Comparação das variáveis sociais e linguísticas nas três análises (sem os dados categóricos de nós)

\begin{tabular}{|c|c|c|c|c|c|c|c|c|c|c|}
\hline \multirow{2}{*}{\multicolumn{2}{|c|}{$\begin{array}{l}\text { Variável } \\
\text { Fatores }\end{array}$}} & \multicolumn{3}{|c|}{ PB e PU de Aceguá } & \multicolumn{3}{|c|}{ PU de Aceguá } & \multicolumn{3}{|c|}{ PB de Aceguá } \\
\hline & & $\% /$ dados & Peso & Range & \%/dados & Peso & Range & \%/dados & Peso & Range \\
\hline \multirow{6}{*}{$\begin{array}{l}\mathbf{P} \\
\mathbf{a} \\
\mathbf{r} \\
\mathbf{a} \\
\mathbf{l} \\
\mathbf{e} \\
\mathbf{l} \\
\mathbf{i} \\
\mathbf{s} \\
\mathbf{m} \\
\mathbf{o}\end{array}$} & $\begin{array}{l}\text { Não } 1^{\circ} \text { da série } \\
\text { precedido de } a \\
\text { gente explícito }\end{array}$ & $\begin{array}{c}85,4 \% \\
140 / 164\end{array}$ & 0,84 & \multirow[t]{6}{*}{65} & $\begin{array}{c}89,3 \% \\
50 / 56\end{array}$ & 0,93 & \multirow[t]{6}{*}{92,9} & $\begin{array}{l}83,3 \% \\
90 / 108\end{array}$ & 0,77 & \multirow[t]{6}{*}{64} \\
\hline & $\begin{array}{l}\text { Não } 1^{\circ} \text { da série } \\
\text { precedido de } a \\
\text { gente implícito }\end{array}$ & $\begin{array}{l}79,1 \% \\
34 / 43\end{array}$ & 0,88 & & $\begin{array}{l}70,6 \% \\
12 / 17\end{array}$ & 0,88 & & $\begin{array}{l}84,6 \% \\
22 / 26\end{array}$ & 0,89 & \\
\hline & $1^{\circ}$ da série & $\begin{array}{c}58,9 \% \\
99 / 168\end{array}$ & 0,39 & & $\begin{array}{c}47,1 \% \\
24 / 51\end{array}$ & 0,34 & & $\begin{array}{l}64,1 \% \\
75 / 117\end{array}$ & 0,42 & \\
\hline & Isolado & $\begin{array}{c}56 \% \\
139 / 248\end{array}$ & 0,38 & & $\begin{array}{c}46,0 \% \\
40 / 87\end{array}$ & 0,44 & & $\begin{array}{l}61,5 \% \\
99 / 161\end{array}$ & 0,37 & \\
\hline & $\begin{array}{l}\text { Não } 1^{\circ} \text { da série } \\
\text { precedido de nós } \\
\text { explícito }\end{array}$ & $\begin{array}{l}29,1 \% \\
30 / 103\end{array}$ & 0,23 & & $\begin{array}{c}17,9 \% \\
7 / 39\end{array}$ & 0,14 & & $\begin{array}{l}35,9 \% \\
23 / 64\end{array}$ & 0,25 & \\
\hline & $\begin{array}{l}\text { Não } 1^{\circ} \text { da série } \\
\text { precedido de nós } \\
\text { implícito }\end{array}$ & $\begin{array}{c}20,4 \% \\
10 / 49\end{array}$ & 0,27 & & $\begin{array}{l}8,0 \% \\
2 / 25\end{array}$ & 0,07 & & $\begin{array}{c}33,3 \% \\
8 / 24\end{array}$ & 0,45 & \\
\hline $\begin{array}{l}\mathbf{S} \\
\mathbf{u}\end{array}$ & Sujeito explícito & $\begin{array}{c}64,4 \% \\
376 / 584\end{array}$ & 0,59 & \multirow[t]{2}{*}{36} & $\begin{array}{c}58,8 \% \\
110 / 187\end{array}$ & 0,67 & \multirow[t]{2}{*}{50} & $\begin{array}{c}67,0 \% \\
266 / 397\end{array}$ & 0,56 & \multirow[t]{2}{*}{29} \\
\hline $\mathbf{j}$ & Sujeito implícito & $\begin{array}{l}39,8 \% \\
76 / 191\end{array}$ & 0,23 & & $\begin{array}{c}28,4 \% \\
25 / 88\end{array}$ & 0,17 & & $\begin{array}{l}49,5 \% \\
51 / 103\end{array}$ & 0,27 & \\
\hline \multirow{3}{*}{$\begin{array}{l}\text { T } \\
\text { e } \\
\text { m } \\
\text { p } \\
\text { o } \\
/ \\
\text { S }\end{array}$} & $\begin{array}{l}\text { Presente com } \\
\text { neutralizacão }\end{array}$ & $\begin{array}{c}82,8 \% \\
198 / 239\end{array}$ & 0,74 & \multirow[t]{6}{*}{51} & $\begin{array}{c}83,8 \% \\
57 / 68\end{array}$ & 0,83 & \multirow[t]{6}{*}{71} & $\begin{array}{c}78,3 \% \\
141 / 180\end{array}$ & 0,69 & \multirow[t]{6}{*}{43} \\
\hline & $\begin{array}{l}\text { Pretérito perfeito } \\
\text { com } \\
\text { neutralização }\end{array}$ & $\begin{array}{c}33,8 \% \\
23 / 68\end{array}$ & 0,23 & & $\begin{array}{c}25,8 \% \\
8 / 31\end{array}$ & 0,18 & & $\begin{array}{c}34,9 \% \\
15 / 43\end{array}$ & 0,26 & \\
\hline & $\begin{array}{l}\text { Presente sem } \\
\text { neutralização }\end{array}$ & $\begin{array}{c}49,8 \% \\
149 / 299\end{array}$ & 0,41 & & $\begin{array}{l}38,7 \% \\
46 / 119\end{array}$ & 0,42 & & $\begin{array}{c}51,8 \% \\
103 / 199\end{array}$ & 0,42 & \\
\hline \multirow{3}{*}{$\begin{array}{l}\mathbf{a} \\
\mathbf{l} \\
\mathbf{i} \\
\hat{\mathbf{e}} \\
\mathbf{n} \\
\mathbf{c} \\
\mathbf{i} \\
\mathbf{a}\end{array}$} & $\begin{array}{l}\text { Pretérito perfeito } \\
\text { sem neutralização }\end{array}$ & $\begin{array}{l}49,2 \% \\
31 / 63\end{array}$ & 0,41 & & $\begin{array}{c}52,0 \% \\
13 / 25\end{array}$ & 0,68 & & $\begin{array}{c}43,9 \% \\
18 / 41\end{array}$ & 0,28 & \\
\hline & Imperfeito & $\begin{array}{l}43,8 \% \\
35 / 80\end{array}$ & 0,36 & & $\begin{array}{c}25,0 \% \\
6 / 24\end{array}$ & 0,12 & & $\begin{array}{l}48,3 \% \\
29 / 60\end{array}$ & 0,43 & \\
\hline & $\begin{array}{l}\text { Gerúndio } \\
\text { infinitivo }\end{array}$ & $\begin{array}{l}61,5 \% \\
16 / 26\end{array}$ & 0,56 & & $\begin{array}{c}62,5 \% \\
5 / 8\end{array}$ & 0,46 & & $\begin{array}{c}61,1 \% \\
11 / 18\end{array}$ & 0,63 & \\
\hline \multirow{2}{*}{$\begin{array}{l}\text { R } \\
\text { e } \\
\text { f }\end{array}$} & Genérica & $\begin{array}{c}61,6 \% \\
263 / 427\end{array}$ & 0,55 & \multirow[t]{2}{*}{12} & $\begin{array}{l}49,0 \% \\
74 / 151\end{array}$ & {$[0,54]$} & \multirow[t]{2}{*}{ [10] } & $\begin{array}{c}68,5 \% \\
189 / 276\end{array}$ & 0,57 & \multirow[t]{2}{*}{16} \\
\hline & Específica & $\begin{array}{c}54,3 \% \\
189 / 348\end{array}$ & 0,43 & & $\begin{array}{l}49,2 \% \\
61 / 124\end{array}$ & {$[0,44]$} & & $\begin{array}{c}57,1 \% \\
128 / 224\end{array}$ & 0,41 & \\
\hline \multirow{3}{*}{$\begin{array}{l}\text { I } \\
\text { d } \\
\text { a } \\
\text { d } \\
\text { e }\end{array}$} & 15 a 25 & $\begin{array}{c}82,4 \% \\
154 / 187\end{array}$ & 0,74 & \multirow[t]{3}{*}{39} & $\begin{array}{l}78,8 \% \\
41 / 52\end{array}$ & 0,81 & \multirow[t]{3}{*}{41} & $\begin{array}{c}83,7 \% \\
113 / 135\end{array}$ & 0,76 & \multirow[t]{3}{*}{45} \\
\hline & 31 a 49 & $\begin{array}{c}57,3 \% \\
201 / 351\end{array}$ & 0,45 & & $\begin{array}{l}48,8 \% \\
62 / 127\end{array}$ & 0,42 & & $\begin{array}{c}62,1 \% \\
139 / 224\end{array}$ & 0,44 & \\
\hline & Acima de 50 anos & $\begin{array}{l}40,9 \% \\
97 / 237\end{array}$ & 0,35 & & $\begin{array}{l}33,3 \% \\
32 / 96\end{array}$ & 0,40 & & $\begin{array}{l}46,1 \% \\
65 / 141\end{array}$ & 0,31 & \\
\hline \multirow{2}{*}{$\begin{array}{l}\mathbf{S} \\
\mathbf{e} \\
\mathbf{x} \\
\mathbf{o}\end{array}$} & Mulher & $\begin{array}{c}63 \% \\
278 / 441\end{array}$ & {$[0,49]$} & \multirow[t]{2}{*}[2]{} & $\begin{array}{c}58,4 \% \\
101 / 173\end{array}$ & {$[0,64]$} & \multirow[t]{2}{*}[38]{} & $\begin{array}{c}66 \% \\
177 / 268\end{array}$ & {$[0,54]$} & \multirow[t]{2}{*}{ [9] } \\
\hline & Homem & $\begin{array}{c}52,1 \% \\
174 / 334 \\
\end{array}$ & {$[0,51]$} & & $\begin{array}{l}33,3 \% \\
34 / 102 \\
\end{array}$ & {$[0,26]$} & & $\begin{array}{c}51,3 \% \\
140 / 273 \\
\end{array}$ & {$[0,45]$} & \\
\hline \multirow{2}{*}{$\begin{array}{l}\mathbf{N} \\
\mathbf{a} \\
\mathbf{c}\end{array}$} & Brasileiro & $\begin{array}{c}63,4 \% \\
317 / 500\end{array}$ & {$[0,52]$} & [7] & & se apli & & & se apli & \\
\hline & Uruguaio & $\begin{array}{c}49,1 \% \\
135 / 275\end{array}$ & {$[0,45]$} & & & & & & & \\
\hline $\mathbf{T}$ & & $\begin{array}{c}58,3 \% \\
452 / 775\end{array}$ & & & $\begin{array}{c}49,1 \% \\
135 / 275\end{array}$ & & & $\begin{array}{c}63,4 \% \\
317 / 500\end{array}$ & & \\
\hline In & & & 0,62 & & & 0,50 & & & 0,68 & \\
\hline
\end{tabular}

Nessas análises sem os casos categóricos, a diferença fundamental está na faixa etária e no tempo verbal/saliência. O padrão da mudança linguística por meio da faixa 
etária mais jovem, agora, encontra-se completamente similar nas três análises. No caso do tempo verbal, em termos de diferenças linguísticas, no português uruguaio, gerúndio/ infinitivo desfavorecem a gente, enquanto pretérito perfeito sem neutralização favorece o mesmo pronome. O contrário ocorre na análise brasileira. De qualquer forma, é importante frisar que são pouquíssimos dados.

Em termos de range, temos 92,9 e 64 para o paralelismo, 50 e 29 para o preenchimento do sujeito, 71 e 43 para o tempo verbal, [10] e 16 para a referência, 41 e 45 para a idade. Os primeiros valores de cada par são do PU e os segundos valores do PB.

Assim, a diferença está apenas na análise uruguaia sem os casos categóricos, porque na análise brasileira há pouquíssimas diferenças de range. A faixa etária agora quase se iguala, com o mesmo padrão etário tanto no português uruguaio (de 20 para 41) como no português brasileiro da fronteira (de 42 para 45). O tempo verbal deixa de ser idêntico e a passa a ter uma diferença maior no PU (de 43 para 71). Os primeiros valores são da análise uruguaia com todos os falantes e os segundos valores são da análise uruguaia sem os casos categóricos. As variáveis linguísticas que permanecem semelhantes são o paralelismo e o tipo de sujeito.

Adiante, na Tabela 18, reproduzimos apenas os pesos relativos de todas as análises (com todos os colaboradores e sem os dados categóricos de nós) apenas para reforçar a semelhança do português brasileiro da fronteira e do português uruguaio da fronteira na maioria das variáveis e fatores linguísticos e sociais.

Tabela 18: Comparação das variáveis sociais nas três análises com peso relativo (com todos os dados e sem os dados categóricos de nós)

\begin{tabular}{|c|c|c|c|c|c|c|c|}
\hline \multirow{2}{*}{\multicolumn{2}{|c|}{$\begin{array}{l}\text { Variável } \\
\text { Fatores }\end{array}$}} & \multicolumn{2}{|c|}{ PB e PU de Aceguá } & \multicolumn{2}{|c|}{ PU de Aceguá } & \multicolumn{2}{|c|}{ PB de Aceguá } \\
\hline & & Com todos & Sem os & Com todos & Sem os & Com todos & Sem os \\
\hline \multirow{3}{*}{$\begin{array}{l}\text { I } \\
\text { d } \\
\text { a } \\
\text { d } \\
\text { e }\end{array}$} & 15 a 25 anos & 0,58 & 0,74 & 0,44 & 0,81 & 0,77 & 0,76 \\
\hline & 31 a 49 anos & 0,50 & 0,45 & 0,63 & 0,42 & 0,42 & 0,44 \\
\hline & Acima de 50 anos & 0,41 & 0,35 & 0,43 & 0,40 & 0,35 & 0,31 \\
\hline \multirow{2}{*}{$\begin{array}{l}\mathbf{S} \\
\mathbf{e} \\
\mathbf{x}\end{array}$} & Mulher & {$[0,53]$} & {$[0,49]$} & {$[0,47]$} & {$[0,64]$} & {$[0,54]$} & {$[0,48]$} \\
\hline & Homem & {$[0,45]$} & {$[0,51]$} & {$[0,53]$} & {$[0,26]$} & {$[0,45]$} & {$[0,51]$} \\
\hline \multirow{2}{*}{$\begin{array}{l}\mathbf{N} \\
\mathbf{a} \\
\mathbf{c}\end{array}$} & Brasileiro & 0,62 & {$[0,52]$} & \multirow{2}{*}{\multicolumn{2}{|c|}{ Não se aplica }} & \multirow{2}{*}{\multicolumn{2}{|c|}{ Não se aplica }} \\
\hline & Uruguaio & 0,35 & {$[0,45]$} & & & & \\
\hline \multicolumn{2}{|c|}{ Input } & 0,42 & 0,62 & 0,18 & 0,50 & 0,62 & 0,68 \\
\hline
\end{tabular}


Em termos de peso relativo, sobretudo de todas as análises sem os casos categóricos, os resultados dos fatores sociais são muito próximos em ambos os lados da fronteira. Esses resultados semelhantes justificam a análise geral com todos os colaboradores juntos (brasileiros e uruguaios).

A faixa etária é exatamente a mesma na análise uruguaia e na análise brasileira sem os casos categóricos, ou seja, os jovens da fronteira também favorecem o uso de $a$ gente. Analisando o efeito diferente do padrão etário uruguaio com todos os colaboradores e sem os casos categóricos, percebe-se que as comunidades (uruguaia e brasileira) estão em semelhantes trajetórias, já que ambas estão mais em movimento de mudança, a partir dos jovens como favorecedores de a gente.

A mudança no português uruguaio acontece de duas maneiras (i) no indivíduo, de forma instável, pois na análise uruguaia com todos os colaboradores são os adultos que usam mais a gente em função do mercado de trabalho, viagens e de outros fatores de mobilidade social; (ii) a mudança na comunidade, pois, na análise uruguaia sem os casos categóricos, o padrão da faixa etária passa a ser idêntico ao padrão brasileiro, com os jovens utilizando mais a gente. Segundo Weinreich, Labov, Herzog (2006, p. 149),

as mudanças em $\mathrm{S}$ dentro de uma geração [...] são possíveis mas necessariamente diminutas. Elas alcançam proporções maiores somente quando a curva em $\mathrm{S}$ coincide com uma mudança nas gerações. Se a mudança já tiver abarcado a maioria, então os jovens 'naturalmente' acompanharão (isto é, eles se tornam a ponta final do S). Mas mesmo que uma maioria ainda esteja resistindo à mudança, esta maioria acabará morrendo.

Assim, como no português uruguaio o pronome a gente está em 49,1\%, é provável que, conforme aumente a percentagem global dos dados, mais jovens comecem naturalmente a inserir o pronome a gente em sua fala com base na afirmação de Weinreich, Labov e Herzog (2006, p. 149).

Já a mudança no português brasileiro da fronteira parte da comunidade nos dois tipos de análise, de forma mais estável, e está relativamente mais avançada do que no português uruguaio apenas por uma questão de distribuição dos dados e também porque o pronome a gente é mais antigo na variedade linguística brasileira.

Por se tratar de uma mudança linguística rumo ao uso cada vez maior de um pronome (a gente) inovador, prestigiado, prototípico do português monolíngue, brasileiro e dos jovens, é importante discutir os conceitos labovianos de change from 
below (mudança sem consciência social) e change from above (mudança com consciência social) (LABOV, 1972, p. 123; LABOV, 2001, p. 272-284).

A mudança sem consciência social ou change from below seria interna e natural à própria variedade linguística em questão, como é o caso do português brasileiro da fronteira, uma vez que o a gente já pertencia à língua desde o português arcaico e se gramaticalizou em pronome. No caso do português uruguaio da fronteira, a mudança parece acontecer mais com consciência social ou change from above, uma vez que o pronome a gente ainda não havia sido registrado nesse falar uruguaio e é um ideal prestigiado, urbano e típico da variedade monolíngue brasileira, sendo, portanto, externo à variedade em uso.

Com uma interpretação menos polarizada e mais relativizada, a variação pronominal de primeira pessoa do plural também pode refletir uma mudança sem consciência em ambos os lados da fronteira, visto que se trata provalmente de um fenômeno não estigmatizado (ZILLES, 2007, p. 37) tanto no português uruguaio como no português brasileiro da fronteira em Aceguá. A partir da inserção de a gente no português uruguaio, o pronome começa a avançar e expandir de forma natural nas mesmas variáveis linguísticas e sociais conforme acontece no português brasileiro.

No português brasileiro de Aceguá, a mudança está em progresso, tanto na análise com todos os falantes como sem os dados categóricos de nós, ou seja, a mudança já atingiu a comunidade, como acontece de uma forma geral em outras variedades do português brasileiro. Mesmo com a retirada de alguns falantes que usam categoricamente o nós, esse padrão etário permanece o mesmo, com os jovens favorecendo o uso do pronome a gente.

No português uruguaio de Aceguá, ao fazer análises separadas, evidencia-se que há um grupo que revela mudança em função do tempo aparente e outro grupo que ainda não foi atingido pela mudança. $\mathrm{Na}$ análise com todos os falantes, a gradação etária provocada pelo efeito do mercado de trabalho aparece no padrão curvilinear, já que os adultos favorecem a gente em detrimento dos mais jovens e dos falantes de mais idade. Alguns jovens e adultos usam categoricamente nós pelas relações sociais mais intensas no Uruguai e pelo pouco ou nenhum contato com o Brasil. Segundo Meyerhoff (2006, p.145), a gradação etária é um termo que enfatiza justamente a variação que esá associada a indivíduos de diferentes faixas etárias.

$\mathrm{Na}$ análise sem os casos categóricos, os uruguaios também demonstram que a mudança linguística está em progresso no tempo aparente, o que indica uma mudança 
em andamento na comunidade, sendo os jovens os precursores pelo avanço do pronome a gente, assim como a análise brasileira.

Assim, em ambos os lados da fronteira, a mudança linguística está em progresso e em tempo aparente. Ao mesmo tempo, temos indícios de tempo real nos livros de Elizaincín, Behares e Barrios (1987, p. 85) e Elizaincín (1993, p. 81-85, 135-136) de que a variação pronominal de primeira pessoa do plural não existia no português uruguaio. Segundo Elizaincín et al (1987), no português uruguaio encontrado na década de 70, não havia o registro de a gente como pronome, mas apenas como terceira pessoa.

Para Meyerhoff (2006, p. 127), o tempo real envolve a comparação da forma como as pessoas falam em um ponto no tempo, como a maneira de falar de uma década, geração ou mais, ou seja, um estudo sincrônico com inferências de mudança. O tempo aparente reflete como os falantes de diferentes idades falam em uma comunidade em único tempo, ou seja, um estudo sincrônico que também pode mostrar inferências de mudança, porque parte da estrutura linguística se estabiliza a partir da idade crítica de aquisição de linguagem. Ainda para a Meyerhoff (2006, p. 127),

se os falantes mais jovens têm comportamento diferente dos falantes mais velhos, presumimos que a mudança tem ocorrido dentro da comunidade. $\mathrm{O}$ tempo aparente invoca o pressuposto de que os falantes somente mudam a maneira de falar minimamente depois do período crítico ou da idade adulta ${ }^{99}$ (Tradução nossa).

Labov (2008, p. 28-30), sobre Martha's Vineyard, combina resultados de tempo aparente e registros anteriores de um atlas dialetal, numa perspectiva de tempo real. Assim, comparou as informações e pode inferir melhor que a tendência geral é de que jovens centralizem mais os ditongos, especialmente se eles não tiverem um sentimento negativo sobre a ilha.

Sobre as outras variáveis sociais, o sexo não é selecionado em nenhuma análise, mas, se fosse selecionado, ou teria pesos muito próximos e, por isso, sem efeito estatístico, ou seria a mulher a favorecedora de a gente, sobretudo na análise uruguaia sem os dados categóricos, que têm um efeito forte e perto da seleção.

A nacionalidade é selecionada apenas na análise com todos os colaboradores, demarcando uma diferença distribucional de a gente entre uruguaios e brasileiros. No

\footnotetext{
99 "If younger speakers behave differently from older speakers, it is assumed that change has taken place within the community. The apparent time construct relies on the assumption that speakers only minimally change the way they speak after the critical period or in adulthood (MEYERHOFF, 2006, p. 127)
} 
entanto, quando os casos categóricos são retirados da análise, a nacionalidade é eliminada e não aparece como estatisticamente significativa. Isso é mais um indício de que a comunidade pode ser considerada bem coesa também nas questões de mudança linguística com a inserção, implementação e expansão de $a$ gente em ambos os lados da fronteira.

O resumo dos pesos relativos das variáveis linguísticas com e sem os dados categóricos de nós pode ser visto na Tabela 19.

Tabela 19: Comparação das variáveis linguísticas nas três análises com peso relativo (com todos os dados e sem os dados categóricos de nós)

\begin{tabular}{|c|c|c|c|c|c|c|c|}
\hline \multirow{2}{*}{\multicolumn{2}{|c|}{$\begin{array}{l}\text { Variável } \\
\text { Fatores }\end{array}$}} & \multicolumn{2}{|c|}{ PB e PU de Aceguá } & \multicolumn{2}{|c|}{ PU de Aceguá } & \multicolumn{2}{|c|}{ PB de Aceguá } \\
\hline & & Com todos & Sem os & Com todos & Sem os & Com todos & Sem os \\
\hline \multirow{6}{*}{$\begin{array}{l}\mathbf{P} \\
\mathbf{a} \\
\mathbf{r} \\
\mathbf{a} \\
\mathbf{l} \\
\mathbf{e} \\
\mathbf{l} \\
\mathbf{i} \\
\mathbf{s} \\
\mathbf{m} \\
\mathbf{o}\end{array}$} & $\begin{array}{l}\text { Não } 1^{\circ} \text { da série } \\
\text { precedido de } a \\
\text { gente explícito }\end{array}$ & 0,91 & 0,84 & 0,97 & 0,93 & 0,82 & 0,77 \\
\hline & $\begin{array}{l}\text { Não } 1^{\circ} \text { da série } \\
\text { precedido de } a \\
\text { gente implícito }\end{array}$ & 0,93 & 0,88 & 0,96 & 0,88 & 0,91 & 0,89 \\
\hline & $1^{\circ}$ da série & 0,41 & 0,39 & 0,45 & 0,34 & 0,42 & 0,42 \\
\hline & Isolado & 0,41 & 0,38 & 0,47 & 0,44 & 0,36 & 0,37 \\
\hline & $\begin{array}{l}\text { Não } 1^{\circ} \text { da série } \\
\text { precedido de nós } \\
\text { explícito }\end{array}$ & 0,20 & 0,23 & 0,17 & 0,14 & 0,24 & 0,25 \\
\hline & $\begin{array}{l}\text { Não } 1^{\circ} \text { da série } \\
\text { precedido de nós } \\
\text { implícito }\end{array}$ & 0,28 & 0,27 & 0,18 & 0,07 & 0,46 & 0,45 \\
\hline \multirow{2}{*}{$\begin{array}{l}\mathbf{S} \\
\mathbf{u} \\
\mathbf{j}\end{array}$} & Sujeito explícito & 0,61 & 0,59 & 0,69 & 0,67 & 0,57 & 0,56 \\
\hline & Sujeito implícito & 0,22 & 0,23 & 0,18 & 0,17 & 0,24 & 0,27 \\
\hline \multirow{6}{*}{$\begin{array}{l}\mathbf{T} \\
\mathbf{e} \\
\mathbf{m} \\
\mathbf{p} \\
\mathbf{o}\end{array}$} & $\begin{array}{l}\text { Presente com } \\
\text { neutralização }\end{array}$ & 0,68 & 0,74 & 0,67 & 0,83 & 0,69 & 0,70 \\
\hline & $\begin{array}{l}\text { Pretérito perfeito } \\
\text { com neutralização }\end{array}$ & 0,26 & 0,23 & 0,31 & 0,18 & 0,26 & 0,25 \\
\hline & $\begin{array}{l}\text { Presente sem } \\
\text { neutralização }\end{array}$ & 0,45 & 0,41 & 0,46 & 0,42 & 0,42 & 0,41 \\
\hline & $\begin{array}{l}\text { Pretérito perfeito } \\
\text { sem neutralização }\end{array}$ & 0,45 & 0,41 & 0,64 & 0,68 & 0,28 & 0,26 \\
\hline & Imperfeito & 0,36 & 0,36 & 0,24 & 0,12 & 0,43 & 0,44 \\
\hline & $\begin{array}{l}\text { Gerúndio } \\
\text { infinitivo }\end{array}$ & 0,55 & 0,56 & 0,45 & 0,46 & 0,63 & 0,57 \\
\hline $\begin{array}{l}\mathbf{R} \\
\mathbf{e}\end{array}$ & $\begin{array}{l}\text { Referência } \\
\text { genérica }\end{array}$ & {$[0,52]$} & 0,55 & {$[0,55]$} & {$[0,54]$} & 0,55 & 0,57 \\
\hline $\begin{array}{l}\text { f } \\
\text { e }\end{array}$ & $\begin{array}{l}\text { Referência } \\
\text { específica }\end{array}$ & {$[0,46]$} & 0,43 & {$[0,43]$} & {$[0,44]$} & 0,42 & 0,41 \\
\hline \multicolumn{2}{|c|}{ Input } & 0,42 & 0,62 & 0,18 & 0,50 & 0,62 & 0,68 \\
\hline
\end{tabular}


A variável linguística mais significativa é o paralelismo linguístico, visto que o não primeiro da série precedido de a gente implícito ou explícito favorece a gente em todas as análises de maneira similar.

O preenchimento do sujeito tem pouca diferença entre as análises com todos os colaboradores e a análise sem os casos categóricos, mostrando o forte condicionamento linguístico do sujeito explícito para o favorecimento do pronome a gente.

Sobre o tempo/saliência, há diferenças entre as análises no sentido de que (i) o fator pretérito perfeito sem neutralização favorece o pronome a gente na análise com uruguaios e desfavorece bruscamente na análise com brasileiros; (ii) o tempo gerúndio/infinitivo favorece $a$ gente na análise brasileira e desfavorece na análise uruguaia.

A semelhança do tempo verbal nas três análises é que o presente com neutralização favorece a presença de a gente. Quando há neutralização, os resultados para uruguaios e brasileiros são iguais, ou seja, favorecimento de a gente no presente com neutralização e desfavorecimento de a gente no pretérito perfeito com neutralização. Quando não há neutralização, as diferenças surgem, porque o presente sem neutralização desfavorece a gente em todas as análises, principalmente sem os categóricos, mas o pretérito perfeito sem neutralização favorece a gente na análise uruguaia e desfavorece na análise brasileira. Para o português uruguaio, o efeito do pretérito -mos é somente quando há neutralização. O português brasileiro continua mantendo a oposição de reservar -mos para pretérito perfeito.

O gerúndio/infinitivo no português uruguaio tem efeito intermediário e favorece $a$ gente no português brasileiro. O imperfeito desfavorece a gente em todas as análises, mas nesse corpus há muitos dados de nós no tempo do imperfeito, como "nós cantava", que também seguem o princípio do "evite proparoxítona". Só que o imperfeito no português brasileiro ainda tem um efeito levemente maior $(0,44)$ se formos comparar com o português uruguaio $(0,12)$, ambos da análise sem os casos categóricos.

Das variáveis linguísticas, o tipo de referência é apenas selecionado na análise brasileira, na qual o pronome a gente é favorecido nos contextos mais genéricos, confirmando uma das hipóteses iniciais, visto que a expressão gramaticalizada ainda guarda o traço de coletividade de quando era um sintagma nominal. Esse traço de indeterminação não é selecionado estatisticamente na análise uruguaia, mesmo tendo a expressão "la gente" no espanhol, que conserva apenas a interpretação genérica. Ainda assim, se essa variável fosse selecionada na análise uruguaia, teria os pesos semelhantes 
aos da análise brasileira e, portanto, favoreceria levemente a gente também na referência genérica $([0,55])$.

Em termos do tipo de referência, o português brasileiro da fronteira e o português uruguaio da fronteira têm resultados semelhantes aos outros trabalhos sobre o português brasileiro de outras localidades, favorecendo a gente em contextos mais genéricos, como destaca Omena (2003), dentre outros. No português europeu, como no português uruguaio, a variável tipo de referência não é selecionada, mas a frequência aponta para $a$ gente em contextos específicos, o inverso do Brasil e do norte do Uruguai. Isso nos mostra que a frequência de uso de a gente ainda está mais espraiada no português brasileiro e no português uruguaio (acréscimo meu) do que no português europeu, já que se encontra em contextos de usos mais generalizados e, portanto, mais gramaticalizados (RUBIO, 2012, p. 244 e 245).

A função sintática não foi inserida em nenhuma análise para análise de peso relativo, uma vez que só foram rodados os casos de sujeito para uma maior comparabilidade dos resultados e porque algumas análises com a função sintática deram não convergência. Segundo Guy e Ziles (2007, p. 57-60), uma distribuição desequilibrada pode não dar convergência e, no caso da função sintática, a grande quantidade de dados está concentrada na função de sujeito. Ainda assim, é importante analisarmos a distribuição dos dados para entender por qual função sintática a mudança linguística acontece primeiro com relação aos pronomes de primeira pessoa do plural.

$\mathrm{O}$ adjunto adnominal, adjunto adverbial, objeto direto e objeto indireto foram desmembrados em dois. Em um fator de cada uma dessas funções sintáticas, só há a codificação dos pronomes do caso reto a gente e nós e no outro fator há a presença dos pronomes oblíquos nos, no objeto indireto e direto, conosco, no adjunto adverbial, e o pronome possessivo nosso ou da gente, no adjunto adnominal. A Tabela 20 mostra a comparação da função sintática nas três análises de percentagem. 
Tabela 20: Comparação da variável função sintática com todos os dados das três análises da amostra de Aceguá em relação ao pronome a gente.

\begin{tabular}{|c|c|c|c|c|}
\hline & Fatores & PB e PU & PU & PB \\
\hline \multirow[t]{13}{*}{$\begin{array}{l}\text { Função } \\
\text { sintática }\end{array}$} & Sujeito & $\begin{array}{c}45,1 \% \\
452 / 1002\end{array}$ & $\begin{array}{c}29,3 \% \\
135 / 461\end{array}$ & $\begin{array}{c}58,6 \% \\
317 / 541\end{array}$ \\
\hline & $\begin{array}{l}\text { Elementos intercalados ou } \\
\text { resposta única }\end{array}$ & $\begin{array}{c}50 \% \\
15 / 30\end{array}$ & $\begin{array}{c}33,3 \% \\
4 / 8\end{array}$ & $\begin{array}{c}61,1 \% \\
11 / 18\end{array}$ \\
\hline & Tópico ou repetição de pronome & $\begin{array}{c}25 \% \\
1 / 4\end{array}$ & $\begin{array}{c}50 \% \\
1 / 2\end{array}$ & $\begin{array}{l}0 \% \\
0 / 2\end{array}$ \\
\hline & Objeto indireto (nós e $a$ gente) & $\begin{array}{c}17,6 \% \\
3 / 17\end{array}$ & $\begin{array}{c}25 \% \\
2 / 8\end{array}$ & $\begin{array}{c}11,1 \% \\
1 / 9\end{array}$ \\
\hline & $\begin{array}{l}\text { Objeto indireto (somente dados de } \\
\text { nos) }\end{array}$ & $\begin{array}{c}0 \% \\
0 / 18\end{array}$ & $\begin{array}{c}0 \% \\
0 / 13\end{array}$ & $\begin{array}{l}0 \% \\
0 / 5\end{array}$ \\
\hline & $\begin{array}{l}\text { Adjunto adverbial (com nós, com } \\
\text { a gente, para nós, para a gente, } \\
\text { pra nós, pra gente, entre nós) }\end{array}$ & $\begin{array}{c}16,7 \% \\
7 / 42\end{array}$ & $\begin{array}{c}14,3 \% \\
2 / 14\end{array}$ & $\begin{array}{c}17,9 \% \\
5 / 28\end{array}$ \\
\hline & $\begin{array}{l}\text { Adjunto adverbial (somente dados } \\
\text { de conosco) }\end{array}$ & $\begin{array}{l}0 \% \\
0 / 6\end{array}$ & $\begin{array}{l}0 \% \\
0 / 1\end{array}$ & $\begin{array}{l}0 \% \\
0 / 5\end{array}$ \\
\hline & $\begin{array}{l}\text { Adjunto adnominal (nosso, } d a \\
\text { gente) }\end{array}$ & $\begin{array}{l}4,8 \% \\
5 / 102\end{array}$ & $\begin{array}{c}2 \% \\
1 / 49\end{array}$ & $\begin{array}{l}7,5 \% \\
4 / 53\end{array}$ \\
\hline & $\begin{array}{l}\text { Adjunto adnominal (somente } \\
\text { apareceram dados de nós) }\end{array}$ & $\begin{array}{l}0 \% \\
0 / 2\end{array}$ & $\begin{array}{l}0 \% \\
0 / 0\end{array}$ & $\begin{array}{l}0 \% \\
0 / 2\end{array}$ \\
\hline & $\begin{array}{l}\text { Objeto direto (somente } \\
\text { apareceram dados de nós) }\end{array}$ & $\begin{array}{l}0 \% \\
0 / 3\end{array}$ & $\begin{array}{l}0 \% \\
0 / 0\end{array}$ & $\begin{array}{l}0 \% \\
0 / 3\end{array}$ \\
\hline & Objeto direto (nos) & $\begin{array}{l}0 \% \\
0 / 9\end{array}$ & $\begin{array}{l}0 \% \\
0 / 5\end{array}$ & $\begin{array}{l}0 \% \\
0 / 4\end{array}$ \\
\hline & Aposto & $\begin{array}{l}0 \% \\
0 / 2\end{array}$ & $\begin{array}{l}0 \% \\
0 / 1\end{array}$ & $\begin{array}{l}0 \% \\
0 / 1\end{array}$ \\
\hline & Complemento nominal & $\begin{array}{l}0 \% \\
0 / 3\end{array}$ & $\begin{array}{l}0 \% \\
0 / 0\end{array}$ & $\begin{array}{l}0 \% \\
0 / 3\end{array}$ \\
\hline $\begin{array}{l}\text { Total de } \\
\text { dados }\end{array}$ & & $\begin{array}{c}39 \% \\
483 / 1240 \\
\end{array}$ & $\begin{array}{c}25,6 \% \\
145 / 566\end{array}$ & $\begin{array}{c}50,1 \% \\
338 / 674\end{array}$ \\
\hline
\end{tabular}

As percentagens foram mantidas a fim de identificar a possível mudança via função sintática ou minimamente analisar quais as funções mais salientes para a presença dos pronomes de primeira pessoa do plural. Os totais de dados não são os mesmos das análises estatísticas, porque na tabela de função sintática o objetivo é mostrar todas as possibilidades de função que aparecem nos dados, sem retirada de nenhum deles ou amalgamações, mesmo porque os números são percentuais.

$\mathrm{Na}$ análise geral, em termos de frequência, há mais dados de a gente na função de sujeito $(45,1 \%)$ e na posição de elementos intercalados/dados truncados ou resposta única (50\%) em relação à média global (39\%). Nesse caso, dados de sujeito ocorrem mais e também favorecem um pouco, mas os intercalados ocorrem pouco e são os que mais favorecem a gente. Parece um contexto mais permeável, já que está fora da estrutura sintática. 
$\mathrm{Na}$ análise uruguaia, a distribuição também concentra-se na função de sujeito $(29,3 \%)$, elementos intercalados/dados truncados ou resposta única $(33,3 \%)$ e tópico/repetição do pronome (50\%), acima da média de $25,6 \%$. No entanto, há poucos dados desses dois últimos fatores, o que fortalece ainda mais a importância dos dados na função de sujeito. Abaixo da média, estão o adjunto adverbial (a gente) segue com $14,3 \%$ e o adjunto adnominal (da gente) com $2 \%$. No restante das funções, não há dados de $a$ gente, como adjunto adverbial (somente conosco), adjunto adnominal (outros tipos de dados sem ser da gente), objeto direto, aposto e complemento nominal.

$\mathrm{Na}$ análise brasileira, a função de sujeito $(58,6 \%)$ também é a mais produtiva com a maioria dos dados junto com elementos intercalados/dados truncados ou resposta única $(61,1 \%)$, ambos acima da média de 50,1\%. Abaixo da média estão o adjunto adverbial (a gente) com 17,9\%, o objeto indireto (a gente) com 11,1\%, e o adjunto adnominal (nosso, da gente) com 7,5\%. No restante das funções, não há dados de $a$ gente, como no adjunto adverbial (somente conosco), adjunto adnominal (outros tipos de dados sem ser da gente), objeto direto, aposto e complemento nominal.

Comparando os resultados dos brasileiros e dos uruguaios, percebe-se que os fatores da função sintática também são simétricos e caminham na mesma direção em ambas as análises, ou seja, na presença significativa, acima da média, de a gente na função de sujeito, elemento intercalado, e depois na presença tímida, abaixo da média, de a gente no adjunto adverbial, adjunto adnominal e objeto indireto. Nossos resultados são um pouco diferentes do que Omena (1996, p. 206) encontrou, pois, segundo a autora:

favorece o uso de a gente a função de adjunto adverbial e de complemento nominal. Na função de complemento verbal, tanto se usa a gente como nós (principalmente nas formas objetivas, preposicionadas ou não). Desfavorece esse uso de a gente a função de adjunto adnominal.

Para Omena (1996, p. 191), a mudança linguística começa pelas funções sintáticas de adjunto adverbial, sujeito e complemento, e começa a atingir o uso do possessivo na função de adjunto adnominal. Nos nossos dados, porém, apesar de não termos resultados em peso relativo, o maior índice de a gente está nas funções de sujeito, depois adjunto adverbial, objeto indireto e adjunto adnominal na análise brasileira. Já na análise uruguaia, a diferença é que o objeto indireto aparece com maior frequência do 
que o adjunto adverbial. Os elementos intercalados não têm uma função específica na sentença e os tópicos têm poucos dados.

Segundo Vianna e Lopes (2013, p. 34), há uma grande resistência para a entrada de a gente no sintagma nominal possessivo, porque "as relações internas ao sintagma nominal, principalmente quando são construções possessivas de adjunção (as mais frequentes na língua), assumem um caráter muito mais fixo (imutável) na organização do sistema". Por isso, talvez, essa posição mais sintática que discursiva favoreça "nosso ou nossa" em vez "da gente”. Em contrapartida, também para Vianna e Lopes (2013, p. 33), a porta de entrada para o pronome $a$ gente seria a de adjunto adverbial em função do status informacional que os elementos adquirem nessa posição, com a preferência de uso da construção "com a gente" em detrimento de "conosco".

No contexto geral de todas as variáveis analisadas comparativamente nas três análises e, em cada uma delas separadamente, de todos os colaboradores e sem os casos categóricos, nota-se que, apesar das possíveis diferenças entre o português uruguaio e o português brasileiro, como em qualquer variedade linguística, há certa autenticidade do português uruguaio como uma variedade do português brasileiro, tendo em vista os resultados tão simétricos quanto às variáveis linguísticas e sociais envolvidas na alternância de nós e a gente como primeira pessoa do plural.

É notório que há um padrão linguístico e social entre o português uruguaio da fronteira, português brasileiro da fronteira e outras variedades do português brasileiro como um todo, no sentido do mesmo uso dos pronomes nós e a gente como primeira pessoa do plural, o que corrobora também a proximidade dessas variedades linguísticas. Posto isso, retomamos a Tabela 1 (p. 117 e 118) para analisarmos agora onde se encaixam os resultados da comunidade de Aceguá, na região Sul, em comparação com outras regiões, em termos de frequência.

Tabela 21: Nós e a gente na região Centro-Oeste

\begin{tabular}{l|r|c}
\hline \multicolumn{1}{c}{ VARIEDADE CENTRO-OESTE } & A GENTE & NÓS \\
\hline Goiás - GO (MATTOS, 2013) & $77 \%$ & $23 \%$ \\
\hline Ponta Porã - MS - Comunidade de Assentados (MUNIZ, 2008) & $39 \%$ & $61 \%$ \\
\hline
\end{tabular}

Tabela 22: Nós e a gente na região Sudeste

\begin{tabular}{l|c|c}
\hline \multicolumn{1}{c}{ VARIEDADE SUDESTE } & A GENTE & NÓS \\
\hline Rio de Janeiro - Amostra Censo de 2000 - RJ (OMENA, 2003) & $79 \%$ & $21 \%$ \\
\hline Rio de Janeiro - Amostra Censo de 1986 - RJ (OMENA, 2003) & $78 \%$ & $22 \%$ \\
\hline Norte fluminense - RJ (MACHADO, 1995) & $73 \%$ & $27 \%$ \\
\hline Interior Paulista Iboruna - SP (RUBIO, 2012) & $73,8 \%$ & $26,2 \%$ \\
\hline Vitória - ES - Projeto PORTVIX (MENDONÇA, 2010) & $70,8 \%$ & $27,3 \%$ \\
\hline Rio de Janeiro - RJ (OMENA; BRAGA, 1996) & $70 \%$ & $30 \%$ \\
\hline
\end{tabular}


NURC - RJ (SILVA, 2010)

Brasilândia - SP - Comunidade de Periferia (COELHO, 2006)

\begin{tabular}{|l|l|}
\hline $63 \%$ & $37 \%$ \\
\hline $53 \%$ & $47 \%$ \\
\hline
\end{tabular}

Tabela 23: Nós e a gente na região Sul

\begin{tabular}{l|c|c}
\hline \multicolumn{1}{c}{ VARIEDADE SUL } & A GENTE & NÓS \\
\hline Pelotas - RS - Projeto VARX (BORGES, 2004) & $78 \%$ & $22 \%$ \\
\hline Florianópolis - SC - Projeto VARSUL (SEARA, 2000) & $72 \%$ & $28 \%$ \\
\hline Jaguarão - RS - Projeto VARX (BORGES, 2004) & $69 \%$ & $31 \%$ \\
\hline Porto Alegre - RS (ZILLES, 2007) & $69 \%$ & $31 \%$ \\
\hline Curitiba - PR (BORBA, 1993) & $64 \%$ & $36 \%$ \\
\hline ACEGUÁ - RS (PACHECO) - sem os dados categóricos de nós no PB & $\mathbf{6 3 , 4 \%}$ & $\mathbf{3 6 , 6 \%}$ \\
\hline Blumenau - SC (TAMANINE, 2002) & $60 \%$ & $40 \%$ \\
\hline Lages - SC (TAMANINE, 2002) & $58 \%$ & $42 \%$ \\
\hline ACEGUÁ - RS (PACHECO) - com todos dados do PB & $\mathbf{5 8 , 6 \%}$ & $\mathbf{4 1 , 4 \%}$ \\
\hline ACEGUÁ - RS/UY (PACHECO) - sem os dados categóricos de nós no PB & $\mathbf{5 8 , 3 \%}$ & $\mathbf{4 1 , 7 \%}$ \\
e no PU & & \\
\hline Blumenau - SC (SILVA, 2004) & $51 \%$ & $49 \%$ \\
\hline Concordia - SC (FRANCESCHINI, 2011) & $50 \%$ & $50 \%$ \\
\hline ACEGUÁ - UY (PACHECO) - sem os dados categóricos de nós no PU & $\mathbf{4 9 , 1 \%}$ & $\mathbf{5 0 , 9 \%}$ \\
\hline Chapecó - SC (TAMANINE, 2002) & $48 \%$ & $\mathbf{5 2 \%}$ \\
\hline ACEGUÁ - RS/UY (PACHECO) - com todos os dados do PB e do PU & $\mathbf{4 5 , 1 \%}$ & $\mathbf{5 4 , 9 \%}$ \\
\hline ACEGUÁ - UY (PACHECO) - com todos os dados do PU & $\mathbf{2 9 , 3 \%}$ & $\mathbf{7 0 , 7 \%}$ \\
\hline
\end{tabular}

Tabela 24: Nós e a gente na região Nordeste

\begin{tabular}{l|c|c}
\hline \multicolumn{1}{c}{ VARIEDADE NORDESTE } & \multicolumn{1}{c}{ A GENTES } \\
\hline $\begin{array}{l}\text { Caimbongo - Cachoeira - BA - C. rural afro-brasileira } \\
\text { (OLIVEIRA, 2008) }\end{array}$ & $85 \%$ & $15 \%$ \\
\hline João Pessoa - PB - Projeto VALPB (FERNANDES, 1999) & $79 \%$ & $21 \%$ \\
\hline $\begin{array}{l}\text { Piabas - BA - Comunidade rural de Anselino da Fonseca ou Caem } \\
\text { (SAMPAIO e LOPES,) }\end{array}$ & $62 \%$ & $38 \%$ \\
\hline $\begin{array}{l}\text { Cinzento - BA - Comunidade afro-brasileira (ANTONINO; BANDEIRA, } \\
\text { 2011) }\end{array}$ & $56 \%$ & $44 \%$ \\
\hline
\end{tabular}

Tabela 25: Nós e a gente no Português Europeu

\begin{tabular}{l|c|c}
\hline \multicolumn{1}{c}{ VARIEDADE PORTUGUES EUROPEU } & A GENTE & NÓS \\
\hline CRPC - Portugal (RUBIO, 2012) & $42 \%$ & $58 \%$ \\
\hline Funchal - PE (VIANNA, 2011) & $26 \%$ & $74 \%$ \\
\hline Cacém - PE (VIANNA, 2011) & $22 \%$ & $78 \%$ \\
\hline Oeiras - PE (VIANNA, 2011) & $9 \%$ & $91 \%$ \\
\hline
\end{tabular}

A hipótese é que a gente estaria mais avançado no português brasileiro de Aceguá do que no português uruguaio de Aceguá, em termos de frequência. No caso do português brasileiro de Aceguá (Rio Grande do Sul), a frequência de uso é de 58,6\% na análise com todos os colaboradores e 63,4\% na análise sem os casos categóricos de nós. Por isso, acompanha os altos índices de a gente na região Sul do Brasil, como Pelotas (78\%) e Florianópolis (72\%), Jaguarão (69\%), Porto Alegre (69\%), Curitiba (64\%) e Blumenau $(60 \%)$.

Já no português uruguaio, o uso de a gente é de $29,3 \%$ na análise com todos os colaboradores e 49,1\% na análise sem os casos categóricos de nós, pois se trata, provavelmente, de um fenômeno recém-chegado nessa variedade linguística mais 
conservadora, falada nos meios mais interioranos, e em geral distantes das tendências normativistas ou urbanizadoras do Brasil. Ainda assim, a frequência maior de a gente no português uruguaio da fronteira se aproxima dos resultados das variedades de Santa Catarina: Blumenau (51\%), Concordia (50\%) e Chapecó (48\%).

Outra comparação interessante é o paralelo entre a fronteira de Aceguá e a fronteira de Jaguarão. Essas fronteiras brasileiras têm as percentagens de 63,4\% (sem os falantes categóricos) e 69\%, respectivamente, para o pronome a gente, do lado brasileiro. A diferença geográfica das duas localidades é que em Aceguá a fronteira é seca, ou seja, não há acidentes geográficos entre Brasil e Uruguai, enquanto em Jaguarão os dois países são separados pelo Rio Jaguarão, e a comunicação entre as duas fronteiras se dá por meio da Ponte Internacional Mauá. No entanto, essa divisão geográfica parece não contribuir para diferenças percentuais maiores, uma vez que a frequência de uso do pronome a gente nas duas cidades é próxima.

O pronome a gente como traço mais urbano e tipicamente brasileiro chega até às fronteiras brasileiras e ultrapassa para o lado uruguaio, como o é o caso de Aceguá. A diferença social entre essas comunidades é que em Jaguarão a forma inovadora tem menos prestígio para a classe alta. Em Aceguá, ainda que não tenhamos codificado classe social, o pronome a gente é um traço urbano típico do português brasileiro monolíngue e, portanto, almejado por falantes bilíngues, ainda que inconscientemente, tanto que o uso é cada vez maior e menos estigmatizado.

Fazendo um paralelo com os resultados de outras regiões, além da região Sul, o percentual do português brasileiro da fronteira $(63,4 \%)$ se aproxima dos falantes do Rio de Janeiro (de $79 \%$ a 59\%), na região Sudeste. Já a frequência de 49,1\% do português uruguaio da fronteira se aproxima de comunidades mais isoladas e rurais como Brasilândia - SP no Sudeste (53\%) e Cinzento - BA no Nordeste (56\%). Ao mesmo tempo, Ponta Porã - MS, no Centro-Oeste, tem frequência ainda inferior, de 39\%, e Piabas-BA, no Nordeste, tem a maior frequência de todas essas comunidades mais isoladas, com 62\%. No caso de Salvador (37\%) e Porto Alegre (28\%), ambos do projeto NURC, as frequências são baixas porque trata-se apenas de falantes cultos, o que não retrata bem a realidade brasileira como um todo.

No Brasil, de uma forma geral, Caimbongo-Cachoeira-BA (85\%), João PessoaPB (79\%), Vitória-ES (70,8\%), Interior Paulista-SP (73,8\%), Goiás (73\%), Norte Fluminense (73\%), Rio de Janeiro (de 79\% a 63\%), Piabas-BA (62\%), Cinzento-BA (56\%) e Brasilândia-SP (53\%) são as localidades em que a implementação do pronome 
a gente como primeira pessoa do plural está bastante avançada, o que configura mudança linguística em progresso no Brasil, já que a variante a gente é predominantemente usada (de 60\%) em muitas regiões do Brasil. O estágio final dessa mudança seria o uso categórico de a gente. Em Portugal, é o contrário, pois a frequência de uso é maior para o pronome nós.

Mapa 3: Mapa da distribuição do pronome a gente no Brasil

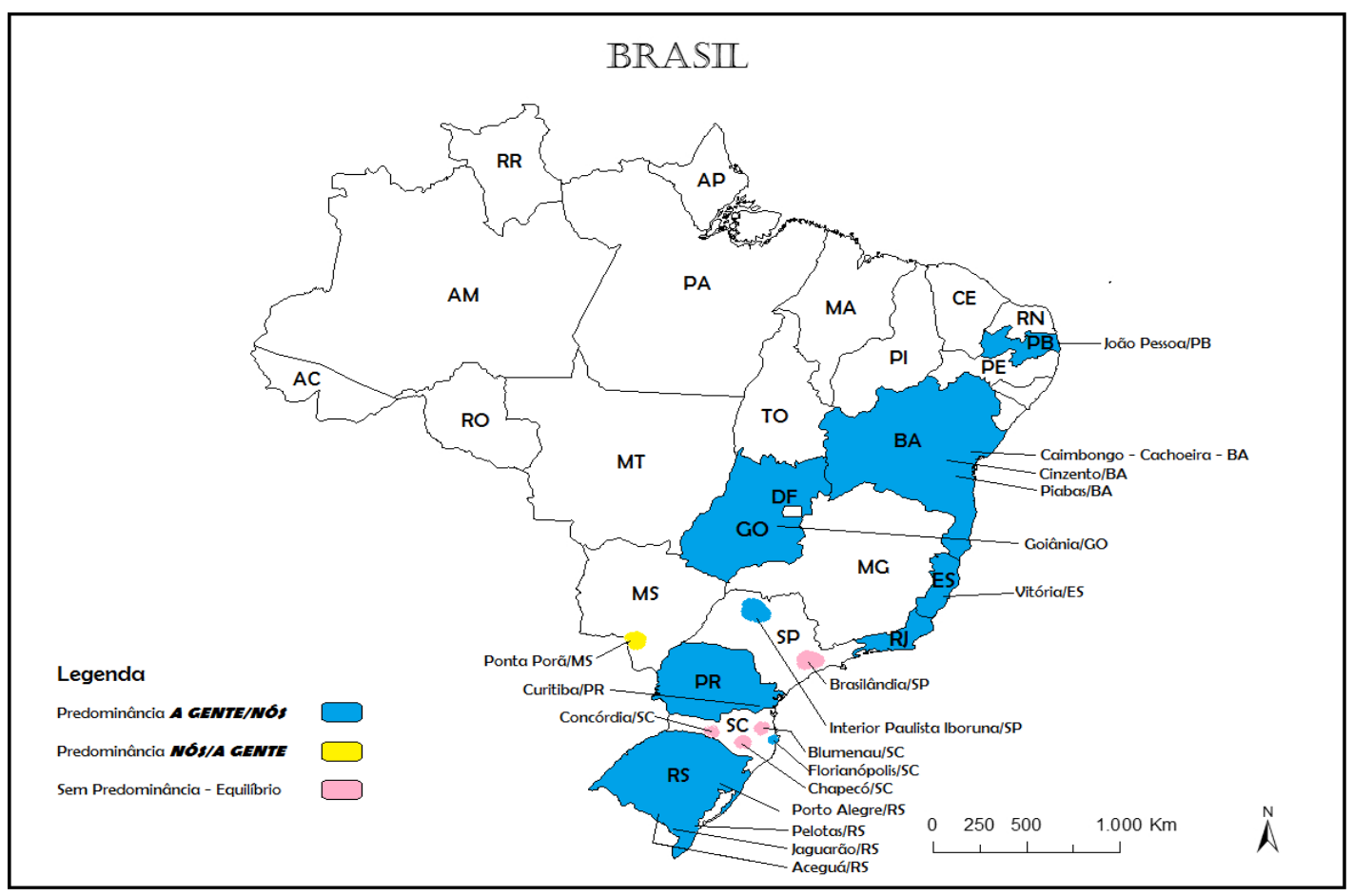

Fonte: Elaboração do autor (2014)

Em suma, no português brasileiro de Aceguá, a frequência de a gente chega a $63,4 \%$, e no português uruguaio de Aceguá chega a 49,1\%, ambas sem os falantes categóricos. Registra-se, pois, que a mudança linguística mais avançada no português dos brasileiros do ponto de vista distribucional, como na maior parte do Brasil, porque, com relação às variáveis linguísticas e à faixa etária, os dois lados da fronteira caminham de forma muito compartilhada.

Como os pronomes exercem a função, predominantemente, de sujeito, e são esses os dados rodados estatisticamente, analisamos, na próxima seção, como funciona também a concordância de número dos dados de sujeito com os pronomes nós e a gente como primeira pessoa do plural. O objetivo é entender a distribuição linguística dos pronomes do caso reto e do caso oblíquo dentro do português uruguaio e do português brasileiro da fronteira. 


\subsection{Variação na concordância de número no sintagma verbal}

Perini (2008, p. 124), de certa forma influenciado pela gramática tradicional, ao tratar da complexidade dos fatores semânticos, é cauteloso ao dizer que a concordância verbal é essencialmente o resultado de fatores semânticos, apesar de que há casos, incluindo nós e a gente, em que parece haver fatores não-semânticos também, mas que não têm sido devidamente estudados.

Perini (2008, p. 124) diz que nós é equivalente a eu e ele pela semântica dos elementos, porque nós é definido no léxico como eu mais outra(s) pessoa(s), o que inclui "eu e ele", ou seja, ambas as formas disparam a mesma marca de concordância. Ainda segundo Perini, é melhor assumir a concordância como um fenômeno semântico, porque as gramáticas consideram a concordância como um fenômeno sintático e analisam o pronome de primeira pessoa do plural como um caso de exceção à sintaxe, já que a concordância de nós e a gente é diferente.

No entanto, logo adiante, Perini (2008, p. 128) confirma a existência de fatores não-semânticos ao dizer que é difícil analisar o fenômeno nós e a gente do ponto de vista semântico, em decorrência do caráter marcado de primeira pessoa do plural (nós) e não marcado dos sufixos de terceira pessoa do singular (a gente).

\footnotetext{
Em termos de referência, nós e a gente se equivalem, e ambos incluem em sua extensão o falante, mais pelo menos uma pessoa. Ao que tudo indica, isso nos impede de descrever semanticamente essa diferença de sufixos. Por conseguinte, será necessário marcar o item a gente como uma exceção embora seja semanticamente "primeira pessoa", é formalmente terceira.
}

Ainda assim, em pesquisas sobre essa variação, constata-se que a concordância com os pronomes de primeira pessoa do plural também é variável, como nos exemplos nós vai, nós vamos, a gente vai, a gente vamos. Logo, os sufixos transitam pelas variantes dos pronomes plurais. A partir dessa realidade linguística, nota-se que essa concordância se manifesta por meio da sintaxe e da semântica.

Sobre a concordância de número, não há nenhum dado no português aceguaense de a gente + verbo no plural. Já dados de nós + verbo no singular são bem recorrentes. Rona (1965, p. 12), quando fala da coexistência sincrônica das "mesclas" entre português e espanhol, cita o caso nós tinha, nosotros teníamos o nosotros tenía. 
persona de plural, no una forma portuguesa determinada, puesto que se emplea también nos tenía (o teniba) y aun nosotros tenía o nosotros tinha. ( $\mathrm{p}$. 12-13).

Esse fenômeno (nós tinha) é conhecido como paroxitonização, ou seja, o falante tende a transformar as proparoxítonas em paroxítonas, porque estas últimas são bem mais comuns e naturais para a língua portuguesa. A partir dessa observação, Rona (1965, p. 12-13) assinala que há variação de número tanto no português riograndense falado pelos uruguaios quanto no espanhol da fronteira uruguaia. Para nosso trabalho, consequentemente, pode-se pressupor essa mesma variação no português uruguaio de Aceguá.

Elizaincín (1992, p. 121 e 123) pondera que o espanhol e o português "son lenguas que marcan redundantemente el plural en varios constituyentes de la oración: artículo, adjetivo, sustantivo, verbo... se observa en el mundo hispánico una tendencia cada vez mayor a simplificar la referencia múltiple a la pluralidad". Para o autor, citando Vázquez Cuesta y Mendes da Luz (1971, I, p. 143), no espanhol do Uruguai e no português do Brasil, a ausência de concordância é relativamente comum no estilo informal, diferentemente de Portugal. Ainda segundo Elizaincín (1992, p. 123), nos DPUs, as gerações mais jovens $(80 \%)$ evidenciam uma maior tendência a não concordância. Não se pode esquecer que geralmente os moradores da fronteira que falam português são provenientes da zona rural. As próprias pesquisas (SCHERRE e NARO, 2014) vêm afirmando que nas áreas urbanas o índice de concordância é bem maior.

No caso da concordância de número, há em Aceguá apenas a realização da variável de nós associada à terceira pessoa do singular ou à primeira pessoa do plural. Nos dados explícitos de a gente, só há dados de concordância de número padrão, ou seja, sempre na terceira pessoa do singular.

Entrevistado: NÓS TEMO uma ótima Educação hoje aqui. As escolas do interior tu não sabe o que é. Te digo, a área rural mesmo, o nível da escola da Nossa Senhora aqui, Municipal, tu vai no interior é a mesma coisa.

Entrevistador: É mesmo?

Entrevistado: Sim. Eu não conhecia e faz bem pouquinho que eu fui. Porque como eu trabalho no Rotary, A GENTE TRABALHA para dar brinquedos no Natal do Pampa aqui, AJUDA A COMPRAR cadeira de roda, EMPRESTAMO para os outros, então, vai tudo para essas causas. Aí, NÓS DECIDIU TRAZER para o interior, conhecer para dar umas cestas básicas. Aí A GENTE foi conhecer o interior. E isso é ótimo, porque A GENTE MORA aqui e NÃO SE DÁ CONTA do que tem no interior né?

(ROT, mulher, adulta, uruguaia, ensino médio) 
Nesse exemplo, há dados com nós explícito e a forma verbal singular ( $A i$, nós dediciu trazer para o interior) e a forma verbal plural (Nós temo uma ótima educação hoje aqui). No caso de $A$ gente explícito, só há exemplos com concordância no singular, ou seja, com verbo na forma verbal singular (A gente trabalha / Aí a gente foi conhecer o interior/A gente mora aqui e não se dá conta). A partir disso, partimos do pressuposto de que os sujeitos implícitos com verbo no singular seriam associados ao pronome $A$ gente ou nós a depender das marcas no contexto, ou seja, se o dado anterior tem a gente explícito (a gente mora aqui e não se dá conta do interior do que tem no interior né?) interpreta-se o próximo dado implícito como a gente (e a gente não se dá conta do interior). Já o sujeito implícito com verbo no plural ou desinência -mo(s) (emprestamo) seria associado exclusivamente ao pronome nós, porque não temos exemplos de $A$ gente mais verbo no plural. As possibilidades de concordância de número com os pronomes de primeira pessoa do plural no português brasileiro e no português uruguaio de Aceguá são:

\section{- A GENTE + CANTA/CANTAVA/CANTOU}

As pessoas definiram muito mais a língua. Ou é o Uruguaio... Ainda existe assim, A GENTE QUE ENTREVERA, como A GENTE DIZ. Mas e muito mais...

(FLA, mulher, 31 a 49 anos, brasileira, ensino superior)

Entrevistadas: A GENTE estava vendo relevos e planícies do Rio Grande do Sul.

(MAI, mulher, 15 a 30 anos, brasileira, ensino médio)

A GENTE já acostumou. Dá pra entender. E ele fala muito rápido.

(MAI, mulher, 15 a 30 anos, brasileira, ensino médio)

\section{- NÓS + CANTAMOS}

Entrevistada: Bastante, totalmente. Vamos dizer que é o entrevero dos dois, é a mistura dos dois. Porque, por exemplo, até mesmo, quando fala assim: NÓS TEMOS um piquete de carreta andarenga. O que é carreta? É carro de boi, carreta. Andarenga já é um termo que não existe nem no Brasil, nem no Uruguai.

(FLA, mulher, 31 a 49 anos, brasileira, ensino superior)

\section{- NÓS + CANTAMO}

NÓS TIVEMO uma reunião.

(ELE, mulher, de 31 a 49 anos, uruguaia, ensino médio) 


\section{- NÓS + CANTA/CANTAVA/CANTOU}

Não, tem que dobrar... É, antes NÓS TEM que ... trocar o percurso depois, não é só na mesma faixa, depois TROCA de fixa de novo.

(ALE, homem, 15 a 30 anos, uruguaio, ensino médio)

chama, e aí NÓS TAVA tomando um abacaxi assim com caña,

(EDI, homem, 31 a 49 anos, brasileiro, ensino superior)

Piorou, piorou, piorou. Porque antes entrou o MERCOSUL, aí NÓS ESTRAGOU muito...

(MAN, homem, acima de 50 anos, brasileiro, ensino fundamental)

\section{- NÓS + CANTEMO}

Entrevistado: Bah, quando eu tenho que falar espanhol, é muito. Agora, no caso, estão fazendo no Uruguai o censo. E eu peguei pra trabalhar. Então, agora, semana que vem NÓS COMECEMO, e o meu espanhol era um espanhol só em casa, e quando vem algum primo meu uruguaio. E nada mas.

(FLO, mulher, de 15 a 30 anos, uruguaia, ensino médio)

- $\varnothing+$ CANTAMOS

Já VIAJAMOS para lá. Porque é bem interessante daí. Vou deixar crescer a massa que ela já se firma.

(FLA, mulher, de 31 a 49 anos, brasileira, ensino superior)

\section{- $\emptyset+$ CANTAMO}

NÓS NÃO TEMO índio.

(ALE, homem, acima de 50 anos, uruguaio, ensino médio)

\section{- $\emptyset^{100}+$ CANTA/CANTAVA/CANTOU}

A gente faz escrita, a gente faz produções textuais, a gente olha todos os gêneros, então, a gente faz, SABE o paralelismo ou não, TENTA expressar em português, mas sempre o foco é comunicativo. A intenção é comunicativa.

(CAR, mulher, de 31 a 49 anos, brasileira, ensino superior)

E aí nós tava tomando um abacaxi assim com caña, e TAVA com canudo de taquara de cana mesmo assim.

(EDI, homem, 15 a 30 anos, brasileiro, ensino superior)

A gente se endividou na época, SE ENDIVIDOU, aqui não fui só eu, vários empresários.

(MAN, homem, acima de 50 anos, brasileiro, ensino fundamental)

\section{- $\varnothing+$ CANTEMOS}

Sim, TEMOS aqui do lado brasileiro tem uruguaios também como NÓS também.

\footnotetext{
${ }^{100} \varnothing$ significa sujeito implícito.
} 


\section{- $\emptyset+$ CANTEMO}

Mas NO PODEMO FAZER isso.

(RAD, mulher, acima de 50 anos, uruguaia, ensino médio)

Como não há dados de a gente mais verbo na primeira pessoa do plural, os dados de sujeito implícito que têm concordância estão sendo associados ao pronome nós. O caso de nós já é variável em terceira pessoa do plural e do singular. Levando em consideração as várias desinências de concordância (-mos, -mo, -emo) e a categoricidade da presença da concordância com a gente, a hipótese é que haja mais dados de concordância padrão na comunidade como um todo, seja com nós, seja com $a$ gente.

O objetivo dessa variável, portanto, é controlar o número de dados das diversas combinações entre concordância de número e o tipo de sujeito (se nós ou a gente implícito ou nós ou a gente explícito). Como também controlamos o preenchimento do sujeito, retiramos a concordância de número da análise geral dos dados do capítulo 5 . Posto isso, na Tabela 26, o pronome nós, a gente ou zero significa o preenchimento ou a ausência do sujeito, e o verbo em seguida mostra o tipo da concordância verbal.

Tabela 26: Tipos de concordância de número no português brasileiro e no português uruguaio da amostra de Aceguá

\begin{tabular}{|c|c|c|c|c|}
\hline $\begin{array}{l}\text { Concordância } \\
\text { de número }\end{array}$ & $\begin{array}{r}\text { Fatores } \\
\end{array}$ & PB e PU & PU & PB \\
\hline \multirow[t]{11}{*}{$\begin{array}{l}\text { Concordância } \\
\text { de número }\end{array}$} & $\begin{array}{l}\text { A gente canta/cantava/ } \\
\text { cantou }\end{array}$ & 393 dados & 111 dados & 282 dados \\
\hline & Nós cantamos & 143 dados & 52 dados & 91 dados \\
\hline & Nós cantamo & 125 dados & 96 dados & 29 dados \\
\hline & $\begin{array}{l}\text { Nós } \\
\text { canta/cantava/cantou }\end{array}$ & 49 dados & 22 dados & 27 dados \\
\hline & Nós cantemo & 36 dados & 26 dados & 10 dados \\
\hline & $\varnothing$ Cantamos & 57 dados & 39 dados & 18 dados \\
\hline & $\varnothing$ Cantamo & 95 dados & 70 dados & 25 dados \\
\hline & $\varnothing$ Canta/cantava/cantou & $\begin{array}{l}59 / 83=71,1 \% \\
\text { de } a \text { gente } \\
24 / 83=28,9 \% \\
\text { de } \text { nós }\end{array}$ & $\begin{array}{l}24 / 32=75 \% \\
\text { de } a \text { gente } \\
8 / 32=25 \% \\
\text { de nós }\end{array}$ & $\begin{array}{l}35 / 51=68,6 \% \\
\text { de } a \text { gente } \\
16 / 51=31,4 \% \\
\text { de } n o ́ s\end{array}$ \\
\hline & $\varnothing$ Cantemos & 1 dado & 0 dados & 1 dados \\
\hline & $\varnothing$ Cantemo & 19 dados & 12 dados & 7 dados \\
\hline & $\varnothing$ Samo (verbo ser) & 1 dado & 1 dados & 0 dados \\
\hline $\begin{array}{l}\text { Total de } \\
\text { dados }\end{array}$ & & 1002 dados & 461 dados & 541 dados \\
\hline
\end{tabular}

Conforme a Tabela 26, o único fator variável é quando o sujeito está implícito e o verbo está no singular como Ø Canta (zero ... zero), já que os demais fatores estão em 
distribuição complementar em relação à concordância. Nessa codificação, partimos do contexto linguístico para inferir quando se tratava de a gente ou nós, ou seja, identificamos a gente ou nós dependendo da presença de um desses pronomes anteriormente e/ou posteriormente no discurso, tendo o paralelismo linguístico como apoio na interpretação dos zeros como sujeito.

Assim, a presença de a gente no dado anterior nos faz pressupor que o sujeito do verbo "sabe" e "tenta" também é o pronome a gente (A GENTE FAZ, SABE o paralelismo ou não, TENTA expressar em português, mas sempre o foco é comunicativo. A intenção é comunicativa.). Da mesma forma acontece com o nós implícito antecedido de um nós explícito (Mas NÓS não, NÓS TEMO a televisão que desde pequeno, CRESCE, NASCE OIANDO TV, é diferente).

Logo, no português uruguaio e no português brasileiro da fronteira, não há dados de a gente com o morfema -mos, por isso os dados de sujeito implícito que têm concordância plural foram associados exclusivamente ao pronome nós, o que aumenta a probabilidade da concordância nessa comunidade de fala. $\mathrm{O}$ caso de nós já é variável em terceira pessoa do plural (NÓS TEMOS um piquete de carreta andarenga) e singular (NÓS TAVA tomando um abacaxi assim com caña). Cabe acrescentar que a frequência de concordância padrão é de 93,4\% para os uruguaios e de $83,6 \%$ para os brasileiros. Provavelmente a alta concordância do português na fronteira de Aceguá seja reflexo da alta concordância do espanhol como um todo.

De maneira geral, a concordância padrão do sujeito implícito + desinência de terceira pessoa do singular é mais preenchida pelo pronome a gente em todas as análises. Assim, no português uruguaio e no português brasileiro da fronteira, o índice de concordância é mais alto que no restante do Brasil, tanto que não há dados de a gente cantamos e os dados de nós canta são poucos (22 dados do PU e 27 dados do PB).

Levando em consideração as várias desinências de concordância (-mos, -mo, emo) e a concordância singular categórica com o pronome a gente, a hipótese é que haja mais concordância de número do que ausência de concordância na comunidade como um todo, porque, a exemplo do título do livro de Elizaincín, Behares e Barrios (1987), "Nós falemo brasileiro", a conjugação "nós falemo" é frequente em Aceguá. Ainda que não seja uma concordância padrão, a desinência -mo também é uma marca de plural.

De um total de 56 dados de "nós falemo(s)" e "falemo", 38 dados (67\%) são do português uruguaio de Aceguá e 18 dados (33\%) são do português brasileiro de Aceguá. Desses dados, 10 são de pretérito perfeito com neutralização, 36 de presente com 
neutralização, e 10 de presente sem neutralização ( 7 dados de semo e 3 de temo (da simplificação tamo do verbo estamos)). No total, seriam 46 dados de presente $(82,2 \%)$ e apenas 10 dados de pretérito perfeito $(17,8 \%)$, o que é bem diferente do que acontece nos dialetos mais rurais do Brasil, já que o -emo aparece como uma especialização do tempo pretérito para se distinguir do tempo presente com -amo. No português europeu, também há o registro de -emos no pretérito perfeito e no presente.

No tempo pretérito, segundo Leite de Vasconcellos (1987, p.112), é muito frequente na primeira conjugação, por analogia com a primeira pessoa do singular (-ei). Mira (1954, p.115) registra exemplos como estranhemos (pret. perf. simples) na fala popular de Lisboa.

No tempo presente, Leite de Vasconcellos (1987, p.111) registra -emos (amemos) no tempo verbal do presente em grande parte do país, principalmente ao Norte, mas também ao Sul de Portugal. Ratinho (1959, p.196) afirma que a $1^{\text {a }}$ pessoa do plural do presente do indicativo da $1^{\mathrm{a}}$ conjugação apresenta a terminação -emos em alternância com -àmos: Levemos/levàmos”. Cruz (1991, p.117) confirma que, por analogia com os verbos da $2^{\mathrm{a}}$, os verbos da $1^{\mathrm{a}}$ conjugação, na $1^{\mathrm{a}}$ pessoa do plural do presente do indicativo, apresentam frequentemente a terminação -emos em vez de-amos como chamemos, enjoelhemos, arragemos. ${ }^{101}$

A variante nós, em ambos os lados da fronteira, compartilha contextos de uso e semelhanças estruturais. A forma "trabalhemo" ou "nós trabalhemo" é uma característica típica da região fronteiriça do Brasil-Uruguai, e pode ser interpretada como um traço de regiões tipicamente rurais, como é o caso de Aceguá, frequente tanto no português brasileiro rural como no espanhol uruguaio rural, conforme Elizaincín (1992, p 183), baseado em Melo (1975), relata:

\footnotetext{
la forma "semo(s)" no aparece regularmente documentada en el corpus DPU; sin embargo, por nuestro conocimiento del español uruguayo rural podemos asegurar que es vital y muy extendida. Si esto es así, puede pensarse que el rasgo en cuestión, esto es (somos semos), presente en el español del Uruguay, puede actuar por analogia sobre las formas de la $4^{\mathrm{a}}$ persona de los verbos en -ar; a ello, puede sumarse la analogia de las formas correspondientes de los verbos de la segunda conjugación; y - no por fin - la presencia de $-\mathrm{a}->$-e- em muchas variedades del português brasileño.
}

\footnotetext{
${ }^{101}$ As informações sobre -emo no português europeu foram reunidas e fornecidas por Marta Scherre em comunicação pessoal.
} 
Elizaincín (1992, p. 125-126) incluiu em sua pesquisa Aceguá e Isidoro Noblía ${ }^{102}$, e identificou, de 10 dados coletados, 5 (50\%) verbos como "trabalhamo" e 5 (50\%) como "trabalhemo". No entanto, sabe-se que esse tipo de concordância verbal é recorrente em outras localidades, especialmente em áreas rurais tanto do Brasil quanto do Uruguai.

A variabilidade é medida pela diferença entre os dois percentuais, cada um com um exemplo direcionado a uma língua alvo. Nesse caso, a subtração de $50 \%$ por $50 \%$ é igual a 0 , número que simboliza a máxima variabilidade. Assim, há grande variação, porque, no total dos dados, não há nenhum grupo que está mais perto do português ou mais perto do espanhol do que o outro numa escala de continuum, por exemplo. A distância de ambos é a mesma. Novamente, Elizaincín afirma que os verbos citados manifestam traços diferentes, porque um é de base lusitana e o outro um avanço do espanhol. Todavia, se esquece de que ambas as variantes co-ocorrem também em áreas rurais do Brasil.

Para Elizaincín (1992, p.126), tanto "trabalhemo"103 como "trabajemo" podem ser interpretados como casos de quarta pessoa do perfeito simples, dada a semelhança que espanhol e português apresentam nessa pessoa, visto que esse tempo aparece no mesmo fenômeno da mudança da vogal temática. Segundo o autor (1992, p. 125), essa variabilidade acentuada (metade dos dados de cada tipo) pode indicar que se trata de um fenômeno (trabalhemo e trabajemo) relativamente recente na estrutura emergente dos DPUs.

De 38 entrevistas (19 com brasileiros e 19 com uruguaios) feitas em Aceguá, 3 brasileiros e 3 uruguaios utilizam essa forma verbal. Como exemplo de -emo no tempo presente no português brasileiro e uruguaio, temos:

Tá. Então aqui, por exemplo, no Uruguai, hoje em dia no Uruguai, vamos dizer que, do México pra baixo, as pessoa lá, como por exemplo, os mexicano, a mesma coisa que NÓS aqui, que foram colonizados pelos espanhol, e os que foram colonizados pelos portugueses, aqui no caso do Brasil, eles dizem aqui, houve o que foi uma invasão. Entendesse? O que na verdade NÓS SEMO intrusos aqui, NÓS QUE SEMO descendente tantos de portugues e espanhol, que os verdadeiros daqui foram invadidos, dominaram e terminaram com eles.

(LEO, homem, adulto, brasileiro, ensino médio)

\footnotetext{
102 A comunidade uruguaia de Aceguá é praticamente bilíngue, mas Isidoro Noblía é basicamente monolíngue em espanhol, o que dificulta a junção dos dados das duas comunidades como se fossem uma única.

${ }^{103}$ Exemplos: (i) E uma cosa que empecemo hoje; (ii) Nos aquí temo muitu contente; (iii) Trabalhemo uma semana. (Elizaincín, Behares, Barrios, 1987, p. 67).
} 
Aqui, tipo, NÓS QUE TRABALHEMO, QUE SEMO uruguaio e que TRABALHEMO no Brasil não TEMO carteira assinada, essas coisas.

(FLO, mulher, 15 a 30 anos, uruguaia, ensino médio)

Como exemplo de -emo no tempo pretérito no português brasileiro e uruguaio, temos:

E Punta del Leste fica junto. Quando NÓS ANDEMO lá, tu não sabe quando tá em Maldonado e...

(LEO, homem, adulto, brasileiro, ensino médio)

Sim, como nós. NÓS VIAJEMO uma vez, ano retrasado, a quatrocentos e pico quilômetros daqui, e falando assim, pensando que nós era um deles e coisa..

(JEF, homem, 15 a 30 anos, uruguaio, ensino médio)

Para Ilari e Basso (2006, p. 176), a variante subpadrão que distingue nós cantamo de nós cantemo consegue distinguir morfologicamente dois tempos do verbo (o presente e o pretérito perfeito), uma diferença importante que o português brasileiro culto não consegue marcar e que o português europeu marca por uma distinção de nasalidade.

Em paralelo com a concordância de número, tem-se a concordância de gênero associada ao pronome a gente. Hensey (1972, p. 71-75) defende que a concordância de gênero e de número no português popular é marcada apenas no primeiro elemento à esquerda do sintagma, diferentemente do espanhol do Uruguai. No entanto, por meio de pesquisa variacionista, Carvalho (2006) analisou a concordância nominal no espanhol da fronteira e encontrou o mesmo padrão que o português brasileiro.

Pacheco (2010, p. 134, 135) analisa a concordância de gênero em dados de Cuiabá e delimita os tipos de sintagmas nominais e predicativos e as posições dos elementos que favorecem a concordância. Segundo a autora,

\footnotetext{
os elementos à esquerda favorecem a concordância de gênero, em detrimento dos elementos à direita, quantificadores e predicativos. Portanto, a hipótese da posição à esquerda para a concordância de gênero é confirmada, principalmente com o artigo + nome, adjetivo + nome e possessivo + nome .
}

Dessa forma, não é qualquer primeiro elemento à esquerda que favorece a concordância de gênero, pois quantificadores e predicativos, independentemente de suas posições, desfavorecem bastante a concordância. Os elementos que mais concordam são artigo, adjetivo e possessivo antes do nome. 
Com relação à concordância de gênero, há apenas quatro dados em que é possível identificar uma marca de gênero nos sintagmas nominais (dois primeiros exemplos) e nos sintagmas predicativos (dois últimos exemplos), como a seguir:

Entrevistadora: Gostaram de Porto Alegre?

Entrevistadas: Sim. Bem legal lá. Totalmente diferente daqui. Claro, cidade, A GENTE ACOSTUMADA com cidadezinha.

(MAI, mulher, 15 a 30 anos, brasileira, ensino médio)

Mas vocês aqui não falam não?

Não, não. E se A GENTE vai lá eles falam português com A GENTE TRANQUILO.

(MAR, mulher, idosa, brasileira, ensino médio)

A senhora tem a dupla nacionalidade?

Tenho, e legal né. Porque no Uruguai, pela parte da mãe, A GENTE automaticamente É URUGUAIO. Nascida no Rio Grande do Sul, mas com todos os dereitos.

(MAR, mulher, idosa, brasileira, ensino médio)

Então há um monte de... mas não há na diferença cultural assim... e se há A GENTE não nota porque TÁ TÃO INTEGRADO.

(ALE, homem, acima de 50 anos, uruguaio, ensino médio)

No primeiro exemplo, a colaboradora utilizou a expressão "a gente acostumada" no feminino. Pelo contexto, o tipo de referência é mais específico, uma vez que a entrevista foi feita com duas jovens irmãs, o que corrobora o fato de elas terem se incluído enquanto mulheres. Nos demais exemplos, a referência é genérica e, por isso, a concordância de gênero também está no masculino genérico.

O caráter não marcado significa que as desinências de terceira pessoa ocorrem em diversos contextos linguísticos e que "aparecem quando não há nenhuma razão especial para que apareçam os de primeira pessoa. Por exemplo, a terceira pessoa ocorre com todos os SNs da língua, exceto os que incluam eu ou nós" (PERINI, 2008, p. 128). Martin (1975, p. 08) já falava também em gênero a partir do ponto de vista das formas marcadas e não-marcadas:

no lugar de "gênero", então, fica o conceito de adjetivos marcados ou não marcados. Os marcados correspondem aos "femininos" da gramática escolar, e aparecem somente quando o adjetivo está relacionado a um substantivo marcante. Os não marcados aparecem EM TODAS AS OUTRAS CIRCUNSTÂNCIAS, haja ou não um substantivo a eles relacionado. É este último fato que determina que o assunto não seja uma mera questiúncula terminológica, pois as conclusões dele decorrentes transformam dum modo essencial nossa maneira de encarar a categorização dos substantivos e o fenômeno da concordância adjetiva. 
Os elementos não marcados, neutros, genéricos, impessoais e indeterminados tendem a ser marcados no plural e/ou masculino. Por isso, a concordância no masculino dos três dados de a gente, em um total de quatro dados. Essa interpretação menos específica também favorece a presença de a gente em detrimento do pronome nós.

Assim, diante dos poucos dados de concordância de gênero, fica impossível submetê-los a qualquer análise quantitativa. Já os dados de concordância de número não foram submetidos à análise estatística, porque o objetivo principal dessa seção é apenas ilustrar os possíveis tipos de concordância com os pronomes explícitos nós e a gente e os sujeitos implícitos em uma comunidade fronteiriça. Em futuros trabalhos, seria interessante transformar essa codificação em variável dependente para analisar o fenômeno da concordância de número com a primeira pessoa do plural em regiões fronteiriças e bilíngues.

Em suma, a respeito dessas primeiras reflexões sobre a configuração da concordância em Aceguá, ressaltam-se duas informações importantes: a identidade cultural e linguística de base rural com o exemplo de nós cantemo; e a alta marcação de concordância de número na fronteira. Percebe-se novamente o continuum entre o mais rural (nós cantemo) e o mais urbano (alta concordância) na fronteira.

Esses dados permitem observar que o traço de ruralidade no uso de (nós) cantemo é mais frequente no português uruguaio (38 dados) do que no português brasileiro da fronteira (18 dados). Essa forma linguística é recorrente em outras localidades rurais do Brasil, mas a diferença está relacionada ao tempo verbal. No português brasileiro de forma geral, o falante utiliza nós cantamo(s) para o presente e nós cantemo(s) para o passado, o que significa dizer que há uma especialização temporal. No caso da fronteira, há o uso dessa estrutura linguística com ambos os tempos verbais, ainda que os $82,2 \%$ (46 dados) estejam realmente no tempo presente ao invés dos 17,8\% (10 dados) no tempo passado.

De 1002 dados, 49 dados são de nós associado à forma verbal no singular (nós canta ou nós cantava). O restante dos dados está distribuído entre as formas do plural com nós, incluindo outros tipos de morfema (cantamo, cantamos, cantemo, cantemos,) O pronome a gente aparece sempre concordando com a terceira pessoa do singular ( $a$ gente canta), ou seja, não há dados de a gente cantamo(s). Isso evidencia também uma alta concordância no português uruguaio e no português brasileiro de Aceguá, talvez também por uma influência do contato linguístico da fronteira, porque no espanhol só existe a forma nosotro $(s)$ cantamo $(s)$, não havendo o registro de *nosotro $(s)$ canta. 
A variação pronominal, portanto, se dá apenas no singular, que pode ser preenchido por nós ou a gente. Ainda assim, a gente canta, em detrimento de nós canta, predomina na análise uruguaia, com $75 \%$ dos dados, e também na análise brasileira, com $68,6 \%$ dos dados.

Dessa forma, a distribuição percentual da concordância de número associada à alternância pronominal de primeira pessoa do plural amplia a visão do encaixamento linguístico em situações de contato linguístico e com variedades minoritárias.

Para dar seguimento às interpretações e análises feitas acerca da variação pronominal de primeira pessoa do plural, seguimos para o próximo capítulo sobre as identidades múltiplas que os falantes da fronteira possuem e suas relações sociais com os pronomes nós e a gente do lado brasileiro e do lado uruguaio. Essa análise é de cunho qualitativo e busca complementar os resultados quantitativos a fim de entender mais e melhor o fenômeno em questão. 


\title{
CAPÍTULO 6 - IDENTIDADE SOCIOLINGUÍSTICA NA FRONTEIRA DE ACEGUÁ (BRASIL-URUGUAI)
}

\begin{abstract}
A identidade dá-nos a ideia de quem somos e de como nos relacionamos com os demais e com o mundo em que vivemos. Ela marca as formas em que somos iguais aos outros que compartilham dessa posição, bem como as formas em que somos diferentes daqueles que não compartilham da nossa posição. Frequentemente, a identidade é mais claramente definida pela diferença, isto é, por aquilo que não é. Identidades podem estar marcadas pela polarização, por exemplo, nas maneiras mais extremas de conflito nacional ou étnico, pela marca de inclusão ou exclusão - estrangeiros e nativos, "nós" e "eles". As identidades frequentemente são construídas na forma de oposições tais como homem/mulher, negro/branco, hétero/gay, saudável/não saudável, normal/anormal.
\end{abstract}

(WOODWARD, 1997, p. 1-2) ${ }^{104}$

Labov (1972a) define a comunidade linguística como um grupo de falantes que compartilham o mesmo sistema linguístico e um conjunto de normas sociais. Para a comunidade fronteiriça de Aceguá, como seria a delimitação dessa norma? No caso dos uruguaios, trata-se, em sua grande maioria, de duas normas linguísticas (espanhol e português) e no caso dos brasileiros trata-se, em sua grande maioria, de uma única norma (português). No entanto, em termos sociais e identitários, as normas são frequentemente compartilhadas na comunidade de fala da fronteira de Aceguá.

Assim, segundo Scherre (2006, p. 718), o aspecto social (estratificação, estilo e avaliações subjetivas), na perspectiva laboviana, é um dos elementos de natureza externa à estrutura que ajuda a compreender a variação e a mudança linguística. $\mathrm{O}$ sentimento de pertencimento a uma ou outra comunidade de fala varia conforme a perspectiva dos próprios falantes.

Em observações participantes, nota-se que os brasileiros da fronteira sentem-se geralmente como pertencentes a uma só comunidade de fala brasileira, mas os uruguaios da fronteira geralmente se sentem pertencentes à comunidade de fala

\footnotetext{
104 "Identity gives us an Idea of who we are and of how we relate to others and to the world in which we live. Identity marks the ways in which we are the same as other who share that position, and the ways in which we are different from those who do not. Often, identity is most clearly defined by difference, that is by what it is not. Identities may be marked by polarization, for example in the most extreme forms of national or ethnic conflict, and by the marking of inclusion or exclusion - insiders and outsiders, 'us' and 'them'. Identities are frequently constructed in terms of oppositions such as man/woman, black/white, straight/gay, healthy/unhealthy, normal/deviant" (WOODWARD, 1997, p. 1-2).
} 
brasileira e uruguaia, ora com tendência maior para a comunidade brasileira ora para a uruguaia, como o caso dos jovens uruguaios colaboradores desta pesquisa.

É perceptível que ambos os lados da fronteira compartilham uma norma linguística, o português, e, portanto, constituem uma comunidade linguística definida pelos sujeitos de "mesmo" discurso identitário quando estão falando em português ou quando tentam se aproximar do português brasileiro utilizando o pronome $a$ gente.

Com relação à variação pronominal de primeira pessoa do plural, os resultados linguísticos e sociais são semelhantes, o que confirma que a comunidade de Aceguá partilha normas linguísticas e sociais da fronteira. Do ponto de vista social, os jovens uruguaios favorecem o pronome a gente apenas com a retirada dos dados categóricos de nós. Por isso, é de suma importância investigar que tipo de relação identitária se manifesta na comunidade, de ambos os lados da fronteira, e no próprio indivíduo.

$\mathrm{Na}$ análise com todos os dados, os uruguaios alcançam $29,3 \%$ no uso de $a$ gente e os brasileiros, $58,6 \%$. $\mathrm{Na}$ análise sem os dados categóricos em nós, há um aumento significativo para os uruguaios $(49,1 \%)$ e para os brasileiros $(63,4 \%)$. Essa diferença percentual entre as análises, por conta da manifestação linguística individual, é também uma motivação para analisar a identidade dos colaboradores da fronteira de Aceguá, sobretudo, dos uruguaios que fazem parte dos 29,3\%. Assim, é possível entender melhor porque alguns colabodores uruguaios usam categoricamente o nós.

Labov (1972a e 1972b) já tratava da questão da identidade no caso de Martha’s Vinneyard, em que situa bem o que é aceito localmente e o que é visto como de fora da ilha; a segregação em guetos dos adolescentes afro-americanos em Nova Iorque a partir do apartheid social; e etnias judaicas e ítalo-americanas em Nova Iorque que entram em contato com a língua dominante.

Sobre Martha's Vinneyard, Labov (2008, p. 48, 52, 59) identificou que os que planejavam ficar na ilha exibiam maior centralização no uso dos ditongos (ay) e (aw) do que os que planejavam deixar a ilha. Inclusive o grupo dos portugueses que se identificavam mais com a ilha também exibiam maior centralização do que os descendentes de ingleses, já que os portugueses afirmavam seu status de vineyardenses nativos com a realização de um traço linguístico também específico da comunidade de Martha's Vineyard, demonstrando uma atitude positiva para com a ilha.

Dessa forma, há semelhança entre Martha's Vineyard e Aceguá no tocante à constituição urbana e rural de ambas as comunidades, bem como na motivação para o uso ou não da variante inovadora. Os falantes uruguaios que usam categoricamente nós 
têm redes sociais mais restritas ao Uruguai, sem muito contato com o Brasil e demonstram uma identidade mais uruguaia, com poucos elementos brasileiros. É parecido com os falantes nativos da ilha de Martha's Vineyard que demarcam sua identidade cultural com a alta centralização dos ditongos, com um sentimento de pertencimento à ilha.

Já a presença do pronome a gente pode estar associada à aproximação do modo de falar e viver tipicamente brasileiro, mesmo que de forma inconsciente, contrariamente ao que acontece em Martha's Vineyard, já que a alta centralização dos ditongos (ay) e (aw) estava relacionada à grande resistência às incursões dos veranistas, ou seja, com os que vêm de fora.

Logo, em Aceguá o pronome a gente não parece ser interpretado como um padrão vindo de fora que precise ser combatido. Pela própria identificação com o Brasil e com o fato de muitos também serem brasileiros, essa reação é menos segregadora. Para Labov (2008, p. 43), "somente quando se atribui significado social a tais variações é que elas são imitadas e começam a desempenhar um papel na língua. A regularidade, portanto, vai ser encontrada no final do processo".

E no caso da fronteira, será que a identidade é mais brasileira, mais uruguaia ou são híbridas e fluidas? Como a identidade sociolinguística é formada e constituída na fronteira e de que forma ela interfere no falar local e na escolha dos pronomes de primeira pessoa do plural? Todos esses questionamentos se intensificam depois dos resultados estatísticos que apontam que o sistema linguístico e social é, em grande parte, semelhante na comunidade de Aceguá como um todo, em ambos os lados da fronteira. Assim, é importante analisar também as questões mais subjetivas para tentar entender mais e melhor as múltiplas identidades que se manifestam no momento da interação entre os falantes da fronteira.

Para tentar responder a essas perguntas, é preciso entender como o bilinguismo, a territorialidade, a ecolinguística local, a nacionalidade, o processo de urbanização, a identidade, a alteridade, a pós-modernidade, os discursos identitários e os significados sociais das variantes se manifestam na fronteira. É o que se pretende fazer nas próximas seções com base nos autores Lash (1997), Woodward (1997), Lévy (1999) Moita Lopes \& Bastos (2002), Bauman (2001), Guiddens (2002), Dealtry (2002), Haesbaert (2002), Trindade (2002), Olinto (2002), Coracini (2003), Uyeno (2003), Leray (2003), Scherer, Morales e Leclerq (2003), Pagotto (2004), Hall (2005), Couto (2007, 2009) e Ivo (2013). 


\subsection{As identidades, os territórios e a Ecolinguística}

Do ponto de vista do bilinguismo, admite-se que os uruguaios utilizam como línguas maternas o português e o espanhol, já que dominam as duas igualmente, ainda que as utilizem em contextos sociais diferentes. "Língua materna é a que se domina mais e é normalmente falada em casa, tem a ver com a terra onde nasceu, a herança sanguínea e a língua na qual é criado" (UYENO, 2003, p. 40-41). No entanto, não se trata de apenas conviver com as duas línguas, mas de necessariamente utilizá-las na prática interativa e comunicativa.

Do ponto de vista ecológico, segundo a teoria da Ecolinguística (COUTO, 2007 e 2009), a língua é analisada juntamente com o meio ambiente. De acordo com o autor, “para que haja uma língua (L) é necessário haver um povo ou população (P) que a forme e use, sendo que esse povo tem que viver e conviver em determinado lugar ou território (T)". Essa totalidade é conhecida como comunidade (COUTO, 2009, p. 19).

Para Couto (2009), um dos tipos de contato linguístico seria a situação fronteiriça vista como o reflexo de dois povos e dois territórios. No caso de Aceguá, o lado uruguaio utiliza predominantemente o português, ainda que alterne com o espanhol, e o lado brasileiro utiliza o português. "Quando uma língua tem mais prestígio, tende a ser mais usada nas interações interlinguísticas.” (COUTO, 2009, p. 54). Como nessa fronteira não há nenhum acidente geográfico, "o mais comum é haver algum tipo de convergência linguística" (COUTO, 2009, p. 54). Essa convergência não é nenhuma espécie de "portunhol", mas a predominância do português da região em ambos os lados da fronteira ou de formas linguísticas típicas do português brasileiro.

No caso do Brasil-Uruguai, os conquistadores desse território foram os portugueses e espanhóis. Com a dizimação das línguas indígenas, passa a prevalecer o português em ambos os lados da fronteira independentemente da divisão política dos territórios. Quando há conquistas e a dominação de povos, frequentemente os detentores do poder delimitam artificialmente determinado território como sendo do Estado, o que inclui o povo e a língua, ignorando os minoritários ou mais fracos (COUTO, 2009, p. 113-114).

No início do processo de territorialização com povos e línguas diferentes, concebe-se uma sociedade, bilíngue ou multilíngue, e depois tenta-se a todo custo transformá-los numa única nação, com uma única língua e com uma única identidade. 
A delimitação de uma região multilíngue traz implicações políticas, culturais e educacionais, como políticas e planejamentos linguísticos centralizadores que privilegiam a língua estatal, discursos oficiais, publicações e meios de comunicação de massa. A língua estatal não significa língua da nação ou do povo como um todo, porque cada povo é uma nação, por mais que se queira ter uma nação ideal, homogênea e, sobretudo, artificial (COUTO, 2009, p. 130).

A verdade é que o sentido de nação é uma construção imaginária efêmera e errônea por projetar uma história e uma cultura homogêneas (DEALTRY, 2002) na relação direta entre identidade nacional e comunidade imaginada (WOODWARD, 1997, p. 18). A língua oficial ou estatal também é, de certa forma, uma língua imaginada, porque não existe enquanto manifestação linguística real.

A fronteira é um excelente exemplo de uma situação linguística altamente heterogênea. Por conta de todos os fatores intrínsecos à situação fronteiriça, bilíngue e de múltiplas identidades, devemos considerá-la ora como uma única comunidade de fala brasileira, a partir da convergência com o uso do português e com o uso do pronome $a$ gente na tentativa de aproximação com o português brasileiro, ora como duas comunidades de fala quando do lado uruguaio se utiliza o espanhol e do brasileiro o português. Do ponto de vista da nação, são duas nações, mas do ponto de vista linguístico e interacional ora os sujeitos se colocam como distintos, ora como pertencentes a uma mesma comunidade. Assim, partilham de normas sociais comuns aos dois lados da fronteira. Para Couto (2009, p. 14), a situação fronteiriça em Chui/Chuy é de

\footnotetext{
um único ecossistema, mesmo que transicional, entre dois outros ecossistemas maiores, ou seja, trata-se de uma única comunidade de fala. Um dos principais argumentos é o de que há uma comunidade entre os dois lados (só uma avenida separa Brasil e Uruguai); uma vista aérea nos revela uma única cidade. Um segundo argumento é a atitude dos membros da comunidade. Para eles é "uma coisa só". Quem mora de uma lado não considera o morador do outro lado da avenida como alguém de "outra" cidade.
}

Isso também acontece com Aceguá. A diferença principal das duas fronteiras é que em Chuy o espanhol é a língua predominante e em Aceguá é o português, o que nos leva a entender, do ponto de vista linguístico e identitário, que ora a comunidade uruguaia interage em português, ora em espanhol, enquanto a brasileira predominantemente em português. Essa alternância entre as línguas pode ser 
consequência de aproximações identitárias múltiplas que acontecem na fronteira, dependendo do interlocutor, do grau de intimidade, do assunto da conversa, da proximidade com as línguas ou os países.

Com relação aos resultados linguísticos e sociais, de maneira geral, a comunidade se manifesta de forma mais convergente. Interessante retomar a diferença que houve com os resultados sociais com e sem os falantes categóricos no pronome nós. $\mathrm{Na}$ análise brasileira, tanto com ou sem os falantes categóricos, o padrão da faixa etária foi o mesmo com os jovens favorecendo a gente. Já na análise uruguaia com todos os colaboradores, os adultos favoreciam a gente e os jovens e os de mais idade favoreciam nós. Ao analisar cada falante isoladamente, percebeu-se que parte desses jovens apresentou um uso categórico de nós porque não tinham contato com o Brasil, eram mais voltados para o Uruguai e, portanto, tinham menos mobilidade social e geográfica que os demais. Retirando esses casos categóricos, o padrão da faixa etária se manifesta igualmente à análise brasileira, mostrando a força do condicionamento social semelhante na fronteira.

O padrão etário resultado da análise com todos os falantes, com adultos favorecendo a gente, e da análise sem os casos categóricos, com jovens favorecendo $a$ gente, também mostra como as comunidades de fala são permeadas pelas identidades múltiplas dos grupos e dos indíviduos.

A tendência ao polo brasileiro acontece, diacronicamente, devido à influência histórica dos portugueses na região e, sincronicamente, devido à presença massiva do português monolíngue como língua dominante, mais urbana, de maior prestígio econômico, social, político e comercial. Assim, a fronteira política não coincide com a fronteira linguística, porque aquela é artificial e esta, natural. O que é natural certamente varia e muda ao longo do tempo, diferentemente do estático e convencionado.

Qualquer comunidade existe em um tempo materializado em um espaço. Assim, é também importante analisar a fronteira a partir da geografia, como de certa forma trabalha a Ecolinguística. Para Haesbaert (2002, p. 31), o tempo e o espaço geográfico não estão desaparecendo, mas surgindo sob novas formas e novos significados. Essa ideia é reforçada por Bauman (2001, p. 15) para quem "a modernidade começa quando o espaço e o tempo são separados da prática da vida e entre si", uma vez que antigamente eram estáveis e se correspondiam biunivocamente.

Para definir território, segundo Haesbaert (2002, p. 35), há três linhas de pensamento: a primeira vê o território do ponto de vista econômico como "base 
material, concreta, de reprodução da sociedade”. A sociedade, assim, será mais territorializada quanto mais for dependente das bases materiais como as sociedades indígenas. E quanto maior a tecnologia, maior a desterritorialização, que seria o fim das distâncias geográficas e o desapego do meio físico com o ciberespaço (Lévy, 1999). A ordem econômica da globalização também faz parte dessa interpretação, uma vez que a mobilidade espacial é maior e as grandes empresas se sobrepõem aos comércios locais (HAESBAERT, 2002, p. 36).

A segunda linha vê o território do ponto de vista político, do poder das instituições como forma de controle dos indivíduos. "Mas aqui também são muitos os que defendem a tese da desterritorialização: a globalização, suprimindo cada vez mais as fronteiras, estaria enfraquecendo o controle do Estado-nação, território por excelência da modernidade" (HAESBAERT, 2002, p. 37).

A terceira abordagem é o território a partir da dimensão cultural, dotado de identidade territorial (étnica, nacional, religiosa, dos grupos sociais). Mesmo assim, a cultura não pode ser vista independentemente da concepção política, "porque a produção simbólica que domina o nosso tempo é indissociável das relações de poder às quais está ligada. Assim, mesmo os geógrafos que destacaram a tradição política do território não ignoram suas bases culturais, simbólicas" (HAESBAERT, 2002, p. 37). É na perspectiva de cultura política, ao mesmo tempo material e simbólica, que Haesbaert lida com os processos de desterritorialização.

Hoje, na desordem territorial denominada precariamente de pós-moderna, lado a lado com uma globalização que se diz homogeneizadora e niveladora de culturas, surge uma fragmentação envolvendo territórios estataisnacionais, com um caráter político mais pronunciado, e territórios de forte conotação identitária" (HAESBAERT, 2002, p. 39).

Essa desterritorialização pressupõe necessariamente uma reterritorialização (reconstrução territorial), uma vez que a ecolinguística já resguarda a tríade "povo, língua e território" (COUTO, 2007, 2009) a partir das formas de organização. Há, portanto, um distanciamento ou alongamento do espaço-temporal, no qual o local se alonga ou desencaixa para atingir o global (HAESBAERT, 2002, p. 33). Esse global, em Aceguá, é a aproximação cada vez maior do Brasil e do português. Segundo Haesbaert (2002, p. 41), 
teríamos territórios culturalmente mais fechados, cujos grupos poderiam ser vistos, ao mesmo tempo, como territorializados (internamente) e desterritorializantes (na relação com grupos de outros territórios, deles excluídos), e territórios culturalmente mais híbridos, no sentido de permitirem/facilitarem o diálogo intercultural, quem sabe até possibilitando a emergência de novas formas, múltiplas, de identificação social.

Em Aceguá, ora a comunidade é mais territorializada como, por exemplo, no comportamento categórico de alguns jovens uruguaios no uso apenas de nós como pronome de primeira pessoa do plural, também pela pouca proximidade com o Brasil, ora desterritorializado, quando não se percebem diferenças sociais nas análises sem os casos categóricos, mantendo o padrão etário jovem como favorecedor do pronome $a$ gente. A autenticidade cultural tradicionalmente correspondia a um território de fronteiras bem definidas. Hoje, a identidade é híbrida e inautêntica (HAESBAERT, 2002, p. 46). Isso quer dizer que não há nada homogêneo quando se trata de fronteiras, cultura, identidade.

As territorializações são "efetivamente múltiplas, resultantes da sobreposição de funções e controles, como nas novas formas de gestão multiescalares em que começam a se conjugar níveis locais, regionais, nacionais, megarregionais (ou de blocos) e globais" (HAESBAERT, 2002, p. 48). Assim, um único indivíduo é capaz de vivenciar (dependendo da classe social e do contato com o Brasil) diversas territorialidades, assim como diversas identidades, mesmo estando em um único local físico que é dividido apenas politicamente. Essa territorialidade é simbolicamente vivida, não necessariamente concreta, física.

Um território múltiplo, onde devemos implementar não uma identidade una e pouco permeável ou, ao contrário, a diluição de todas as identidades, mas o convívio entre várias construções identitárias, inclusive aquela que envolve a opção de compartilhar múltiplos territórios. (HAESBAERT, 2002, p. 49).

O território múltiplo é associado à questão da nacionalidade, da identidade múltipla e do bilinguismo. Por isso, o português é visto politicamente no Brasil como língua nacional, e a defesa da unidade da língua como unidade nacional depende da instrução e da escolarização para a nacionalização do ensino e, consequentemente, da língua no estado do Rio Grande do Sul (TRINDADE, 2002, p. 238-239).

Todas essas estratégias governamentais evidenciam que a nação brasileira era constituída de culturas diversas, havendo inclusive o controle governamental do número de casamentos e de filhos entre brasileiros e entre brasileiros e outras nacionalidades, e que o processo de unificá-la envolveu conquista violenta, pois ocasionou, por vezes, a supressão forçada das diferenças 
culturais e sua tradução pela mescla de identidades, com os governantes intervindo nas escolas - fechando-as e demitindo professores (as) - e obrigando o uso de uma única língua. Pode-se constatar, ainda, como se dava essa imposição, examinando-se o jogo de forças - ser brasileiro(a) ou ser estrangeiro(a): falar a língua de origem ou falar a língua nacional - em que se defrontam internamente pessoas e grupos, com suas diversidades étnicas. (TRINDADE, 2002, p.241).

Já no Uruguai, a língua espanhola é fator identitário do uruguaio, ainda que nessa última década as políticas bilíngues estejam mais em voga, ou seja, se o uruguaio fala português, sua identidade é enfraquecida por esse discurso nacional de que no Uruguai se fala espanhol e que ser uruguaio pressupõe a fala espanhola (CARVALHO, 2006). Nessa situação, como fica a identidade do fronteiriço, sobretudo do uruguaio bilíngue? Há alguma relação direta entre identidade, nacionalidade e uso linguístico?

\subsection{As identidades e as nacionalidades}

A língua materna é falada primeiramente no espaço familiar. Assim, ao estabelecer uma língua oficial, o Estado ignora a língua das minorias e não prevê as diferenças linguísticas e sociais em todo o território brasileiro.

A identidade nacional representa uma cultura nacional, apenas como construção discursiva. "Vistas como discursos, as culturas nacionais correspondem a modos de construir sentidos, que influenciam e organizam tanto nossas ações quanto a concepção que temos de nós mesmos." (TRINDADE, 2002, p.247).

As culturas nacionais não deixam, portanto, de contribuir para a construção das nossas identidades, mas também não têm relação direta e única, porque, inclusive, alguns colaboradores de Aceguá diziam que eram brasileiros e depois, no meio da entrevista, diziam que eram uruguaios também e vice-versa. Ou seja, muitas vezes eles tinham as duas nacionalidades, mas se identificavam primeiro com apenas uma, e depois se lembravam de que também tinha outra.

A identidade cultural como identidade nacional também é fragmentada na modernidade tardia, por isso, é difícil para os fronteiriços definirem, muitas vezes, se são uruguaios ou brasileiros. "As identidades nacionais não são coisas com as quais nós nascemos, mas são formadas e transformadas no interior da representação" (HALL, 2005, p. 48). Como exemplo disso, temos dois falantes: uma jovem uruguaia (também com nacionalidade brasileira), filha de mãe uruguaia e pai brasileiro; e um jovem 
brasileiro, filho de pais brasileiros. A menina, não consegue se enquadrar em apenas uma nacionalidade:

Entrevistadora: Mas o primeiro registro foi em que?

Entrevistada: Brasileiro. Mas é como tudo, eu tenho a documentação uruguaia. O pessoal da fronteira é enrolado, o pessoal da fronteira tem os dois documentos, entende? Então eu não tenho como dizer eu sou só brasileira. Eu sou brasileira e sou uruguaia ao mesmo tempo.

Entrevistadora: Se bem que ficar como brasileiro... por exemplo, quando eu te pergunto tu te identifica primeiro como uruguaia ou como brasileira assim? Entrevistada: Como brasileira.

Entrevistadora: Como brasileira?

Entrevistada: Como brasileira, sim. Por isso que eu te digo que eu tenho dois documentos, e toda vida estudei no Uruguai, e se eu tivesse que abrir mão de um documento, pra mim seria difícil. Por quê? Porque eu sou brasileira. E dizia: mas não, eu sou brasileira, nasci no Brasil, sou brasileira, quero o Brasil, e eu sou brasileira. Mas os meus estudos, a minha carreira, tudo o que eu fiz, tá tudo no Uruguai, eu não posso abrir mão do Uruguai. Mas a mim me doi se eu tenho que abrir mão do Brasil, entende?

(CAR, mulher, de 15 a 30 anos, uruguaia, ensino médio)

Assim, a entrevistada diz que é brasileira e uruguaia ao mesmo tempo, porque tem necessidade de legitimação do estado, mas afirma que se identifica mais com o Brasil porque nasceu lá, ainda que não consiga abrir mão do Uruguai, onde se dedicou aos estudos e à carreira. Suas identidades são múltiplas ou, no caso dessa fronteira, duplas, fragmentadas e também construídas no momento da interação quando fala que sente "dor" de ter de abrir mão de alguma nacionalidade.

No caso do jovem brasileiro, ele já não se identifica muito com os costumes da fronteira e manifesta gostos mais gerais, globalizados, externos à comunidade, como o gosto por pagode.

Entrevistadora: Pois é, seria ótimo. Aí, o que você conseguir, prA GENTE vai se bom. Vocês vão participar dos festejos aí da Semana Farroupilha?

Entrevistado: É, frequento. Não é muito o meu...

Entrevistadora: É? Não se identifica muito não?

Entrevistado: Não é muito meu gosto. É, não.

Entrevistadora: É mesmo? Achei que era super...

Entrevistado: Apesar de ser daqui...

Entrevistadora: Eu achei que era geral.

Entrevistado: É. Mesmo sendo daqui, música gaúcha aí, no ritmo uruguaio que é a Cúmbia... não consigo gostar.

Entrevistadora: É mesmo?

Entrevistado: Sou mais pagodeiro.

Entrevistadora: Ah, é?

Entrevistado: Sou mais pagodeiro.

(GUI, homem, de 15 a 30 anos, brasileiro, ensino médio) 
Dessa forma, o jovem demonstra certa distância da Semana Farroupilha, uma festa típica do Sul do Brasil e já enraizada também na fronteira, compartilhada pela maioria dos uruguaios e brasileiros. Esse falante, independetemente da nacionalidade e do território onde mora, diverge em algumas normas sociais da comunidade, ou seja, não há sentimento de pertença ao grupo cultural brasileiro.

A nação, além de uma entidade política, é um sistema de representação cultural. “As pessoas não são apenas cidadãos/ãs legais de uma nação; elas participam da ideia de uma nação tal como representada em sua cultura nacional" (HALL, 2005, p. 49). As identidades nacionais também já foram mais unificadas, mas agora estão sendo deslocadas por causa dos processos de globalização (HALL, 2005, p. 50).

Para Hall (2005, p. 52-55, 58), há que se levar em consideração as estratégias discursivas para a construção de uma comunidade imaginada: memórias do passado, o desejo por viver em conjunto e a perpetuação da herança nacional. A cultura nacional é também um discurso, porque é o modo de construir e dar sentido às nossas ações e ao que somos nós. Ao produzir sentido sobre a "nação", constroem-se identidades que podem identificar os sujeitos ou não (HALL, 2005, p. 50-51). A identidade nacional é baseada na ideia de um único povo, mesmo que nem todos participem da mesma forma na sociedade, uma vez que as nações modernas são híbridos culturais (HALL, 2005, p. $55 ; 62)$.

Em Aceguá, a nacionalidade e a identidade sociolinguística estão imbricadas, o que impede qualquer tentativa de separação rígida entre os dois países, ou seja, não basta oficialmente ser uruguaio ou ser brasileiro para haver correspondência direta com a cultura, a identidade e a língua desse país. Muito pelo contrário, pois as relações identitárias na fronteira perpassam a simples nacionalidade, sobretudo do lado uruguaio, uma vez que são bilíngues e as relações bem heterogêneas. Por isso, fizemos três análises, uma da comunidade como um todo, uma do lado uruguaio e outra do lado brasileiro, interpretando ora a identidade cultural geral, ora fragmentada em uruguaio ou brasileiro.

\subsection{As identidades e as diferenças}

"É questionável a homogeneização como fundamento de uma identidade "autêntica", tanto em termos individuais como comunitários, tanto como a ideia de nação, ou nacionalidade, como um fato, um dado real" (UYENO, 2003, p. 40-41). Os 
processos identitários são mais flexíveis e híbridos e a heterogeneidade faz parte da vivência social. A materialização da identidade se dá a partir do momento em que se conhece o outro, ou seja, é na diferença de um sujeito para o outro que se constrói(em) a(s) identidade(s).

Para Olinto (2002, p. 261), a dissolução do sujeito e o abandono de mitos fundadores contribuem para novas formas de emancipação. O modelo político da diferença questiona o universalismo abstrato da natureza humana (individuum = indiviso) e entende a realidade social "como sistema diferencial composto por uma multiplicidade de discursos que, por seu lado, produz uma multiplicidade de posições para o sujeito, marcando o caráter processual de identidades nunca finalizadas".

A identidade e a linguagem refletem um "discurso inconsciente que nos habita e que é constituído por um eu a partir de um outro numa alteridade sem limites" (SCHERER, MORALES e LECLERQ, 2003, p. 24) e que significa intervalos da vida do sujeito e de sua história. O sujeito se reconhece e é reconhecido por sua alteridade. "A diferença é crucial para classificar sistemas através dos quais significados são produzidos" $" 105$ (WOODWARD, 1997, p. 47). Assim,

\begin{abstract}
esse sujeito não pode dispor de seu deserto sem uma história e é sua história (individual e coletiva) que vai ajudá-lo, vai dar-lhe os meios de povoá-lo, de dispô-lo, de fazê-lo prosperar, de eliminar, preservando sua identidade porque sabemos que todo sujeito é único e singular em seu tempo e em seu espaço. Seu percurso está ligado à sua história de vida e vice-versa. (SCHERER, MORALES e LECLERQ, 2003, p. 24).
\end{abstract}

"A identidade do "forasteiro" é produzida em relação com "pessoa de dentro"106 (WOODWARD, 1997, p. 33). Assim, a ideia de um "eu" isolado no mundo é uma ilusão, porque certamente está enraizado em algum grupo social que compõe uma comunidade (LERAY, 2003, p. 119). “A língua é o primeiro vetor identitário que testemunha a diversidade sociolinguística das comunidades humanas e a construção identitária não se restringe aos limites de um território, mas inscreve-se numa história mestiça de línguas e de culturas" (LERAY, 2003, p. 120).

Nesse trabalho, a identidade, construída e identificada social e culturalmente na alteridade com o outro, é entendida na sua pluralidade, multiplicidade e diversidade de papéis e práticas sociais, transformações, contextos, discursos, textos.

\footnotetext{
${ }^{105}$ Difference is central to classificatory systems through which meanings are produced (WOODWARD, 1997, p. 47).

${ }^{106}$ The identity of the 'outsider' is produced in relation to the 'insider (WOODWARD, 1997, p. 33).
} 
A identidade, então, não é o oposto da diferença, mas depende dela. Nas relações sociais, essas formas de diferença social e simbólica são estabelecidas, pelo menos parcialmente, por meio da operação dos que são conhecidos como sistemas classificatórios. Um sistema classificatório aplica o princípio da diferença a uma população de tal forma que possa dividi-la e todas as suas características em, pelo menos, dois grupos opostos - nós / eles; eu / o outro (tradução nossa) (WOODWARD, 1997, p. 29) ${ }^{107}$.

O sujeito pós-moderno possui identidades sociais individuais (pessoal) e comunitárias (coletiva) também decorrentes do processo de globalização, como pertencente a uma cultura local e global (LASH, 1997). Segundo Giddens (2002, p. 13), "quanto mais a tradição perde seu domínio, e quanto mais a vida diária é reconstituída em termos do jogo dialético entre o local e o global, tanto mais os indivíduos são forçados a escolher um estilo de vida a partir de uma diversidade de opções".

Posto isso, a identidade é fragmentada e definida culturalmente, pois assumimos identidades diferentes em situações diferentes (o ser da fronteira é diferente do ser da capital), em decorrência das novas exigências, mudanças sociais, transformações sociais, novas organizações sociais, novos estilos. Assim, entender a identidade também é compreender o processo de mudança da língua e da sociedade. Tudo isso tem a ver com língua enquanto sociedade multifacetada, variada, bilíngue conforme explica Ivo (2013, p. 104).

\begin{abstract}
Nesse processo cultural e na construção das suas significações, construímos e (re)construímos a nossa identidade sob a influência e à luz da experiência do mundo social, das suas relações, das suas desigualdades e dos diferentes grupos culturais com os quais convivemos.
\end{abstract}

Esse processo de ida e vinda, de construção e reconstrução, simboliza um período de crise de identidade provocado também pela ideologia da globalização que pretende centralizar e homogeneizar tudo e todos. "As diferenças só são respeitadas na medida em que elas garantem a manutenção ou a criação de um novo mercado de consumo" (CORACINI, 2003, p. 13). Ainda segundo a autora,

se buscássemos arrolar características, estaríamos estudando a identidade (do lat. idem $=$ mesmo) como o mesmo, idêntico a si, como consciência, razão e não como diferença, descontinuidade, fragmentação. No primeiro caso,

\footnotetext{
${ }^{107}$ Identity, then, is not the opposite of, but depends on, difference. In social relations, these forms of symbolic and social difference are established, at least in part, through the operation of what are called classificatory systems. A classificatory system applies a principle of difference to a population in such a way as to be able to divide them and all their characteristics into at least two, opposing groups - us/them; self/other (WOODWARD, 1997, p. 29).
} 
estaríamos situando nossas pesquisas numa perspectiva sociológica, que parece mais preocupada em definir a identidade de grupos - nacional, étnica, cultural, sexual, de gênero, profissional... Entretanto, se buscarmos compreender o sujeito como dispersão, sujeito cindido, dividido, atravessado pelo inconsciente, estaremos adotando seja uma perspectiva filosófica (derridiana), seja uma perspectiva discursiva que encontra na psicanálise seu ponto de apoio, voltada sobretudo para a constituição do sujeito do inconsciente que, imerso no discurso - que sempre provém do outro -, é mais falado do que fala (Lacan) (CORACINI, 2003, p. 14-15).

A identidade na modernidade tardia ou pós-colonial também é reflexo de mudanças sociais, culturais, políticas, econômicas e tecnológicas que vivenciamos e que vem trazendo problemas quanto à nacionalidade e territorialidade. "Vivemos, desse modo, tempos em que há em curso um grande repensar sobre quem somos: os vários veículos da mídia (jornais, revistas, rádio, televisão, internet etc.) deixam clara tal tendência diariamente" (MOITA LOPES \& BASTOS, 2002, p. 14). E tudo isso é de fundamental importância para compreender o mundo em que vivemos.

A mudança identitária também perpassa pelas questões midiáticas. Em Aceguá, esse polo também é voltado para o Brasil, especialmente a TV Globo e as rádios brasileiras, que são bem presentes no cotidiano dos membros da comunidade fronteiriça. “A experiência canalizada pelos meios de comunicação, desde a primeira experiência da escrita, tem influenciado tanto a auto-identidade quanto a organização das relações sociais" (GIDDENS, 2002, p. 12).

\subsection{As identidades e a pós-modernidade}

Para Bauman (2001, p. 17-18), estamos em um período de transição da modernidade sólida para a líquida, dinâmica, com mais mobilidade. Os sólidos são estáveis e os líquidos fluidos:

\footnotetext{
Os sólidos que estão para ser lançados no cadinho e os que estão derretendo neste momento, o momento da modernidade fluida, são os elos que entrelaçam as escolhas individuais em projetos e ações coletivas - os padrões de comunicação e coordenação entre as políticas de vida conduzidas individualmente, de um lado, e as ações políticas de coletividades humanas, de outro (BAUMAN, 2001, p. 12).
}

Para Bauman (2001), a identidade é única, individual. Portanto, mudar de identidade significa romper com o passado, com determinados vínculos e certas obrigações. Viver em harmonia é utopia de qualquer comunidade, mas, no caso de 
Aceguá, em certa medida, isso se concretiza bem, porque há uma interação mútua entre ambos os lados da fronteira.

A mudança e a crise da identidade na sociedade pós-moderna declinaram as identidades anteriores, que por tanto tempo guiaram o mundo social. Agora surgem novas identidades que fragmentam o indivíduo moderno, antes visto como um sujeito unificado. A identidade está deslocada, fragmentada e descentrada em várias (HALL, 2005, p. 7).

Em uma mesma comunidade de fala, como é o caso de Aceguá, há variação no uso de nós e a gente e há categoricidade no uso de nós. E há uruguaios que se identificam como uruguaios e brasileiros, e há uruguaios que se identificam apenas como uruguaios. Do lado brasileiro, é mais comum a identidade ser apenas brasileira. Essas identidades não são unificadas ou únicas, mas, muitas vezes, partilhadas em duas, sobretudo para os uruguaios, porque também são os que falam mais as duas línguas, ou seja, ser bilíngue ou monolíngue na fronteira tem relação com a família, o lugar de origem, a(s) língua(s) que fala, além da nacionalidade propriamente dita.

Para Hall (2005, p. 10-13), há três concepções de identidade a partir de três épocas históricas, a saber:

- A identidade do sujeito do iluminismo - indivíduo centrado, unificado, racional. Concepção individualista, biológica, desde o nascimento até a morte.

- A identidade do sujeito sociológico - complexidade do mundo moderno. Concepção interativa da identidade e do "eu". Identidade cultural.

- A identidade do sujeito pós-moderno - múltiplas identidades. A identidade é histórica, e não biológica.

O mundo pós-moderno "é de muitas maneiras um mundo único, com um quadro de experiência unitário (por exemplo, em relação aos eixos básicos de tempo e espaço), mas ao mesmo tempo um mundo que cria novas formas de fragmentação e dispersão" (GIDDENS, 2002, p. 12). Assim, esse trabalho sobre a fronteira contempla, de certa forma, os sujeitos sociológicos e pós-modernos de Aceguá.

As sociedades modernas ou pós-modernas são, portanto, por definição, sociedades de mudança constante, rápida e permanente. "As sociedades da modernidade tardia [...] são caracterizadas pela "diferença"; elas são atravessadas por diferentes 
divisões e antagonismos sociais que produzem uma variedade de diferentes "posições de sujeito" - isto é, identidades - para os indivíduos (HALL, 2005, p. 17).

A pós-modernidade, modernidade radicalizada, alta modernidade ou modernidade alta e tardia de Giddens (2002) é de ordem pós-tradicional caracterizada por uma construção reflexiva do "eu”. As características da modernidade são, portanto, a reflexividade institucional, a reorganização do tempo e espaço e os mecanismos de desencaixe das relações sociais.

\begin{abstract}
A modernidade altera radicalmente a natureza da vida social cotidiana e afeta os aspectos mais pessoais de nossa existência. A modernidade deve ser entendida num nível institucional; mas as transformações introduzidas pelas instituições modernas se entrelaçam de maneira direta com a vida individual, e portanto com o eu. Uma das características distintivas da modernidade, de fato, é a crescente interconexão entre os dois "extremos" da extensão e da intencionalidade: influências globalizantes de um lado e disposições pessoais de outro. (GIDDENS, 2002, p. 9)
\end{abstract}

De acordo com Giddens, não basta agora também afirmar que o sujeito tem tantos "eus" a depender dos diferentes contextos de interação a que está exposto, já que não é correto "ver a diversidade contextual como simples e inevitavelmente promovendo a fragmentação do eu, quanto mais sua desintegração em "eus" múltiplos. Essa diversidade também pode, pelo menos em muitas circunstâncias, promover uma integração do eu" (GIDDENS, 2002, p. 176).

Nesse sentido, a modernidade também produz diferença, exclusão e marginalização, o que pode ocasionar a não realização do "eu", afastando a possibilidade da emancipação (GIDDENS, 2002, p. 13). Pode haver unificação proteção e reconstrução - ou fragmentação - abertura do mundo para o indivíduo (GIDDENS, 2002, p. 175).

Em Aceguá, não há acirramento suficiente entre os grupos sociais para um confronto nacional forte, mas os conflitos identitários existem em qualquer lugar. As questões históricas nos mostram certa coerência no quesito da integridade e interrelação entre os povos dessa região fronteiriça. No entanto, na maioria das vezes, "Na arena global, identidades nacionais são desafiadas, e lutas entre diferentes comunidades são representadas por identidades nacionais conflitantes - frequentemente com consequências desastrosas" (WOODWARD, 1997, p. 1) ${ }^{108}$.

\footnotetext{
${ }^{108}$ In the global arena, national identities are contested, and struggles between different communities are represented by conflicting national identities - often with disastrous consequences" (WOODWARD, 1997, p. 1).
} 
A representação cultural do que é ser da fronteira inclui também costumes considerados já brasileiros e uruguaios ao mesmo tempo, como a Semana Farroupilha, por exemplo, porque a identidade é negociada, construída, ratificada, retificada e refutada entre o coletivo e o individual. Por isso, ora a identificação é como uruguaio, e como falante de espanhol, ora como brasileiro, e como falante de português, ao mesmo tempo em que há uma tendência também para o mesmo uso do pronome a gente tanto no português uruguaio quanto no português brasileiro da fronteira. Essa tendência se dá até mesmo para que haja a ideia de inclusão de todos os fronteiriços em uma cultura maior, uma comunidade mais geral.

No entanto, socialmente é perceptível as nuances identitárias dos sujeitos, também manifestadas na escolha do pronome de primeira pessoa do plural. O "eu" uruguaio é associado ao nós, enquanto o "eu" brasileiro é associado à alternância entre nós e a gente. Posto isso, alguns "eus" mais arraigados ao Uruguai não utilizam o pronome a gente, e são categóricos no uso de nós.

Nos pronomes de primeira pessoa do plural, a gente é o mais inovador e, portanto, característico de centros mais urbanos. A comunidade de Aceguá é cerca de $80 \%$ da zona rural, mas os entrevistados são da área urbana, ainda que sofram influências rurais também. Para Pagotto (2004, p. 395),

se o processo de variação se inicia na zona urbana e já alcança a zona rural, não necessariamente haverá continuidade nessa direção, pois, uma vez instalado tal processo, a fala da zona rural, mesmo que 'intocada' e 'não afetada', já foi de fato afetada, passa a significar, porque está sob o guardachuva dos discursos de identidade.

Isso é característico da confluência de identidade por que passa os habitantes uruguaios e brasileiros de uma zona rural que adquirem traços linguísticos mais urbanos e típicos do português brasileiro. É como se, muitas vezes, os sujeitos buscassem, inconscientemente, identidades mais urbanas e próximas do ideal monolíngue brasileiro.

\subsection{As identidades discursivas e os significados sociais das variantes}

Pagotto (2004, p. 109) faz uma análise interessante entre a variação linguística como identidade discursiva no sentido de que "as formas variantes fazem falar vozes da comunidade, reunidas no interior da variável linguística”. Isso faz parte do sistema 
heterogêneo linguístico, social e simbólico, no qual as variantes adquirem significados sociais.

Em nosso entendimento, não se trata de uma análise anulando a outra, mas sim de serem complementares em busca dos reais significados das variantes dentro da comunidade linguística em questão, mesmo porque só é possível falar de identidade e fazer outras análises a partir dos resultados estatísticos que nos apontam para essa direção. Dessa forma, além da relação entre as variantes e as categorias sociais, também é possível discutir os significados sociais de tudo isso.

A geração mais nova, da comunidade de Aceguá como um todo, também é a que mais inova com o uso do pronome a gente, se os categóricos em nós da análise uruguaia são retirados, o que corrobora uma aproximação maior com a identidade brasileira. É como se a geração mais jovem estivesse "abrindo mão da cor local como traço fundamental de sua identidade e embarcando na aventura da modernidade" (PAGOTTO, 2004, p. 398).

Todavia o processo também não é generalizado para todos os jovens, tendo em vista que os uruguaios bilíngues mais afastados da zona fronteiriça e do contato com o Brasil são categóricos no uso de nós, confirmando as diversas formações da identidade. Essa análise só é possível ao olharmos para o indivíduo, no seu comportamento linguístico idioletal, que pode ou não ser reflexo do comportamento linguístico dialetal dos seus pares. Então, segundo Pagotto (2004, p. 399),

\begin{abstract}
A ponta extrema dessa observação são os falantes tomados sob lupa, individualmente. Sob esse último olhar, tanto vamos encontrar, como já vimos, falantes "bem comportados", isto é, refletindo o que se esperaria de sua posição na sociedade, quanto falantes "mal comportados", ou seja, expressando as formas variantes de uma maneira desviante em relação aos grupos aos quais estão rotulados. São estes últimos que nos levam a reafirmar que a entrada de uma forma variante na fala de um indivíduo se dá por uma interpelação de posições, que opera simbolicamente, não sendo, por conseguinte, uma decorrência imediata da vinculação deste ou daquele falante a um dado lugar na estrutura social, em função de sua história, sua escolaridade, sua idade, etc. Esta vinculação é, claro, um elemento importante, mas não é o central para explicar a distribuição das formas variantes.
\end{abstract}

O comportamento idioletal também é associado à manutenção de determinada identidade, ou seja, de uma identidade mais uruguaia, associada ao uso de nós. Analisando as variantes do pronome de primeira pessoa do plural, é possível interpretálas da seguinte maneira: 
i) O pronome a gente seria o pronome da inovação, da aproximação a tudo que é brasileiro, ao que é, de certa forma, estrangeiro, diferente, típico de uma variedade monolíngue. Esse pronome também pode ser interpretado como algo típico do processo de urbanização, modernização, pois representaria os novos tempos, a interrelação na fronteira, o polo econômico, social e político voltado para o Brasil.

ii) O pronome nós simbolizaria o pronome do conservadorismo tanto no espanhol uruguaio quanto no português brasileiro, mas, como não existe a gente pronominalizado no espanhol, para os bilíngues ou monolíngues uruguaios, a tendência seria preservar cada vez mais sua identidade uruguaia com o uso do pronome nós. É o oposto ao estrangeiro, mas, ao mesmo tempo, como também é um pronome utilizado no Brasil, reflete bem a questão da multiplicidade de identidade, porque o bilíngue uruguaio, muitas vezes, se considera brasileiro e uruguaio, representado por ambas as variantes. O nós simboliza também a questão da natividade, do nacionalismo e da identificação uruguaia.

Os uruguaios que não são bilíngues ou que não usam $a$ gente tendem a se distanciar do Brasil e da identidade brasileira. Já os brasileiros não se identificam como uruguaios em nenhum contexto e as variantes não são típicas do espanhol, uma vez que a gente é utilizado de maneira diferente enquanto, em ambas as línguas, os pronomes nós e nosotros desempenham função semelhante. A diferença, portanto, está exatamente no uso de a gente como terceira pessoa no espanhol e como primeira pessoa do plural no português.

O conceito de identidade é fundamental para o entendimento das mudanças sociais e culturais. No caso de Aceguá, a variabilidade que está em jogo nas variantes de primeira pessoa do plural se deve à mudança linguística com a inserção de a gente no português uruguaio, também instaurada no processo identitário local, e é motivada pelas mudanças sociais vigentes. A escolha de uma variante em detrimento da outra, nos mais variados contextos, está permeada das várias possibilidades da identidade se manifestar no sujeito. Segundo Pagotto (2004, p. 400),

o processo de espraiamento de determinada forma variante é identitário (e por conseguinte, simbólico) o que quer dizer que a relação entre um indivíduo e as categorias sociais a que está vinculado não é direta, isto é, não se trata de uma impressão digital, um carimbo ao qual estariam associados respectivos comportamentos linguísticos. 
O sujeito é multifacetado e, por isso, está imerso em diversas identidades a depender da variante escolhida, porque essa escolha é condicionada linguística e socialmente e os significados sociais são construídos de forma diferente a partir de cada variante em determinado contexto. A identidade é constitutiva do processo de variação e também da relação do sujeito brasileiro com a língua nacional, com a identidade da nação. As formas linguísticas variáveis refletem todo esse jogo discursivo (PAGOTTO, 2004, p. 134).

Com relação aos pronomes de primeira pessoa do plural, é interessante notar que, da mesma forma, só sabemos quem somos na interação com o outro, só sabemos o significado social que uma variante tem quando a confrontamos com outra. "É nisto que consistiria o significado social das variantes: posições de sujeito que se apropriam das formas variantes" (PAGOTTO, 2004, p. 124).

As variantes como portadoras de significação social são reflexos ideológicos e multifacetados das identidades multifacetadas dos falantes. A fala de uma pessoa, portanto, só é reconhecida a partir da existência da fala do outro e da interação entre ambas, o que pode ser ampliado para as variantes (PAGOTTO, 2004, p. 133).

O sujeito se utiliza do próprio sistema linguístico para nele inscrever suas marcas de identidade, fruto de ideologias, "que nos fazem "mesmos" e "diferentes", segundo a posição constituída: assim, ora se é brasileiro, ora se é de classe média, ora se é nativo, ora se é de fora" (PAGOTTO, 2004, p. 117).

“A identidade nos dá a localização no mundo e representa o vínculo entre nós e a sociedade em que vivemos"109 (WOODWARD, 1997, p. 1). O processo de identidade é algo constitutivo do próprio sujeito, por isso não está relacionado necessariamente à demarcação territorial política nem à nacionalidade. A representação da identidade inclui as práticas de significação e os sistemas simbólicos pensados como os sentidos são produzidos e como nos posicionam como sujeitos. A representação como processo cultural estabelece a identidade individual e coletiva, ou seja, diferentes sentidos, contestados e modificados, são produzidos por diferentes sistemas simbólicos.

Toda prática de significação que produz sentido envolve relações de poder, inclusive o poder que define quem é incluído ou excluído. Novas posições, novas identidades dependem também de mudanças econômicas, sociais e culturais a partir da

\footnotetext{
109 "Identity gives us a location in the world and presentes the link between us and the society in which we live" (WOODWARD, 1997, p. 1).
} 
globalização (WOODWARD, 1997, p. 14-16). Ainda assim, em Aceguá se mantém muito da cultura local da fronteira, mas é notório que a abertura para o mais global, mais urbano e mais brasileiro, também se manifesta no português uruguaio com a inserção de A GENTE, uma vez que o polo brasileiro e o ideal monolíngue são mais prestigiados. Ou seja, no caso da identidade, o pronome a gente entra na comunidade uruguaia como sujeito discursivo e não fere a identidade múltipla e fluida dos moradores da fronteira. 
Este trabalho analisou a alternância pronominal de nós e a gente no português brasileiro e no português uruguaio de Aceguá, cidade localizada na fronteira BrasilUruguai, e a identidade sociolinguística dos colaboradores dessa pesquisa.

A hipótese de que o pronome a gente estaria mais avançado no português brasileiro de Aceguá do que no português uruguaio de Aceguá foi confirmada na análise brasileira com todos os colaboradores $(58,6 \%)$ e ainda mais na análise brasileira sem os casos categóricos de nós $(63,4 \%)$ em detrimento da análise uruguaia com todos os colaboradores $(29,3 \%)$ e também na análise uruguaia sem os casos categóricos de nós $(49,1 \%)$. Esses resultados levam a acreditar na possibilidade de que a variação pronominal de primeira pessoa do plural seja inovadora no português uruguaio, visto que este seria um dialeto conservador, falado nos meios rurais e, em geral, mais distante das tendências normativistas ou urbanizadoras do Brasil.

Os resultados da pesquisa permitiram dar respostas às seguintes perguntas de investigação:

(i) O pronome a gente, amplamente utilizado no Brasil e na zona urbana, chega ao sul do país, mas atravessa a fronteira?

(ii) O pronome a gente está entrando no português uruguaio de Aceguá em qualquer função sintática?

(iii) A distribuição de nós e a gente nos dados do português uruguaio e do português brasileiro, ambos de Aceguá, se assemelha à distribuição de nós e a gente nas diversas regiões brasileiras, sobretudo na região Sul, onde se localiza Aceguá?

(iv) O grau de bilinguismo dos uruguaios interfere ou não no uso de $a$ gente?

(v) Que variáveis sociais e linguísticas condicionam a presença de a gente nas variedades de português faladas em Aceguá?

(vi) Que tipo de concordância verbal com os pronomes de primeira pessoa do plural, a gente e nós, existe no português uruguaio e no português brasileiro de Aceguá? 
(vii) A inserção do pronome a gente no português uruguaio é consequência do contato linguístico com o português ou é da própria natureza histórica e evolutiva do português uruguaio?

(viii) Como a identidade sociolinguística é formada e constituída na fronteira e de que forma ela interfere no falar local?

Assim, as respostas a essas peguntas nos levam a concluir que:

I. O pronome a gente, amplamente utilizado no Brasil e na zona urbana, chega ao Sul do país e atravessa a fronteira. Assim, essa categoria gramatical como primeira pessoa do plural passa a ser variável também no português uruguaio. Diacronicamente, no caso do português brasileiro, o seu uso como indefinido ou referência genérica entrou no lugar da expressão arcaica homen, enquanto no espanhol houve a inserção do termo uno ou una como indefinido. Sincronicamente, a expressão lexical plena a gente passou a equivaler a nós, tanto no português brasileiro quanto no português uruguaio, sendo utilizada como primeira pessoa do plural, independentemente de ter a referência genérica ou específica. Mesmo existindo, na língua espanhola, o correspondente nosotros para a primeira pessoa do plural, os bilíngues vêm utilizando o pronome $a$ gente, que é totalmente diferente do uso de la gente em espanhol. Nesse sentido, a hipótese da convergência linguística do uso de formas semelhantes no português uruguaio é refutada.

II. A expansão do pronome a gente está mais avançada na função de sujeito, pois é a posição privilegiada no português uruguaio, assim como no português brasileiro. Segundo Omena (1996, p. 191), o caminho da mudança linguística passa pela função de adjunto adverbial, sujeito e complemento, e começa a atingir os possessivos em função de adjunto adnominal. No caso do português brasileiro de Aceguá, a mudança se dá preferencialmente pela função sujeito, adjunto adverbial, objeto indireto e adjunto adnominal. E no português uruguaio de Aceguá, a diferença é que o objeto indireto aparece com maior frequência do que o adjunto adverbial.

III. A frequência de a gente no português brasileiro de Aceguá $(58,6 \%$ ou $63,4 \%)$ encontra-se mais avançada do que no português uruguaio (29.3\% ou 49,1\%), 
respectivamente na análise com todos os colaboradores ou na análise sem os casos categóricos de nós.

No caso do português brasileiro de Aceguá (Rio Grande do Sul), a frequência de uso é de 58,6\% na análise com todos os colaboradores e 63,4\% na análise sem os casos categóricos. Por isso, acompanha os altos índices de a gente na região Sul do Brasil, como Pelotas (78\%) e Florianópolis (72\%), Jaguarão (69\%), Porto Alegre (69\%), Curitiba (64\%) e Blumenau (60\%). Além da região Sul, o português brasileiro de Aceguá na análise sem os categóricos também se aproximou dos falantes do Rio de Janeiro (de 79\% a 59\%), na região Sudeste.

O resultado do português uruguaio com todos os colaboradores $(29,3 \%)$ se assemelha, em termos de distribuição, ao português europeu, com menos de $26 \%$ (VIANNA, 2011). O resultado do português uruguaio sem os casos categóricos em nós (49.1\%) se aproxima mais da variedade de Santa Catarina em Blumenau (51\%), Concordia (50\%) e Chapecó (48\%) e também do português europeu (42\%) (RUBIO, 2012). Além da região Sul, a frequência de 49,1\% do português uruguaio da fronteira se aproxima de comunidades mais isoladas e rurais como Brasilândia - SP no Sudeste (53\%) e Cinzento - BA no Nordeste (56\%). Ao mesmo tempo, Ponta Porã - MS, no Centro-Oeste, tem frequência ainda inferior, de 39\%, e Piabas-BA, no Nordeste, tem a maior frequência de todas essas comunidades mais isoladas, com $62 \%$.

Percebe-se, portanto, que o português uruguaio e o português brasileiro são distintos entre eles em termos de distribuição dos dados. Os percentuais de Aceguá chegam a $63,4 \%$ na análise brasileira e a $49,1 \%$ na análise uruguaia, o que revela a proximidade do português brasileiro de Aceguá $(63,4 \%)$ com a maioria das variedades do português brasileiro, que estão utilizando cada vez mais o pronome a gente como primeira pessoa do plural. Na maior parte da região Sudeste, Sul, Nordeste e CentroOeste, o uso de a gente está acima de 70\%. Já no português uruguaio, (com no máximo 49,1\%), a expansão do a gente é mais comedida.

Em outras fronteiras do Rio Grande do Sul, como o caso de Flores da Cunha (italiano-português) e Panambi (alemão-português) e São Borja (espanhol-português), nota-se que as comunidades bilíngues acompanham mais lentamente a mudança com relação à inserção de a gente no sistema pronominal, ainda que a tendência seja na direção do uso dessa forma inovadora (ZILLES, 2007, p. 36). Pelotas e Jaguarão, fronteiras com Uruguai, também compõem localidades menores, mais rurais e, portanto, 
com mais contato linguístico e/ou bilinguismo, o que deixa o ritmo da mudança mais lento (ZILLES, 2007, p. 37).

IV. O grau de bilinguismo dos uruguaios interfere no uso de a gente, porque, provavelmente, o fato de os falantes serem bilíngues licencia o uso do pronome a gente, que é tipicamente brasileiro. Os falantes monolíngues uruguaios, por sua vez, não utilizam esse pronome como primeira pessoa do plural, já que no espanhol la gente significa "as pessoas, os povos". A identidade cultural dos colaboradores reflete, de certa forma, o bilinguismo de cada um, ou seja, os colaboradores que se dizem uruguaios são bilíngues em português e espanhol, enquanto os que se consideram brasileiros, em sua grande maioria, são monolíngues em português. Então, quanto mais contato direto com o português brasileiro e com o Brasil, maior o uso de a gente pelos uruguaios bilíngues.

V. Na análise variacionista, os fatores linguísticos e sociais que operam no português brasileiro e no português uruguaio (sem os casos categóricos de nós) são semelhantes, quanto ao favorecimento do pronome sujeito a gente nos contextos de: (i) faixa etária jovem, (ii) sujeito explícito, (iii) referência genérica, (iv) dados de a gente precedidos de a gente, e (v) tempo verbal do presente. A função sintática e a concordância são analisadas apenas em percentagens, e o sexo não foi selecionado em nenhuma análise.

O resultado aponta para uma diferença social e duas linguísticas. No primeiro caso, a análise uruguaia com todos os colaboradores mostra os adultos favorecendo $a$ gente por questões de mobilidade social e geográfica e pela existência de falantes que usam categoricamente o nós. A diferença linguística está no tempo verbal, já que o pretérito perfeito sem neutralização favorece a gente na análise uruguaia e desfavorece na análise brasileira; e no tipo de referência, já que não é selecionada na análise uruguaia, mas é selecionada na análise brasileira.

O pronome a gente também é utilizado da mesma forma que ocorre no espanhol, ou seja, faz referência à pluralidade de pessoas na terceira pessoa, ao povo, que não inclui o falante, nem no plano sintático nem no semântico. Assim, há essa interpretação em quatro dados de bilíngues uruguaios e em um dado de uma brasileira. Assim, ainda há resquícios latinos da impessoalidade de a gente em cinco dados coletados, mas que 
estão em processo de mudança linguística nas duas comunidades, com um uso cada vez mais definido de primeira pessoa do plural.

Já a variável social, como faixa etária, demonstra diferenças importantes. No português brasileiro de Aceguá, a mudança linguística se dá na comunidade de forma mais estável (jovens usam mais a gente do que adultos), enquanto no português uruguaio a mudança se dá no indivíduo de forma instável (adultos usam mais a gente do que jovens). Dessa forma, a comunidade brasileira monolíngue parece estar mais em movimento de mudança do que a comunidade bilíngue uruguaia.

Sobre as possibilidades futuras de análise quantitativa desse próprio fenômeno, a variável escolaridade poderia ser melhor analisada e submetida à estatística somente para o português brasileiro de Aceguá, porque está melhor estratificada. No caso do preenchimento do sujeito, a única forma de romper certa circularidade do sujeito implícito singular de segunda ou demais posições equivalentes ao pronome a gente seria analisar apenas os casos de sujeito explícito. No entanto, como a comunidade de Aceguá não apresenta dados do tipo a gente vamos, a suposta circularidade diminui bastante. Outra possibilidade de analisar o fenômeno da alternância de primeira pessoa do plural juntamente com a concordância verbal seria analisar a variável dependente como eneária, ou seja, entre a gente fala, nós fala e nós falamos, ao invés da variável binária a gente e nós, uma vez que não há variação com a gente falamos em Aceguá.

VI. Partimos do pressuposto de que a inserção ou aquisição do pronome a gente como primeira pessoa do plural no português uruguaio pode ser consequência do contato linguístico com o português, porque esse pronome só existe na variedade brasileira dessa língua, e, por isso, quanto maior a proximidade com o Brasil maior a frequência de a gente. Percebe-se, portanto, que, ao se distanciar da fronteira, indo mais para o interior do Uruguai, os falantes já não utilizam o português como língua materna, uma vez que são monolíngues, e provavelmente, deixam de usar ou usam menos a gente como primeira pessoa do plural.

Aqui se deve lembrar que não havia registro do uso de a gente como primeira pessoa do plural no português uruguaio, uso este já bem consagrado no português brasileiro. 
VII. A identidade sociolinguística é formada e constituída também na fronteira e interfere no falar local. Assim, as variantes pronominais da primeira pessoa do plural podem ser associadas a algumas interpretações e simbologias.

O pronome a gente, para os uruguaios, seria o pronome da inovação, da aproximação a tudo que é brasileiro, ao que é, de certa forma, estrangeiro, diferente, típico de uma variedade monolíngue. Esse recurso linguístico também pode ser interpretado como algo típico do processo de urbanização, de modernização. A gente representaria os novos tempos, a inter-relação na fronteira, o polo econômico, social e político voltado para o Brasil.

O pronome nós simbolizaria o pronome do conservadorismo tanto no espanhol uruguaio (com o seu equivalente nosotros-as) quanto no português brasileiro, mas, como não existe a gente pronominalizado no espanhol, para os bilíngues ou monolíngues uruguaios, a tendência seria preservar cada vez mais sua identidade uruguaia com o uso do pronome nós. É o oposto ao estrangeiro, mas, ao mesmo tempo, como também é um pronome utilizado no Brasil, reflete bem a questão da multiplicidade de identidade, porque o bilíngue uruguaio, muitas vezes, se considera brasileiro e uruguaio, representado por ambas as variantes. Assim, o pronome nós simboliza também a questão da natividade, do nacionalismo e da identificação uruguaia.

Para complementar as respostas às questões de pesquisa, é importante também relembrar as evidências de que o pronome a gente seria uma mudança relativamente nova no português uruguaio. Entre elas se pode apontar que: (i) a variação pronominal de primeira pessoa do plural ainda não tinha sido investigada/encontrada no português uruguaio na década de 70, pois, segundo Elizaincín, Behares e Barrios (1987, p. 85), na época, o pronome a gente do lado uruguaio não tinha o mesmo significado do português brasileiro, diferenciando-se da primeira pessoa do plural e conservando o sentido impessoal, além de seu uso não ser sistemático e regular; (ii) a função sintática demonstra que o pronome a gente no português uruguaio aparece mais na posição de sujeito, menos expandido linguisticamente; (iii) enquanto outras variedades do português brasileiro utilizam a gente vamos, no português uruguaio ainda inexiste essa concordância não padrão, e, segundo Zilles (2007, p. 30), nas comunidades bilíngues do Rio Grande do Sul - São Borja, Flores da Cunha e Panambi; (iv) categoricidade do pronome nós em 9 entrevistas com uruguaios contra apenas 3 entrevistas com brasileiros, de um total de 19 entrevistas com brasileiros e 19 entrevistas com uruguaios. 
A partir de toda essa exposição, percebe-se que o português uruguaio de Aceguá não pode ser explicado sob o ponto de vista da mistura linguística, também porque, no caso do pronome de primeira pessoa do plural, em vez de reduzir a oposição entre $a$ gente indefinido (português arcaico e espanhol) e a gente pronominalizado (português brasileiro), utilizando as formas linguísticas semelhantes (nós e nosotros) nas duas línguas, a comunidade faz o contrário, ou seja, mantém a oposição de terceira pessoa do singular ou plural no espanhol e de primeira pessoa do plural no português. Nesse caso, não há simplificação, muito menos "empobrecimento", mas sim a entrada de um pronome em co-ocorrência com o nós no português também falado pelos uruguaios.

Esse uso também não é idiossincrático, mas variável. Portanto, não há convergência linguística para a variante comum nas duas línguas (nós e nosotros no português e no espanhol, respectivamente), uma vez que é a variante a gente do português que também faz parte do quadro pronominal do português uruguaio. A gente, na verdade, é cognato de la gente, e, portanto, essa semelhança deveria impedir (ou problematizar) a entrada do a gente gramaticalizado no português uruguaio, o que de fato não acontece. Com outras palavras, o pronome inovador a gente como primeira pessoa do plural se expande cada vez mais no português brasileiro e avança, inclusive, as fronteiras políticas entre Brasil e Uruguai.

O pronome a gente vem de fora, de uma variedade urbana em que esse elemento linguístico é mais usado e hoje constitui a forma mais natural, menos marcada para alguns grupos sociais, sobretudo para os que têm mais contato com o mercado ocupacional, como revela o padrão etário curvilinear com todos os dados, e para os que têm mais contato com o português brasileiro de forma mais ampla, como revela o padrão etário não curvilinear com os mais jovens à frente do uso de a gente sem os falantes de uso categórico do pronome nós. Assim, os falantes de Aceguá com menos contato com o Brasil e com o português brasileiro da fronteira, inclusive os jovens, ainda privilegiam o nós, até com o seu uso categórico. Talvez haja maior identidade local desses falantes com esse pronome, porque, como já foi dito, a gente não existe no espanhol como primeira pessoa do plural, mas o nós se correspondente diretamente com nosotros nessa língua. O fato é que esses falantes ainda não foram atingidos pelo $a$ gente, mais urbano. Quem tem menos mobilidade social e geográfica ainda mantém o pronome nós, que era a forma mais local. Em suma, o a gente está entrando via faixa etária mais jovem, com mais contato urbano. 
O papel da urbanização na conformação do português uruguaio parece evidente em outros fenômenos linguísticos. Carvalho (2003b, 2008) demonstra, também por meio de análises quantitativas, que há uma continuidade dialetal entre as duas variedades, comparando fenômenos linguísticos semelhantes do português uruguaio e do português brasileiro, como a variação da palatalização $/ \mathrm{h} / \mathrm{e} / \mathrm{di} / / \mathrm{ti} /$, consequência do fluxo da recente urbanização e, portanto, das formas socialmente prestigiadas. Por sua vez, Meirelles (2009) mostra que há um só inventário fonológico nos dois lados da fronteira, apesar do intenso contato com o espanhol. E, mais recentemente, Pacheco (2013) apresenta outra continuidade do português ao detectar uma mudança na morfossintaxe do português uruguaio com a entrada do pronome a gente na fronteira Brasil-Uruguai.

Todos esses resultados confirmam que o português uruguaio pertence a um continuum, como constatou Carvalho (2003b, p. 135), uma vez que a difusão e o contínuo de variação estilística e social fazem parte da transição de formas mais rurais para as mais urbanas.

De fato, uma das maiores diferenças dos trabalhos variacionistas para os trabalhos de Rona (1965), Elizaincín et alii (1987), Elizaincín (1992) e Hensey (1969/1972), é que a variação linguística é explicada a partir dos padrões linguísticos e sociais, e não da variação interna livre, ou seja, os usos são variáveis e regulares em determinados contextos. Nesse sentido, não se trata de mistura aleatória de línguas ou de fenômenos aparentemente categóricos, mas sim de sistemas variáveis como qualquer dialeto monolíngue.

Diante da complexidade da realidade linguística e social da fronteira, é notório que não se esgotam aqui as possibilidades de estudo do português uruguaio e do português brasileiro em Aceguá. Restam ainda outros desdobramentos de temas importantes para a análise quantitativa, tais como: quantificação do code-switching e dos empréstimos linguísticos (POPLACK, 1993 e MEYERHOFF, 2009), da concordância verbal e de gênero em correlação com a alternância pronominal de primeira pessoa do plural e de outros fenômenos variáveis, uma vez que esse é o primeiro estudo variacionista nessa amostra e em Aceguá.

Sobre os tipos de concordância, já é possível sinalizar que não há nenhum dado no português aceguaense de "a gente falamos". O único fator variável se apresenta quando o sujeito está implícito e o verbo no singular, já que os demais fatores estão em distribuição complementar. Assim, a frequência de concordância padrão é de $95 \%$ para 
os uruguaios e de $85 \%$ para os brasileiros, provavelmente reflexo da alta concordância do espanhol. A conjugação verbal "nós trabalhemo" é uma característica típica da região fronteiriça de Aceguá, mais frequente no português uruguaio, e pode ser interpretada como um traço de regiões tipicamente rurais, como é o caso dessa região, existente tanto no português brasileiro rural como no espanhol uruguaio rural.

Do ponto de vista qualitativo, pode-se ainda trabalhar com as paisagens linguísticas, redes sociais e atitudes sociolinguísticas. As paisagens linguísticas referemse ao estudo dos sinais públicos e comerciais. No nosso caso, há inúmeras fotos de placas e outdoors, tanto do lado do Brasil quanto do lado do Uruguai, que ora estão em suas respectivas línguas oficiais, ora estão nas duas línguas, ora estão na língua do país vizinho. É interessante observar como a relação exteriorizada com o meio ambiente também é reflexo de práticas linguísticas.

Entender como as redes sociais são formadas (MILROY, 1980) e as atitudes sociolinguísticas dos colaboradores ajuda também a analisar a interação e convívio entre os membros da comunidade e suas relações com o comportamento linguístico. As redes sociais podem ser constituídas a partir de observações participantes e das entrevistas com questões previamente elaboradas, no intuito de delimitar e codificar as redes no programa estatístico. Quanto menor o local, maior as relações entre os habitantes, e as interações tendem a ser maiores quando houver mais assimetria entre os moradores. Também é possível e recomendável relatar mais a experiência nas escolas e as questões linguísticas dentro do âmbito educacional, do bilinguismo.

Outra possibilidade de análise futura é aprofundar sobre a origem do português brasileiro em paralelo com a origem do português uruguaio, no sentido de identificar como a gente surge no Uruguai, ou seja, se a hipótese é de que o português uruguaio poderia ter passado por um processo de gramaticalização semelhante ao português brasileiro, mas independente ou decorrente do contato linguístico das duas línguas na fronteira. Assim, seria um processo extralinguístico ou próprio da deriva natural do português uruguaio (NARO e SCHERRE, 2007).

Para que todas essas análises sejam viáveis, é imprescindível cada vez mais que linguistas realizem pesquisa de campo e registrem os diversos falares espalhados pelo Brasil e pelo mundo. Somente assim é possível conhecer e legitimar a realidade (socio)linguística dos povos, especialmente dos minoritários, que pouco são representados política e economicamente, ainda mais em se tratando de localidades fronteiriças e isoladas. 
AGUIAR, Ofir Bergemann de. O pronome on na tradução do conto "L'aveugle", de Maupassant: os estudos lingüísticos sub-frásticos devem ser ainda considerados? Tradterm, [S.1.], v. 8, p. 81-98, Abr. 2002. Disponível em: <http://www.revistas.usp.br/tradterm/article/view/49122>. Acesso em: 5 out. 2014.

ALKMIM, Tânia Maria. Sociolinguística: parte I. In: MUSSALIM, Fernanda; BENTES, Anna Chiristina. Introdução à linguística: domínios e fronteiras. 5. ed. São Paulo: Cortez, 2005. V. 1. p. 21-47.

AMARAL, Tatiana Ribeiro do. Una comunidad de habla, dos comunidades de lengua: la alternancia de códigos como signo de identidad en la frontera brasileño-uruguaya. 2008. Tese (Doutorado em Lengua Española y Lingüística General) - Universidad Autonoma de Madrid, Madri.

ANTONINO, V.; BANDEIRA, M. Nós, a gente e a concordância em uma comunidade afro-brasileira isolada. Papia, São Paulo, v. 1, n. 21, p. 159-176, 2011.

ARTEAGA, Juan José. Breve historia contemporánea del Uruguay. 1. ed. Buenos Aires: Fondo de Cultura Económica, 2008.

ABREU, João Capistrano de. Capítulos de história colonial: 1500-1800 \& Caminhos antigos e o povoamento do Brasil. 2. ed. Brasília: Ed. Universidade de Brasília, 1998.

AVEIRO, Thais Mere Marques. Relações Brasil-Uruguai: a nova agenda para a cooperação e o desenvolvimento fronteiriço. 2006. Dissertação (Mestrado em Relações Internacionais). Universidade de Brasília, Brasília.

BAGNO, Marcos. A norma oculta: língua e poder na sociedade brasileira. São Paulo: Parábola, 2003.

. Dramática da língua portuguesa. São Paulo: Loyola, 2005.

Nada na língua é por acaso: por uma pedagogia da variação linguística. São Paulo: Parábola, 2007.

BANDEIRA, Luiz Alberto Moniz. O expansionismo brasileiro e a formação dos Estados na Bacia do Prata: Argentina, Uruguai e Paraguai, da colonização à Guerra da Tríplice Aliança. 3. ed. Rio de Janeiro: Revan; Brasília: Ed. Universidade de Brasília, 1998.

BARRIOS, Graciela; BEHARES, Luis, ELIZAINCÍN, Adolfo. Nos falemo brasilero: Dialectos portugueses em Uruguay. Montevideo: Amesur, 1987.

BAUMAN, Zygmunt. Modernidade líquida. Tradução: Plínio Dentzien. Rio de Janeiro: Zahar, 2001.

BEHARES, Luis E. Breves noticias sobre el Portugués de Uruguay. (inédito), 2010. 
BISOL, Leda. O alçamento da pretônica sem motivação aparente. In: BISOL, Leda; COLLISCHONN, Gisela (orgs). O português do sul do Brasil: variação fonológica. Porto Alegre: EDIPUCRS, 2009. p. 73-92.

BORBA, L. R. Alguns aspectos sobre o uso de 'nós' e 'a gente' em Curitiba. Fragmenta, Curitiba, n. 10, p. 65-76, 1993.

BORGES, P. R. S. A. A gramaticalização de "a gente” no português brasileiro. Porto Alegre. Tese (Doutorado em Letras). Programa de Pós-Graduação em Letras, Universidade Federal do Rio Grande do Sul, Porto Alegre, 2004.

BORTONI-RICARDO, Stella Maris. A análise do português em três continua: o continuum rural-urbano, o continuum de oralidade-letramento e o continuum de monitoração estilística. In: GROBE, S. \& ZIMMERMANN, K. <<Substandard >>e mudança no português do Brasil. Frankfurt am Main: TFM, 1998. p. 101-118.

Educação em língua materna: a sociolinguística na sala de aula. São Paulo: Parábola, 2004.

. The urbanization of rural dialect speakers. Cambridge: Cambridge University Press, 1985.

BRUSTOLIN, Ana Kelly Borba da Silva. Uso e variação de nós e a gente na fala e escrita de alunos do ensino fundamental. In: IX Encontro do CELSUL, 2010, Palhoça, SC. Anais. Palhoça-SC: Universidade do Sul de Santa Catarina. 2010. Disponível em: http://www.celsul.org.br/Encontros/09/artigos/Ana\%20Brustolin\%20_1.pdf. Acesso em: 22 ago. 2014.

CALÓGERAS, J. Pandiá. Formação Histórica do Brasil. Companhia Editora Nacional. São Paulo, 1972.

CÂMARA JR, Joaquim Mattoso. Estrutura da Língua Portuguesa. 36. Ed. Petrópolis: Vozes, 2004.

CAMÕES, Luís Vaz de. Obra Completa. Rio de Janeiro: Nova Aguilar, 2003.

CAMÕES, Luís Vaz de. Os Lusíadas. Antologia. Ed. Por Evanildo Bechara e Segismundo Spina. Disponível em: <http://books.google.com.br/books?id=I_ T9Fqq5A7cC\&printsec $=$ frontcover \&dq $=$ os + lusiadas \&hl $=$ en \&sa $=X \& e i=b P o a V N i F F c T$ BggSmm4D4Cg\&ved=0CD8Q6wEwBA\#v=onepage $\& \mathrm{q}=0 \mathrm{os} \% 201 \mathrm{usiadas} \& \mathrm{f}=$ false $>$.

Acesso em: 18 set. 2014.

CARDOSO, Caroline Rodrigues. Pesquisa quantitativa e qualitativa em Sociolinguística: dadaísmo metodológico? Cadernos de Letras da UFF, n. 46, p. 143156, 2013.

CARVALHO, Ana Maria. Code-switching: From theoretical to pedagogical considerations. In: BEAUDRIE, S.; FAIRCLOUGH, M. (Eds.). Spanish as a heritage language in the United States: State of the field. Washington, DC: Georgetown University Press. 2012. 
Eres de la frontera o sos de la capital? Variation and alternation of secondperson verbal forms in Uruguayan border Spanish. Southwest Journal of Linguistics. 29, $1,2010$.

I speak like the guys on TV: Palatalization and the urbanization of Uruguayan Portuguese. Language Variation and Change, n. 16, p. 127-151. 2004. [Tradução brasileira: “'Eu gosto do jeito da Globo falar português': Palatalização e urbanização do português uruguaio"] In: ESPIGA, Jorge; ELIZAINCÍN, Adolfo (eds.). Español y portugués: um (velho) Novo Mundo de fronteiras e contatos. Pelotas-RS: Educat, 2008.

Políticas lingüísticas de séculos passados nos dias de hoje: O dilema sobre a educação bilingüe no norte do Uruguai. Language Problems \& Language Planning 30 (2), 2006. p. 149-171.

Rumo a uma definição do português uruguaio. Revista internacional de linguística iberoamericana, n. 2, p. 125-149, 2003.

Spanish (s) aspiration as a prestige marker on the Uruguayan-Brazilian border. Amsterdam: Spanish in Context, John Benjamins Publishing Company, 2006. p. 85114.

The Sociolinguistic Distribution of (lh) in Uruguayan Portuguese: A case of dialect diffuscion. In: MONTRUL, S.; ORDÓÑEZ, F (Eds.). Linguistic Theory and Language Development in Hispanic Languages. Somerville, MA: Cascadilla Press, 2003. p. 30-44.

CASTILHO, Ataliba T. de. Nova gramática do português brasileiro. 1. ed., 1. Reimp. São Paulo: Contexto, 2010.

CASTROGIOVANNI, Antonio Carlos. Fronteira: Um tema sem limites! In: COSTA, Edgar Aparecido da; COSTA, Gustavo Villela Lima da; OLIVEIRA, Marco Aurélio Machado de (Orgs.). Estudos fronteiriços. Campo Grande, MS: Ed. UFMS, 2010. p. 1141.

COELHO, R. É nóis na fita! Duas variáveis linguísticas numa vizinhança da periferia paulistana. 2006. Dissertação (Mestrado em Linguística) - Faculdade de Filosofia, Letras e Ciências Humanas, USP, São Paulo.

CORACINI, Maria José. Identidade \& discurso: (des)construindo subjetividades. Campinas: Ed. da UNICAMP; Chapecó: Argos Editora Universitária, 2003.

CORDER, S. P. Dialectos idiosincrásicos y análisis de errores. In: LICERAS, Juana Muñoz. La adquisición de las lenguas extranjeras. Madrid: Visor Lingüística y Conocimiento, 1992. p. 63-77.

COSTA, Gustavo Villela Lima da. As fronteiras da identidade em Corumbá-MS: Significados, discursos e práticas. In: COSTA, Edgar Aparecido da; COSTA, Gustavo Villela Lima da; OLIVEIRA, Marco Aurélio Machado de (org.). Estudos fronteiriços. Campo Grande, MS: Ed. UFMS, 2010. p. 69-97. 
COUTO, Hildo Honório. Comunidade e linguagem na costa da Guiné nos séculos XV, XVI e XVII. Polifonia, Cuiabá, n. 7, p. 87-102, 2003.

2009.

Contato português-espanhol na fronteira Brasil-Uruguai. São Paulo: Contexto,

Ecolinguística: estudo das relações entre língua e meio ambiente. Brasília:

Thesaurus, 2007.

Hipótese da relexificação na gênese dos crioulos e pidgins. Revista da ABRALIN, v. 1, n. 1, p. 221-250, jul. 2002.

1996.

Introdução ao estudo das línguas crioulas e pidgins. Brasília: Editora da UnB,

Linguística, ecologia e ecolinguística - contato de línguas. São Paulo: Contexto, 2009.

Prolegômenos ao estudo do acento em português. Polifonia, Cuiabá, v.12, n. 2, p. 73-89, 2006.

Sobre o conceito de comunidade surda. Revista de Estudos da Linguagem, Belo Horizonte, v. 13, n. 2, p. 193-219, jul./dez. 2005.

CRUZ, Maria Luisa Segura da. O falar de Odeleite. Lisboa: Instituto Nacional de Investigação Científica, Centro de Lingüística da Universidade de Lisboa. Barbosa \& Xavier, Limitada, Série: Linguística 16, 1991.

DEALTRY, Giovanna Ferreira. Memória e esquecimento como formas de construção do imaginário da nação. In: LOPES, Luiz Paulo da Moita; BASTOS, Liliana Cabral. Identidades: recortes multi e interdisciplinares. Campinas, SP: Mercado das Letras, 2002. p. 189-201.

DETTONI, Rachel do Valle. A concordância de gênero na anáfora pronominal: variação e mudança linguística no dialeto da baixada cuiabana - Mato Grosso. 2003. Tese (Doutorado em Estudos Linguísticos) - Universidade Federal de Minas Gerais, Belo Horizonte.

DETTONI, Rachel do Valle; PACHECO, Cíntia da Silva; ANDRADE, Carolina Queiroz; SCHERRE, Maria Marta Pereira. Projeto de variação linguística no CentroOeste (VALCO). Alfa, São Paulo, n. 56, p. 807-833, 2012.

DICIONÁRIO MULTILÍNGÜE: Português, Inglês, Francês, Alemão, Italiano, Espanhol. Reader's Digest Brasil Ltda, 1998.

DOUGLAS, Kendra Lynne. Uruguayan portuguese in Artigas: tri-dimensionality of transitional local varieties in contact with Spanish and Portuguese standards. 2004. Tese (Doutorado em Linguística) - University of Wisconsin-Madison.

DUARTE, M. Eugênia L. A perda do princípio "Evite Pronome" no português brasileiro. 1995. Tese (Doutorado em Estudos da Linguagem), Unicamp, Campinas. 
ELIZAINCÍN, Adolfo. Dialectos en contacto: Español y portugués en España y América. Montevidéu: Arca, 1992.

ELIZAINCÍN, A., L. BEHARES y G. BARRIOS. Nós falemo brasilero. Dialectos portugueses en el Uruguay. Montevideo, Amesur, 1987.

ESCOBAR, Anna María. Contact features in Colonial Peruvian Spanish. Int'l. J. Soc. Lang. n. 149, p. 79-93, 2001.

ESPIGA, J. O contínuo português-espanhol: contato e variação linguística. In: ESPIGA, Jorge; ELIZAINCÍN, Adolfo (eds.). Español y portugués: um (velho) Novo Mundo de fronteiras e contatos. Pelotas-RS: Educat, 2008. p. 373-404.

FAGUNDES, Edson Domingos. As ocorrências do Modo Subjuntivo nas entrevistas do VARSUL no Estado do Paraná e as possibilidades de variação com o Modo Indicativo. 2007. Tese (Doutorado em Lingüística) - Programa de Pós-Graduação em Letras, Universidade Federal do Paraná, Curitiba.

FARACO, Carlos Alberto. Lingüística histórica: uma introdução ao estudo da história das línguas. São Paulo: Parábola, 2005.

FARACO; MOURA. Gramática. São Paulo: Ática, 2002.

FAULSTICH, Enilde. O portunhol é uma interlíngua? Seminário apresentado no Institut Universitari de Lingüística Aplicada (IULA), Universitat Pompeu Fabra (UPF), Barcelona, em 21 de abril de 1997.

FELGUEIRA, Carmen Maria. Análise da Variação no uso da Preposição PARA. 1993. Dissertação (Mestrado em Linguística) - Universidade Federal do Rio de Janeiro, Rio de Janeiro.

FERNANDES, E. A. Nós x a gente: variação estável ou mudança em progresso? In: SOARES, M. E.; ARAGÃO, M. S. S. (Eds.). Anais da XVI Jornada de Estudos Linguísticos. Fortaleza: UFC/GELNE, 1999. p. 331-334.

FERNANDEZ, Sonsoles. Interlengua y análisis de errores en el aprendizaje del español como lengua extranjera. Madrid: Edelsa, 1997.

FLICK, Uwe. Introdução à pesquisa qualitativa. Tradução Joice Elias Costa. 3.ed. Porto Alegre: Artmed, 2009.

FRANCESCHINI, Lucelene Teresinha. Variação pronominal nós/a gente e tu/você em Concórdia - SC. 2011. Tese (Doutorado em Letras) - Universidade Federal do Paraná, Curitiba.

GARRETT, Paul B. Language Contact and Contact Languages. In: MALDEN, A. Duranti (Ed.) A Companion to Linguistic Anthropology. Oxford, UK: Blackwell Publishing, 2006. p. 46-72.

GIDDENS, A. Modernidade e identidade. Rio de Janeiro: Jorge Zahar Editora, 2002.

GOLIN, Tau. A fronteira: volume 2. Porto Alegre: L\&PM, 2004. 
GÜNTHER, Hatmut. Pesquisa Qualitativa versus Pesquisa Quantitativa. Psicologia: Teoria e Pesquisa (UnB), v. 22, n. 2, p. 201-210. 2006.

GUY, Gregory; ZILLES, Ana. Sociolinguística quantitativa: instrumental de análise. São Paulo: Parábola, 2007.

HAESBAERT, Rogério. Fim dos territórios ou novas territorialidades? In: LOPES, Luiz Paulo da Moita; BASTOS, Liliana Cabral. Identidades: recortes multi e interdisciplinares. Campinas, SP: Mercado das Letras, 2002. p. 29-53.

HALL, S. A identidade cultural na pós-modernidade. Rio de Janeiro: DP e A, 2005.

HARTMANN, Luciana. A circulação de narrativas orais na fronteira entre Argentina, Brasil e Uruguai. In. COSTA, Edgar Aparecido da; COSTA, Gustavo Villela Lima da; OLIVEIRA, Marco Aurélio Machado de (Orgs.). Estudos fronteiriços. Campo Grande, MS: Ed. UFMS, 2010.

HENSEY, Frederik Gerald. O sociolinguismo da fronteira sul. Letras de hoje, n. 3, p. 107-116. 1969. 1972.

The sociolinguistics of the Brazilian Uruguayan border. La Haya: Mouton,

HERMOSO, A. González; CUENOT, J. R.; ALFARO, M. Sánchez. Gramática de español lengua extranjera. Curso Prático. Edelsa: Grupo Didascalia, 2006.

HOLANDA, Sergio Buarque de. História geral da civilização brasileira. O Brasil monárquico, tomo II: o processo de emancipação. Por Celia de Barros Barreto [et al.]. 9. ed. v. 3. Rio de Janeiro: Bertrand Brasil, 2003. p. 341-415.

ILARI, Rodolfo. Lingüística Românica. 3. ed. São Paulo: Ática, 2006.

ILARI, Rodolfo; BASSO, Renato. O português da gente: a língua que estudamos a língua que falamos. São Paulo: Contexto, 2006.

IVO, Elda Alves Oliveira. O letramento de adultos na empresa: uma formação de legitimar a alienação ou uma questão de sobrevivência? Tese (Doutorado em Linguística) - UnB, 2013.

LABOV, William. Padrões Sociolinguísticos. Tradução Marcos Bagno, Maria Marta Pereira Scherre, Caroline Rodrigues Cardoso. São Paulo: Parábola, 2008 [1972].

Principles of linguistic change. Volume 2: Social factors. Cambridge: Blackwell Publishers, 2001.

. The functional characater of change. In: Language and Society 20. Principles of Linguistic Change - Internal Factors. Cambrige: Blackwell, 1994. p. 545-605.

The Social Stratification of English in New York City. 2. ed. Cambridge: Cambridge University Press, 2006. 
Where does the sociolinguistic variable stop? A response to Beatriz Lavandera. Working papers in Sociolinguistics, n. 44, p. 1-22. 1978.

. What can be learned about change in progress from synchronic description? In: SANKOFF, D. (ed). Variation Omnibus. [NWAVE VIII]. Edmonton: Linguistic Research, 1981. p. 177-200.

LASH, S. Modernização reflexiva: política, tradição e estética na ordem social moderna. In: GIDDENS, A.; ULRICH, G. (Orgs.). A vida em uma sociedade póstradicional. São Paulo: Unesp, 1997. p. 73-133.

LAVANDERA, Beatriz. Where does the sociolinguistic variable stop? Language in Society, n. 7, p. 171-183. 1978.

LEFFA, V. J. Metodologia no ensino de línguas. In: BOHN, H. I.; VANDRESEN, P. Tópicos em Lingüística Aplicada: O Ensino de Línguas Estrangeiras. Florianópolis: Ed. da UFSC, 1988. p. 211-236.

LEITE de VASCONCELOS, J. Esquisse d'une dialectologie portugaise. 3. ed. Lisboa: Instituto Nacional da Universidade de Lisboa, Centro de Lingüística da Universidade de Lisboa, Lisboa, 1987/1901.

LERAY, Christian. A língua como vetor identitário: o caso particular do gaulês na Bretanha. In: CORACINI, Maria José. Identidade \& discurso: (des)construindo subjetividades. Campinas: Ed. da UNICAMP; Chapecó: Argos Editora Universitária, 2003. p. 119-136.

LIMA, Oliveira. Formação histórica da nacionalidade brasileira. 3. ed. Rio de Janeiro: Topbooks; São Paulo: Publifolha, 2000. (Grandes nomes do pensamento brasileiro).

LIPSKI, John M. Code-switching or Borrowing? No sé so no puedo decir, you know. In: SAYAHI, Lotfi; WESTMORELAND, Maurício. Selected Proceedings of the Second Workshop on Spanish Sociolinguistics. Somerville, MA: Cascadilla Proceedings Project, 2005. p. 1-15.

LOPES, C. R. S. A indeterminação no português arcaico e a pronominalização de nominais: mudança encaixada? In: V Encontro Internacional de Estudos Medievais da Abrem, 2003a, Salvador. Anais. Salvador, 2003a.

A inserção de 'a gente' no quadro pronominal do português. Frankfurt am Main/Madrid: Vervuert/Iberoamericana, v.18, 2003 b.

Nós e a gente no português falado culto do Brasil. DELTA, v.14, n. 2, São Paulo. Disponível em: http://www.scielo.br/scielo.php?script=sci_arttext\&pid=S010244501998000200006\&lng=en\&nrm=iso\&tlng=pt. Acesso em: 02 ago. 2014.

LOPES, C. R. S. Nós por a gente: uma contribuição da pesquisa sociolingüística ao ensino. In: CARDOSO, Suzana Alice Marcelino (org.). Diversidade Lingüística e Ensino. Salvador: EDUFBA, 1996. p. 115-123. Disponível em: <http://acd.ufrj.br/ pead/tema14/ponto25.html>. Acesso em: 17 mar. 2013. 
LOPES, Luiz Paulo da Moita; BASTOS, Liliana Cabral. Identidades: recortes multi e interdisciplinares. Campinas, SP: Mercado das Letras, 2002.

LUCCHESI, Dante. A variação na concordância de gênero em uma comunidade de fala afro-brasileira - Novos elementos sobre a formação do português popular do Brasil. 2000. Tese (Doutorado em Linguística) - UFRJ, Rio de Janeiro.

Variação e norma: elementos para uma caracterização sociolinguística do português do Brasil. Revista Internacional de Língua Portuguesa, Lisboa, v. 12, p. 1728, 1994.

MACHADO, Marcia dos Santos. Sujeitos pronominais "nós" e "a gente": variação em dialetos populares do norte fluminense. 1995. Dissertação (Mestrado em Língua Portuguesa) - UFRJ, Faculdade de Letras, Rio de Janeiro.

MAIA, Francisca Paula Soares. A variação nós/a gente no dialeto mineiro: investigando a transição. Revista da ABRALIN, Belo Horizonte, v. 8, n. 2, p. 45-70, jul/dez. 2009.

Ocorrências e referências de la gente em língua hispânica. In: V Congresso Brasileiro de Hispanistas - I C. Internacional da ABH, 2009, Belo horizonte. Anais. Belo Horizonte: FALE/UFMG, 2008. p. 2659-2666. Disponível em: <http://www.letras.ufmg.br/espanhol/Anais/anais_paginas\%20_2502-

3078/Ocorr\%EAncias\%20e\%20refer\%EAncias.pdf>. Acesso em: 2 mai. 2014.

MARTIN, John W. "Gênero". In: Revista Brasileira de linguística, ano 1, 2ºmestre, p. 3-8, 1975.

MATTOS, Shirley Eliany Rocha. A primeira pessoa do plural em Goiás. 2013. Tese (Doutorado em xx) - Universidade de Brasília, Brasília..

MATTOS e SILVA, Rosa Virgínia. O português arcaico: fonologia, morfologia e sintaxe. São Paulo: Contexto, 2006.

MEIRELLES, Virginia. Aspectos fonológicos do contato entre o português e o espanhol na cidade de Sant'ana do Livramento-Rivera. 2006. Dissertação (Mestrado em Linguística) - Universidade de Brasília, Brasília.

. Elementos de fonética do português falado no Rio Grande do Sul. 2011. Tese (Doutorado em Linguística) - Universidade de Brasília..

O português da fronteira Brasil-Uruguai. In: CARVALHO, Ana Maria. $O$ português em contato. V. 2. Madrid/Frankfurt: Editora Vervuert/Iberoamericana, 2009. (Série Linguística Luso-Brasileira). p. 257-275.

MENDONÇA, A. K. Nós $e$ a gente em Vitória: análise sociolinguística da fala capixaba. 2010. Dissertação (Mestrado em Linguística) - Pós-graduação em Estudos Linguísticos do Centro de Ciências Humanas e Naturais da Universidade Federal do Espírito Santo, Vitória.

MEYERHOF, Miriam. Replication, transfer, and calquing: Using variation as a tool in the study of language contact. Language Variation and Change, 21 (2009), pp. 297-317, Cambridge University Press, 2009. 
Introducing Sociolinguistics. 2. ed. London, New York: Routledge, 2006.

MILROY, Lesley. Language and social networks. Oxford: Basil Blackwell, 1980.

MILROY, L.; GORDON, M. Sociolinguistics: method and interpretation. Oxford: Blackwell, 2003.

MIRA, Maria Helena Farmhouse da Graça. Algumas contribuições para um estudo da fonética, morfologia, sintaxe e léxico da linguagem popular de Lisboa. Dissertação (Licenciatura em Filologia Românica) - Faculdade de Letras, Universidade de Lisboa, Lisboa, 1954

MONTES-ALCALÁ, Cecilia. Dear amigo: Exploring code-switching in personal letters. In: SAYAHI, Lotfi; WESTMORELAND, Maurício. Selected Proceedings of the Second Workshop on Spanish Sociolinguistics. Somerville, MA: Cascadilla Proceedings Project, 2005. p. 102-108.

MOTA, Sara dos Santos. Portuñol, sujeito e sentido: efeitos de uma política educacional em Noite nu Norte. Abehache, São Paulo, ano 2, n 3. jul./dez. 2012. Disponível em: <http://www.hispanistas.org.br/abh/images/stories/revista/Abehache_n3/127-144.pdf>. Acesso em: 2 jun. 2014.

MUNIZ, Cleuza Andrea Garcia. Nós $e$ A gente: Traços sociolinguísticos no assentamento. 2008. Dissertação (Mestrado em Estudos da Linguagem) - UFMS, Campo Grande.

MUYSKEN, Pieter. Two linguistic systems in contact: grammar, phonology and lexicon. In: BHATIA, Tej K.; RITCHIE, William C. The handbook of bilingualism and multilingualism. 2. ed. UK: Blackwell, 2013. p. 148-168.

MYERS-SCOTTON, Carol. Codeswitching. In: COULMAS, Florian (Ed.). Handbook of Sociolinguistic. Oxford. Blackwell, 1997h. p. 217-237.

NARO, Anthony Julius. Modelos quantitativos e tratamento estatístico. In: MOLLICA, Maria Cecília; BRAGA, Maria Luiza (Orgs.) Introdução à sociolinguística: o tratamento da variação. São Paulo: Contexto, 2004. p. 15-27.

O dinamismo das línguas. In: MOLLICA, Maria Cecília; BRAGA, Maria Luiza (Orgs.) Introdução à sociolinguística: o tratamento da variação. São Paulo: Contexto, 2004. p. 44-50.

NARO, Anthony Julius; SCHERRE, Maria Marta Pereira. Garimpo das origens do português brasileiro. São Paulo: Parábola, 2007.

NARO, Anthony Julius; GÖRSKI, Edair; FERNANDES, Eulália. Change without change. In: Language variation and change, 11, p. 197-211. Cambridge U. Press, 1999.

NARO, A. J.; SCHERRE, M. M. P.; FOEGER, C. C.; BENFICA, S. A. Linguistic and social embedding of variable concord with 1st plural nós 'we' in Brazil. Texto inédito, submetido para publicação aos organizadores do 1st International symposium on variation in Portuguese, realizado no Centro de Estudos Humanísticos, Universidade do Minho, Braga, Portugal, 2014. 
NEMSER, W. Aproximative systems of foreign language learners. Iral, v. IX, n. 2, p. $115-123,1971$.

NETO, José Borges. Ensaios de Filosofia da Linguística. São Paulo: Parábola, 2004.

NEVES, Maria Helena de Moura. Gramática de usos do português. São Paulo: Ed. UNESP, 2000.

Pronomes. In: CASTILHO, Ataliba Teixeira de; ILARI, Rodolfo; NEVES, Maria Helena de Moura (Orgs). Gramática do português culto falado no Brasil. Campinas, SP: Ed. UNICAMP, 2008.

Que gramática estudar na escola? 3. ed., 2. reimp. São Paulo: Contexto, 2009.

OLINTO, Heidrun Krieger. Carteiras de identidade(s) de validade limitada. In: LOPES, Luiz Paulo da Moita; BASTOS, Liliana Cabral. Identidades: recortes multi e interdisciplinares. Campinas, SP: Mercado das Letras, 2002. p. 257-267.

OLIVEIRA, Isabela B; MOZZILLO, Isabella. Origem e os usos do termo "pidgin". In: Congresso de iniciação científica, 22, 2013, Pelotas, RS. Anais. Pelotas, RS: Universidade Federal de Pelotas. 2013.

OLIVEIRA, Marco Antônio. Variável linguística: conceituação, problemas de descrição gramatical e implicações para a construção de uma teoria gramatical. Delta, São Paulo, v. 3, n 1, p. 19-34, 1987.

OLIVEIRA, Marco Aurélio Machado de; OLIVEIRA NETO, Antônio Firmino de. A fronteira, a imigração e o fetiche do trabalho: significações internacionais. In: COSTA, Edgar Aparecido da; COSTA, Gustavo Villela Lima da; OLIVEIRA, Marco Aurélio Machado de (orgs.). Estudos fronteiriços. Campo Grande, MS: Ed. UFMS, 2010. p. 319-334.

OLIVEIRA, Sandra Carneiro. Nós e a gente em caimbongo: aspectos sócio-históricos e sociolingüísticos de uma comunidade afro-brasileira. 2008. Dissertação (Mestrado em Estudos de Linguagens) - UEB, Salvador.

OMENA, N. P.; BRAGA, M. L. A gente está se gramaticalizando? In: MACEDO, A. T.; RONCARATI, C.; MOLLICA, M. C. (orgs.) Variação e discurso. Rio de Janeiro: Tempo Brasileiro, 1996. p. 75-84.

OMENA, N. P. A referência à primeira pessoa do discurso no plural. In: OLIVEIRA e SILVA, Giselle Machline de; SCHERRE, Maria Marta Pereira Scherre. Padrões Sociolinguísticos: análises de fenômenos variáveis do português falado na cidade do Rio de Janeiro. Rio de Janeiro: Tempo Brasileiro, 1996. p. 183-215.

A referência à primeira pessoa do plural: variação ou mudança? In: PAIVA, Maria da Conceição; DUARTE, Maria Eugênia Lamoglia (orgs.). Padrões Sociolinguísticos: análises de fenômenos variáveis do português falado na cidade do Rio de Janeiro. Rio de Janeiro: Contra Capa Livraria, 2003. p. 63-80.

As influências sociais na variação entre nós e a gente na função de sujeito. In: OLIVEIRA e SILVA, Giselle Machline de; SCHERRE, Maria Marta Pereira Scherre. 
Padrões Sociolinguísticos: análises de fenômenos variáveis do português falado na cidade do Rio de Janeiro. Rio de Janeiro: Tempo Brasileiro, 1996. p. 309-323.

PACHECO, Cíntia da Silva. Padrões sociolinguísticos da concordância de gênero da baixada cuiabana. 2010. Dissertação (Mestrado em Linguística) - Universidade de Brasília, Brasília, DF.

Primeiras reflexões sobre o português fronteiriço de Aceguá. In: CARDOSO, Caroline Rodrigues; SCHERRE, Maria Marta Pereira; SALLES, Heloísa; PACHECO, Cíntia da S. (orgs). Variação, mudança linguística e educação: Contribuições do III Encontro do Grupo de Estudos Avançados em Sociolinguística da Universidade de Brasília. Brasília: Pontes Editores, 2013. (Linguagem e Sociedade)

PAGOTTO, Emilio Gozze. Variação e (') identidade. Maceió: EDUFAL, 2004.

PEREIRA, Sandra Maria de Brito. Gramática Comparada de a gente: variação no Português Europeu. 2003. Dissertação (Mestrado em Gramática Comparada) Faculdade de Letras, Universidade de Lisboa, Lisboa.

PERINI, Mário A. Estudos de gramática descritiva: as valências verbais. São Paulo, Parábola, 2008.

POPLACK, Shana. Code-switching. In: AMMON, U.; DITTMAR, N.; MATTHEIER, K. J.; TRUDGILL, P. Soziolinguistik. An international handbook of the science of language. 2. ed. Berlin: Walter de Gruyter, 2004. p. 589-596.

Function and process in a variable phonology. 1979. Dissertation, University of Pennsylvania, Pennsylvania.

The notion of the plural in Puerto Rico Spanish: competing constraints on /s/ deletion. In: LABOV, William (ed.) Locating language in time and space. Philadelphia: University of Pennsylvania, 1980. p. 55-67.

Variation theory and language contact. American Dialect Research. Amsterdam; Philadelphia: John Benjamins Publishing, 1993.

RAE. Diccionario de la lengua, espanhola. Disponível em: <http://www.rae.es/recursos/diccionarios/drae>. Acesso em: 1 jun. 2014.

RAMOS, Conceição Maria de Araujo; BEZERRA, José Ribamar Mendes; ROCHA, Maria de Fátima Sopas. Do nosso cotidiano ou do cotidiano da gente? Um estudo da alternância nós/a gente no português do Maranhão. SIGNUM, Londrina, v. 12, n. 1, p. 279-292, jul. 2009.

RATINHO, Maria Filipe Mariano. Monte Gordo - Estudo etnográfico $e$ linguístico. Dissertação (Licenciatura em Filologia Românica) - Faculdade de Letras, Universidade de Lisboa, Lisboa, 1959.

RICHARDS, J. C.; PLAT, J; PLAT, H. Diccionario de linguística aplicada y enseñanza de lenguas. (Versión española de Carmen Muñoz Lahoz y Carmen Pérez Vidal). Barcelona: Ariel, 1997. 
RONA, José Pedro. El dialecto "fronterizo" del norte del Uruguay. Montevideo: Adolfo Linardi. 1965.

La frontera linguística entre el portugués y el español en el norte del Uruguay. Veritas, v. 8, n. 2, p. 201-221, 1963.

RUBIO, Cássio Florêncio. Padrões de concordância verbal e de alternância pronominal no português brasileiro e europeu: estudo sociolinguístico comparativo. 2012. Tese (Doutorado em Estudos Linguísticos) - Instituto de Biociências, Letras e Ciências Exatas, Universidade Estadual Paulista, São José do Rio Preto.

SAMPAIO, Adilma; LOPES, Lucélia Lima. O uso de "nós" e "a gente”, em função de sujeito, na comunidade rural de Piabas. 2009. Disponível em: http://www.uefs.br/colplet/revista/ed01_102009/artigos/artigo_07.pdf. Acesso em: 07 set. 2014.

SANKOFF, David; TAGLIAMONTE, Sali A.; SMITH, E. Goldvarb X - A multivariate analysis application. Toronto: Department of Linguistics; Ottawa: Department of Mathematics, 2005. Disponível em: <http://individual.utoronto.ca/tagliamonte/ Goldvarb/GV_index.htm\#ref>. Acesso em: 15 jan. 2010

SANKOFF, David. Variables Rules. In: AMMON, U.; DITTMAR, N.; MATTHEIER, K. J. (Eds.). Sociolinguistics. New York: Academic Press, 1988a p. 119-127.

Sociolinguistics and syntactic variation. In: NEWMEYER, Frederick J. (Ed.) Linguistics: the Cambridge survey. v. 4 (Language: the socio-cultural context), New York: Cambridge University Press, 1988b. p.141-160.

SANTOS, N. V.; COSTA, E. D.; SILVA, F. A. O uso do "nós" e do "a gente" na escrita de estudantes universitários. V Fórum Identidades e Alteridades. I Congresso Nacional Educação e Diversidade. UFS - Itabaiana/SE, 2011.

SCHERER, Amanda E; MORALES, Gladys; LECLERQ, Hélène. Palavras de intervalo no decorrer da vida ou por uma política imaginária da identidade e da linguagem. In: CORACINI, Maria José. Identidade \& discurso: (des)construindo subjetividades. Campinas: Ed. UNICAMP; Chapecó: Argos Editora Universitária, 2003. p. 23-35.

SCHERRE, Maria Marta Pereira. Paralelismo linguístico. Revista Estudos da Linguagem, Belo Horizonte, v. 7, p. 29-59, 1998.

. Reanálise da Concordância Nominal em Português. 1988. Tese (Doutorado em $\mathrm{xx}$ ) - UFRJ, Rio de Janeiro.

Speech Community. In: BROWN, Keith (Ed.). Encyclopedia of Language \& Linguistics. v. 11. 2. ed. Oxford: Elsevier, 2006. p. 716-722.

SCHERRE, Maria Marta Pereira; NARO, Anthony Julius. Origens do português brasileiro. São Paulo: Parábola, 2007.

Sociolinguistic correlates of negative evaluation: Variable concord in Rio de Janeiro. Language Variation and Change, Cambridge University Press, n. 26, p. 1-27, 2014. 
SCHERRE, Maria Marta Pereira, YACOVENCO, Lilian Coutinho. A variação linguística e o papel dos fatores sociais: o gênero do falante em foco. Revista da ABRALIN, v. eletrônico, n. especial, $1^{\mathrm{a}}$ parte, p. 121-146, 2011. Disponível em: http://www.abralin.org/revista/RVE1/v14.pdf. Acesso em: 25 set. 2014.

SEARA, Izabel Christine. A variação do sujeito nós e a gente na fala florianopolitana. Organon, UFRGS, v. 14, n. 28-29, 2000. p. 179-194.

SELINKER, L. La interlengua. In: LICERAS, Juana Muñoz. La adquisición de las lenguas extranjeras. Visor Lingüística y Conocimiento. Madrid: Editora, 1992. p. 79101. Traducción de "Interlanguage". Intrernational Review of Applied Linguistics, 10, 1972. p. 209-23.

. Language Transfer. General linguistics, v. 9, 1969. p. 67-92.

SILVA, Caio Cesar Castro da. A variação nós $e$ a gente no português culto carioca. Revista do GELNE, Piauí, v. 12, n. 1, 2010.

SILVA-CORVALÁN, Carmen. Exploring Internal Motivation for Change. In:

Language contact and change: Spanish in Los Angeles. Oxford: Clarendon Press; New York: Oxford University Press, 1994. p. 92-121.

SILVA, Ivanilde. De quem nós/a gente está(mos) falando afinal? Uma investigação sincrônica da variação entre nós e a gente como estratégias de designação referencial. Dissertação (Mestrado em Linguística) - Universidade Federal de Santa Catarina, Florianópolis, 2004.

SILVA, Rosalina Carvalho. A falsa dicotomia qualitativo-quantitativo: paradigmas que informam nossas práticas de pesquisa. In: ROMANELLI, G.; BIASOLI-ALVES, Z. M. M. Diálogos Metodológicos sobre Prática de Pesquisa - Programa de Pós-Graduação em Psicologia da FFCLRP USP / CAPES ; Rio Preto: Editora Legis-Summa, 1998.

SILVA, Vera Lúcia Paredes da. Relevância das variáveis linguísticas. In: MOLLICA, Maria Cecília; BRAGA, Maria Luiza (Orgs.) Introdução à sociolinguística: o tratamento da variação. São Paulo: Contexto, 2004. p. 67-71.

SOARES, Carolina Noémia Abranches de Sousa. Sangue Negro. Maputo: Associação dos Escritores Moçambicanos, 2001. p. 136-137.

SPINASSÉ, K. P. Os conceitos de língua materna, segunda língua e língua estrangeira e os falantes de línguas alóctones minoritárias no sul do Brasil. In: Revista contingentia, v. 1, n. 1, 2006. p 01-10.

STURZA, Eliana Rosa. Línguas de fronteira: o desconhecido território das práticas linguísticas nas fronteiras brasileiras. Ciência e cultura, São Paulo, vol. 57, n. 2, São Paulo, 2005.

TAGLIAMONTE, Sali. A. Analysing sociolinguistic variation. New York: Cambridge University Press, 2006. 
TAMANINE, Andréa Maristela Bauer. A alternância nós/ a gente no interior de Santa Catarina. 2002. Dissertação (Mestrado em Letras). Universidade Federal do Paraná, Curitiba.

Análise da alternância pronominal nós/ a gente na fala urbana dos sãobentenses. UNIVILLE, Anais do $6^{\circ}$ Encontro Celsul - Círculo de Estudos Lingüísticos do Sul, 2004.

TARALLO, Fernando. A pesquisa sociolinguística. Editora Ática, 2004.

TARONE, E. On the variability of interlanguage systems. Applied Linguistics, vol. 4, n. 2, 1983. p. 142-164.

TEYSSIER, Paul. História da Língua Portuguesa. Tradução Celso Cunha. $2^{\mathrm{a}}$ ed. São Paulo: Martins Fontes, 2001.

THOMASON, Sarah G. Social and linguistic factors as predictors of contact-induced change. Journal of language contact. Disponível em: THEMA 2. www. jlc-journal.org. 2008. Acesso em: 15 jan. 2014.

TRINDADE, Iole Faviero. A formação da identidade nacional nas páginas das cartilhas. In: LOPES, Luiz Paulo da Moita e BASTOS, Liliana Cabral. Identidades: recortes multi e interdisciplinares. Mercado das Letras, São Paulo: Campinas, 2002. p. 233-254.

UYENO, Elzira Yoko. Determinações identitárias do bilinguismo: a eterna promessa da língua materna. In: CORACINI, Maria José. Identidade \& discurso: (des)construindo subjetividades. Campinas: Editora da UNICAMP; Chapecó: Argos Editora Universitária, 2003. p. 83-118.

VIANNA, J. B. S. Semelhanças e diferenças na implementação de a gente em variedades do português. 2011 Tese (Doutorado em Letras Vernáculas). Faculdade de Letras, Universidade Federal do Rio de Janeiro, 2011.

VIANNA, J. B. S; LOPES, C. R. S. Implementação de a gente nas funções de acusativo, dativo e oblíquo: reflexões, propostas e primeiros resultados. Lingüística, vol. 29 (1), 2013. p. 11-36.

WALTERMIRE, Mark. Social and Linguistic Correlates of Spanish-Portuguese Bilingualism on the Uruguayan-Brazilian Border. The University of New México, Albuquerque, New Mexico, 2006.

. The differential use of Spanish and Portuguese along the UruguayanBrazilian border. International Journal of Bilingual Education and Bilingualism, v. 15, n.5, 2012. p. 509-531.

WEINREICH, U; LABOV, W; HERZOG, M. Fundamentos empíricos para uma teoria da mudança linguística. (Trad. Marcos Bagno). São Paulo: Parábola Editorial, 2006 [1968].

WEINREICH, Uriel. Languages in contact. Haia: Mounton, 1953. 
WOODWARD, K. (Org.). Identity and difference: culture, media and identities. London: Sage, 1997.

WOOLARD, Kathryn. Codeswitching. In: MALDEN, A. Duranti (Ed.) A Companion to Linguistic Anthropology. Oxford, UK: Blackwell Publishing, 2006. p. 72-94.

YACOVENCO, Lilian Coutinho e SCHERRE, Maria Marta Pereira. A variação linguística, o gênero do falante e o princípio de marcação linguística e social. In: CARMELINO, A. C; MEIRELES, A. R; YACOVENCO. Questões linguísticas: diferentes abordagens teóricas. Vitória: PPGEL/UFES, 2012. p. 173-190.

ZILLES, Ana Maria S. Grammaticalization of a gente as a cluster of changes: evidence from apparent and real time studies. Fórum Lingüístico, Florianópolis, v. 4, n.1, 2004. p 13-46.

O que a fala e a escrita nos dizem sobre a avaliação social do uso de a gente? UNISINOS/UFRGS. Letras de Hoje, Porto Alegre, v. 42, n. 2, 2007. p. 27-44.

$\underline{\text { Documentos sem referência ou sem data }}$

El País, Uruguay y sus 19 departamentos (s/d, pp. 11-12).

Engenheiro Agrônomo Julio Cezar Vinholes Pinto (s/d).

FACCIO, Liane. Prefeito de Bagé luta para não perder Colônia Nova. (s/d)

Lei de 9 de julho de 1862, Art. 1.

Municipio Acegua. $1^{\circ}$ de Enero del 2001.

Ricardo Garcia (s/d).

Relato de una vida empresarial (s/d).

TADÊO, Ricardo Williams Garcia. Aceguá - Yaciguay. (elaboração e pesquisa) (s/d).

Documentos regionais ou históricos

ACEGUÁ. 14 anos de emancipação. 10 anos de instalação. Informe comercial, 28 de abril de 2010.

ACEVEDO, Eduardo. Ley n $n^{\circ} 765$ - “Juncal”. Sala de Senado, Montevideo 17 de abril de 1863.

LENGUAS, Nicolás. Proyecto de Ley. Montevideo, julio 9 de 1862. 
LUCAS, Márcia Rodrigues e ZUGE, Tassiane Einhardt. Município de Aceguá. In: Aceguá. 14 anos de emancipação. 10 anos de instalação. Informe comercial, 28 de abril de 2010.

MORELLI, Juan B. Ley no 10,101. "Pueblo Aceguá", 1941.

PEDEMONTE, Juan Carlos. Assembléia Geral. Diario El País, 1985.

SIAB. Sistema de Informação de atenção básica. 2009.

TARIGO, Enrique. Ley 15.810. Pueblo Aceguá. 1986.

$\underline{\text { Sites }}$

http://www.terragaucha.com.br/imags_acegua.htm. Acesso em: 25 fev. 12.

http://www.acegua.rs.gov.br/portal1/intro.asp?iIdMun=100143468. Acesso em: 25 fev. 12.

http://www.acegua.rs.gov.br/portal1/intro.asp?iIdMun=100143468. Acesso em: 25 fev. 12.

http://www.turismoenuruguay.com.uy/informacion_turistica/informacion_turistica_mas info.php?id=143\&secc=informacion_turistica. Acesso em: 27 fev. 12.

http://www.acegua.rs.gov.br/portal1/municipio/historia.asp?iIdMun=100143468.

Acesso em: 25 fev. 12.

http://www.brasil.org.uy/br/home/home/index.php?menu=sub1_7\&t=secciones\&secc=4 21. Acesso em: 02 mar. 12.

http://monergismo.com/raniere/anabatismo-o-movimento-mais-radical-e-maisperseguido-da-reforma-protestante/. Acesso em: 29 dez. 12. 


\section{APÊNDICE I}

\section{TERMO DE CONSENTIMENTO LIVRE E ESCLARECIDO (TCLE)}

Eu sou Cíntia da Silva Pacheco, estudante da Universidade de Brasília, e trabalho sob a orientação do Professora. Dra. Maria Marta Pereira Scherre, em uma pesquisa de doutorado denominada $O$ português fronteiriço de Aceguá: Fronteira Brasil-Uruguai.

O objetivo desta pesquisa é coletar e reunir informações sobre o contexto histórico e geográfico da fronteira Aceguá, bem como os aspectos linguísticos inerentes ao "portunhol" da fronteira. Portanto, preciso gravar entrevistas com os aceguaenses para obtenção dessas informações, além de observar e acompanhar diversas situações de interação cotidiana entre os morados de Aceguá. Para isso, as entrevistas terão duração de, no máximo, uma hora.

Você é o nosso convidado para participar dessa pesquisa, e sua participação é voluntária, não obrigatória. A qualquer momento, você pode desistir de participar e retirar seu consentimento. Portanto, não há riscos envolvidos para os participantes da pesquisa.

Essa pesquisa poderá beneficiar os colaboradores da seguinte maneira: (i) compilado histórico e linguístico, ainda inexistente na região de Aceguá; (ii) divulgação dos resultados na biblioteca de Aceguá; (iii) divulgação nacional e internacional da comunidade aceguaense; (iv) conhecimento aprofundado e científico do seu falar local (v) utilização dos resultados da pesquisa nas escolas da comunidade para o ensino de português e espanhol, etc.

As informações obtidas por meio dessa pesquisa serão confidenciais, e será mantido sigilo sobre sua participação e sua identificação (sua identidade não será divulgada em nenhuma hipótese).

Você receberá uma cópia deste termo caso aceite nos ajudar fornecendo o seu ponto de vista e se quiser entrar em contato comigo meus dados seguem abaixo. 
Pesquisadora: Cíntia da Silva Pacheco

(61) 81376795

cintialetras@yahoo.com.br

Declaro que entendi os objetivos de minha participação na pesquisa e concordo em participar.

Colaborador da pesquisa (ou responsável)

Para maiores esclarecimentos, o comitê de ética (CEP-IH), que rege as pesquisas do Instituto de Ciências Humanas, pode ser acionado pelo e-mail cep_ih@unb.br 


\section{ANEXO I}

\section{APROVAÇÃO DO COMITÊ DE ÉTICA}

\section{ANÁLSE DEPROJETO DEPESOUUSA}

Título do Projeto: PADRÕES LINGUísticos E SOCIAIS DO PORTUGUÊS FRONTEIRIÇO DE ACEGUÁ: FRONTEIRA BRASIL-URUGUAI

Pesquisador responsável: CÍNTIA DA SILVA PACHECO

Com base nas Resoluções 196/96, do CNS/MS, que regulamenta a ética da pesquisa em seres humanos, o Comitê de Ética em Pesquisa com Seres Humanos do Instituto de Ciências Humanas da Universidade de Brasília, após análise dos aspectos éticos, resolveu APROVAR o projeto intitulado "PADRÕES LINGUísTICOS E SOCIAIS DO PORTUGUÊS FRONTEIRIÇO DE ACEGUÁ: FRONTEIRA BRASIL-URUGUAI".

O pesquisador responsável fica notificado da obrigatoriedade da apresentação de um relatório final sucinto e objetivo sobre o desenvolvimento do Projeto, no prazo de 1 (um) ano a contar da presente data (itens VII.13 letra "d" e IX.2 letra "c" da Resolução CNS 196/96).

Brasilia, 18 de julho de 2011

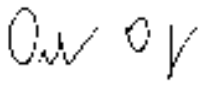

Debora Diniz Coordenadora Geral - CEP/IH 